Prepared in cooperation with the Bureau of Reclamation

\title{
Hydrologic Setting and Conceptual Hydrologic Model of the Walker River Basin, West-Central Nevada
}

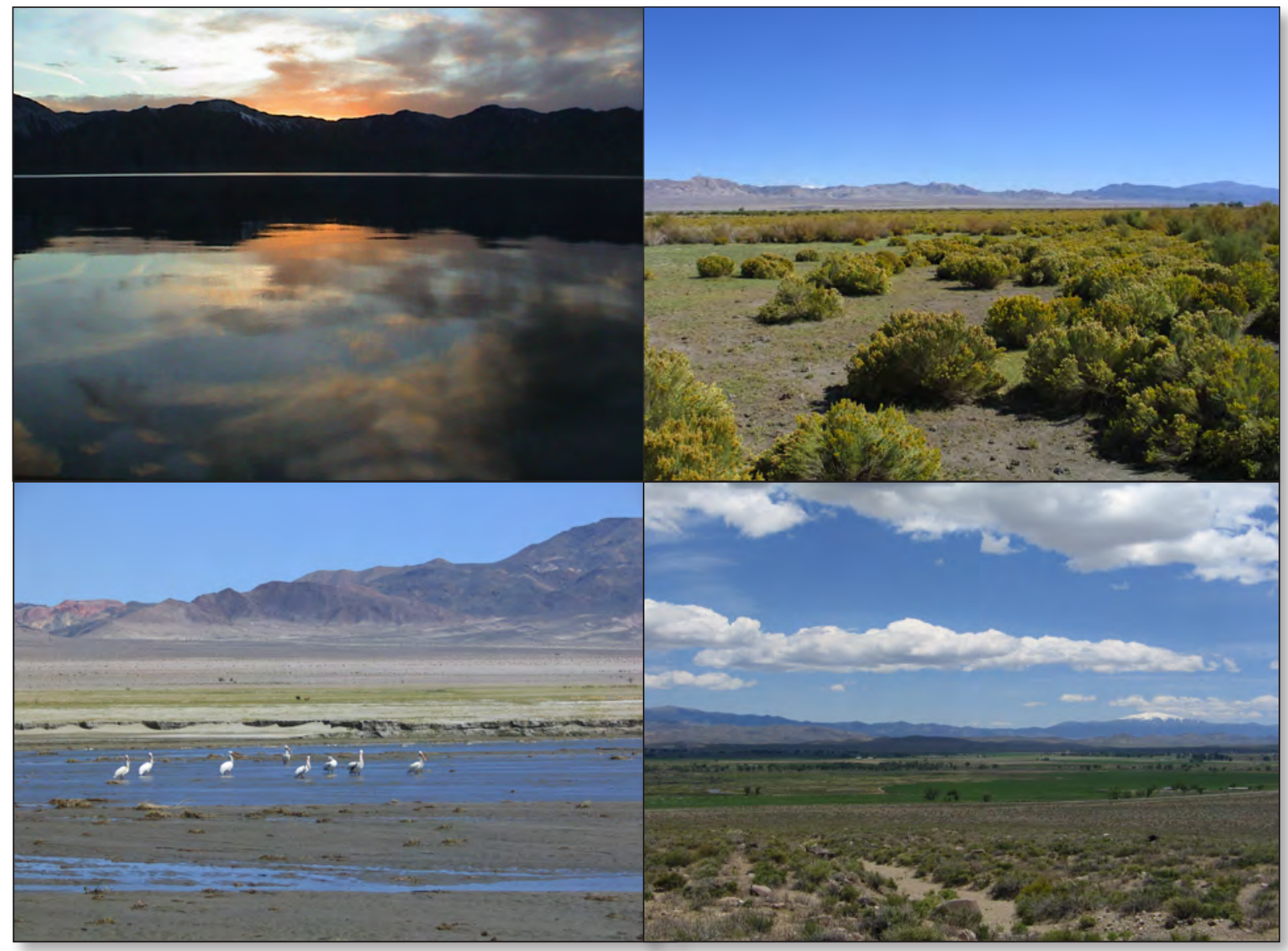

Scientific Investigations Report 2009-5155 
Cover:

Upper left: Walker Lake at sunset (photograph by Thomas J. Lopes, March 3, 2005)

Upper right: Rabbitbrush in bloom south of Schurz, Nevada (photograph by Thomas J. Lopes, September 28, 2004)

Lower left: White pelicans at the mouth of the Walker River (photograph by Thomas J. Lopes, April 23, 2004)

Lower right: Southern Mason Valley and white-capped Mount Grant in the distance (photograph by Thomas J. Lopes, June 3, 2008) 


\section{Hydrologic Setting and Conceptual Hydrologic Model of the Walker River Basin, West-Central Nevada}

By Thomas J. Lopes and Kip K. Allander

Prepared in cooperation with the Bureau of Reclamation

Scientific Investigations Report 2009-5155 


\title{
U.S. Department of the Interior \\ KEN SALAZAR, Secretary \\ U.S. Geological Survey \\ Suzette M. Kimball, Acting Director
}

\section{U.S. Geological Survey, Reston, Virginia: 2009}

\author{
For more information on the USGS - the Federal source for science about the Earth, its natural and living resources, \\ natural hazards, and the environment, visit http://www.usgs.gov or call 1-888-ASK-USGS \\ For an overview of USGS information products, including maps, imagery, and publications, \\ visit http://www.usgs.gov/pubprod \\ To order this and other USGS information products, visit http://store.usgs.gov
}

\begin{abstract}
Any use of trade, product, or firm names is for descriptive purposes only and does not imply endorsement by the U.S. Government.

Although this report is in the public domain, permission must be secured from the individual copyright owners to reproduce any copyrighted materials contained within this report.
\end{abstract}

Suggested citation:

Lopes, T.J., and Allander, K.K., 2009, Hydrologic setting and conceptual hydrologic model of the Walker River basin, west-central Nevada: U.S. Geological Survey Scientific Investigations Report 2009-5155, 84 p. 


\section{Contents}

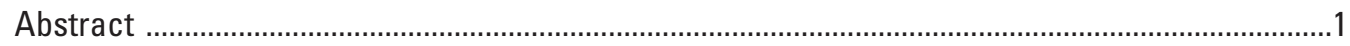

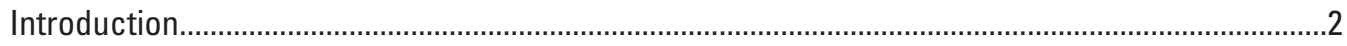

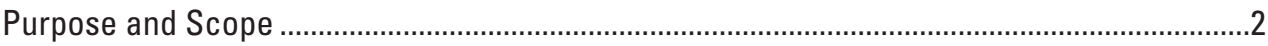

Description of the Walker River Basin ...................................................................................

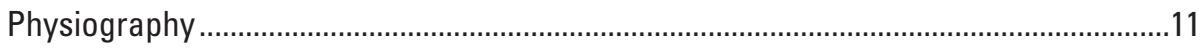

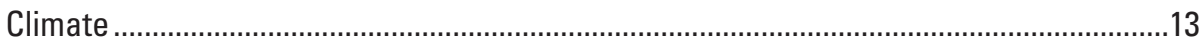

Natural and Agricultural Vegetation .......................................................................16

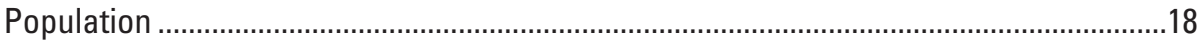

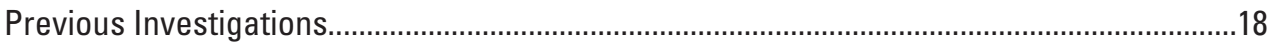

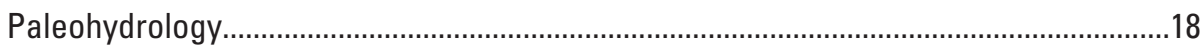

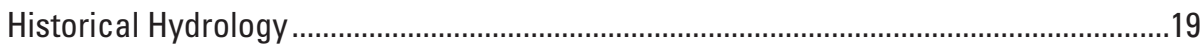

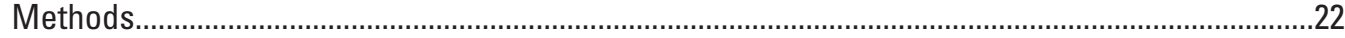

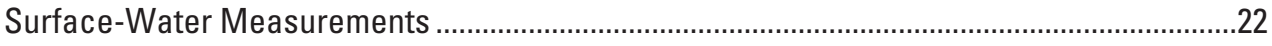

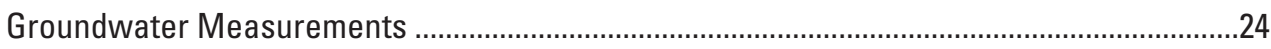

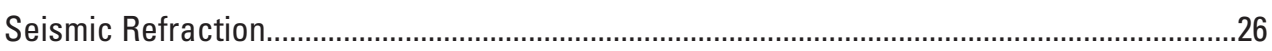

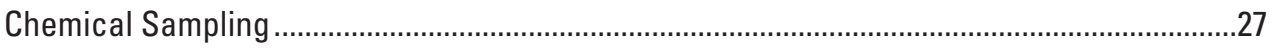

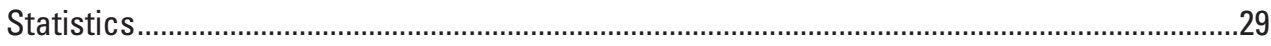

Hydrologic Setting of the Lower Walker River Basin ..................................................................29

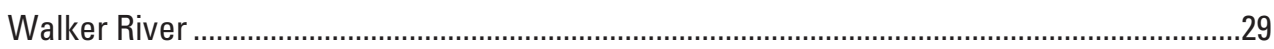

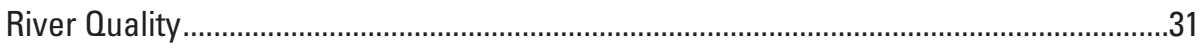

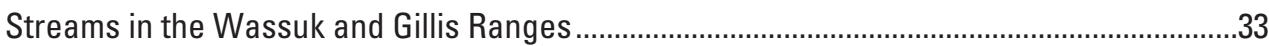

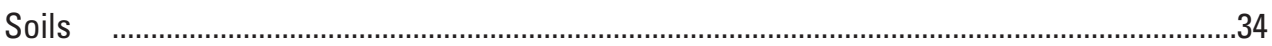

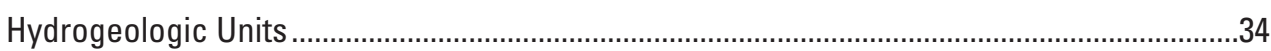

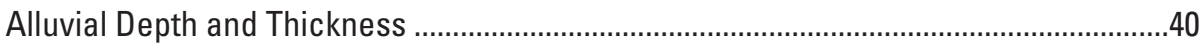

Hydraulic Properties ........................................................................................................... 48

Subsurface-Flow Estimates .......................................................................................... 49

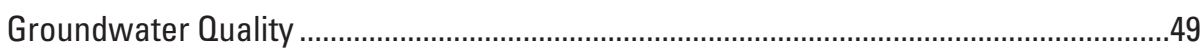

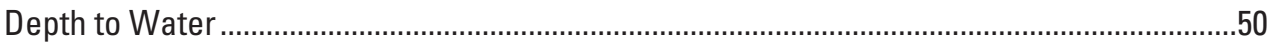

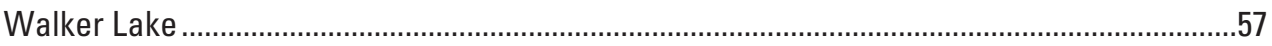

Conceptual Hydrologic Model of the Walker River Basin ...............................................................55

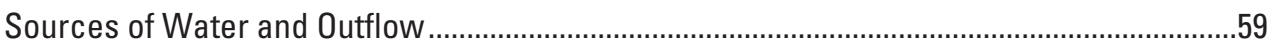

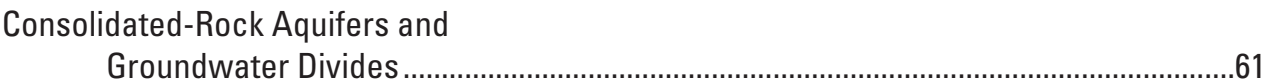

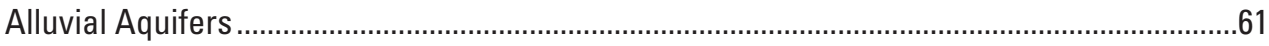

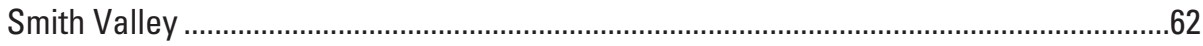

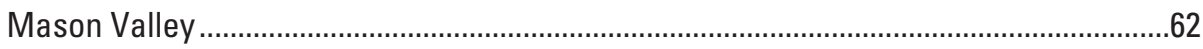

Wabuska to Little Dam .......................................................................................................64

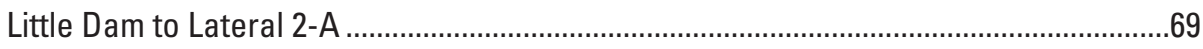

Lateral 2-A to Walker Lake................................................................................................. 72

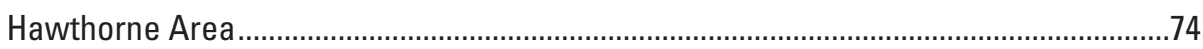

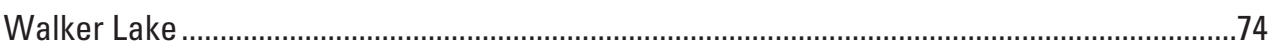

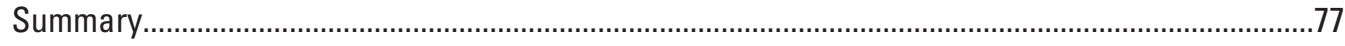

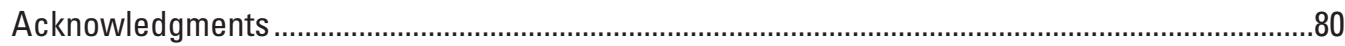

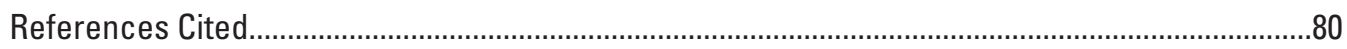




\section{Plate}

Plate 1. Map showing water-table contours in Smith Valley, Mason Valley, and lower Walker River basin, autumn 2006.

\section{Figures}

Figure 1. Map showing locations of selected features in the Walker River basin, California and Nevada

Figure 2. Photograph of view looking north from the southern end of Walker Lake, Nevada 4

Figure 3. Graph showing lake-surface altitude and dissolved-solids concentrations of Walker Lake, Nevada, from 1882 through September 30, 2008

Figure 4. Photograph of view looking upstream at the streamflow-gaging station Walker River near Wabuska, Nevada

Figure 5. Photograph of Bridgeport valley, California, looking south from Highway 395 towards Twin Lakes and 12,000-foot peaks of the Sierra Nevada

Figure 6. Photograph of view looking south at Topaz Lake on the West Fork of the Walker River, the upper Antelope Valley, and the snowcapped Sweetwater Range, Nevada and California

Figure 7. Photograph of view looking southwest at Bridgeport Reservoir, California, on the East Fork of the Walker River, and the Sierra Nevada.

Figure 8. Photograph of alfalfa field in Antelope Valley, Nevada and California, with the Sweetwater Range in the background

Figure 9. Photograph of view looking southwest from Parker Butte at the Mason Valley Wildlife Management Area, Nevada

Figure 10. Photograph of cottonwood trees along the Walker River just downstream from the Mason Valley Wildlife Management Area, Nevada

Figure 11. Photograph of riparian vegetation along the Walker River between the Wabuska gaging station and Weber Reservoir, Nevada

Figure 12. Photograph of the spillway at the repaired Weber Dam, Nevada ................. 10

Figure 13. Photograph of view looking south at Walker Lake from the mouth of the Walker River, Nevada

Figure 14. Photograph of view from northeastern Smith Valley looking southwest towards Artesia Lake and the Pine Nut Range, Nevada

Figure 15. Photograph of view from Walker Lake looking southwest at Mount Grant, Nevada 12

Figure 16. Photograph of view from Walker Lake looking east at a thunderstorm over the Gillis Range, Nevada

Figure 17. Map showing distribution of precipitation in the Walker River basin, Nevada and California

Figure 18. Map showing the distribution of irrigated land in the Walker River basin, Nevada and California, during the 2000 growing season

Figure 19. Photograph showing sacks filled with onions during the 2006 autumn harvest, Pete Hendrichs Road, Mason Valley, Nevada

Figure 20. Graph showing lake-surface altitude of Mono Lake, California, and Walker Lake, Nevada, from 1850 through September 30, 2007

Figure 21. Map showing locations of selected surface-water sites in the Walker River basin, Nevada 


\section{Figures-Continued}

Figure 22. Map showing locations of selected wells in the Walker River basin, Nevada ..... 25

Figure 23. Map showing locations of seismic-refraction lines and generalized cross

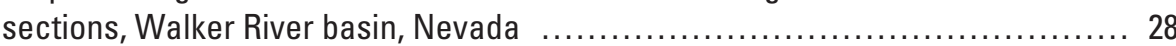

Figure 24. Graph showing mean daily discharge and accumulated volume of discharge for water years 1945 through 2007, Walker River near Wabuska, Nevada $\quad . . . . . .30$

Figure 25. Graph showing annual discharge at the Walker River near Wabuska, Nevada for water years 1903 through 2007

Figure 26. Graphs showing daily mean discharge at the Walker River above Little Dam near Schurz, Nevada, Walker River at Lateral 2-A siphon near Schurz, Nevada, Walker River near Mouth at Walker Lake, October 2004 through September 2007 and Little Dam and Lateral 2-A gaging stations, November 2004 through April 2005

Figure 27. Box plots showing ranges in specific conductance at streamflow-gaging stations in the Walker River basin, Nevada

Figure 28. Graph showing daily mean discharge from drainage basins in the Sierra Nevada and Wassuk and Toiyabe Ranges, May 2005 through September

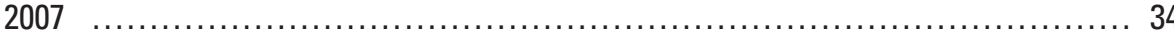

Figure 29. Map showing distribution of soil permeability in the lower Walker River basin, Nevada

Figure 30. Map showing distribution of hydrogeologic units in the Walker River basin, Nevada and California

Figure 31. Photograph showing lake clays overlain by fluvial sand and gravel in a road cut along Highway 95 about 1 mile north of Schurz, Nevada.

Figure 32. Photograph of alluvial fans along the eastern flank of the Wassuk Range about 4 miles south of Schurz, Nevada

Figure 33. Photograph of view looking southwest towards Mount Grant and an alluvial fan about 2 miles north of Walker Lake, Nevada, that has been reworked into beach deposits

Figure 34. Photograph of view looking east towards the Double Spring well and playa, Walker River basin, Nevada

Figure 35. Graphs showing depth to bedrock and thickness of alluvial strata along seismic-refraction lines Double Spring Line 1, Double Spring Line 3, and Double Spring Line 4, Walker River basin, Nevada

Figure 36. Graphs showing depth to bedrock and thickness of alluvial strata along seismic-refraction lines (A) Line 1 and (B) Line 2 on the Hawthorne Army Ammunition Depot (HAAD), Nevada

Figure 37. Generalized cross section of the Double Spring, Nevada, area $\ldots \ldots \ldots \ldots \ldots \ldots .46$

Figure 39. Generalized cross section of tThe area north of Walker Lake, Nevada .......... 47

Figure 38. Generalized cross section of the area south of Walker Lake, Nevada ............ 47

Figure 40. Map showing depth to water in Smith and Mason Valleys, and the lower Walker River basin, Nevada

Figure 41. Box plots showing change in depth to water in Smith and Mason Valleys, Nevada, following the 2005 and 2006 irrigation seasons 


\section{Figures-Continued}

Figure 42. Graph showing groundwater pumpage in Smith and Mason Valleys compared with streamflow of the Walker River near Wabuska, Nevada

Figure 43. Graphs showing time series of depth to water in Smith and Mason Valleys and the Hawthorne area, Nevada

Figure 44. Map showing locations of wells with either declining or stable water levels in Smith and Mason Valleys, Nevada

Figure 45. Map showing locations of core sites and mounds or anomalies detected using single-beam sonar, Walker Lake, Nevada 58

Figure 46. Graph showing oxygen and hydrogen isotopes in groundwater and surface water from the lower Walker River basin, Nevada

Figure 47. Diagrams showing groundwater levels at the Willow and Cow Camp sites, Walker River basin, Nevada

Figure 48. Photograph of groundwater seeping into a shallow drainage just downstream from the Cow Camp gaging station, Walker River basin, Nevada..... 65

Figure 49. Graphs showing radon, stream discharge, and dissolved solids in streamflow and groundwater along the Walker River between Wabuska and Cow Camp, Nevada

Figure 50. Graph showing altitude of groundwater adjacent to Weber Reservoir, Nevada, and reservoir elevation, October 1, 2004, through June 1, 2008

Figure 51. Photograph of lake sediments exposed in a drainage about 0.5 mile south of the Walker River near Parker Butte, Nevada

Figure 52. Piper diagram showing proportions of major ions in groundwater and streamflow from the Wabuska gaging station to the Cow Camp gaging station, Walker River basin, Nevada

Figure 53. Graphs showing mean daily discharge at theWabuska gaging station and difference in mean daily discharge between the Cow Camp and Wabuska gaging stations, Walker River basin, Nevada, October 1, 1999, through September 30, 2004

Figure 54. Graphs showing depth to water and (B) groundwater temperature at the Willow site and stream discharge at the Cow Camp gaging station, Walker River basin, Nevada

Figure 55. Graph showing depth to water at the Willow, Lateral 2-A, and Powerline sites and stream discharge at the Lateral 2-A gaging station, Walker River basin, Nevada, May 1, 2005, through September 30, 2007

Figure 56. Graph showing streamflow at Walker River above Little Dam near Schurz, Nevada, and difference in accumulated volume of streamflow between Little Dam and Lateral 2-A gaging stations, Walker River basin, Nevada, October 1, 2004, through September 30, 2008

Figure 57. Graphs showing groundwater altitudes at the Schurz NE wells and Transmission Line and East Lake wells, Walker River basin, Nevada, March 1, 2007, through March 1, 2008

Figure 58. Graph showing difference in accumulated volume of streamflow between the Lateral 2-A and the near Mouth gaging stations and stream discharge at the 


\section{Figures-Continued}

Lateral 2-A gage, Walker River basin, Nevada, October 1, 2004, through May 16, 2006 73

Figure 59. Graph showing depth to water at the Powerline site and stream discharge at the Lateral 2-A gaging station, Walker River basin, Nevada, May 1, 2005, through October

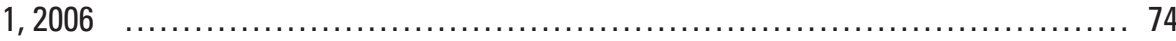

Figure 60. Photograph of view from the Wassuk Range looking southeast at the riparian area

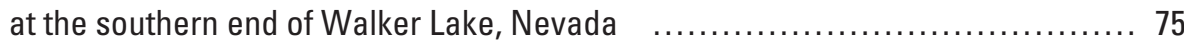

Figure 61. Graphs showing deuterium compared with $\delta^{18} 0$ for all samples from Walker Lake, the Walker River, and nearby groundwater and selected pore-water, lake-bottom, and mid-depth samples from Walker Lake, Nevada .......................... 76

Figure 62. Graphs showing depth compared with $\delta^{18} 0$ in pore water for shallow and deep core samples and shallow core samples, Walker Lake, Nevada

\section{Tables}

Table 1. Precipitation and temperature normals at weather stations in the Walker River basin, Nevada and California, 1971-2000....

Table 2. Precipitation volumes for hydrographic areas in the Walker River basin, Nevada and California. 14

Table 3. Altitude of Walker Lake, Nevada, from 1845 to 1928

Table 4. Streamflow and diversion gaging stations in the lower Walker River basin, Nevada. 30

Table 5. Results of slug tests from the lower Walker River basin, Nevada. .............. 48

Table 6. Initial and latest water-level data for selected wells near Schurz, Nevada. ........ 57

Table 7. Discharge data from Walker River basin, Nevada, November 28, 2005. 


\title{
Conversion Factors and Datums
}

\author{
Conversion Factors
}

\begin{tabular}{|c|c|c|}
\hline Multiply & By & To obtain \\
\hline \multicolumn{3}{|c|}{ Length } \\
\hline inch (in.) & 2.54 & centimeter $(\mathrm{cm})$ \\
\hline inch (in.) & 25.4 & millimeter (mm) \\
\hline foot (ft) & 0.3048 & meter (m) \\
\hline mile (mi) & 1.609 & kilometer (km) \\
\hline \multicolumn{3}{|c|}{ Area } \\
\hline acre & 4,047 & square meter $\left(\mathrm{m}^{2}\right)$ \\
\hline acre & 0.4047 & hectare (ha) \\
\hline acre & 0.4047 & square hectometer $\left(\mathrm{hm}^{2}\right)$ \\
\hline acre & 0.004047 & square kilometer $\left(\mathrm{km}^{2}\right)$ \\
\hline square mile $\left(\mathrm{mi}^{2}\right)$ & 259.0 & hectare (ha) \\
\hline square mile $\left(\mathrm{mi}^{2}\right)$ & 2.590 & square kilometer $\left(\mathrm{km}^{2}\right)$ \\
\hline \multicolumn{3}{|c|}{ Volume } \\
\hline acre-foot (acre-ft) & 1,233 & cubic meter $\left(\mathrm{m}^{3}\right)$ \\
\hline acre-foot (acre-ft) & 0.001233 & cubic hectometer $\left(\mathrm{hm}^{3}\right)$ \\
\hline gallon (gal) & 3.785 & liter (L) \\
\hline ounce, fluid (fl. oz) & 0.02957 & liter (L) \\
\hline \multicolumn{3}{|c|}{ Flow rate } \\
\hline inch per year (in/yr) & 25.4 & millimeter per year (mm/yr) \\
\hline foot per second (ft/s) & 0.3048 & meter per second $(\mathrm{m} / \mathrm{s})$ \\
\hline foot per year (ft/yr) & 0.3048 & meter per year (m/yr) \\
\hline acre-foot per year (acre-ft/yr) & 1,233 & cubic meter per year $\left(\mathrm{m}^{3} / \mathrm{yr}\right)$ \\
\hline acre-foot per year (acre-ft/yr) & 0.001233 & cubic hectometer per year $\left(\mathrm{hm}^{3} / \mathrm{yr}\right)$ \\
\hline cubic foot per second $\left(\mathrm{ft}^{3} / \mathrm{s}\right)$ & 0.02832 & cubic meter per second $\left(\mathrm{m}^{3} / \mathrm{s}\right)$ \\
\hline mile per hour (mi/h) & 1.609 & kilometer per hour $(\mathrm{km} / \mathrm{h})$ \\
\hline gallon per minute (gal/min) & 0.06309 & liter per second $(\mathrm{L} / \mathrm{s})$ \\
\hline \multicolumn{3}{|c|}{ Mass } \\
\hline pound, avoirdupois (lb) & 0.4536 & kilogram $(\mathrm{kg})$ \\
\hline \multicolumn{3}{|c|}{ Radioactivity } \\
\hline picocurie per liter (pCi/L) & 0.037 & becquerel per liter $(\mathrm{Bq} / \mathrm{L})$ \\
\hline \multicolumn{3}{|c|}{ Hydraulic conductivity } \\
\hline foot per day (ft/d) & 0.3048 & meter per day $(\mathrm{m} / \mathrm{d})$ \\
\hline \multicolumn{3}{|c|}{ Transmissivity* } \\
\hline foot squared per day ( $\left.\mathrm{ft}^{2} / \mathrm{d}\right)$ & 0.09290 & meter squared per day $\left(\mathrm{m}^{2} / \mathrm{d}\right)$ \\
\hline
\end{tabular}




\section{Conversion Factors and Datums-Continued}

Temperature in degrees Celsius $\left({ }^{\circ} \mathrm{C}\right)$ may be converted to degrees Fahrenheit $\left({ }^{\circ} \mathrm{F}\right)$ as follows:

$$
{ }^{\circ} \mathrm{F}=\left(1.8 \times^{\circ} \mathrm{C}\right)+32
$$

Temperature in degrees Fahrenheit $\left({ }^{\circ} \mathrm{F}\right)$ may be converted to degrees Celsius $\left({ }^{\circ} \mathrm{C}\right)$ as follows:

$$
{ }^{\circ} \mathrm{C}=\left({ }^{\circ} \mathrm{F}-32\right) / 1.8
$$

*Transmissivity: The standard unit for transmissivity is cubic foot per day per square foot times foot of aquifer thickness $\left[\left(\mathrm{ft}^{3} / \mathrm{d}\right) / \mathrm{ft}^{2}\right] \mathrm{ft}$. In this report, the mathematically reduced form, foot squared per day $\left(\mathrm{ft}^{2} / \mathrm{d}\right)$, is used for convenience.

Specific conductance is given in microsiemens per centimeter at 25 degrees Celsius $(\mu \mathrm{S} / \mathrm{cm}$ at $\left.25^{\circ} \mathrm{C}\right)$.

Concentrations of chemical constituents in water are given either in milligrams per liter (mg/L) or micrograms per liter $(\mu \mathrm{g} / \mathrm{L})$.

Datums

Vertical coordinate information is referenced to the National Geodetic Vertical Datum of 1929 (NGVD 29).

Horizontal coordinate information is referenced to the North American Datum of 1927 (NAD 27). Altitude, as used in this report, refers to distance above the vertical datum. 
This page intentionally left blank. 


\title{
Hydrologic Setting and Conceptual Hydrologic Model of the Walker River Basin, West-Central Nevada
}

\author{
By Thomas J. Lopes and Kip K. Allander
}

\section{Abstract}

The Walker River is the main source of inflow to Walker Lake, a closed-basin lake in west-central Nevada. Between 1882 and 2008, agricultural diversions resulted in a lake-level decline of more than 150 feet and storage loss of 7,400,000 acre-ft. Evaporative concentration increased dissolved solids from 2,500 to 17,000 milligrams per liter. The increase in salinity threatens the survival of the Lahontan cutthroat trout, a native species listed as threatened under the Endangered Species Act. This report describes the hydrologic setting of the Walker River basin and a conceptual hydrologic model of the relations among streams, groundwater, and Walker Lake with emphasis on the lower Walker River basin from Wabuska to Hawthorne, Nevada.

The Walker River basin is about 3,950 square miles and straddles the California-Nevada border. Most streamflow originates as snowmelt in the Sierra Nevada. Spring runoff from the Sierra Nevada typically reaches its peak during late May to early June with as much as 2,800 cubic feet per second in the Walker River near Wabuska. Typically, 3 to 4 consecutive years of below average streamflow are followed by 1 or 2 years of average or above average streamflow.

Mountain ranges are comprised of consolidated rocks with low hydraulic conductivities, but consolidated rocks transmit water where fractured. Unconsolidated sediments include fluvial deposits along the active channel of the Walker River, valley floors, alluvial slopes, and a playa. Sand and gravel deposited by the Walker River likely are discontinuous strata throughout the valley floor. Thick clay strata likely were deposited in Pleistocene Lake Lahontan and are horizontally continuous, except where strata have been eroded by the Walker River. At Walker Lake, sediments mostly are clay interbedded with alluvial slope, fluvial, and deltaic deposits along the lake margins. Coarse sediments form a multilayered, confined-aquifer system that could extend several miles from the shoreline.
Depth to bedrock in the lower Walker River basin ranges from about 900 to 2,000 feet. The average hydraulic conductivity of the alluvial aquifer in the lower Walker River basin is 10-30 feet per day, except where comprised of fluvial sediments. Fluvial sediments along the Walker River have an average hydraulic conductivity of 70 feet per day. Subsurface flow was estimated to be 2,700 acre-feet per year through Double Spring. Subsurface discharge to Walker Lake was estimated to be 4,400 acre-feet per year from the south and 10,400 acre-feet per year from the north.

Groundwater levels and groundwater storage have declined steadily in most of Smith and Mason Valleys since 1960. Groundwater levels around Schurz, Nevada, have changed little during the past 50 years. In the Whisky Flat area south of Hawthorne, Nevada, agricultural and municipal pumpage has lowered groundwater levels since 1956. The water-level decline in Walker Lake since 1882 has caused the surrounding alluvial aquifer to drain and groundwater levels to decline.

The Wabuska streamflow-gaging station in northern Mason Valley demarcates the upper and lower Walker River basin. The hydrology of the lower Walker River basin is considerably different than the upper basin. The upper basin consists of valleys separated by consolidated-rock mountains. The alluvial aquifer in each valley thins or pinches out at the downstream end, forcing most groundwater to discharge along the river near where the river is gaged. The lower Walker River basin is one surface-water/groundwater system of losing and gaining reaches from Wabuska to Walker Lake, which makes determining stream losses and the direction and amount of subsurface flow difficult.

Isotopic data indicate surface water and groundwater in the lower Walker River basin are from two sources of precipitation that have evaporated. The Walker River, groundwater along the Wassuk Range, and Walker Lake plot along one evaporation line. Groundwater along the Gillis Range and Calico Hills plots along a different evaporation line that indicates more intense evaporation prior to recharge and that these are not significant sources of water to Walker Lake. 
Groundwater in alluvial aquifers generally flows downvalley with flow towards the river in gaining reaches and away from the river in losing reaches. The Walker River is mostly gaining in Smith Valley and losing in Mason Valley. In the lower Walker River basin, the river is losing for most of the reach between Wabuska and Cow Camp upstream from Weber Reservoir and gaining from Cow Camp to Little Dam about 2 miles downstream from Weber Reservoir. Even though most of the reach between Wabuska and Cow Camp is losing, infiltration seems to be small. Some infiltrated water flows north into Churchill Valley through the Wabuska lineament, a zone of northeast-trending faults.

The Walker River is losing for most of the reach between Little Dam and the Lateral 2-A streamflow-gaging stations. Stream infiltration and induced recharge in irrigated fields have created a groundwater divide that extends southeast from Schurz, Nevada. Groundwater south of the divide flows towards Walker Lake. Groundwater east of the divide flows towards Double Spring and out of the Walker River basin.

Most of the reach from Lateral 2-A to Walker Lake is gaining although streamflow can infiltrate along this reach. A maximum loss of 8,000 acre-feet per year was measured during the 2005 spring runoff which followed a 5-year drought. No additional losses were measured during 2006 even though there was continuous flow, indicating bank and aquifer storage had been filled.

Water-table contours and upward vertical gradients indicate Walker Lake is the final discharge point for groundwater in the lower Walker River basin.

\section{Introduction}

The Walker River basin is a topographically closed basin in west-central Nevada (fig. 1). All surface water drains toward Walker Lake, the lowest point in the basin and the terminus of the Walker River (fig. 2). The Walker River is the main source of inflow, but small tributaries from adjacent mountains and groundwater also discharge into Walker Lake (Everett and Rush, 1967; Schaefer, 1980). The only outflow from Walker Lake is evaporation from the lake surface. The Walker River has been diverted for irrigation in upstream valleys since the mid 1800s, which has reduced flow into Walker Lake
(Russell, 1885). Between 1882 and 2008, diversions resulted in a lake-level decline of more than $150 \mathrm{ft}$ and storage loss of 7,400,000 acre-ft. Evaporative concentration increased dissolved solids from 2,500 to $17,000 \mathrm{mg} / \mathrm{L}$ (fig. 3). The increase in salinity threatens the survival of the Lahontan cutthroat trout, a native species listed as threatened under the Endangered Species Act.

Section 2507 of Public Law 107-171 (2002 Farm Bill) provided $\$ 200,000,000$ to be used by the Secretary of Interior, acting through the Commissioner of Reclamation, to provide water to at-risk natural desert terminal lakes. This bill was later amended under Public Law 108-7, section 207, to include language "Restoration of fish, wildlife, and associated habitats in watersheds of certain lakes." The amendment specified that only Pyramid, Summit, and Walker Lakes in Nevada were to be considered under Section 2507, Public Law 107-171.

In response to the 2002 Farm Bill, the U.S. Geological Survey (USGS), in cooperation with the Bureau of Reclamation, began a study to refine the water budget for Walker Lake and to develop the capability to predict how changes in irrigation practices will affect flows in the lower Walker River. This is the fifth report from the study. Lopes (2005) described the objectives and tasks of the study, Lopes and Smith (2007) described the bathymetry of Walker Lake, Lopes and Medina (2007) estimated precipitation in westcentral Nevada including the Walker River basin, and Allander and others (2009) quantified evapotranspiration (ET) from the lake, and agricultural and native vegetation. The final report will describe the revised water budget for Walker Lake.

\section{Purpose and Scope}

This report describes the hydrologic setting of the Walker River basin and a conceptual hydrologic model of the relations among streams, groundwater, and Walker Lake. The report emphasizes the lower Walker River basin from the streamflowgaging station Walker River near Wabuska, Nev. (Wabuska gage, 10301500; fig. 4), to the Hawthorne Army Ammunition Depot (Army Depot) near Hawthorne, Nev. (fig. 1). Surfacewater/groundwater interactions and groundwater flow directions in Smith and Mason Valleys, the most agricultural part of the Walker River basin, also are described. Data were collected from 2004 through 2008. 


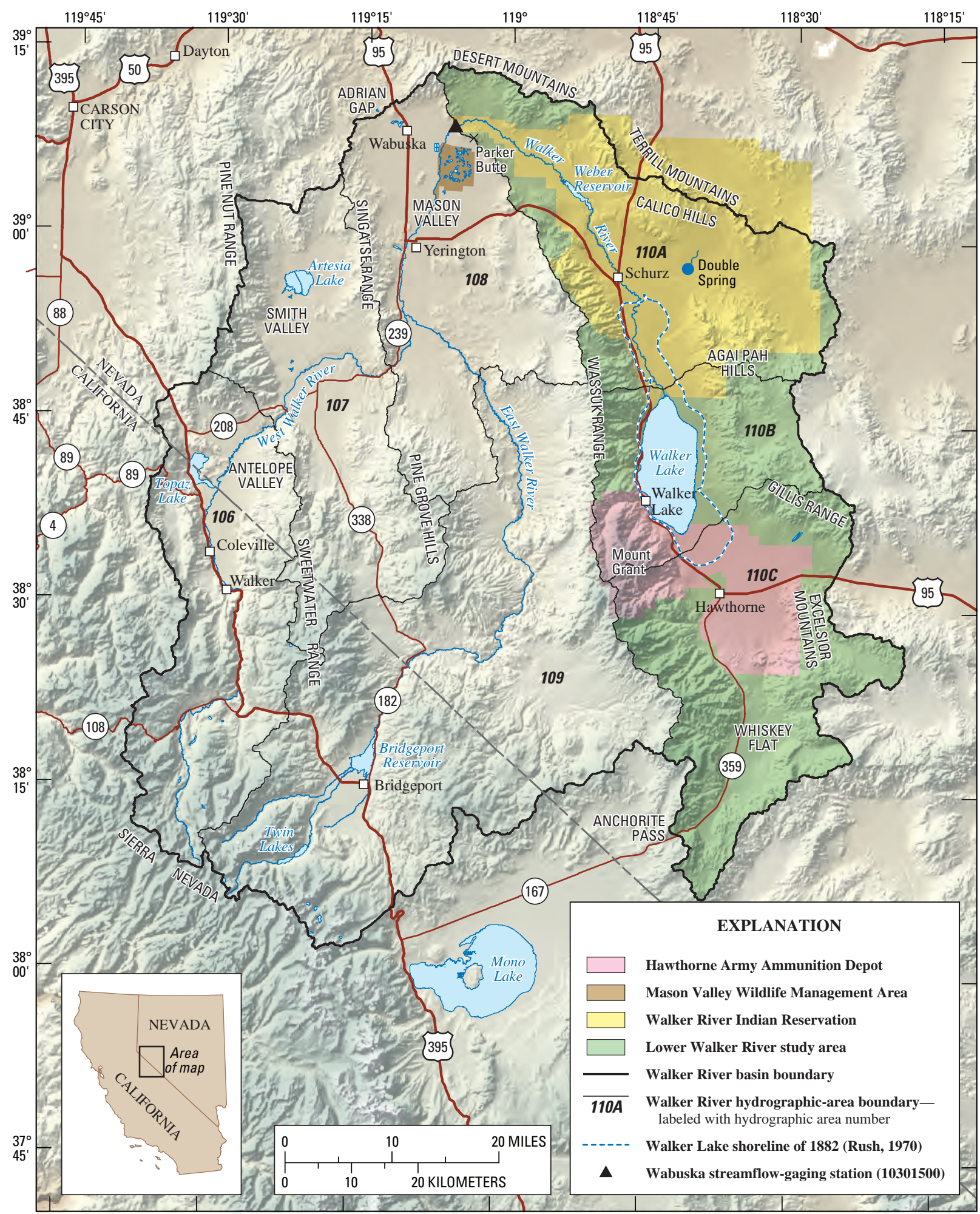

Base from U.S. Geological Survey digital data, 1:24,000 and 1:100,000, 1978-88. Walker Lake

average lake altitude of $3937.5 \mathrm{ft}$ for November 2006; Projection: Universal Transverse

Shuttle Radar Topography Mission digital data, 2000.

Figure 1. Locations of selected features in the Walker River basin, California and Nevada. 


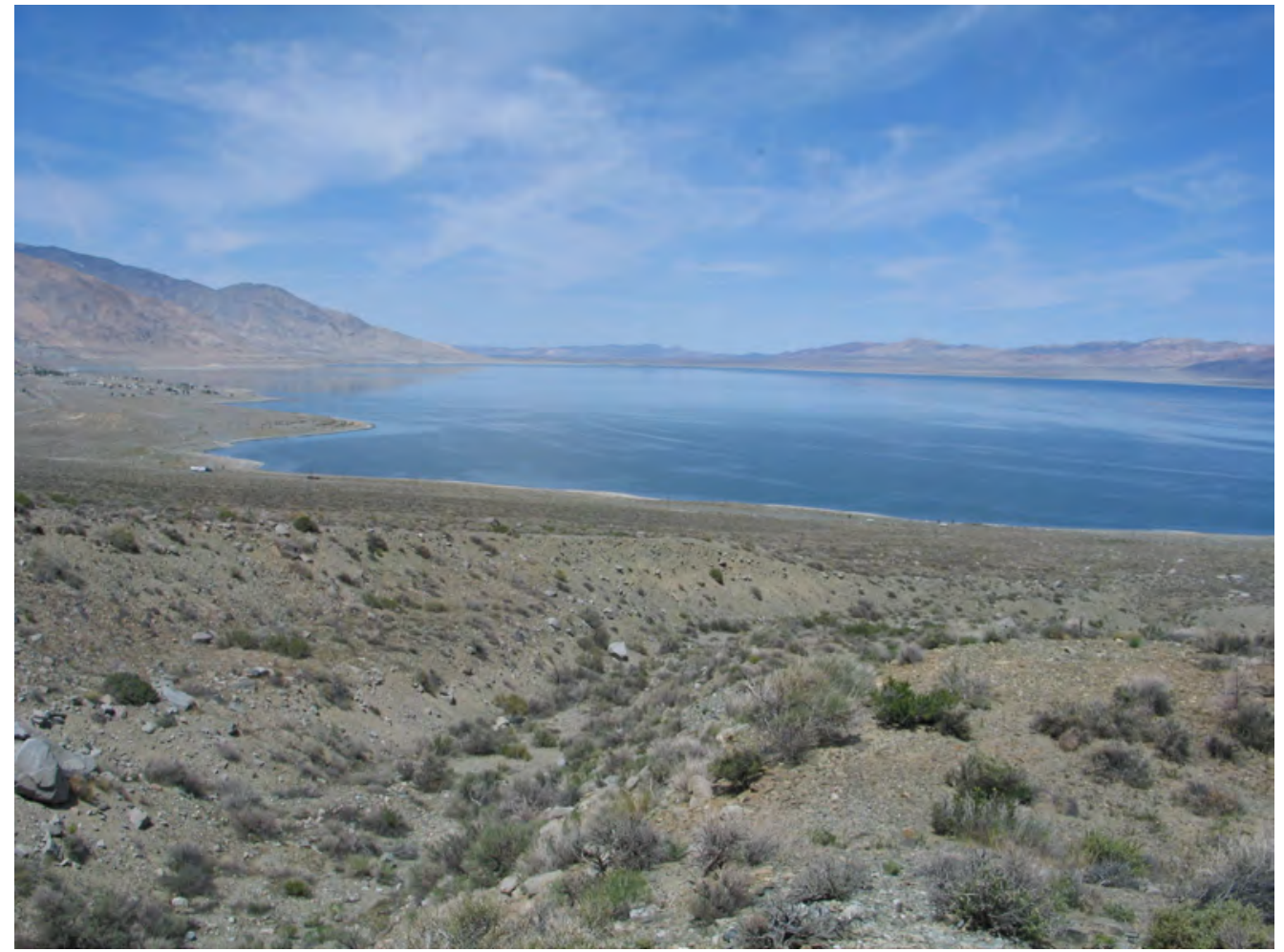

Figure 2. View looking north from the southern end of Walker Lake, Nevada. (Photograph taken by Thomas J. Lopes, April 23, 2004.)

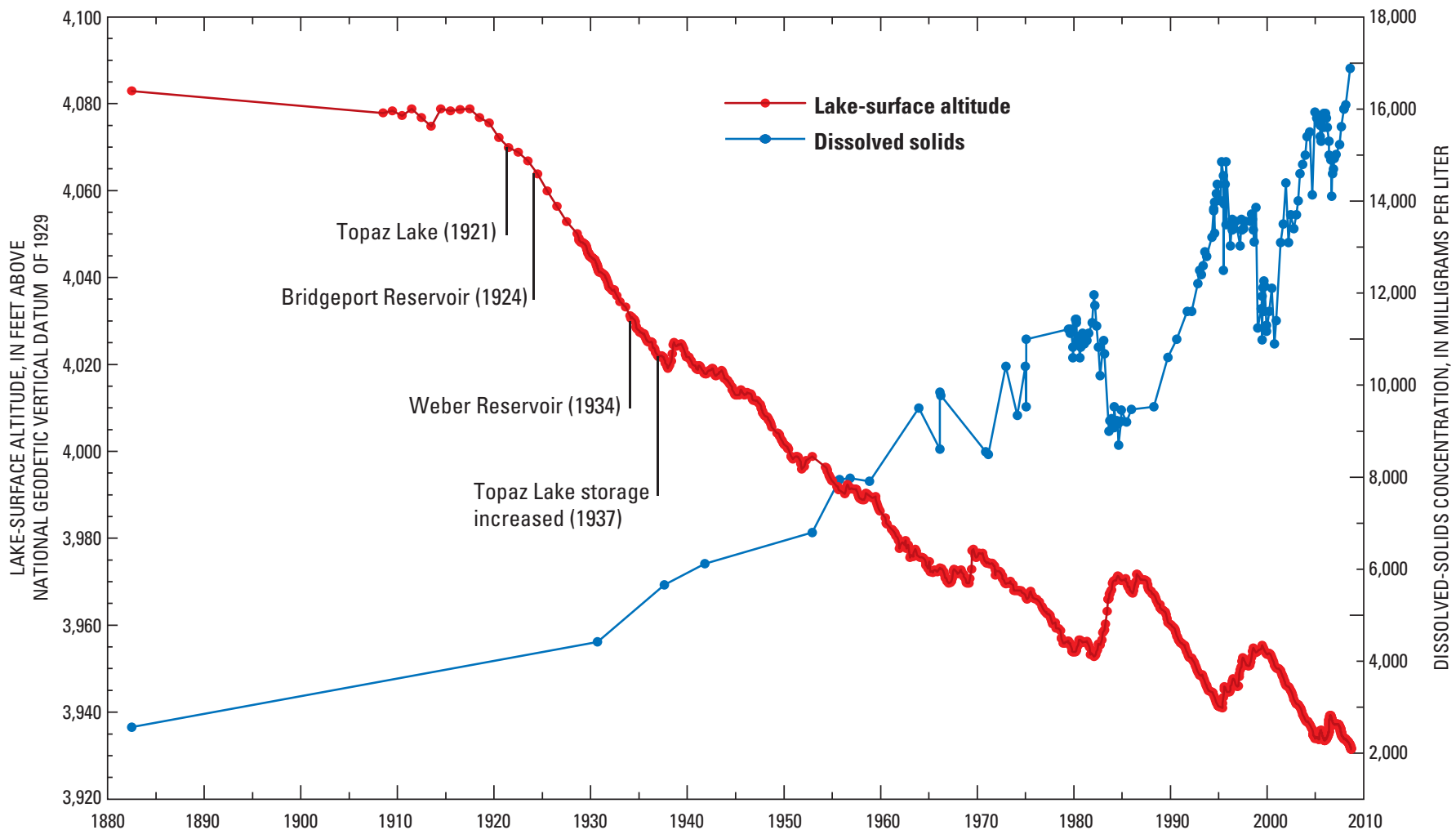

Figure 3. Lake-surface altitude and dissolved-solids concentrations of Walker Lake, Nevada, from 1882 through September 30, 2008. 


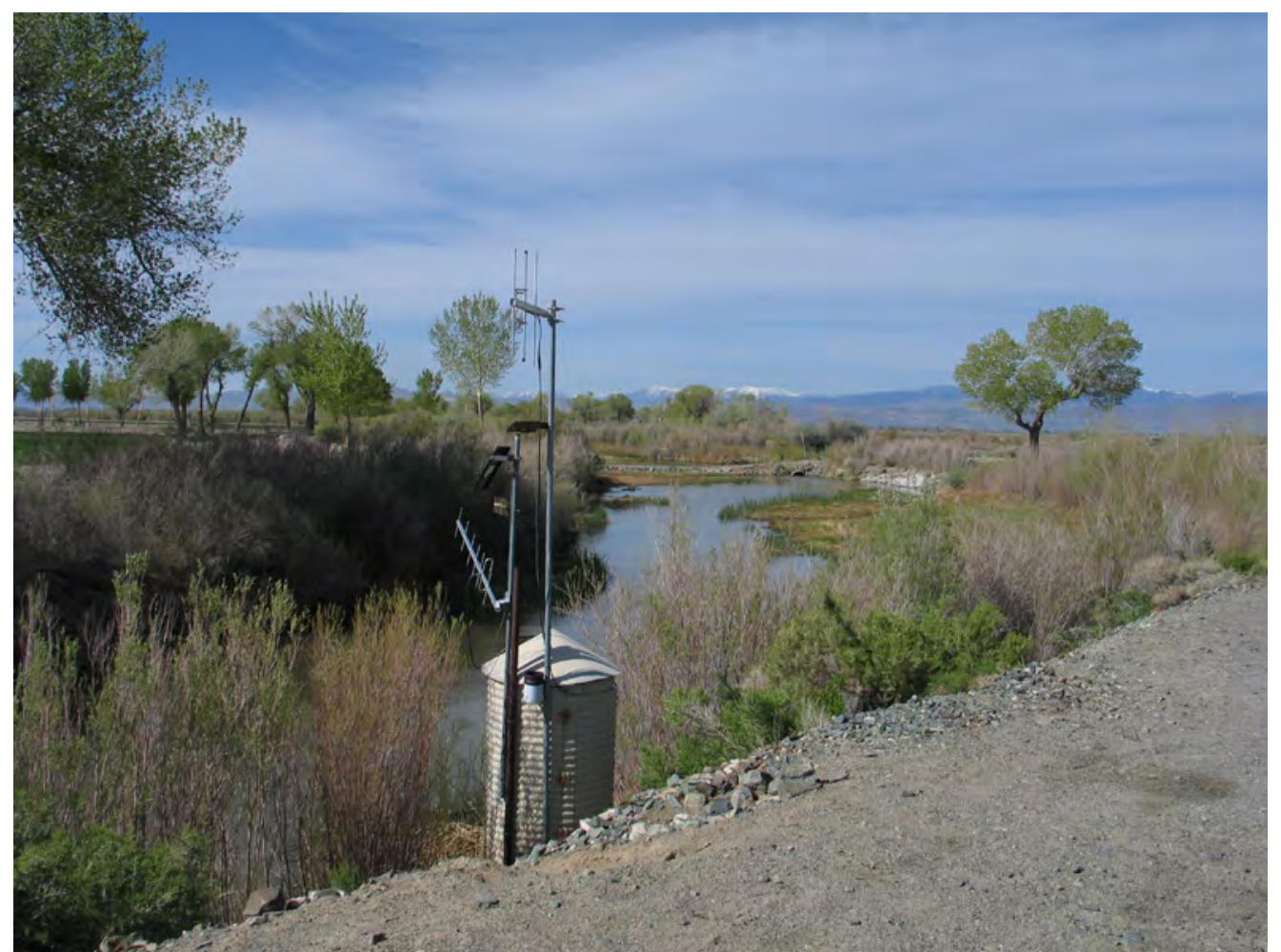

Figure 4. View looking upstream at the streamflowgaging station Walker River near Wabuska, Nevada (10301500). (Photograph taken by Thomas J. Lopes, April 23, 2004.)

\section{Description of the Walker River Basin}

The Walker River basin is about 3,950 $\mathrm{mi}^{2}$ and straddles the California-Nevada border (fig. 1). About 23 percent $\left(920 \mathrm{mi}^{2}\right)$ of the basin is in California. Most streamflow in the basin originates as snowmelt in the Sierra Nevada, which reach an altitude of more than 12,000 ft (fig. 5). Snowmelt from the Sierra Nevada and other ranges flows down the East and West Forks of the Walker River, which merge in southern Mason Valley, Nev. Outflow from Mason Valley and inflow to the lower Walker River basin is measured at the Wabuska streamflow-gaging station in northern Mason Valley.

Bridgeport Reservoir on the East Fork and Topaz Lake on the West Fork of the Walker River are used for fishing, recreation, and have a combined usable storage capacity of about 103,000 acre-ft (figs. 6 and 7). Bridgeport Reservoir is in California and was completed during December 1923 (Horton, 1995). Topaz Lake was built on the CaliforniaNevada border during 1921 by diverting the river into Alkali Lake, a closed basin separated from the Walker River by an alluvial fan. The storage capacity of Topaz Lake was increased in 1937. Stored water is used to irrigate crops in Smith and Mason Valleys and to sustain a minimum streamflow of $26.25 \mathrm{ft}^{3} / \mathrm{s}$ into the Walker River Indian Reservation
(Reservation). Streams also are diverted upstream from Bridgeport Reservoir to irrigate pasture grass (fig. 5) and upstream from Topaz Lake to irrigate mostly alfalfa fields in Antelope Valley (fig. 8).

The Mason Valley Wildlife Management Area (Management Area) is a prominent hydrologic feature in northern Mason Valley that consists of ponds, wetlands, ditches, sloughs, agricultural fields, and a fish hatchery (fig. 9). The Management Area was established in 1955 when 8,766 acres were purchased from a cattle rancher and expanded in 1970 and again in 1993 to a total of 13,735 acres (Horton, 1995). Prior to 1955, ponds and wetlands on the Management Area were created by diverting the Walker River to grow cattle forage (Elmer Bull, Wildlife Staff Specialist, Nevada Department of Wildlife, written commun., 2008). After purchasing the property, the Nevada Department of Wildlife constructed four ponds, which are filled with water from the Walker River, discharge from the fish hatchery and Fort Churchill cooling ponds, and a small amount of effluent from the town of Yerington, Nev. Wells on the Management Area also are used to irrigate wetlands and crops and supply water to the fish hatchery (Nevada Department of Wildlife, 2008). Several sloughs drain excess water into the Walker River about 1 mi north of the Management Area. 


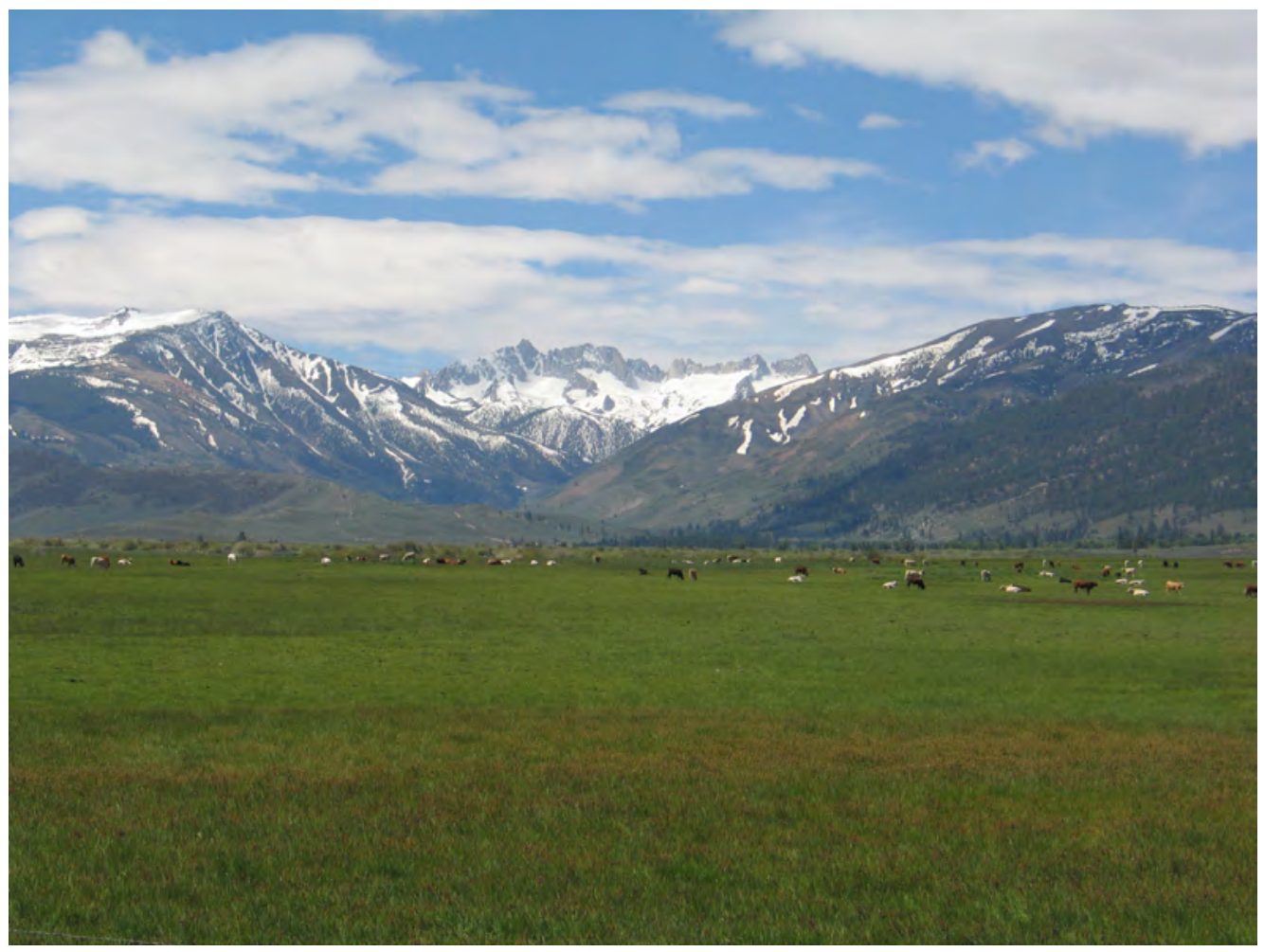

Figure 5. Bridgeport valley, California, looking south from Highway 395 towards Twin Lakes and 12,000 -foot peaks of the Sierra Nevada. Pasture grass in the foreground is irrigated by ditches that divert snowmelt. (Photograph taken by Thomas J. Lopes, June 3, 2008.)

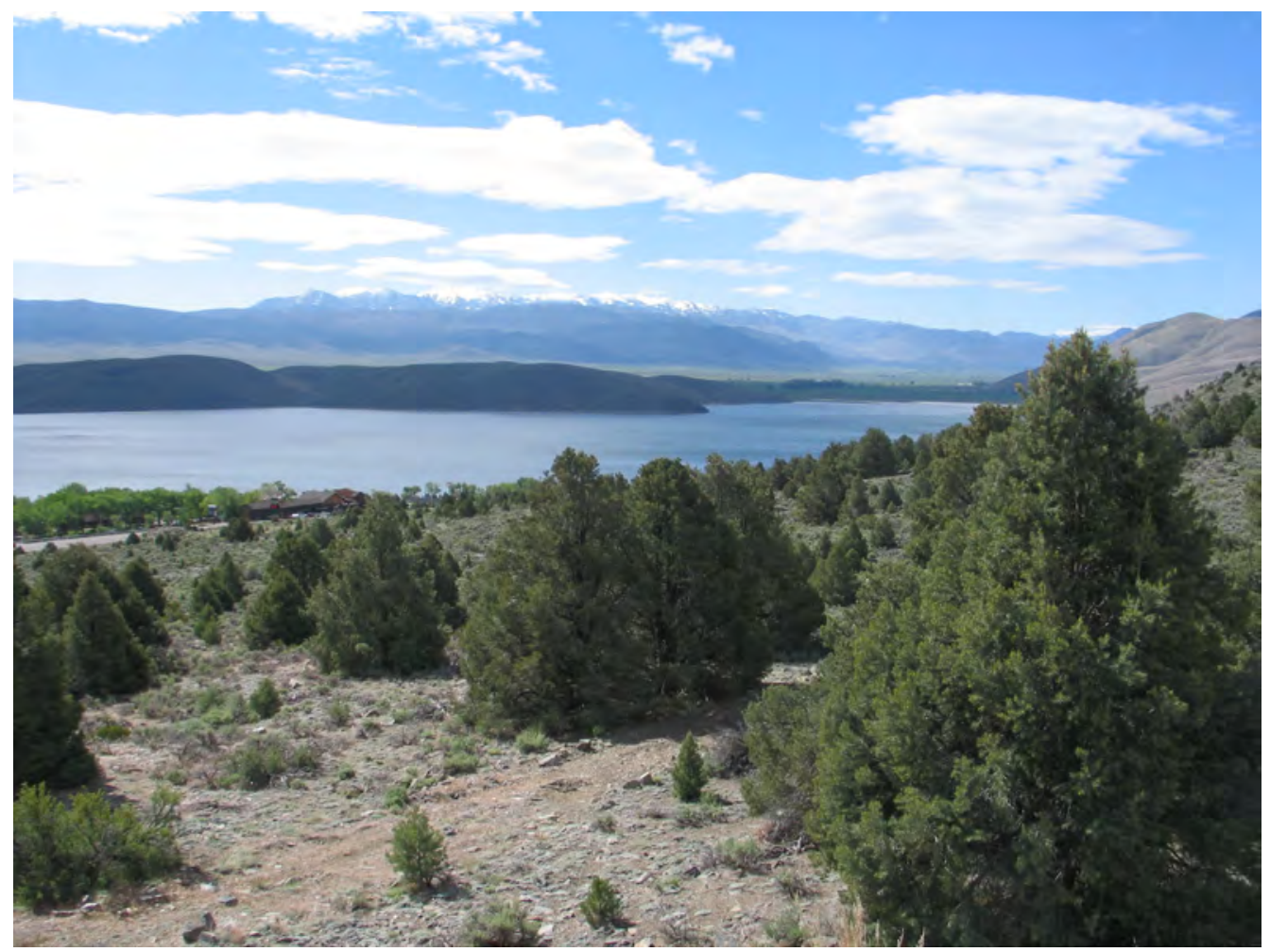

Figure 6. View looking south at Topaz Lake on the West Fork of the Walker River, the upper Antelope Valley, and the snowcapped Sweetwater Range, Nevada and California. (Photograph taken by Thomas J. Lopes, June 3, 2008.) 


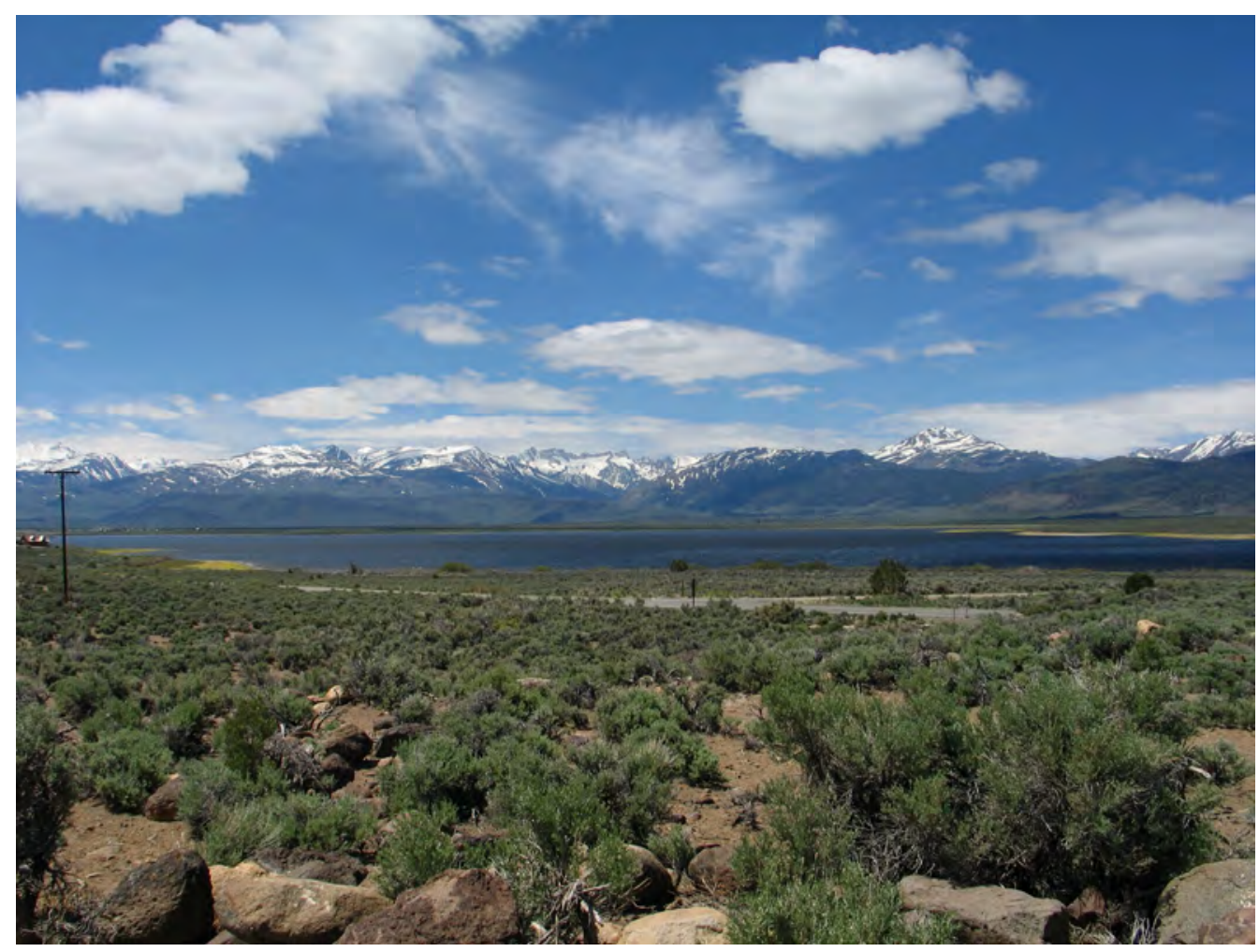

Figure 7. View looking southwest at Bridgeport Reservoir, California, on the East Fork of the Walker River, and the Sierra Nevada. (Photograph taken by Thomas J. Lopes, June 3, 2008.)

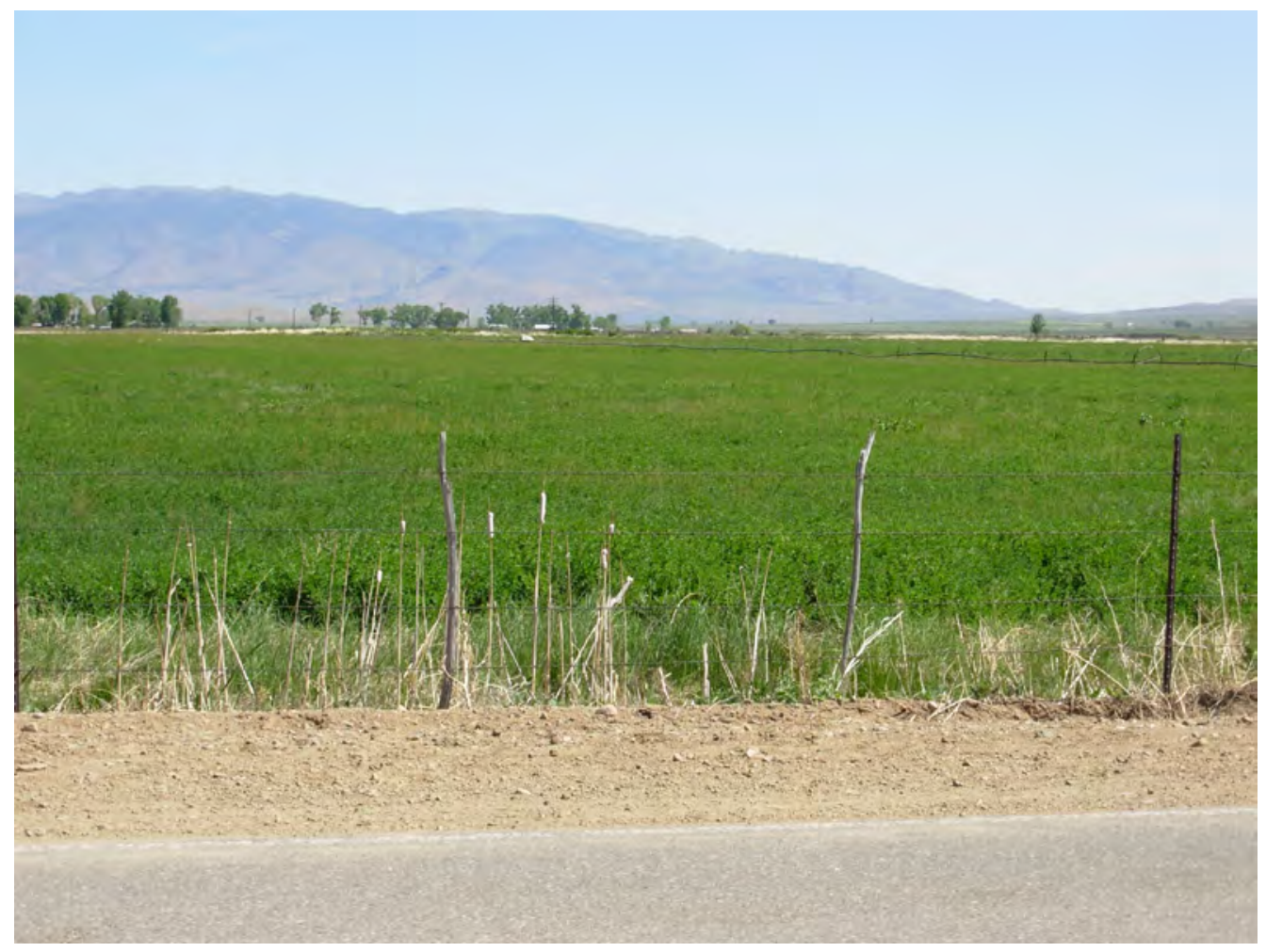

Figure 8. Alfalfa field in Antelope Valley, Nevada and California, with the Sweetwater Range in the background. (Photograph taken by Thomas J. Lopes, May 31, 2006.) 


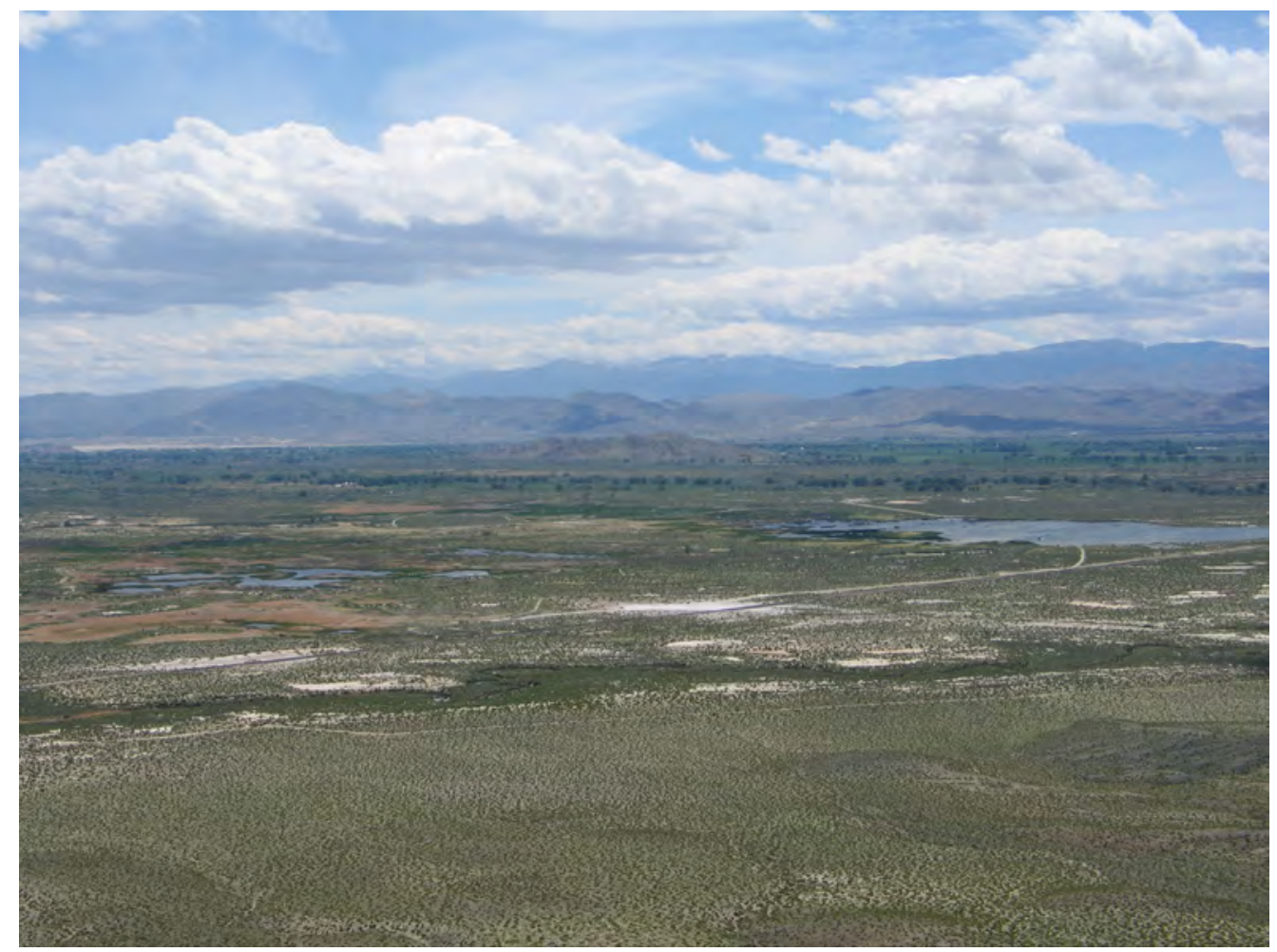

Figure 9. View looking southwest from Parker Butte at the Mason Valley Wildlife Management Area, Nevada. Trees forming a line across the center of the photograph are along the Walker River. The Singatse and Sweetwater Ranges are in the distance. (Photograph taken by Thomas J. Lopes, June 3 , 2008.)

Russell (1885) described lush cottonwood groves, willow stands, and meadows along the banks of the Walker River from its mouth at Walker Lake to many miles upstream. Currently (2008), cottonwood grows along the Walker River in Mason Valley to about 1 mi downstream from the Wabuska gage and along a 14-mi reach below Weber Reservoir (fig. 10). Most cottonwood along the 16-mi reach between the Wabuska gage and Weber Reservoir were cut down.

Except for the cutting of cottonwood, the Walker River between the Wabuska gage and Weber Reservoir is relatively unaffected by human activities (fig. 11). Willow grows along the river, and grass-covered meadows are on the inside banks of stream meanders. Beaver build dams from willow branches along the lower part of this reach. About 2 mi upstream from Weber Reservoir, the Walker River spreads out in braided channels with ponded water and bulrush.

Weber Reservoir was completed in 1934 and is used for fishing, recreation, and storing irrigation water on the Reservation. The original storage capacity was 13,100 acre-ft, but by 1972 sedimentation had reduced the capacity to 10,700 acre-ft (Katzer and Harmsen, 1973). From 2000 to 2007 , storage usually was less than 6,000 acre-ft due to concerns about dam safety (Vicki Moyle, Walker River Paiute Tribe, Safety of Dams Project, oral commun., 2007). The dam was repaired in 2007, which did not change the storage capacity (fig. 12). Fish ladders are planned in anticipation of reintroducing the Lahontan cutthroat trout into the river.

Downstream from Weber Reservoir, cottonwoods grow along the Walker River to about 2 mi downstream from Schurz, Nev., near the 1882 shoreline where cottonwoods were first observed by Russell (1885). The Walker River continues downstream for about $7 \mathrm{mi}$ through 1,089 acres of saltcedar, an invasive shrub (Allander and others, 2009). Saltcedar grows in alkaline lake clays that became exposed as Walker Lake receded. The river then discharges into the northern end of Walker Lake (igg. 13). 


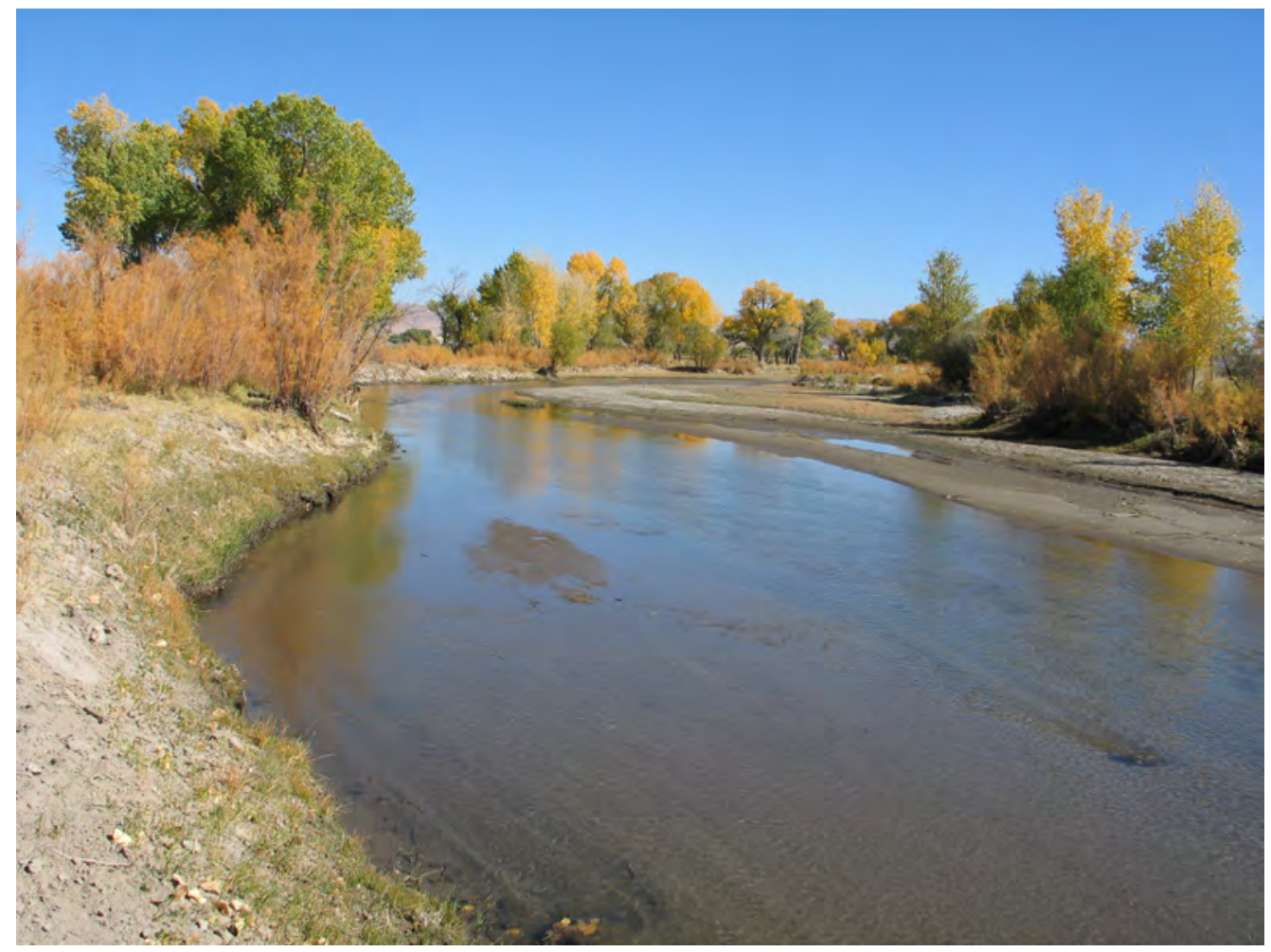

Figure 10. Cottonwood trees along the Walker River just downstream from the Mason Valley Wildlife Management Area, Nevada. (Photograph by taken Thomas Lopes, October 19, 2005.)

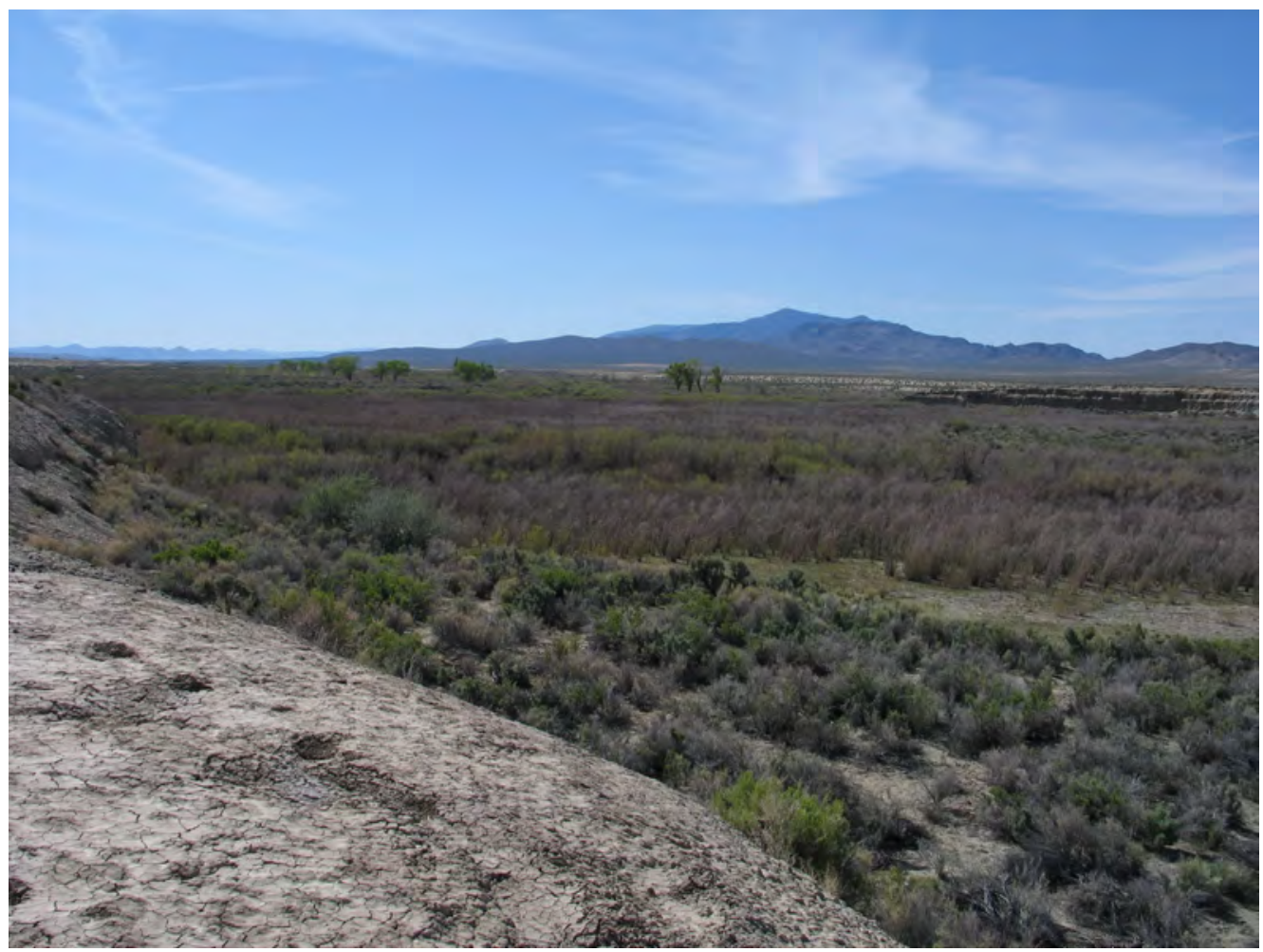

Figure 11. Riparian vegetation along the Walker River between the Wabuska gaging station and Weber Reservoir, Nevada. Bare soil in the foreground is lake sediment deposited during the Pleistocene. View looking south towards the Wassuk Range. (Photograph taken by Thomas J. Lopes, April 23, 2004.) 


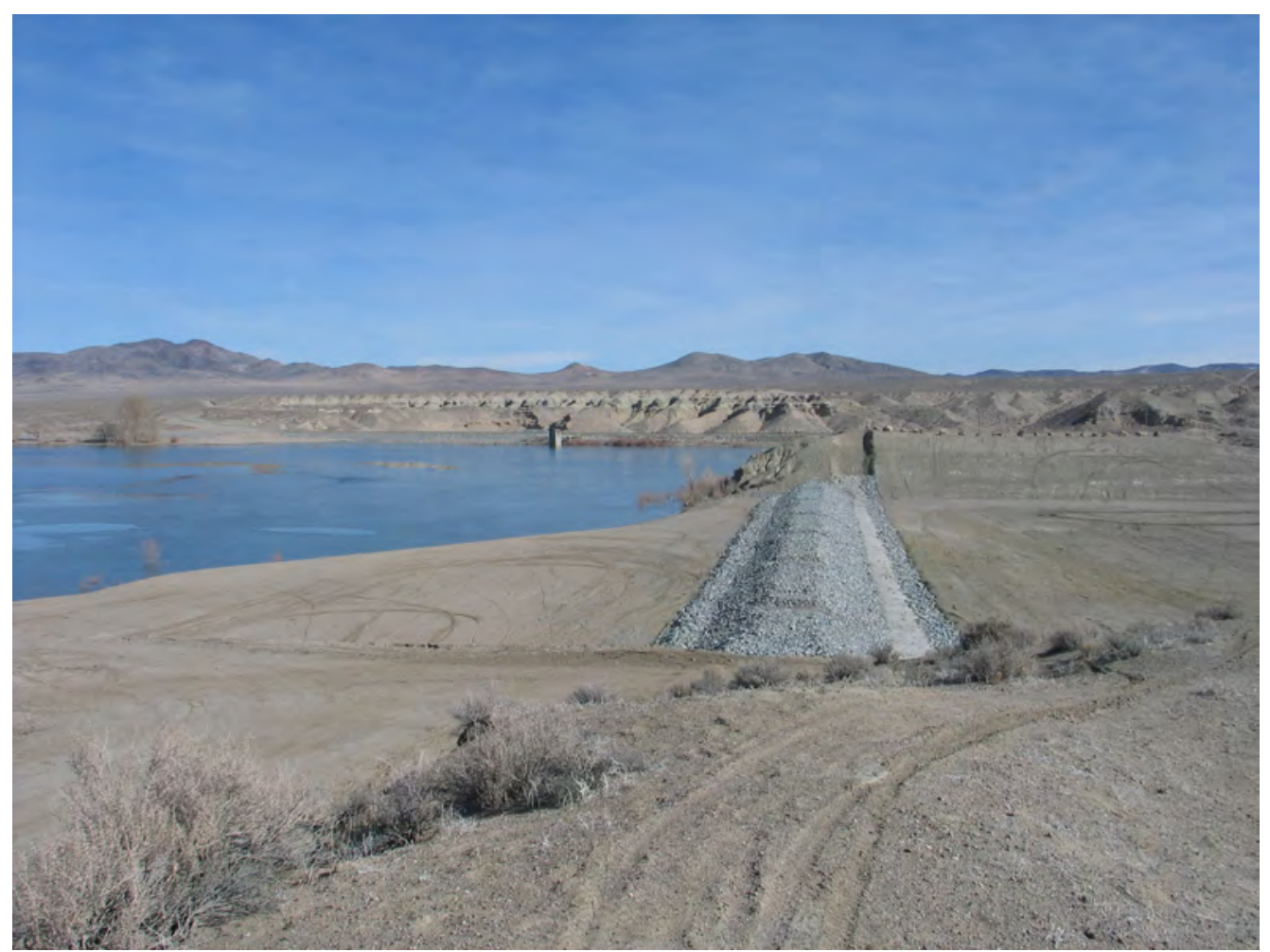

Figure 12. Spillway at the repaired Weber Dam, Nevada. (Photograph taken by Thomas J. Lopes, February 6, 2008.)

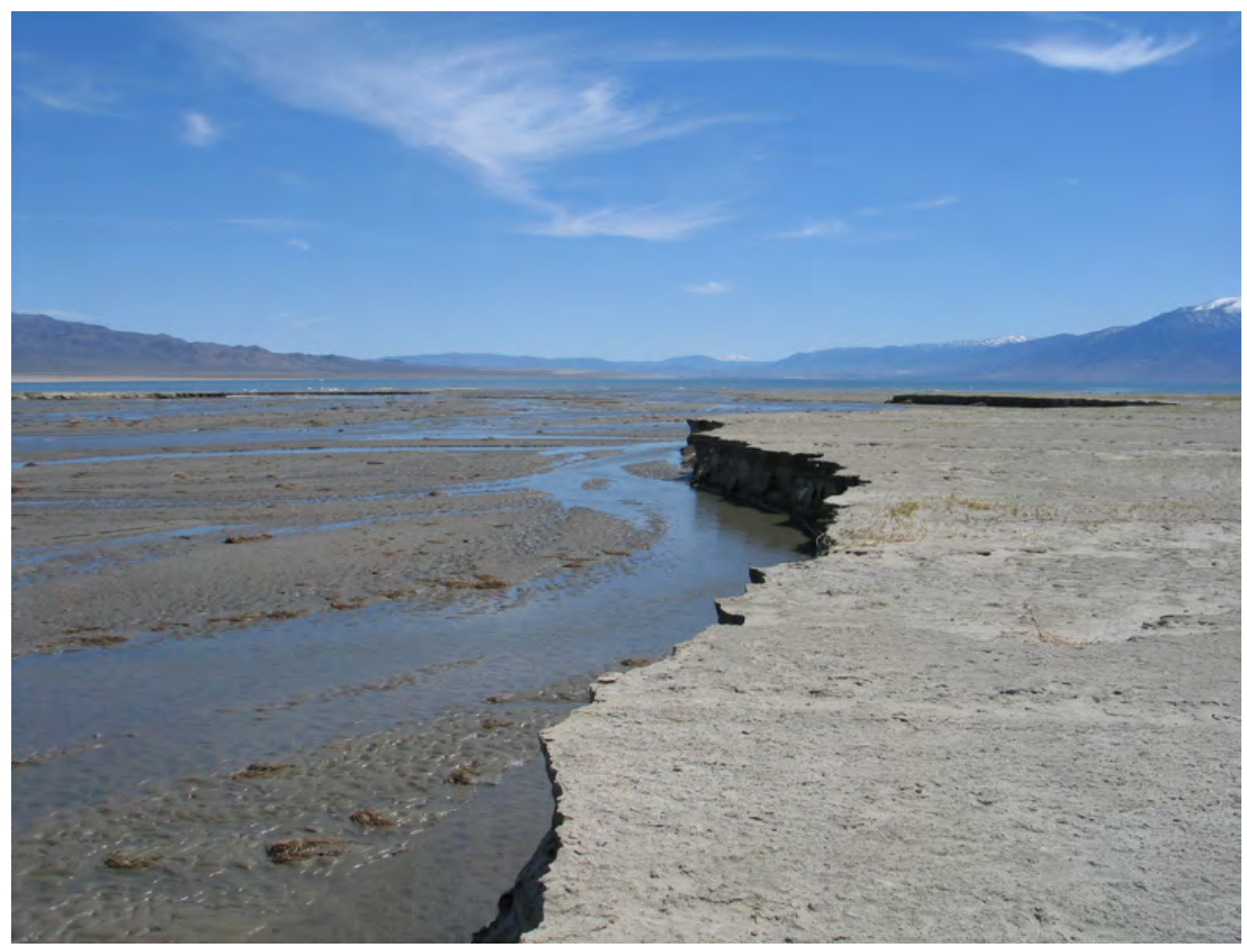

Figure 13. View looking south at Walker Lake from the mouth of the Walker River, Nevada. (Photograph taken by Thomas J. Lopes, April 23, 2004.) 


\section{Physiography}

The Walker River basin is in the Great Basin subdivision of the Basin and Range Physiographic Province. The Basin and Range covers much of the southwestern United States and northwestern Mexico and is characterized by north-south trending mountain ranges that are separated by valleys. The Great Basin is the part of the Basin and Range that has no surface-water drainage to the ocean, is centered in Nevada, and includes parts of California, Idaho, Oregon, and Utah.

Many watersheds in the Great Basin are comprised of multiple valleys that are interconnected by streams and subsurface flow (Anning and Konieczki, 2005). Runoff flows through the valleys, and the valley at the lowest elevation is the terminus for runoff in the watershed. Most watersheds in the Great Basin do not have perennial rivers, so the terminus is a playa consisting of barren mud and salt flats with intermittent water. Artesia Lake in northern Smith Valley is a typical playa in the Great Basin (fig. 14). The Bonneville Salt Flats, Utah, and Death Valley, Calif., are well known large playas. Terminuses that have perennial water include Mono
Lake, Calif., and the Great Salt Lake, Utah. Owens Lake, Calif., was a perennial terminal lake until the early 1900s when diversions turned the lake into a $100 \mathrm{mi}^{2}$ playa. Walker, Pyramid, and Summit Lakes are three of the few terminal lakes in the United States that support a fishery.

Walker Lake is bounded on the west by the Wassuk Range and on the east by the Gillis Range. The Wassuk Range rises abruptly from the lake by more than 7,000 ft and has a maximum altitude of 11,239 ft at Mount Grant (fig. 15). The Gillis Range is not as steep and has a maximum altitude of 7,887 ft (fig. 16). The lowest altitude is 3,849 ft at the deepest part of Walker Lake (Lopes and Smith, 2007).

Walker Lake is a depression within the Walker Lane, a broad zone of mostly north-northwest trending faults that extends from near Las Vegas, Nev., to Honey Lake Valley, Calif. (Bonham, 1969; Stewart, 1988). The Walker Lane is a complex fault system with both extensional and rightlateral, strike-slip faulting with as much as $40 \mathrm{mi}$ of lateral displacement in the Walker Lake area (Wesnonsky, 2005). Several faults have been mapped adjacent to and north of Walker Lake.

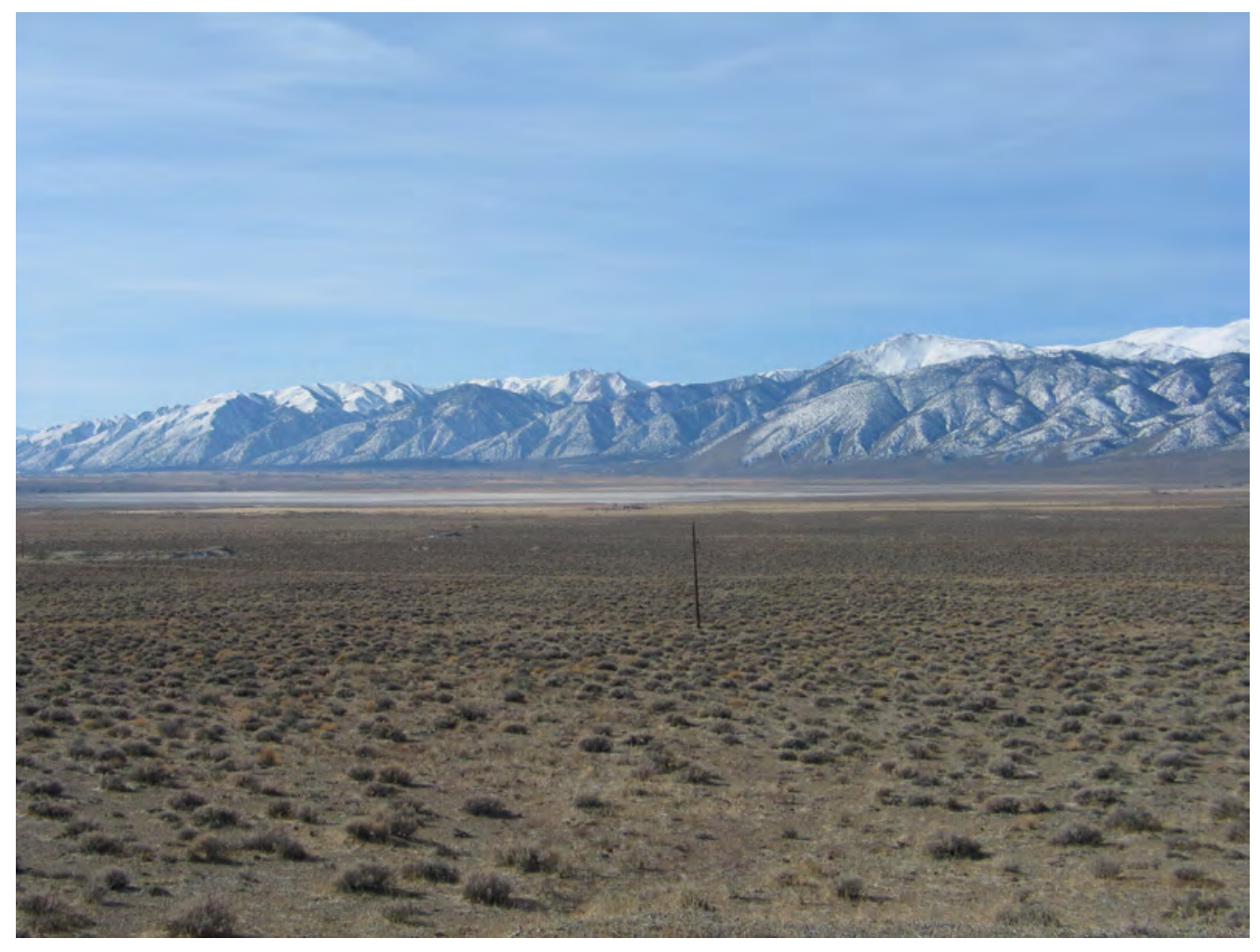

Figure 14. View from northeastern Smith Valley looking southwest towards Artesia Lake and the Pine Nut Range, Nevada. (Photograph taken by Thomas J. Lopes, February 6, 2008.) 


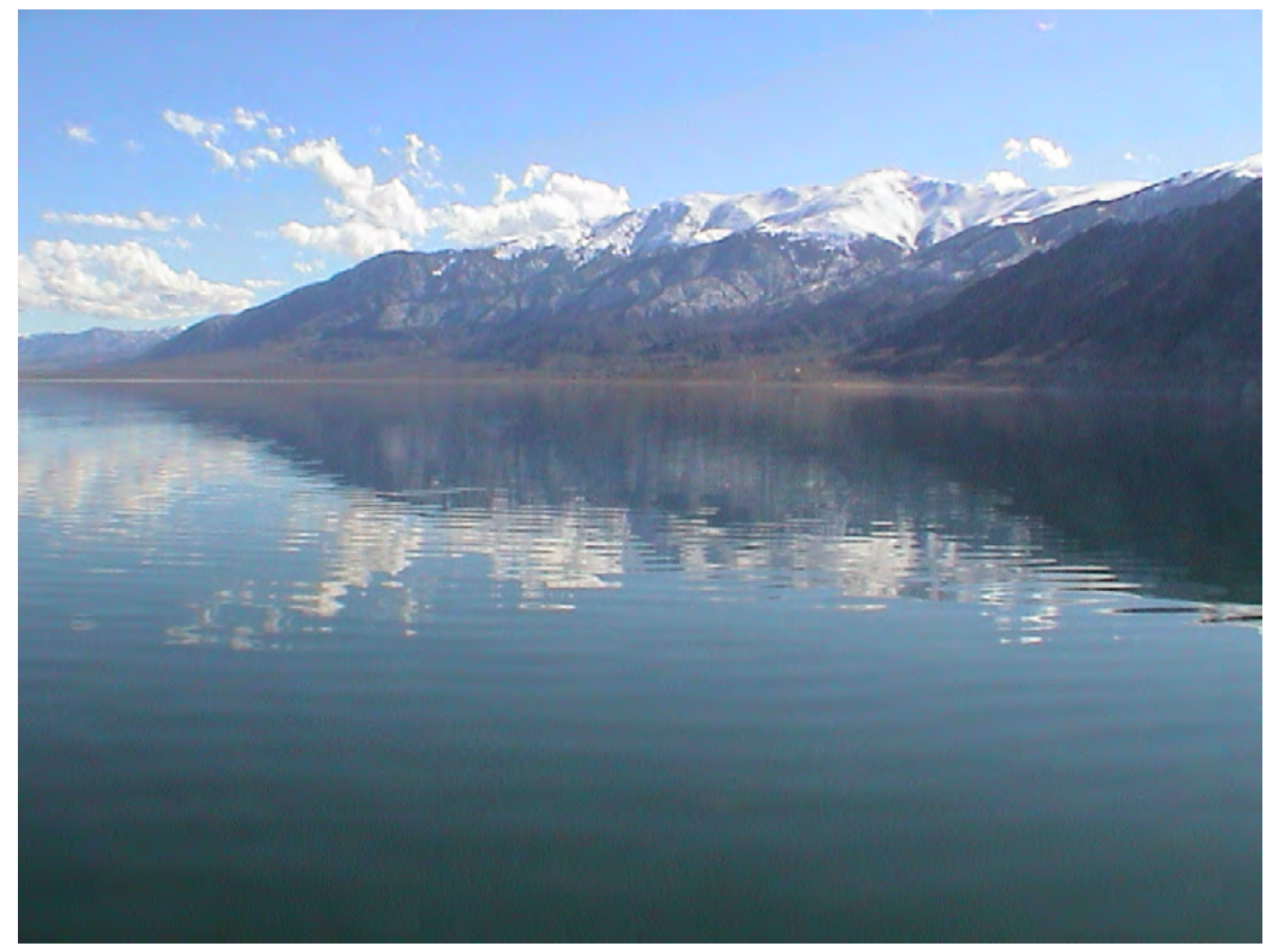

Figure 15. View from Walker Lake looking southwest at Mount Grant, Nevada. (Photograph taken by Thomas J. Lopes, February 28, 2005.)

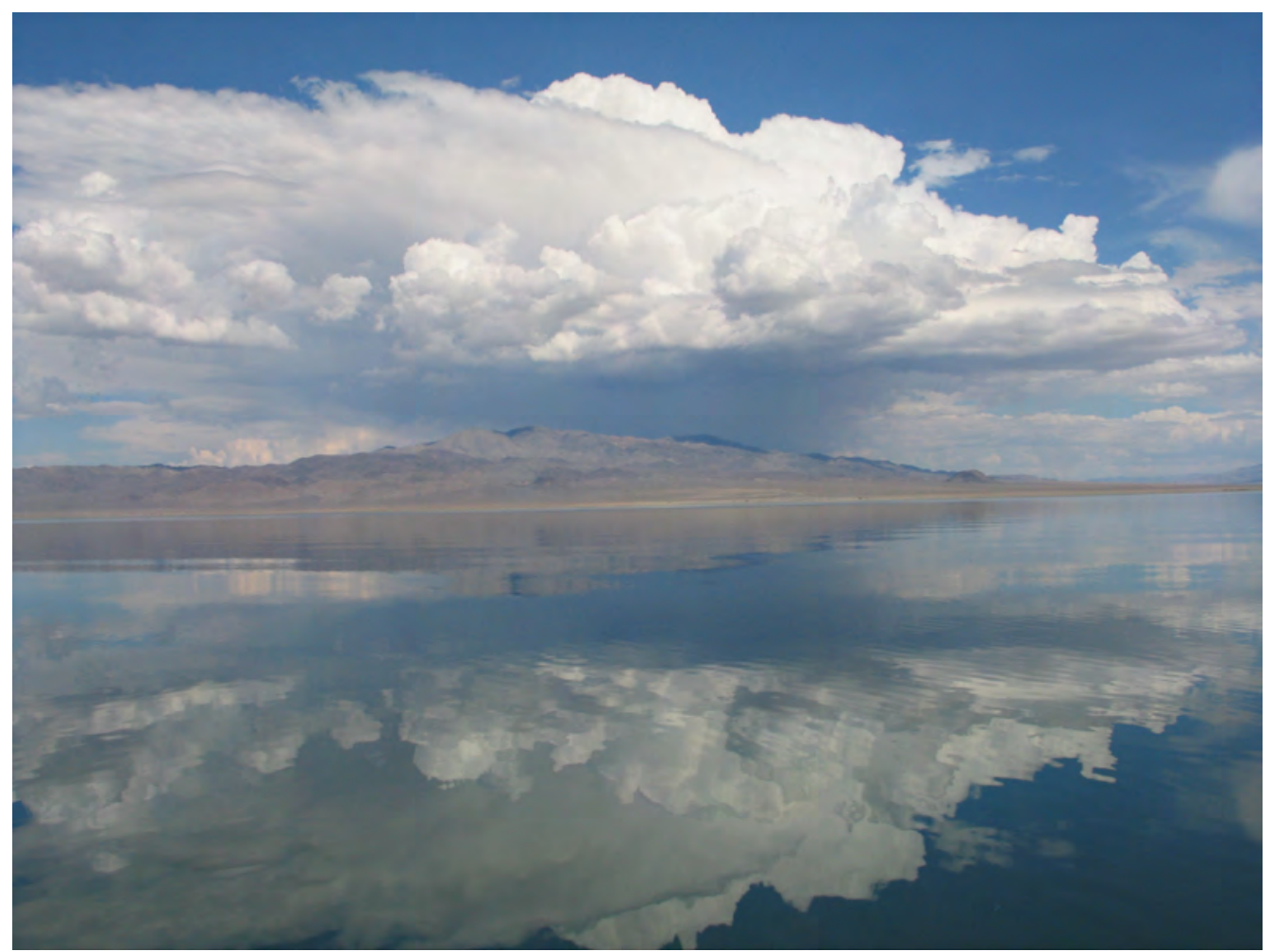

Figure 16. View from Walker Lake looking east at a thunderstorm over the Gillis Range, Nevada. (Photograph taken by Thomas J. Lopes, July 25, 2007.) 


\section{Climate}

Precipitation in Nevada is highly variable temporally and spatially. Cold fronts and monsoons are the two seasonal weather patterns that bring precipitation to Nevada (Houghton and others, 1975). From about September through May, prevailing westerly winds push cold fronts that originate in the Gulf of Alaska and northern Pacific Ocean across Nevada. Cold fronts typically are long-duration, low-intensity, broad storms that account for about 75 percent of the annual precipitation in the Walker River basin. During some winters, relatively warm storms originate from the central and tropical Pacific Ocean (Friedman and others, 2002). These storms can have large amounts of moisture and cause flooding, especially when rain falls on snow such as during the 1997 flood (Thomas and Hess, 1997). The highest peak flows at six stream gages in the Walker River basin were measured during this flood, which raised Walker Lake about $4 \mathrm{ft}$. From about June through August, southwesterly winds bring monsoonal moisture from the Gulfs of Mexico and California. Monsoons typically are short-duration, high-intensity, localized thunderstorms that account for about 25 percent of the annual precipitation in the Walker River basin. Months with no precipitation are common between cold fronts and monsoons.

The spatial distribution of precipitation in Nevada is influenced strongly by latitude and land-surface altitude (Houghton and others, 1975). Precipitation throughout Nevada generally increases with latitude and altitude. The most important variable influencing the distribution of precipitation is continentality (Houghton and others, 1975), which is more commonly called the rain-shadow effect. The rain-shadow effect is the relatively dry climate on the leeward side of a mountain range compared to the windward side. As air rises over the windward side, air cools and moisture condenses as rain and snow. Air descending the leeward side of the mountain warms and condensation evaporates, resulting in the dry climate downwind from the mountains.

Type of precipitation is important because snowmelt is the primary source of streamflow and groundwater recharge in the Walker River basin. Topographic slope and aspect are important variables in snow accumulation, sublimation, and soil infiltration. The 25-percent slope break is a critical condition for snow stability (Gray and Male, 1981). Slopes greater than 25 percent are less likely to have much snow accumulation due to avalanches. Aspect is the average compass direction that a slope faces and affects the rate of snowmelt and sublimation. Easterly, westerly, and flat aspects receive similar amounts of solar radiation. Southerly aspects receive the most solar radiation, and northerly aspects receive considerably less radiation than non-northerly aspects (Gray and Male, 1981). As a result, snowmelt is more likely to recharge on flat, northerly slopes, and sublimate and runoff from steep, non-northerly slopes.

Climatic data have been collected at 19 weather stations in the Walker River basin (table 1). The National Weather Service considers 30 consecutive years to be a sufficiently long period for a calculated mean to represent the true mean of a climatic parameter. Normals are the mean annual value for a 30-year period, are calculated at 10-year intervals, and have been calculated for 1961-90 and 1971-2000. Lopes and Medina (2007) used data from these and other stations to develop four regression equations and to estimate the distribution of 1971-2000 precipitation normals in the Walker River basin and surrounding areas of west-central Nevada (figs. 1 and 17). Estimated precipitation normals range from 4 in. at Walker Lake to 56 in. along the crest of the Sierra Nevada (Lopes and Medina, 2007). Mount Grant, the highest mountain adjacent to Walker Lake, has a 1971-2000 normal of about $16 \mathrm{in} / \mathrm{yr}$. However, precipitation normals are the average of dry and wet periods and seldom occur during any particular year.

The State of Nevada divided major hydrographic basins into 232 hydrographic areas for planning and management purposes (Cardinalli and others, 1968; Rush, 1968). The Walker River basin is comprised of hydrographic areas 106 (Antelope Valley), 107 (Smith Valley), 108 (Mason Valley), 109 (East Walker Area) and 110 (Walker Lake Valley). Hydrographic area 110 is divided into the Schurz Subarea (110A), Lake Subarea (110B), and Whisky Flat-Hawthorne Subarea (110C). Lopes and Medina (2007) used topographic divides to extend the boundaries of hydrographic areas 106 and 109 to the crest of the Sierra Nevada in California and calculated the total volume of precipitation for the five hydrographic areas (table 2). Hydrographic areas 106 and 109 receive the largest amount of precipitation in the Walker River basin, especially areas receiving greater than $24 \mathrm{in} / \mathrm{yr}$ of precipitation. Lopes and Medina (2007) estimated 18 percent less precipitation in the Walker River basin compared to the Parameter-elevation Regressions on Independent Slopes Model (PRISM; Daly and others, 1994), which is another source of precipitation estimates for the Walker River basin.

Like precipitation, the spatial distribution of air temperature normals is influenced strongly by latitude and land-surface elevation (Lopes, 2006). Minimum and maximum temperature normals in the Walker River basin range from between 25 and $95^{\circ} \mathrm{F}$, respectively, at Hawthorne Airport, Nev., to between 6 and $77^{\circ} \mathrm{F}$, respectively, at Bodie, Calif. (table 1). Extreme temperature ranges from about- 30 to $110^{\circ} \mathrm{F}$. Typically, July is the hottest month and December is the coldest month. 
From November 2004 through November 2006, average wind speed ranged from 3 to $5 \mathrm{mi} / \mathrm{h}$ on the valley floor of the lower Walker River basin and $9 \mathrm{mi} / \mathrm{h}$ on Walker Lake. The predominant wind direction was from the southwest. The closest weather station with long-term wind data is Fallon,
Nev., about 50 mi north of Walker Lake. The 1996-2006 mean annual wind speed at Fallon is $7 \mathrm{mi} / \mathrm{h}$. Mean monthly wind speed ranges from $5.6 \mathrm{mi} / \mathrm{h}$ in November to $8.6 \mathrm{mi} / \mathrm{h}$ in April. Winds are mainly from the south during late autumn and winter and from the north or west during the rest of the year.

Table 1. Precipitation and temperature normals at weather stations in the Walker River basin, Nevada and California, 1971-2000.

[Stations arranged in order of increasing elevation. Network: COOP, National Weather Service Cooperative Observer Program; SNOTEL, National Resource Conservation Service SNOw TELemetry. Precipitation: estimated normals from Lopes and Medina (2007). Abbreviations MSL, mean sea level; in/yr, inch per year; Calif., California; Nev., Nevada; ${ }^{\circ}$ F, degrees Fahrenheit; Dec., December; Jan., January; -, not available]

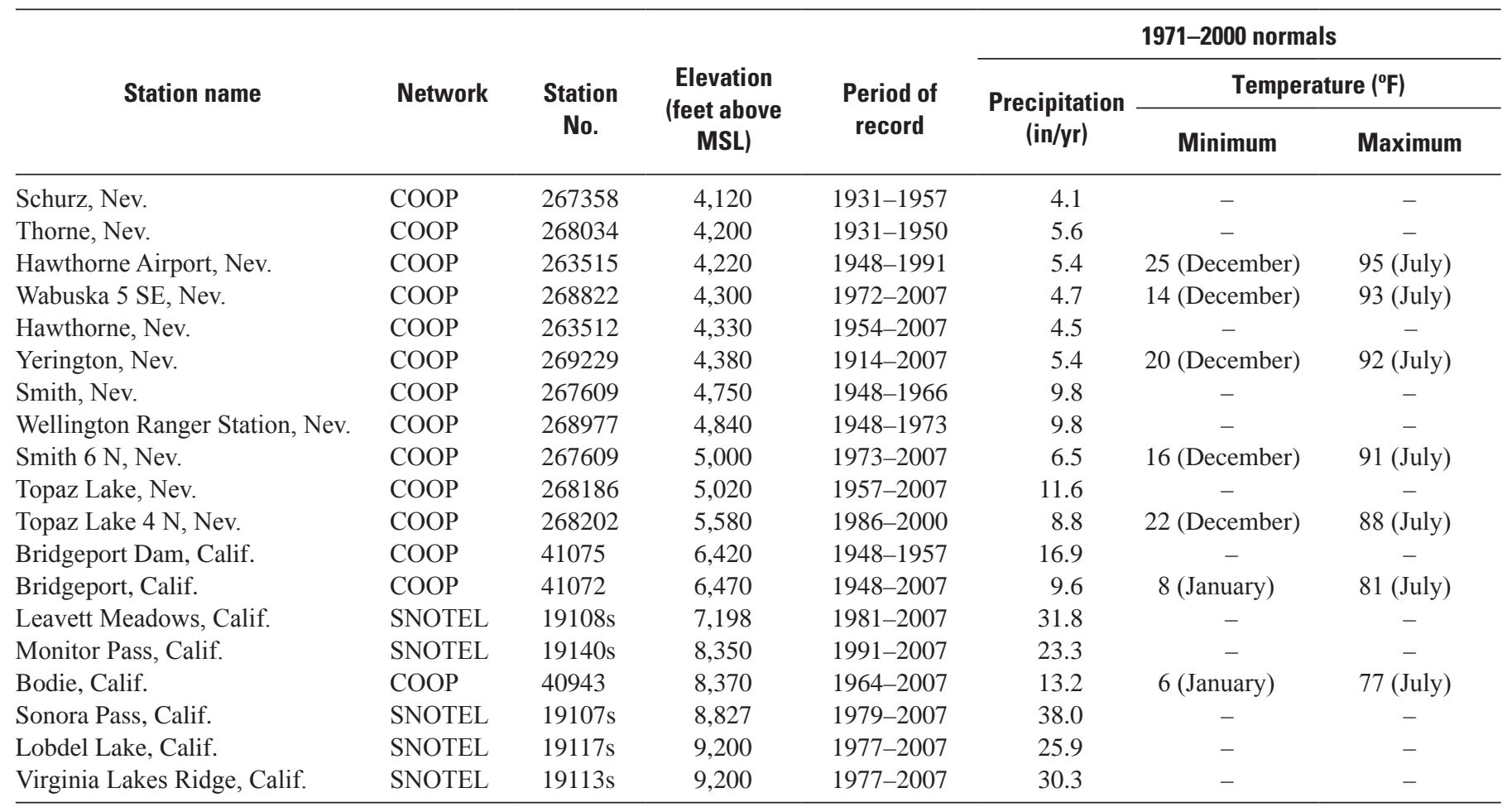

Table 2. Precipitation volumes for hydrographic areas in the Walker River basin, Nevada and California.

[Precipitation estimated normals from Lopes and Medina, 2007.

Abbreviations: LCL, lower 95th-percentile confidence limit of mean; UCL, upper 95th-percentile confidence limit of mean]

\begin{tabular}{|c|c|c|c|}
\hline \multirow[t]{2}{*}{ Hydrographic Area } & \multicolumn{3}{|c|}{$\begin{array}{l}\text { Precipitation-zone method } \\
\text { (acre-feet per year) }\end{array}$} \\
\hline & LCL & Mean & UCL \\
\hline 106 Antelope Valley & 552,000 & 591,000 & 630,000 \\
\hline 107 Smith Valley & 295,000 & 319,000 & 342,000 \\
\hline 108 Mason Valley & 152,000 & 164,000 & 176,000 \\
\hline 109 East Walker Area & 737,000 & 786,000 & 835,000 \\
\hline 110 Walker Lake Valley & 452,000 & 487,000 & 520,000 \\
\hline
\end{tabular}




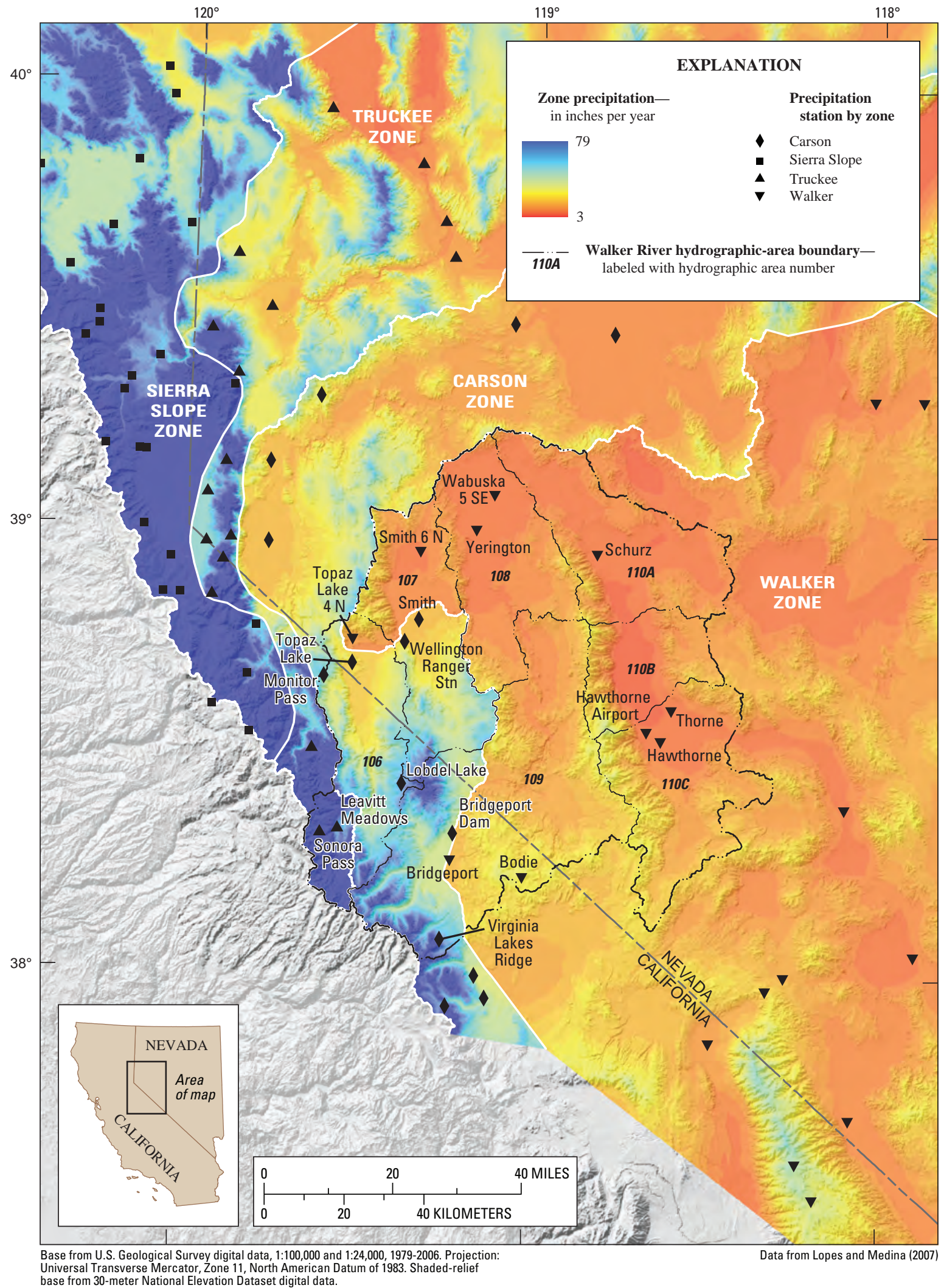

Figure 17. Distribution of precipitation in the Walker River basin, Nevada and California. 


\section{Natural and Agricultural Vegetation}

Natural vegetation in the study area can be grouped into three vegetation communities: (1) a scrub brush community that is prevalent in the valleys except along the river; (2) a pinyon-juniper woodland community that is prevalent in the Wassuk Range at altitudes between 5,500 ft and 9,000 ft; and (3) a riparian community that grows along most of the lower Walker River, just south of Walker Lake in an area of groundwater discharge, and along perennial streams in the Wassuk Range.

The scrub brush community grows where there is little or no water from streams or groundwater. This community relies mostly on direct precipitation but, in some areas, plants transpire shallow groundwater. The scrub brush community is predominately very sparse to sparse greasewood (Sarcobatus vermiculatus), sagebrush (Artemisia tridentata), and rabbitbrush (Chrysothamnus spp.). Plants tend to be denser and lusher near the riparian corridor.

The pinyon-juniper woodland community grows at intermediate altitudes within the study area where precipitation ranges from about 7 to $13 \mathrm{in} / \mathrm{yr}$ based on estimates from Lopes and Medina (2007). This vegetation community is predominately pinyon pine trees (Pinus monophylla) and juniper trees (J uniperus spp.). Sagebrush also grows in open areas and between the trees. The pinyon-juniper woodland community relies on direct precipitation for its water needs.

The riparian community grows where there is abundant water from streams, groundwater, or both. The riparian community can be dense and lush with trees such as Freemont cottonwood (Populus fremontii) and Russian olive (E laeagnus angustifolia). The riparian community also supports a variety of shrubs and grasses including willow (Salix spp.), rabbitbrush, greasewood, and saltgrass (D istichlis spicata). Two to $3 \mathrm{mi}$ south of Schurz at the 1882 shoreline of Walker Lake, riparian vegetation abruptly changes to saltcedar (Tamarix ramosissima). Saltcedar, also known as tamarisk, is listed by the State of Nevada as a noxious, invasive weed ${ }^{1,2}$. The saltcedar leaf beetle (Diorhabda elongata) was introduced into this area in 2003 and reduced saltcedar transpiration by about 50 percent (Allander and others, 2009).

Mason Valley has long been the most agricultural part of the Walker River basin and remains one of the most productive agricultural areas in Nevada. Agriculture began in 1859 when Nathan Mason built a 20,000-acre cattle ranch in the valley (Horton, 1995). Court records indicate irrigation in the basin began in 1860. From 1861 to 1865, an extensive system of irrigation ditches was built in Mason Valley to divert the Walker River. Alfalfa was introduced into the area in 1864 and by the mid-1870s was the primary crop along the eastern Sierra Nevada.

\footnotetext{
${ }^{1}$ http://agri.nv.gov/Brochures/Invasive $\% 20$ Weed $\% 20$ Indentification $\% 20$ for\%20Nevada\%20SP\%2003-09.pdf; accessed February 1, 2008.

${ }^{2}$ http://plants.usda.gov/java/noxious?rptType=State\&statefips $=32$; accessed February 1, 2008.
}

Most of Mason Valley was mapped as agricultural by Russell (1885), who described "irrigable lands where abundant harvests are annually secured." On June 4, 1881, Russell (1885) measured $400 \mathrm{ft}^{3} / \mathrm{s}$ about 3 mi upstream from the mouth of the Walker River near Schurz, Nev. In October 1882, the river at this location was dry and "little, if any, water reached the lake from this source." According to Russell (1885), the lack of streamflow was "due in a great measure to the extensive use of its waters for irrigation in Mason Valley."

Russell (1885) did not map agriculture in Antelope and Smith Valleys, but priorities for appropriated water-rights indicate irrigation in Antelope Valley began around 1862 (Horton, 1995). Diversions in Smith Valley began in 1890 with construction of the Colony Ditch. In 1919, the U.S. Census of Agriculture reported 103,000 acres of irrigated land in Mason and Smith Valleys and along the East Fork of the Walker River downstream from Bridgeport Reservoir (Horton, 1995).

Basin-wide mapping of irrigated land was done for this study using false-color Landsat satellite imagery that shows lush vegetation as bright green. Irrigated lands were identified as bright green orthogonal or circular features on the images. Bright green irregular features were assumed to be natural vegetation such as meadows or riparian zones. Previous experience demonstrated that identifying irrigated areas from a single image may not capture all irrigated areas during a growing season. Fields that had been cut recently are not bright green and fields may be irrigated at different times. Therefore, several images taken during the growing season were used to accurately identify irrigated areas.

Images acquired on April 6, July 11, and September 29,2000 , were used to map 88,600 acres of irrigated land in the Walker River basin (fig. 18). Total irrigated land during 2000 included 39,100 acres (44 percent) in Mason Valley; 18,900 acres (21 percent) in Smith Valley; 15,900 acres (18 percent) upstream from Bridgeport Reservoir; 7,700 acres (9 percent) in Antelope Valley; 3,500 acres (4 percent) along the East Fork of the Walker River below Bridgeport Reservoir; 3,000 acres (3 percent) on the Reservation; and 500 acres (less than 1 percent) in Whisky Flat south of Hawthorne, Nev. Irrigated land in Mason Valley, Smith Valley, and below Bridgeport Reservoir is 40 percent less than in 1919 (Horton, 1995). The primary crop in the basin is alfalfa (fig. 8), except upstream from Bridgeport Reservoir where fields are irrigated for pasture grass (fig. 5). Other crops that are grown include onion (fig. 19), garlic, corn, and winter wheat. 


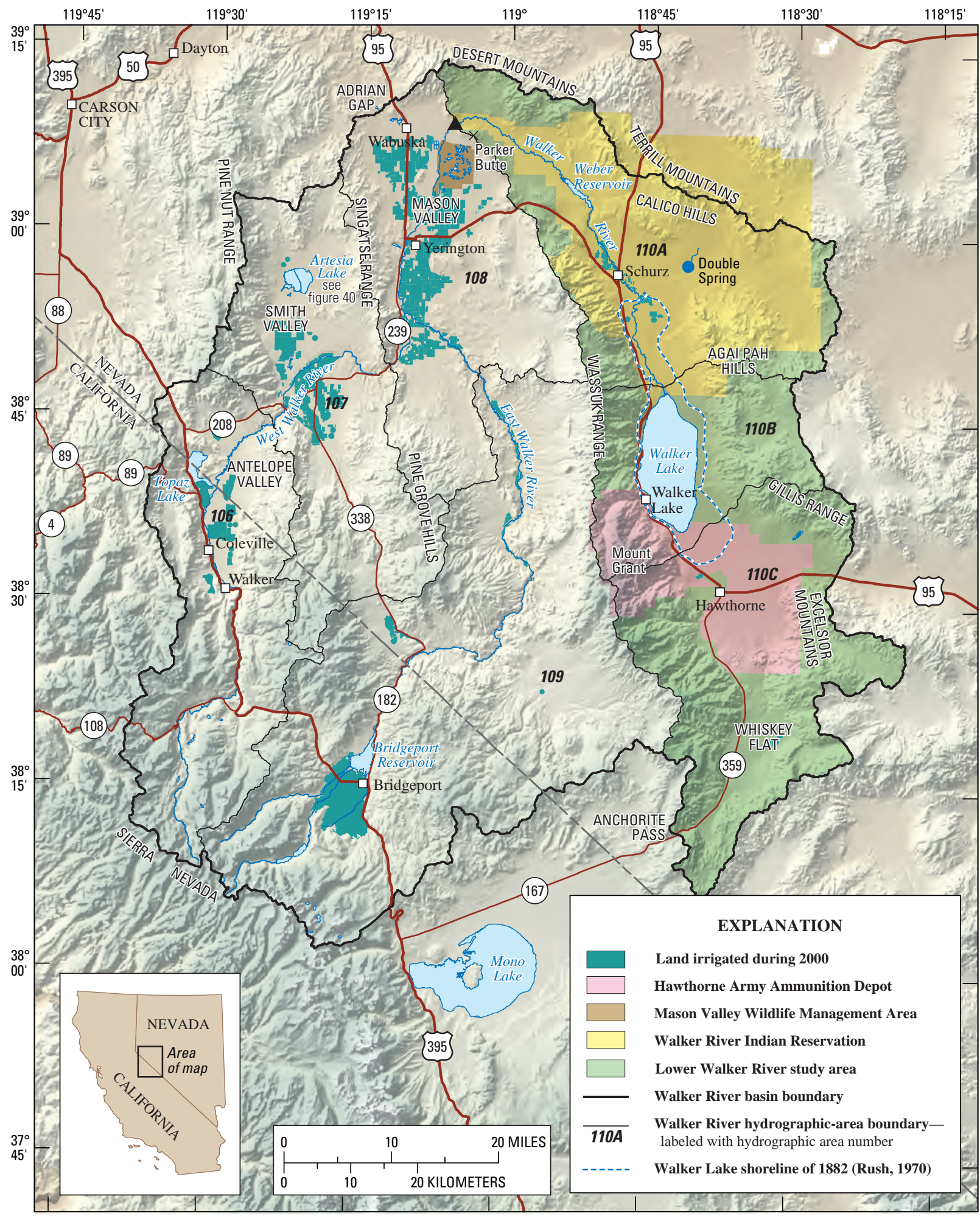

Base from U.S. Geological Survey digital data, 1:24,000 and 1:100,000, 1978-88. Walker Lake

average lake altitude of $3937.5 \mathrm{ft}$ for November 2006; Projection: Universal Transverse

Shuttle Radar Topography Mission digital data, 2000.

Figure 18. The distribution of irrigated land in the Walker River basin, Nevada and California, during the 2000 growing season. 


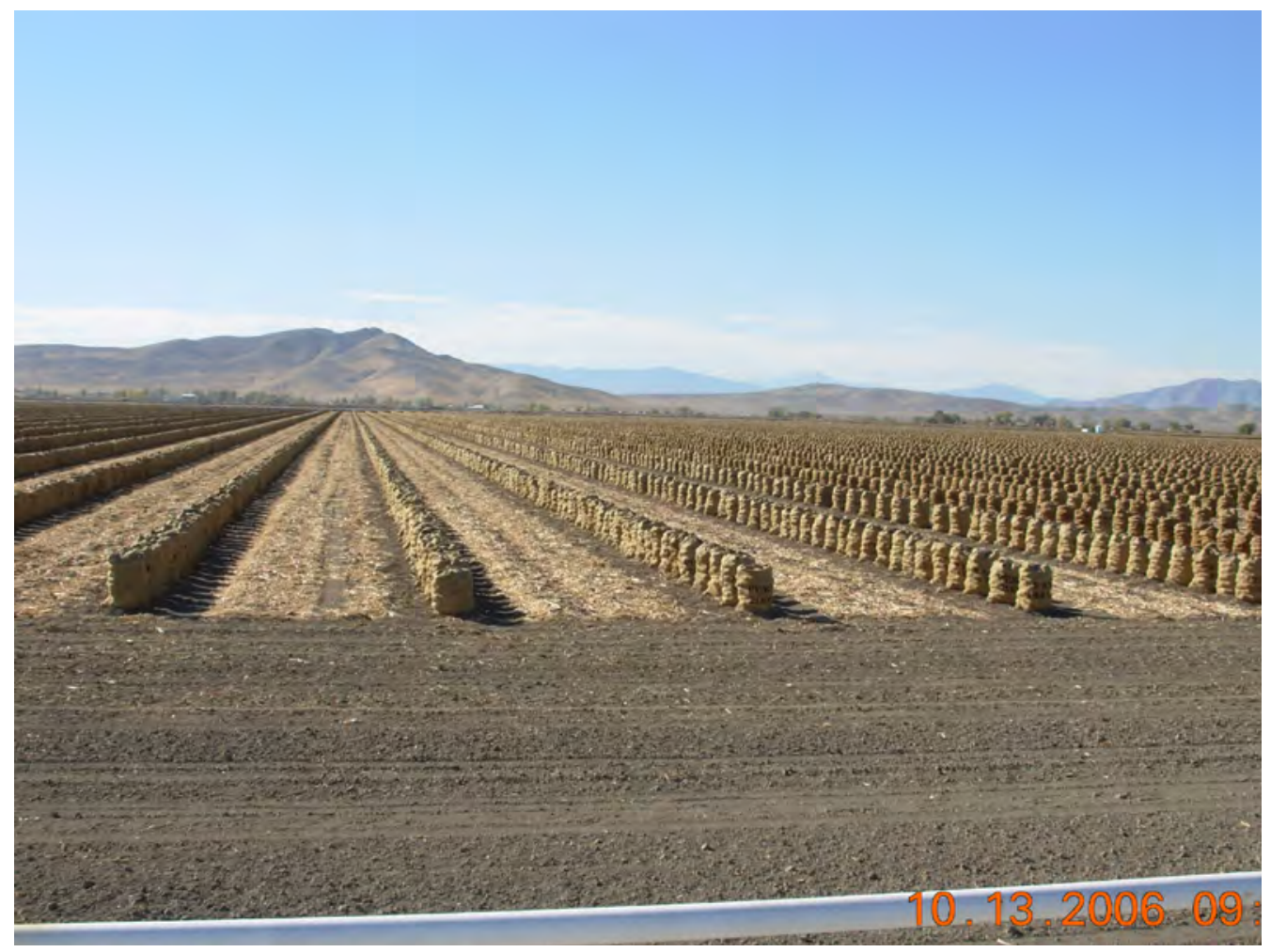

Figure 19. Sacks filled with onions during the 2006 autumn harvest, Pete Hendrichs Road, Mason Valley, Nevada. (Photograph taken by Thomas J. Lopes, October 13, 2006.)

\section{Population}

The population in the Walker River basin in 2000 was 18,682 (GeoLytics, Inc., 2001). Yerington, Nev., the Lyon County seat, is the largest town in the basin with a population of 3,257 (Hardcastle, 2006). Mason Valley, which includes Yerington, has a total population of 9,886 and Smith Valley has a total population of 1,788. Hawthorne, Nev., the Mineral County seat, has a population of 2,931. Schurz, Nev., is the only town on the Reservation and has a population of 721. Most of the population depends on agriculture to support their livelihood. Other major employers are the Army Depot, government, and mining. The towns of Topaz Lake, Nev. (population 2,128), Bridgeport, Calif. (population 837), and Walker Lake, Nev. (population 391), depend on outdoor recreation and tourism.

\section{Previous Investigations}

\section{Paleohydrology}

Walker Lake is a remnant of Lake Lahontan, a pluvial lake that occupied much of western Nevada from the Pliocene through Pleistocene. Other remnants of Lake Lahontan include Pyramid Lake, Honey Lake, and the Carson Sink. During the middle Pleistocene (650,000 years ago), Lake Lahontan reached an altitude of about 4,600 ft (Reheis and others, 2002). Lake Lahontan submerged present-day Mason Valley; Reno, Nev.; part of Carson City, Nev.; and was about 750-ft deep at present-day Walker Lake. The middle Pleistocene lake-surface elevation was about 240 - $\mathrm{ft}$ higher than the highstands of the late Pleistocene, which ended about 12,000 years ago (Reheis and others, 2002). During the middle Pleistocene, Lake Russell is believed to have overflowed from the Mono Basin into the Walker River basin through Anchorite Pass (Reheis and others, 2002).

Walker Lake became isolated from the rest of Lake Lahontan when the water level fell below 4,270 ft, (Benson and Thompson, 1987). About 45,000-50,000 years ago during the late Pleistocene, Walker Lake rose above $4,270 \mathrm{ft}$ and spilled through Adrian Gap into the Carson River basin. About 20,000 years ago, Lake Lahontan was at an altitude of about 4,150 ft for 3,500 years in the Smoke Creek-Black Rock, Pyramid, and Winnemucca subbasins (Benson and Thompson, 1987). Lake Lahontan dropped to about 4,070 ft in these subbasins by 16,000 years ago and Walker Lake desiccated. Walker Lake quickly rose starting 15,000 years ago, was above $4,270 \mathrm{ft}$ by 14,000 years ago, and Lake Lahontan again became a single body of water. Walker Lake was at a maximum altitude of about 4,360 ft from 13,500 to 12,500 years ago, then fell at least $330 \mathrm{ft}$ at the end of the Pleistocene (Benson and Thompson, 1987). 
Multidecadal and multicentennial droughts occurred throughout the Holocene in Nevada and northern California (Benson and others, 2002). During the early and middle Holocene, Walker Lake probably was a shallow (3 ft), ephemeral playa that at times desiccated or flooded. The lake probably was dry 5,300-4,800 years ago and 2,7002,100 years ago (Benson and Thompson, 1987; Benson and others, 1991). The lake level was relatively high 4,800-2,700 years ago, 1,250 years ago, and during the past 300 years (Benson and others, 1991).

Desiccation and flooding of Walker Lake during the late Holocene may not be due to climate change. Desiccation is thought to have occurred when the Walker River meandered into Adrian Valley and flowed into the Carson River basin, and sudden flooding occurred when the Walker River meandered back into the lower Walker River basin. Two of the more recent diversions of the Walker River into the Carson River basin are believed to have occurred 1,500-1,000 years ago and 500-300 years ago (Adams, 2004). The lake level fluctuated several times by about $170 \mathrm{ft}$ during the past 2,000 years (Adams, 2007), but the current (2008) level of Walker Lake $(3,930.6 \mathrm{ft})$ is the lowest during this period.

\section{Historical Hydrology}

Water budgets for the lower Walker River basin and Walker Lake have been computed by Harding (1965), Everett and Rush (1967), Rush (1970), Schaefer (1980), Milne (1987), and Thomas (1995). In addition, the State of Nevada documented the history of the Walker River basin and its water issues (Horton, 1995), summarized streamflow, lake, and reservoir gaging records (Pahl, 1997), summarized surface-water irrigation diversions (Pahl, 2000a), and computed a surface-water budget for the Walker River basin (Pahl, 2000b). For this report, only information on lake levels, hydrologic setting, surface-water/groundwater interactions, and groundwater-flow directions of the lower Walker River basin were summarized in chronological order of the reports.

The first hydrologic study of Walker Lake was done by Russell (1885). In 1882, Walker Lake was about $25.6 \mathrm{mi}$ long from north-to-south, 4.5-5 mi wide east-to-west, and had an estimated surface area of $95 \mathrm{mi}^{2}$ (60,800 acres). Large parts of the central and western portions of the lake had a uniform depth of $224 \mathrm{ft}$ with a maximum depth of $225 \mathrm{ft}$. At the northern end of the lake, partially submerged dead trees indicated the lake had recently risen $4-5 \mathrm{ft}$.

Russell (1885) described lake sediments as a fine-grained, black mud that smelled of hydrogen sulfide in many places. Two water samples were collected where the lake was 224-ft deep. Samples at 1-ft and 215-ft depths had virtually the same dissolved-solids concentrations (2,516 and 2,488 mg/L, respectively). Sodium was the predominant cation, and there were about equal percentages by weight of sulfate, chloride, and carbonate species. Precipitation of calcium carbonate was evident from the tufa that cements sand and gravel and rosetteshaped masses along the shore.

Harding (1965) described the hydrology, quantified water-budget components, and characterized variations in inflow to selected closed-basin lakes in the Great Basin, including Walker Lake. Observations of closed-basin lakes had been recorded since the first expeditions into the Great Basin in the 1840s. A main purpose of Harding's work was to compile these early, fragmented records before they became lost. Harding (1965) determined that early records for Walker Lake are less complete compared to other closed-basin lakes.

The earliest record was made by E.M. Kern who traveled around Walker Lake in 1845. Kern stated in his journal that Walker Lake was $22 \mathrm{mi}$ long and 11 or $12 \mathrm{mi}$ wide. Harding (1965) used this description and Russell's (1885) map to estimate that the lake altitude was about 4,035 ft in 1845 . Harding (1965) noted that Kern's width is "much in excess of the actual width" of Walker Lake, which makes Kern's description and Harding's estimate questionable. Other closed-basin lakes were at relatively low levels at this time but, according to Harding, "it is improbable that Walker Lake rose" about $30 \mathrm{ft}$ to reach his estimate of the 1861 lake altitude (table 3).

Harding (1965) used a report by the U.S. Indian Service (now the U.S. Bureau of Indian Affairs) that described flooding of the Indian Agent's house in 1861 and 1868 to estimate the altitude of Walker Lake. Presumably, Harding knew the location and altitude of the house and attributed the flooding to a high lake level. However, Rush (1970) stated that the house was in the area of Weber Reservoir and probably was flooded by the Walker River during spring runoff. Also, figure 44 of Harding (1965) indicates that flooding occurred in 1862 and 1868. These inconsistencies make Harding's estimates of lake altitude prior to Russell's (1885) measurement questionable, so they were not used in figure 3 of this report.

Table 3. Altitude of Walker Lake, Nevada, from 1845 to 1928.

[Altitudes estimated from Harding (1965), figure 44]

\begin{tabular}{llll}
\hline Year & $\begin{array}{c}\text { Altitude } \\
\text { (feet) }\end{array}$ & Year & $\begin{array}{c}\text { Altitude } \\
\text { (feet) }\end{array}$ \\
\hline 1845 & 4,035 & 1910 & 4,075 \\
1861 & 4,065 & 1919 & 4,074 \\
1862 & 4,082 & 1923 & 4,067 \\
1868 & 4,089 & 1924 & 4,064 \\
1878 & 4,088 & 1925 & 4,062 \\
1903 & 4,075 & 1927 & 4,055 \\
1906 & 4,080 & 1928 & 4,052 \\
\hline
\end{tabular}


E.W. Kronquist, an engineer for the U.S. Indian Service who worked in Schurz, Nev., for 20 years, found support for other lake-level estimates used by Harding (1965). Kronquist provided these estimates to Harding in the 1930's. These estimates were assumed to be reliable so they were used in figure 3 of this report.

Harding (1965) stated that the bottom of Walker Lake is at an altitude of about 3,860 ft, which is $11 \mathrm{ft}$ higher than the lowest altitude measured by Lopes and Smith (2007). Harding added the lake depth of $225 \mathrm{ft}$ (Russell, 1885), which was not measured at the deepest point, to $3,860 \mathrm{ft}$ to estimate the 1882 lake altitude was 4,085 ft. Rush (1970) incorrectly stated that Harding's estimate was 4,086 ft. Rush (1970) used his bathymetric data and Russell's (1885) depth measurement to estimate that the 1882 lake altitude was $4,083 \mathrm{ft}$. The same approach was used by Lopes and Smith (2007) who estimated that the 1882 lake altitude was $4,082 \mathrm{ft}$.

Harding (1965) estimated the evaporation rate (E) for selected closed-basin lakes as a residual of a water budget. These estimates have had a long-lasting effect on evaporation estimates in the Great basin (Allander and others, 2009). Based on the topography and geology, Harding (1965) assumed that groundwater does not flow between adjacent basins and that evaporation is the only outflow from closedbasin lakes. Harding (1965) also assumed that groundwater discharge to closed-basin lakes is negligible, so the rate actually is evaporation less groundwater discharge $\left(\mathrm{E}_{\mathrm{e}-\mathrm{gw}}\right)$. The annual volume of water that evaporates less groundwater discharge $\left(\mathrm{V}_{\mathrm{e}-\mathrm{gw}}\right)$ is:

where

$$
\mathrm{V}_{\mathrm{e}-\mathrm{gw}}=\mathrm{V}_{\mathrm{sw}}+\mathrm{V}_{\mathrm{ppt}}+\Delta_{\mathrm{s}}
$$

$\mathrm{V}_{\mathrm{sw}}$ is the annual volume of streamflow into the lake;

$\mathrm{V}_{\mathrm{ppt}}$ is the annual volume of precipitation on the lake; and

$\Delta_{\mathrm{S}}$ is the annual change in lake storage (positive for a declining lake).

$\mathrm{E}_{\mathrm{e}-\mathrm{gw}}$ was estimated by dividing $\mathrm{V}_{\mathrm{e}-\mathrm{gw}}$ by the lake surface area.

Harding (1965) considered Walker, Pyramid, and Winnemucca Lakes to be the best locations to estimate $E_{e-g w}$ because they have one primary source of inflow or no inflow in the case of Winnemucca Lake. Harding's estimate of $4.10 \mathrm{ft} / \mathrm{yr}$ for $\mathrm{E}_{\mathrm{e}-\mathrm{gw}}$ at Walker Lake compared well to estimates at Pyramid Lake (4.02 ft/yr) and Winnemucca Lake (3.98 ft/yr), which have a climate and altitude similar to Walker Lake.

Harding's estimate is biased low, partly because there is appreciable groundwater discharge to Walker Lake (Everett and Rush, 1967; Schaefer, 1980). By 1965, Walker Lake had fallen $110 \mathrm{ft}$ since the first measurement by Russell (1885). The declining lake level would increase the groundwater gradient adjacent to the lake, induce drainage from aquifer storage, and result in a declining water table. Groundwater discharge is a small fraction of the volume evaporated when the lake level is high, so assuming subsurface inflow is negligible may be reasonable. However, as the lake declines, groundwater discharge becomes a larger percentage of $E$ and needs to be taken into account.

Allander and others (2009) used the energy-budget method to estimate an $E$ rate of $5.0 \mathrm{ft} / \mathrm{yr}$, which is $0.9 \mathrm{ft} / \mathrm{yr}$ more than Harding (1965). The average surface area was 32,330 acres during the work by Allander and others (2009). About 29,000 acre-ft/yr (32,330 acres $\times 0.9 \mathrm{ft})$ of groundwater discharge is needed for Harding's estimate of $E_{e-g w}$ to equal E estimated by Allander and others (2009). This is almost 3 -times more than previous estimates of groundwater discharge and is likely too high.

During the computation of water budgets for the lower Walker River basin, it became apparent that energy-budget method over-estimated the E rate. Lopes and Allander (2009) estimated an average $E$ rate of $4.3 \mathrm{ft} / \mathrm{yr}$, which is 14 percent less than Allander and others' (2009) estimate and 5 percent more than Harding's (1965) estimate. The estimate of $5.0 \mathrm{ft} / \mathrm{yr}$ could be because the energy-budget method assumes closure in the energy budget. However, energy budgets typically do not close and have residuals of about 10 to 30 percent (Foken, 2008).

Everett and Rush (1967) stated that groundwater in the lower Walker River basin is from subsurface inflow from Mason Valley, infiltration of streamflow along the Walker River, infiltration of precipitation, and induced recharge from diverted water. Groundwater discharge primarily occurs by ET from phreatophytes and bare soil with much less discharge by pumpage for irrigation, municipal, domestic, and stock use (Everett and Rush, 1967). Everett and Rush also described a $40-\mathrm{ft}$ decline in the water table between $1908-65$ over a $40 \mathrm{mi}^{2}$ area south of Walker Lake. The decline was attributed to drainage of the alluvial aquifer caused by the decline in lake level and is evidence that the lake and contiguous aquifers are connected hydraulically.

In addition to the bathymetry and water budget, Rush (1970) collected 28 samples to characterize the distribution of dissolved constituents in Walker Lake. Similar to Russell (1885), Rush determined that the water chemistry was nearly homogeneous and that water temperature decreased with depth. Rush (1970, fig. 7) indicates a thermocline at a depth of about $50 \mathrm{ft}$, which is similar to Lopes and Smith (2007) who measured a thermocline at a depth of $43 \mathrm{ft}$ in 2005.

Schaefer (1980) published maps showing contours of equal water-table altitude and depth to water on the Reservation. Depth to water ranged from less than $10 \mathrm{ft}$ along the Walker River to greater than $300 \mathrm{ft}$ north and east of Schurz, Nev. Water-table contours indicate a groundwater divide several miles southeast of Schurz, Nev., that separates eastward flow towards Double Spring from southerly flow towards Walker Lake. 
Schaefer (1980) used seismic reflection to estimate the thickness of alluvial sediments at selected locations north and east of Schurz, Nev. Sediments average about 1,000 ft thick and consists of alluvial and lacustrine sand, silt, and clay. Most aquifers are comprised of fine-grained material, but newly installed irrigation wells produced up to 2,500 gal/ min. Schaefer (1980) qualitatively analyzed 30 drillers' logs and estimated the specific yield of the alluvial aquifer ranges from 6 to 25 percent with an average of 14 percent. Hydraulic conductivity, estimated from specific-capacity tests for 24 wells, ranged from 1 to $90 \mathrm{ft} / \mathrm{d}$ with an average of $30 \mathrm{ft} / \mathrm{d}$. Schaefer (1980) used data on water-table altitude, sediment thickness, and hydraulic conductivity in a computer model to estimate the volume of groundwater that flows east towards Double Spring and south towards Walker Lake.

Milne (1987) estimated what the inflows and levels of Walker Lake and other lakes in the Great Basin would have been if there were no diversions to determine whether declines in lake levels were due to humans or climate change. As part of the study, Milne (1987) used the water-budget method and assumed negligible groundwater inflow to estimate $E_{e-g w}$ of $4.4 \mathrm{ft} / \mathrm{yr}$ for Walker Lake. Milne's model indicated that if the Walker River had not been diverted, then Walker Lake would have risen during the period 1882-1920 and that the 1987 level would have been near the 1882 level.

Milne's estimates for Mono Lake were similar to estimates made by the Los Angeles Department of Water and Power. Mono Lake is a terminal basin that is contiguous with the southern boundary of the Walker River basin (fig. 1). Like Walker Lake, snowmelt from the Sierra Nevada is the main source of inflow to Mono Lake. Changes in the levels of these lakes should be similar because annual and decadal changes in climate affect streamflow over much larger areas than these two drainage basins (Benson and others, 2002). The Los Angeles Department of Water and Power started diverting water from the Mono Basin in 1941. Six years after diversions started, the level of Mono Lake started a rapid decline similar to Walker Lake (fig. 20). Milne's and the Los Angeles Department of Water and Power's estimates indicated that the 1987 level of Mono Lake would have been near the 1941 level if streamflow had not been diverted.

Thomas (1995) updated the water budget for Walker Lake using the 55-year period 1939-93 and previous estimates of inflow and outflow. Thomas (1995) estimated an additional 33,000 acre-ft/yr of inflow would be needed to maintain the lake at its 1994 altitude of 3,944 ft and dissolved-solids concentration of $13,300 \mathrm{mg} / \mathrm{L}$. To reduce dissolved solids to $10,000 \mathrm{mg} / \mathrm{L}, 700,000$ acre-ft would be needed to raise the lake to 3,964 ft, then 47,000 acre-ft/yr of inflow in addition to the average annual inflows would be needed to maintain the lake level. However, these estimates did not include water needed to replenish aquifer storage. Currently (2008), more than $1,100,000$ acre-ft would be needed to raise the lake to $3,964 \mathrm{ft}$.

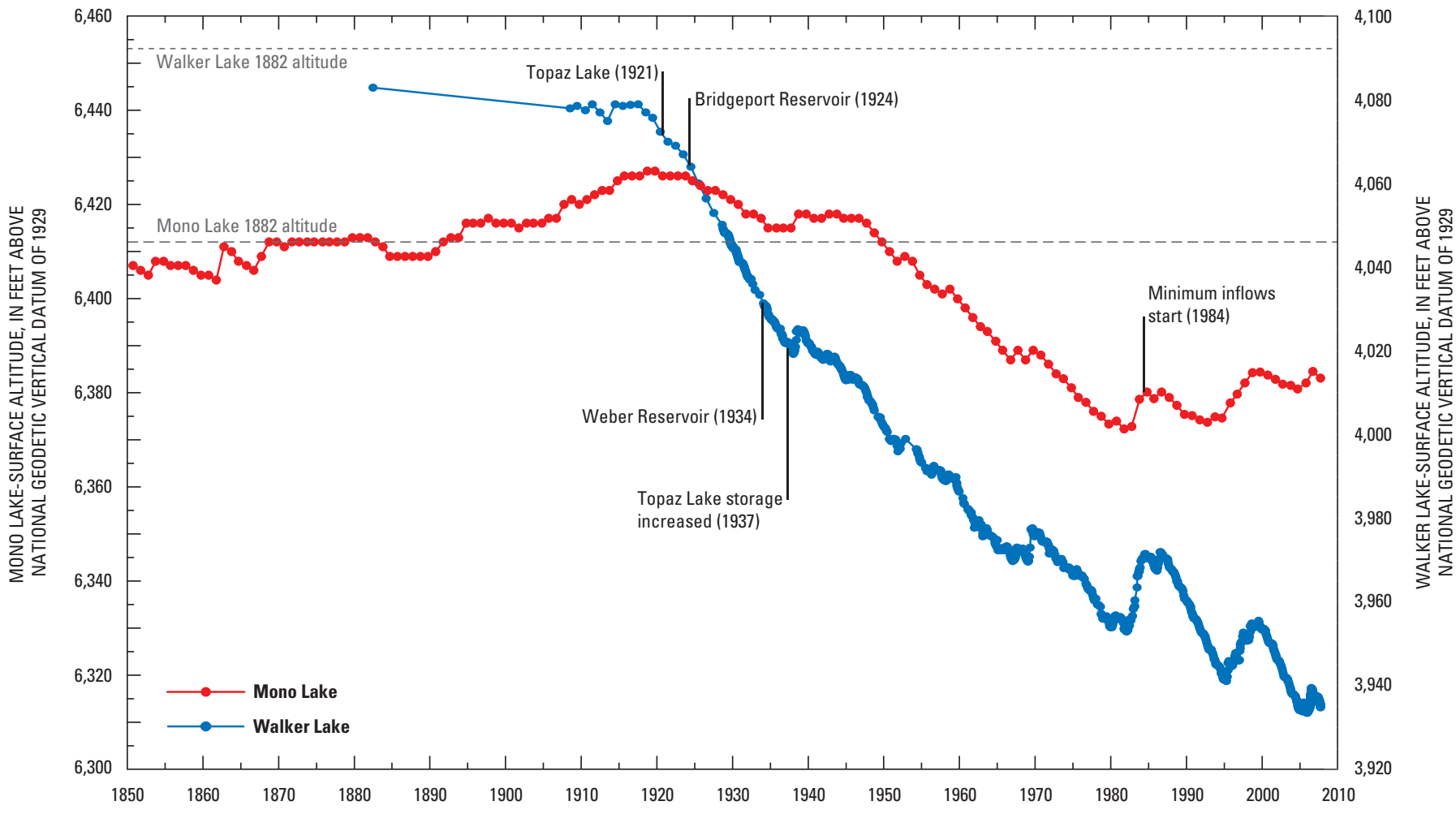

Figure 20. Lake-surface altitude of Mono Lake, California, and Walker Lake, Nevada, from 1850 through September 30, 2007. 


\section{Methods}

Data collection for this study began in February 2004 and was completed in April 2008. Data collected during each water year (begins October 1 and ends September 30 of the stated water year) were published in the respective annual data reports, which are available at http://nevada.usgs.gov. Exceptions include 2005 streamflow data from the streamflowgaging stations Walker River near Mouth at Walker Lake, Nev. (near Mouth gage, 10302025; fig. 21), Cottonwood Creek near Walker Lake, Nev. (Cottonwood Creek gage, 10302160), and Rose Creek near Walker Lake, Nev. (Rose Creek gage, 10302145), that were published in the 2006 annual data report, available at http://wdr.water.usgs.gov/wy2006/search.jsp.

\section{Surface-Water Measurements}

Currently (2008), streamflow and diversions are estimated at six gaging stations in the lower Walker River basin. The Wabuska gage (fig. 21) is an important station that measures outflow from Mason Valley and inflow to the lower Walker River basin. This station started operation in 1902 and has a complete record since 1945. The streamflow-gaging station Walker River above Weber Reservoir near Schurz, Nev. (10301600, known as the Cow Camp gage) started operation in 1977. The Cow Camp gage was discontinued in 1982, then was restarted and has been operating continuously since 1994 . Data from the Cow Camp gage should be used with caution because streamflow has been observed bypassing the gage, especially at high flows. The streamflow-gaging station Walker River above Little Dam near Schurz, Nev. (Little Dam gage, 10301745), started operation in 1995, was discontinued in 2001, and was restarted in 2004. The name of the Little Dam gage is misleading. The gage shelter is upstream from Little Dam but instruments measure flow downstream from the dam. The diversion gaging stations Canal No. 2 above Little Dam near Schurz, Nev. (Canal No. 2 gage, 10301742), and Canal No. 1 below Little Dam near Schurz, Nev. (Canal No. 1 gage, 10301755), have been operating continuously since 1996 . The name of the Canal No. 1 gage also is misleading. Diversions into both Canal No. 1 and Canal No. 2 are above Little Dam. The streamflow-gaging station Walker River at Lateral 2-A siphon near Schurz, Nev. (Lateral 2-A gage, 10302002), has been operating continuously since 1994. There are no irrigation returns downstream from the Lateral 2-A gage and tributary inflow reaches the river only during extremely high runoff events.

As technology has developed, continuous streamflow has been estimated using different methods. However, methods have been based on the same principal. A device, such as a float or bubbler, is installed in the river to measure stream stage (Kennedy, 1983). Stage measurements are recorded at 15-min intervals on another device, such as a paper chart or data logger. A technician manually measures streamflow using pygmy current, AA current, or acoustic Doppler velocity meters at different stages and develops a stagedischarge rating. Technicians typically measure streamflow every 6 weeks because the channel geometry can change or ice can form and affect the stage-discharge relation. The stage-discharge rating is applied to the 15-min stage record to estimate mean daily, monthly, and annual streamflow. All gages in the Walker River basin are equipped to automatically transmit preliminary data for public access on the web site http://nevada.usgs.gov.

Stage recorders continuously monitor water levels in Weber Reservoir and Walker Lake. Prior to October 2004, the level of Walker Lake was measured each month by tape down from a reference point at a known elevation. Water levels are used with storage-volume and surface-area ratings to estimate storage volumes and surface areas (Rush, 1970; Katzer and Harmsen, 1973; Lopes and Smith, 2007).

Intermittent discharge measurements were made at the streamflow-gaging station Walker River at Powerline Crossing near Schurz, Nev. (Powerline gage, 10302005, fig. 21), and the near Mouth gage about every 2 weeks from October 2004 to September 2007. From 1994 to 2004, discharge measurements were made at these two sites every 2 weeks around April through October. The Powerline and near Mouth gages are downstream from the Lateral 2-A gage, the last continuous gage in the basin. The channel is too unstable to continuously measure streamflow downstream from the Lateral 2-A gage. However, a pressure transducer was installed for this study at the near Mouth gage and recorded continuous streamflow from October 1, 2004, through May 16, 2006. On May 17, 2006, high flows flushed the pressure transducer into Walker Lake, which ended efforts to continuously monitor streamflow along this reach.

Synoptic-discharge measurements were made during low flow to identify losing or gaining reaches of the river. Synoptics were done during late autumn to late winter when streamflow and ET were low and detection of groundwater discharge and infiltration is most likely. During the 3 days prior to the March 2004 synoptic, discharge at the Wabuska gage decreased from 38 to $24 \mathrm{ft}^{3} / \mathrm{s}$, varied from 16 to $20 \mathrm{ft}^{3} / \mathrm{s}$ prior to the March 2005 synoptic, and varied from 63 to $70 \mathrm{ft}^{3} / \mathrm{s}$ prior to the November 2005 synoptic. The March 2004 synoptic included measurements of discharge and chemistry from the streamflow-gaging stations West Walker River near Hudson, Nev. (Hudson gage, 10300000), and East Walker River near Strosnider Ditch near Mason, Nev. (Strosnider gage, 10293500), to the near Mouth gage. The March 2005 synoptic included measurements of discharge and chemistry from the Wabuska gage to the Cow Camp gage. The November 2005 synoptic was for measurement of discharge from the northern boundary of the Management Area to the Wabuska gage. A synoptic in January 2005 was for measurement of radon from the Wabuska gage to the Cow Camp gage. Instantaneous discharge at the Wabuska gage varied from 24 to $30 \mathrm{ft}^{3} / \mathrm{s}$ prior to this synoptic. 


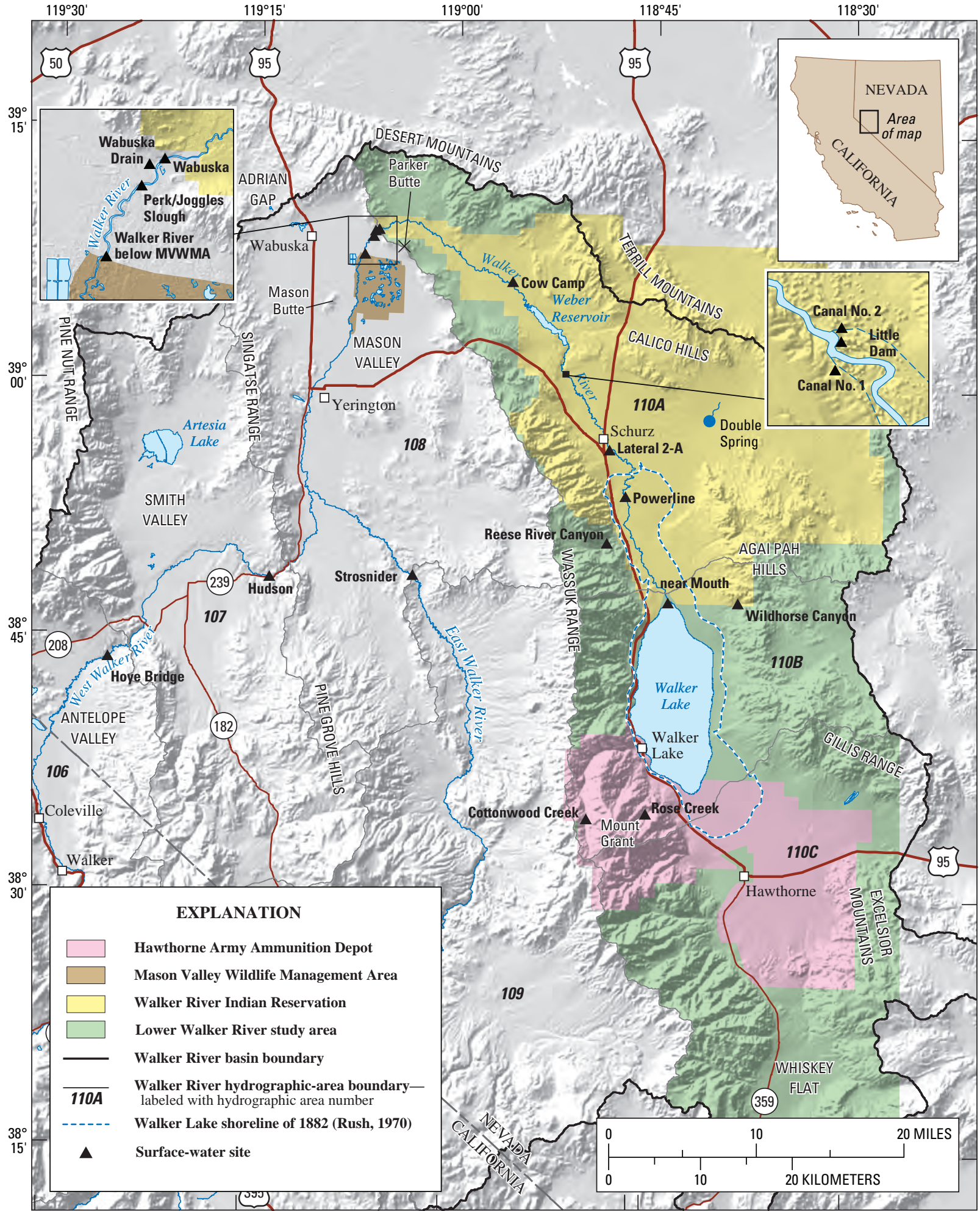

Base from U.S. Geological Survey digital data, 1:24,000 and 1:100,000, 1978-88. Walker Lake

average lake altitude of $3937.5 \mathrm{ft}$ or November 2006, Projection. Universal Transverse

Mercator, Zone 11, North American Datum of 1983. Shaded-relief base from 90-mete

Shuttle Radar Topography Mission digital data, 2000

Figure 21. Locations of selected surface-water sites in the Walker River basin, Nevada. 


\section{Groundwater Measurements}

Twenty-six monitoring wells were installed for this study at selected locations along the lower Walker River, east and northeast of Walker Lake, near ET stations, and northwest and northeast of Schurz, Nev. (fig. 22). Monitoring wells were installed to obtain data on groundwater levels, aquifer lithology and hydraulic properties, aquifer response to streamflow, changes in groundwater storage due to fluctuating lake levels, and groundwater chemistry. All monitoring wells were constructed of 2-in. PVC with 5-20 ft of 0.02 -in. slotted screen. The annular space around wells was first filled with native sand or 0.25 -in. silica gravel to about $5 \mathrm{ft}$ above the screen and then neat cement or bentonite grout to land surface. Wells were developed with varying degrees of success by airlifting and pumping.

Eighteen of the 26 wells were installed at depths of less than $50 \mathrm{ft}$ using a hollow-stem auger during January and February 2005. Three wells were installed to define the plane of the water table near the river at streamflow-gaging stations and at the mouth of the Walker River. The three monitoring wells at the mouth of the Walker River, not shown in figure 22, were flushed into Walker Lake during the 2005 spring runoff. Two of the wells were replaced, but these wells also were flushed into Walker Lake during the 2006 spring runoff. This ended efforts to monitor groundwater levels at the mouth of the Walker River.

Eight of the 26 wells were installed using a mud-rotary rig during February and March 2007 at four sites east and northeast of Walker Lake and northwest and northeast of Schurz, Nev. At each site, one well was completed just below the water table and one well was installed about $50-100 \mathrm{ft}$ below the water-table well to measure vertical gradients. The water-table well northwest of Schurz, Nev., not shown in figure 22, became plugged with grout so water levels and chemistry could not be measured.

From 2004 through 2006, groundwater levels were measured in about 200 wells from Smith Valley to Hawthorne, Nev. Most of these wells were existing irrigation and domestic wells. Measurements were made during February and March before the irrigation season and during late October through early December after irrigation. Groundwater levels were measured using either a steel or electric tape with $0.01-\mathrm{ft}$ increments.

Groundwater levels were measured monthly in a subset of wells along the Walker River, except for an 8-month period when wells could not be accessed. Pressure transducers and thermistors also were used to continuously measure groundwater levels and temperatures at 15-min intervals. Pressure transducers and thermistors were installed in monitoring wells at the Willow, Lateral 2-A, and Powerline sites.
Depth to water from land surface was calculated by subtracting the height of the measuring point from the measurement and water-table altitude was calculated by subtracting depth to water from land-surface altitude. Digital elevation models from Lidar and remote sensing surveys, described by Lopes and Smith (2007), were used to determine the land-surface altitude for the lower Walker River basin and northern Mason Valley. Lidar has an accuracy of about $0.5 \mathrm{ft}$. Remote sensing consistently overestimated altitude by an average of $3 \mathrm{ft}$ compared to Lidar. Land-surface altitude of most wells in Smith Valley and Mason Valley was estimated from topographic maps and had an accuracy of 10-20 ft. Contours of equal water-table altitude were hand drawn using only autumn 2006 data because groundwater-flow directions changed little during the study.

Hydraulic conductivity and transmissivity of alluvial aquifers in the lower Walker River basin were estimated with slug and aquifer tests, respectively (data on file at the Nevada Water Science Center). South of Walker Lake, slug-test data collected in 1979 from seven monitoring wells on the Army Depot were re-analyzed for this study. The wells were installed in 1978 as part of a contaminant transport study (Van Denburgh and others, 1996). Well construction, lithologic logs, slug-test procedures, and data are in the archive records of the USGS Nevada Water Science Center.

The Army Depot monitoring wells were installed about $1 \mathrm{mi}$ south of Walker Lake along lines parallel to the 1979 shoreline and perpendicular to the direction of contaminant movement. Wells were spaced 500-1,000 ft apart, 32-37 ft deep, and with $10-\mathrm{ft}$ screens centered between $15 \mathrm{ft}$ and $20 \mathrm{ft}$ deep. Aquifer lithology was fine to coarse sands interbedded with thin strata of clay and occasional gravel. A cable-tool rig was used to drill boreholes and the well screens were packed with native material or commercial sand and gravel. Wells were sealed with clay-sized sediment and capped with cement.

A type of pressure transducer and a datalogger were used to measure water-level response to the rapid removal of a submerged float. The float was made from a 2 -in. diameter, 7.97-ft long PVC pipe that had a measured displacement of $2.9 \mathrm{ft}$ of water in a 3-in. well. Each well was slugged three to four times except well 13, which had a single test. Original water-level data, printed on rolled receipt-type paper, were scanned into bitmap image documents, and a character recognition program was used to convert the scanned image into digital data. Digital data were reviewed for accuracy and errors in character recognition were corrected.

Data were originally analyzed using the method of Cooper and others (1967) and re-analyzed using a spreadsheet developed by Halford and Kuniansky (2002). This spreadsheet mainly uses the KGS method (Butler and others, 2003), which is a modification of the method of Bouwer and Rice (1976). 


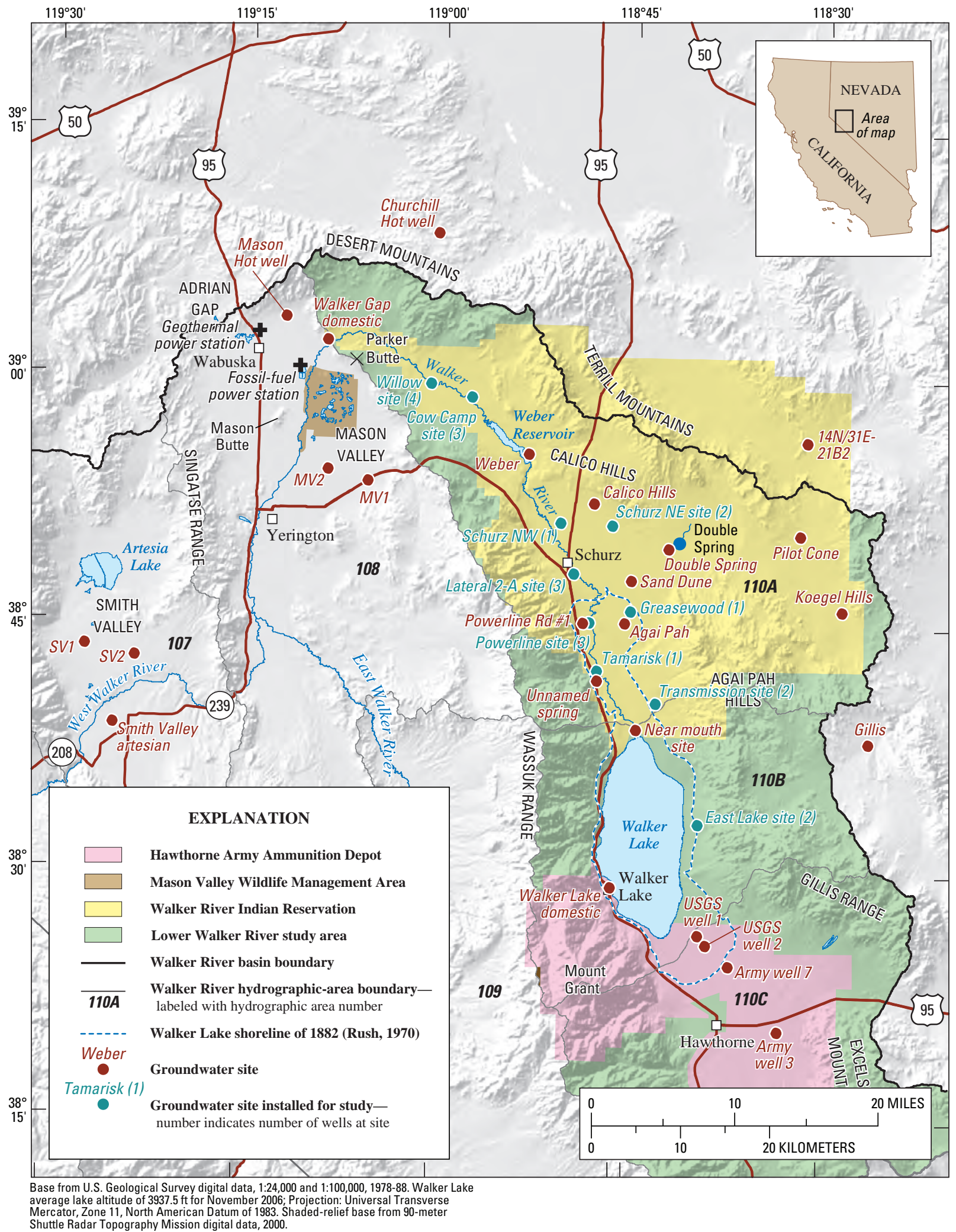

Figure 22. Locations of selected wells in the Walker River basin, Nevada. 
Slug tests were performed on 19 of the 26 monitoring wells installed for this study. Slug tests were done using a pressure transducer, datalogger, and two methods to slug the wells. The preferred method was lowering and raising a solid slug to simulate adding or removing water. The solid slug was made of a 62 -in. long, 1 -in. diameter steel pipe that was suspended on a steel tape. The solid slug was lowered rapidly into the water to do a falling head test (Halford and Kuniansky, 2002). After the water level stabilized, the solid slug was removed rapidly to do a rising head test. Rising and falling head tests were repeated once to ensure reproducibility of data.

The second method was pouring a known volume of water into the well. A slug of water was added to wells with less than $7 \mathrm{ft}$ of water where the solid slug could not be used or where the solid slug did not fit in the well. A water slug also was added following the solid slug to compare the two methods. The water slug test was repeated three times in each well using $0.23,0.45$, and 0.90 gal of water of water. When the water-slug method followed the solid-slug method, a single slug of 0.23 gal was used. Depending on the depth to water, the water slug took from 4 to 31 seconds to completely drain down the inside of the well casing. Water-slug and solid-slug tests had similar results despite the slow delivery time.

Water levels were measured with a resolution of $0.01 \mathrm{ft}$ and at $0.0125,0.5$, or 1 -second intervals, depending on the time water levels took to stabilize after the initial slug. Preliminary estimates of hydraulic conductivity were made in the field using a short version of the KGS method (Halford and Kuniansky, 2002) to ensure data reliability. The full version of the KGS method was used for the final estimates. The estimate was the hydraulic conductivity that best fit the two rising and two falling head tests.

The Double Spring well, an artesian stock well about $6.5 \mathrm{mi}$ east of Schurz, was drilled using a cable-tool rig in 1948. The 102-ft borehole has unperforated steel casing from land surface to $50 \mathrm{ft}$ and the remainder of the hole was left open. The well was fitted with piping so artesian flow could fill a nearby tank. The piping was no longer functional due to a split in the casing and numerous bullet holes and subsequently was cut off to do an aquifer test.

The aquifer test was done by measuring the head response to repeated opening and closing of the artesian discharge. To accomplish this, a special packer was constructed that allowed artesian discharge to be controlled. The packer was placed over the well casing with the discharge valve open. The inner-tube seal of the packer was inflated until there was no leakage between the packer and the base of the well casing, then the discharge valve was closed. The packer was fitted with a vented pressure transducer to measure head pressure inside of the packer every 2 seconds. The aquifer test was done by closing the discharge valve until pressure had stabilized, then opening the valve and measuring head pressure and discharge. Discharge initially was measured with a flow meter, but the meter malfunctioned so discharge was measured with a calibrated bucket and stopwatch.
Data were analyzed using the principles of Theis (1935; Keith Halford, Hydrologist, Nevada Water Science Center, written commun., May 23, 2008). The analysis fits the pressure recovery curve after the discharge is closed.

A multiple-well aquifer test was done 4 mi south of Schurz using a 16-in. diameter irrigation well and two 2-in. diameter monitoring wells. The irrigation well was drilled through multiple strata of sand, gravel, and clay, is $375 \mathrm{ft}$ deep, and perforated from 136 to $298 \mathrm{ft}$ and from 328 to $375 \mathrm{ft}$. The well supplies water to a center pivot, which was operated during the test to minimize recharge of pumped water. Construction and lithologic logs are not available for the monitoring wells, but sounding indicated wells are $118 \mathrm{ft}$ and $122 \mathrm{ft}$ deep.

Water levels in the monitoring wells were measured with calibrated pressure transducers for 2 weeks prior to the aquifer test to characterize fluctuations due to changes in atmospheric pressure. Just prior to starting the test, depth to water in the irrigation and monitoring wells was measured with an electric or steel tape. During the test, water levels in monitoring wells were measured continuously using pressure transducers. Depth to water in the irrigation well was measured occasionally during the first hours of the test, but measurements were discontinued due to interferences.

The test was done from April 27-29, 2008, for a total of 40.3 hrs. Discharge, measured using an ultrasound flow meter, initially was $1,600 \mathrm{gal} / \mathrm{min}$ and quickly fell to $1,350 \mathrm{gal} / \mathrm{min}$ as drawdown increased. Discharge gradually decreased to 1,250 gal/min on April 28, 2008. The ultrasound meter failed during the test, so a constant rate of $1,300 \mathrm{gal} / \mathrm{min}$ for data analysis was used. MODOPTIM (Halford, 2006) and MODFLOW-96 (McDonald and Harbaugh, 1988; Harbaugh and McDonald, 1996) were used to make a two-dimensional, radial-transient groundwater flow model that simulated the aquifer test and estimated aquifer properties.

\section{Seismic Refraction}

Seismic refraction is a method of estimating the thicknesses of strata in alluvium and depth to bedrock with minimal disturbance to the environment (Haeni, 1986). Strata that can be estimated include unsaturated alluvium, saturated alluvium, and semi-consolidated alluvium. Semi-consolidated alluvium overlies bedrock and could be compacted coarsegrained sediments or clay. Thickness and depth are estimated from the time it takes for a compressional sound wave (seismic wave) to travel to and refract off each stratum to geophones on the surface. Seismic velocities depend on the characteristics of each stratum including mineralogy, grain size, water content, density, cementation, and pressure. Seismic refraction requires that deeper strata have greater velocities, which generally is the case with alluvial basins in Nevada (Berger and others, 2001, p. 8). 
Seismic lines consisted of 12 geophones with $100-\mathrm{ft}$ spacing between each phone. Seismic waves were generated by detonating $0.33-5 \mathrm{lbs}$ of ammonium nitrate $3-10 \mathrm{ft}$ below land surface. A sequence of 5-10 detonations were placed $100-7,000 \mathrm{ft}$ from the last geophone or near the center of the line. Larger detonations were placed deeper in the ground with increasing distance from the last geophone. Two consecutive detonations were placed at the same distance but on opposite ends of the seismic line except for lines south of Walker Lake where access restrictions limited reversing detonations to within $1,000 \mathrm{ft}$ of the last geophone. Strata detected from detonations greater than $1,000 \mathrm{ft}$ that were not detected with closer, reversed detonations were assumed to be deep, horizontal strata.

Three seismic lines were done in the Double Spring area and two lines were done south of Walker Lake on the Army Depot (fig. 23). Seismic velocities ranged from 840 to $2,400 \mathrm{ft} / \mathrm{s}$ in unsaturated sediments, from 5,400 to $6,300 \mathrm{ft} / \mathrm{s}$ in saturated sediments, and from 7,100 to 8,500 ft/s in semiconsolidated alluvium. Bedrock was assumed to have a velocity of 11,000 ft/s south of Walker Lake and a velocity greater than 8,000 ft/s in the Double Spring area.

A preliminary analysis of data was done in the field to determine the adequacy of first-arrival seismic waves and whether bedrock had been detected. Final interpretation was done in the office using SIPT2 software (Rimrock Geophysics, Inc., 1995). SIPT2 runs an inversion algorithm that uses the delay-time method (Pakiser and Black, 1957) to obtain a first-approximation depth model. The first approximation was refined using ray-tracing and adjustment iterations to minimize differences between field-measured and simulated arrival times.

\section{Chemical Sampling}

Synoptic sampling of streamflow for major ions and isotopes was done concurrently with synoptic-discharge measurements of Walker River during March 2004 and March 2005. A synoptic survey using radon as a tracer of groundwater discharge was done between the Wabuska and Cow Camp gages in January 2005. Additionally, groundwater samples were analyzed for major ions and isotopes to aid in interpretation of surface-water samples and to use geochemical methods of interpreting groundwater flow. A total of 19 wells and 1 spring were sampled in April 2005, August 2006, and July 2007. Samples also were collected from Weber Reservoir and Walker Lake in August 2006 for comparison to stream and groundwater samples. Pore-water and water-column samples were collected from Walker Lake during July and August 2007 to trace groundwater discharge using isotopes.

Streamflow was monitored for $\mathrm{pH}$, dissolved oxygen, specific conductance, and temperature. Samples for major ions and isotopes were collected using a DH-81 sampler and the equal-width increment method (U.S. Geological Survey, 2006a). Aliquots from each increment were placed in a polyethylene churn splitter, thoroughly mixed, and then processed. Samples for radon-222 analysis were collected without putting a vacuum on the sample. A 0.34-fl. oz syringe with the plunger out was submerged near the centroid of the stream, filled near the sediment-water interface, and then the plunger was replaced while the syringe was still submerged. The sample was injected into a bottle with liquid scintillation cocktail. Radon samples were shipped overnight for analysis the following day.

A minimum of three well volumes were pumped prior to sampling each well, except at the Double Spring flowing well (385755118412701). Groundwater was pumped through a flow-through cell where $\mathrm{pH}$, dissolved oxygen, specific conductance, and temperature were monitored until they stabilized before samples were collected (U.S. Geological Survey, 2006a). Samples were collected directly from the flowing well and the orifice of a flowing spring.

Pore-water and water-column samples were collected at 28 sites in Walker Lake and analyzed for stable isotopes of hydrogen and oxygen. A gravity corer was used to collect cores at 22 sites. At six sites, the gravity corer could not penetrate the sandy sediments so a 2.75-in. diameter polycarbonate tube was hammered into the lake bottom. Cores range in length from 0.33 to $2.6 \mathrm{ft}$. A peristaltic pump was used to sample the water at the sediment-water interface. Then, the bottom 3-4 in. of the core was cut off, capped, and sealed with electric tape. The toluene-extraction method was used to obtain pore-water extracts. A polycarbonate Van Dorn sampler and a brass Kemmerer sampler were used to collect lake water at mid-depth, which ranged from 2.5 to $38 \mathrm{ft}$ with a mean of $20 \mathrm{ft}$. The thermocline is at a depth of $40-50 \mathrm{ft}$ (Rush, 1970; Lopes and Smith, 2007), so all mid-depth samples were from the epilimnion.

Streamflow and groundwater samples were filtered in the field using 0.45 -micron filters for analysis of dissolved constituents (Wilde and others, 2004). Unfiltered water samples were analyzed for isotopes of hydrogen and oxygen. Dissolved alkalinity was measured in the field by incremental titration. Samples for cations and uranium isotopes were preserved to $\mathrm{pH}$ less than 2 using $7 \mathrm{~N}$, ultra-pure nitric acid. Major ions, dissolved solids, and radon were analyzed at the USGS National Water-Quality Laboratory in Denver, Colo. Stable isotopes of oxygen and hydrogen in water were analyzed at the USGS Stable Isotope Laboratory in Reston, Va. Uranium isotopes were analyzed by Eberline Services in Richmond, Calif.

Concentrations of radioactive isotopes (radionuclides) are referred to as activities because analyses measure the radiation emitted from a sample rather than elemental mass. 


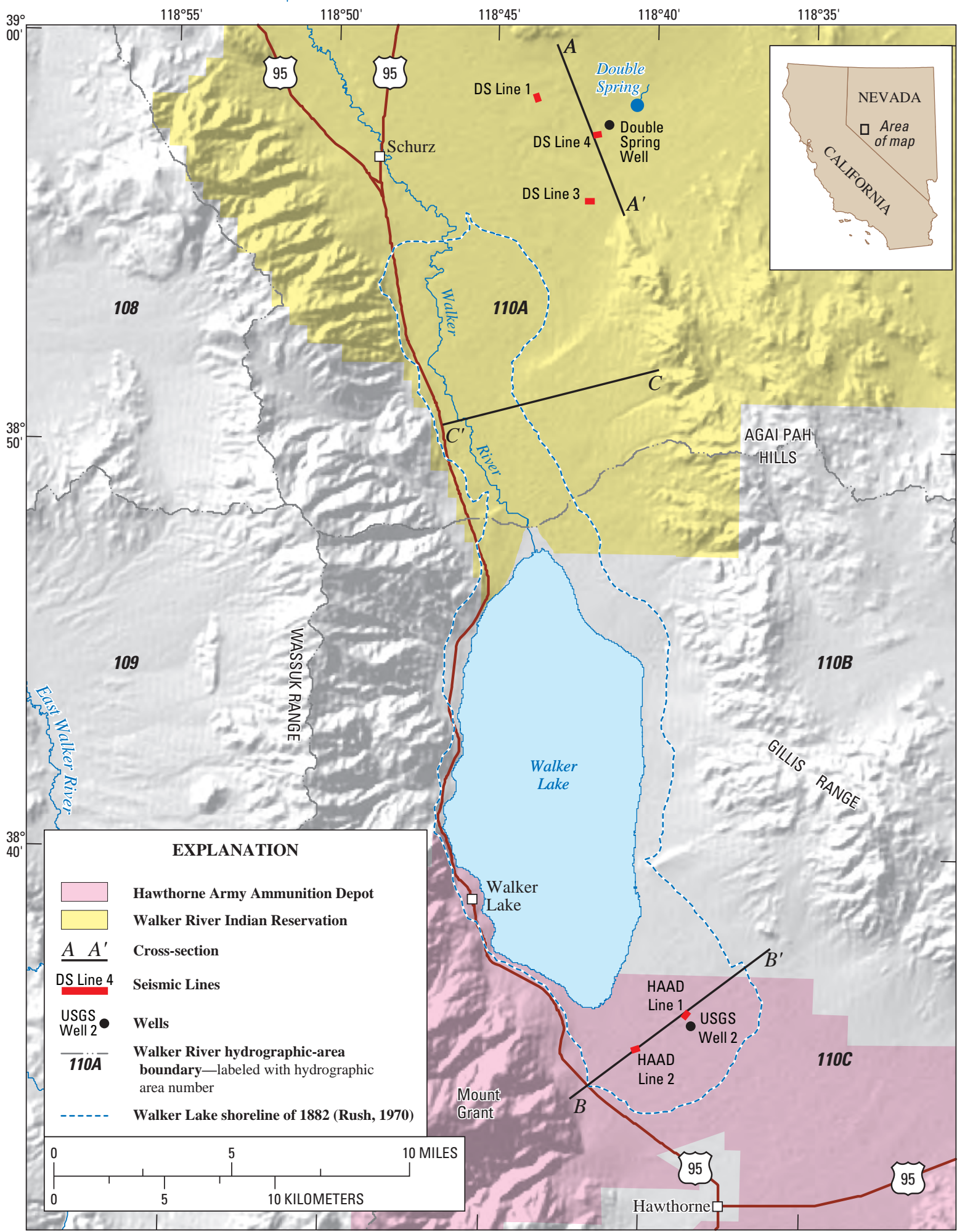

Base from U.S. Geological Survey digital data, 1:24,000 and 1:100,000, 1978-88. Walker Lake

average lake altitude of $3937.5 \mathrm{ft}$ for November 2006; Projection: Universal Transverse

Mercator, Zone 11, North American Datum of 1983. Shaded-relief base from 90-meter

Shuttle Radar Topography Mission digital data, 2000.

Figure 23. Locations of seismic-refraction lines and generalized cross sections, Walker River basin, Nevada. (DS, Double Spring; HAAD, Hawthorne Army Ammunition Depot) 
Concentrations of stable isotopes typically are measured relative to a standard in which the ratio of two isotopes is known (for example, ${ }^{2} \mathrm{H} /{ }^{1} \mathrm{H}$ ). The standard for oxygen and hydrogen isotopes is Vienna Standard Mean Ocean Water (Coplen and others, 2000). Differences from the standard are expressed by delta notation $(\delta)$ in parts per thousand $(\%$, per mil). The delta notation is computed from the equation:

$$
\delta=\left[\frac{\mathrm{R}_{\mathrm{x}}-\mathrm{R}_{\mathrm{std}}}{\mathrm{R}_{\mathrm{std}}}\right] * 1,000,
$$

where

$R_{x}$ is ratio of isotopes measured in sample, and

$R_{\text {std }}$ is ratio of isotopes in the standard.

Samples enriched in lighter isotopes relative to the standard have negative delta values. Positive delta values indicate the sample is enriched in heavier isotopes compared to the standard.

\section{Statistics}

Parametric and non-parametric statistics were used to determine if relations exist between variables. Parametric tests assume that data have a certain distribution and use parameters, such as the mean and standard deviation, to summarize information contained in the data (Helsel and Hirsch, 1992). The most common assumption is that data are normally distributed. However, environmental data often are not normally distributed. If the assumption of normal distribution is invalid, parametric tests may lead to incorrect conclusions because the tests lack sensitivity to detect real effects (Helsel and Hirsch, 1992). Non-parametric tests do not assume a certain distribution in the data. Instead of summarizing information in parameters, information is obtained directly from the data by ranking values and comparing ranks between variables (Helsel and Hirsch, 1992). Using the ranks gives less weight to outliers and is useful in detecting relations, especially for small datasets.

The Pearson correlation, also called the linear correlation coefficient, is the most commonly used parametric test to determine if variables are related (Helsel and Hirsch, 1992). Data that are perfectly linear with a positive slope have a Pearson correlation of 1 and -1 if the slope is negative. A correlation of zero indicates there is no relation between the variables. The Spearman rank correlation is a non-parametric test that is similar to the Pearson correlation but is computed on the ranks of the data. The Wilcoxon sign-rank test was used to compare isotopic data from Walker Lake. A level of significance ( $\alpha$ value) of 0.05 was used in all statistical tests. The $\alpha$ value is the probability of incorrectly rejecting the null hypothesis. The $p$-value is a diagnostic statistic computed from the data that is compared to the $\alpha$ value. If the $p$-value is less than the $\alpha$ value, then there is at least a 95-percent probability of correctly rejecting the null hypothesis and accepting the alternate hypothesis.

\section{Hydrologic Setting of the Lower Walker River Basin}

\section{Walker River}

Most of the annual streamflow in the lower Walker River occurs during late spring and early summer when snow melts from high elevations in the Sierra Nevada. Spring runoff usually starts in late April or early May and lasts through July (fig. 24). Streamflow normals of gaged and ungaged tributaries to the Walker River are being calculated for this study.

Preliminary estimates indicate the sum of 1971-2000 tributary normals is about 390,000 acre-ft. This total is 63,000 acre-ft (20 percent) more than the mean estimated by Thomas (1995), who did not include runoff from the Sweetwater Range or estimate ungaged runoff. The 1971-2000 streamflow normal at the Wabuska gage is 138,000 acre-ft, so about 252,000 acre-ft (65 percent) is diverted for irrigation, transpired by riparian vegetation, evaporates from reservoirs, and recharges alluvial aquifers upstream from the gage.

Mean annual streamflow listed in table 4 indicates there is little change in flow along the Walker River downstream from the Wabuska gage. However, this is misleading because stations have been operating during different periods which affect the means. Annual streamflow occurs in cycles of wet and dry years, so many years of continuous data are needed for the period-of-record mean to represent the true mean. A good example of the period-of-record mean not representing the true mean is the Little Dam gage. This gage has been operated for few years and most of those years were above average, so the period-of-record mean is much higher than means for upstream gages.

The Wabuska gage has been operating continuously since 1945 (fig. 25). The mean for the 63-year period 1945-2007 is 130,000 acre-ft/yr and there is no trend of increasing or decreasing discharge (Pearson correlation -0.02). Forty (63 percent) of the 63 years had below average streamflow and 23 years (37 percent) had average or above average streamflow. Typically, 3-4 consecutive years with below average streamflow is followed by 1 or 2 years of average or above average streamflow. The longest period of below average streamflow was 8 years (1987-94). This was followed by 5 years (1995-99) of above average streamflow, the longest wet period on record.

From 1971 to 2000, the Wabuska gage had 19 years (63 percent) below and 11 years ( 37 percent) above the streamflow normal of 138,000 acre-ft. These percentages of above and below normal streamflow are the same as the 19452007 period of continuous record. For the entire period of record, however, the mean of 121,000 acre-ft/yr is lower than either the 63-year or 30-year means. Prior to 1945, 72 percent of the years had below average streamflow. Including the discontinuous record in the calculation biases the mean low. 


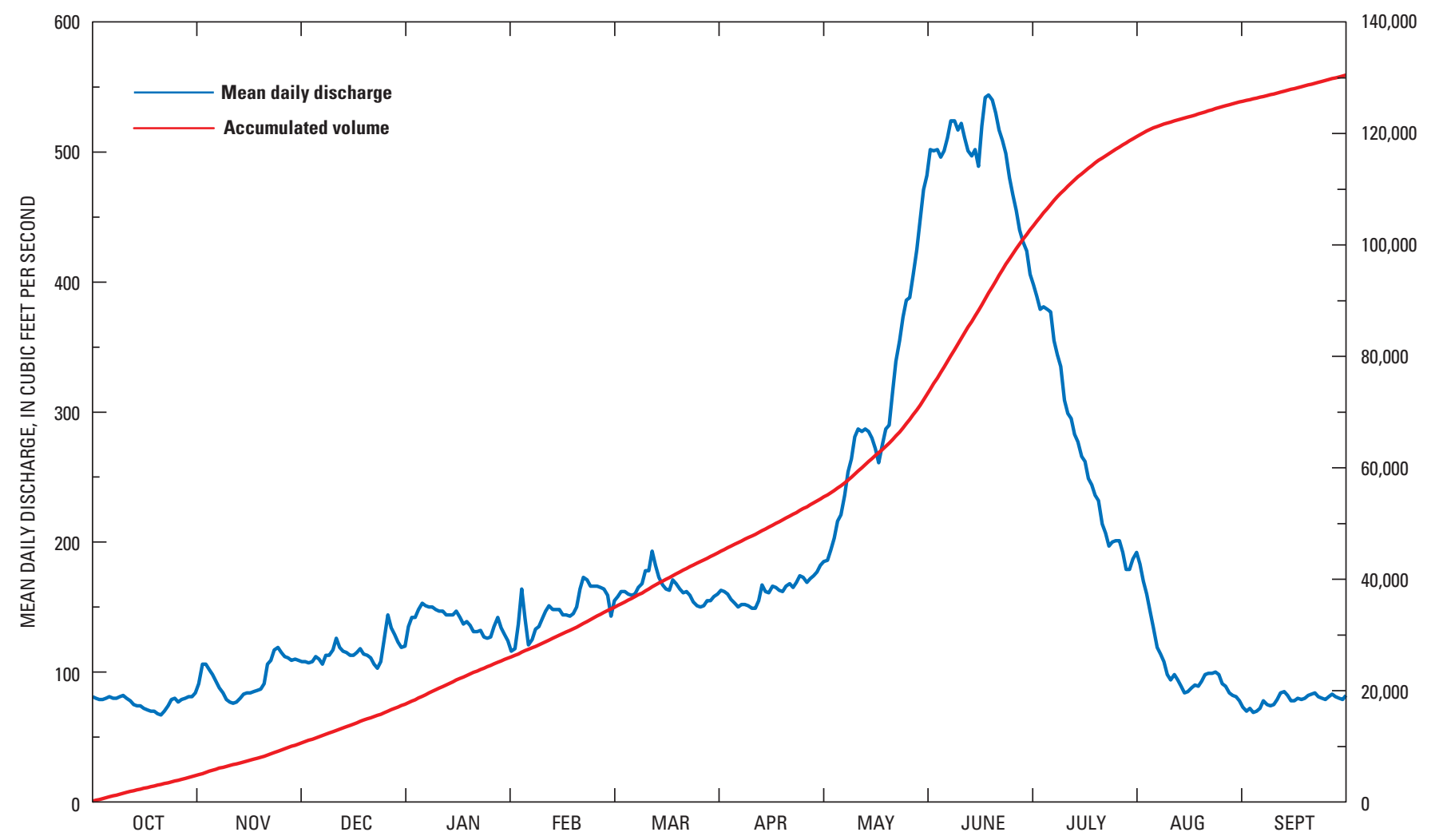

Figure 24. Mean daily discharge and accumulated volume of discharge for water years 1945 through 2007, Walker River near Wabuska, Nevada (10301500).

Table 4. Streamflow and diversion gaging stations in the lower Walker River basin, Nevada.

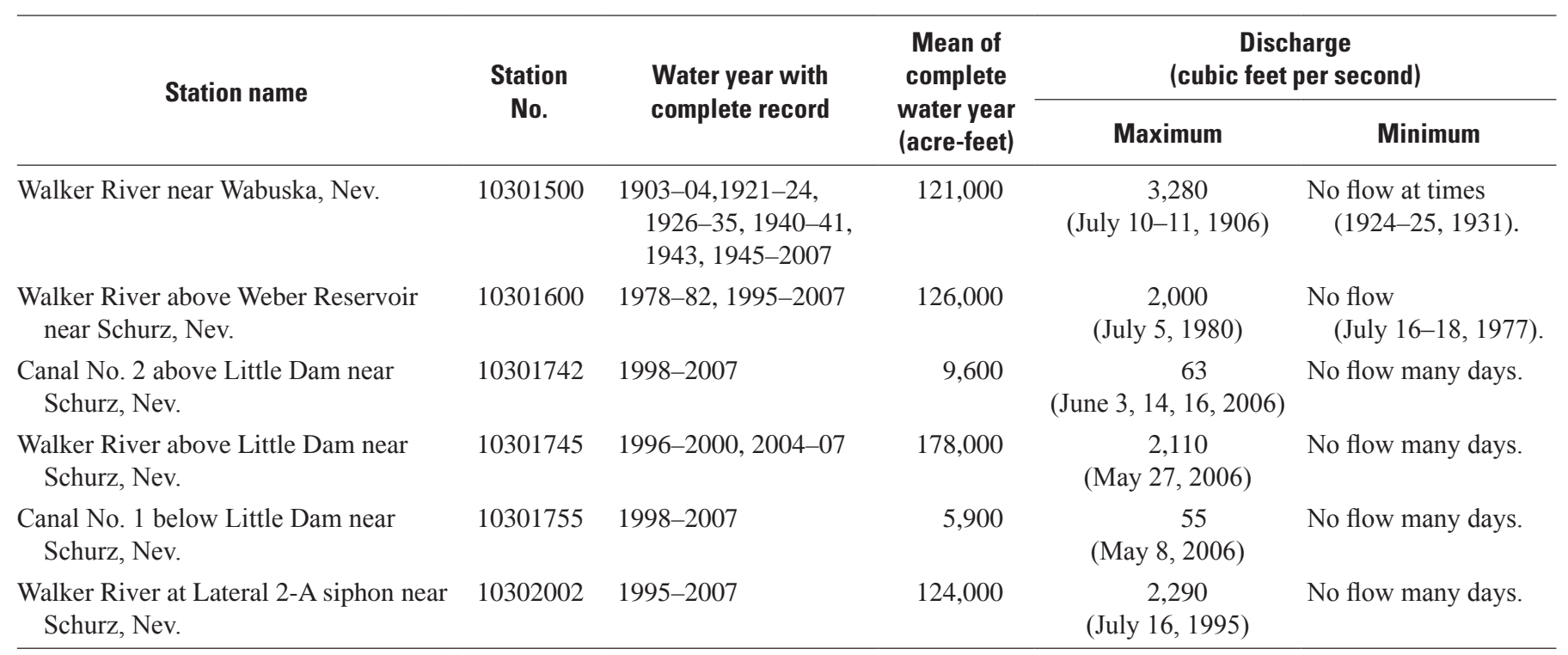




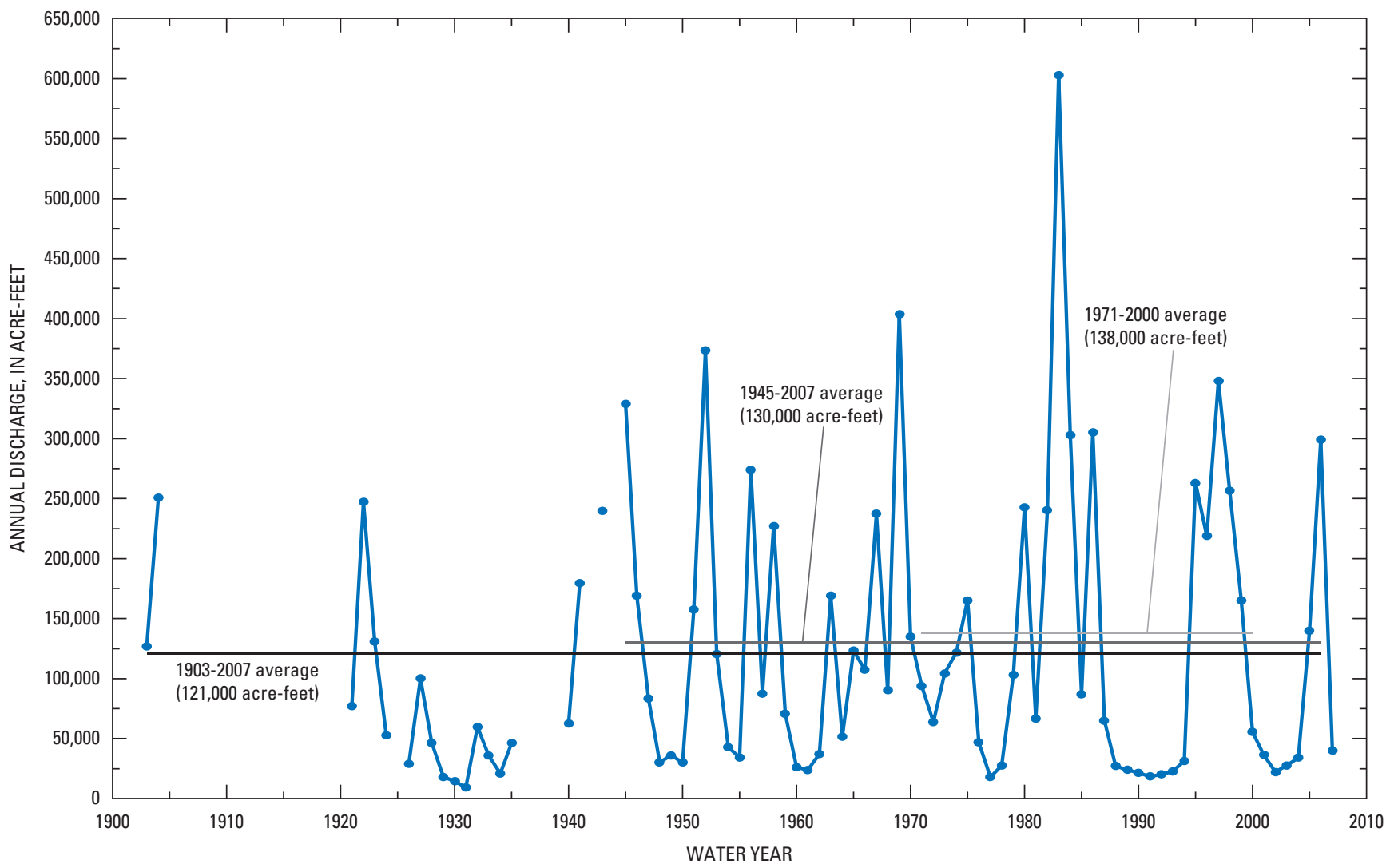

Figure 25. Annual discharge at the Walker River near Wabuska, Nevada (10301500) for water years 1903 through 2007. Broken lines indicate incomplete water years prior to 1945.

The highest discharge rate in the lower Walker River basin was 3,280 ft $3 / \mathrm{s}$ measured at the Wabuska gage in 1906, prior to construction of Topaz Lake and Bridgeport Reservoir (table 4). Since construction, discharge at the Wabuska gage has not exceeded 2,800 ft $3 / \mathrm{s}$. The highest discharge rates occurred during spring runoff, but high flows also occur during winter from rain-on-snow events such as the 1997 flood (Thomas and Hess, 1997). Peak discharge at the Wabuska gage was $2,560 \mathrm{ft}^{3} / \mathrm{s}$ on January 6,1997 , after rain melted a large portion of the snowpack. During the spring 2005 runoff, discharge as high as $1,580 \mathrm{ft}^{3} / \mathrm{s}$ at the Lateral 2-A gage damaged the bridge where Highway 95 crosses the Walker River in Schurz, Nev. The bridge was reconstructed and was not damaged by flows as high as $2,020 \mathrm{ft}^{3} / \mathrm{s}$ during the spring 2006 runoff.

The Reservation has a water right for $26.25 \mathrm{ft}^{3} / \mathrm{s}$ for 180 days during the growing season (Horton, 1995). Discharge is measured at the Wabuska gage, stored in Weber Reservoir, and used to irrigate crops on the Reservation. Flow was zero at certain times during 1924, 1925, and 1931 (table 4) and less than $2 \mathrm{ft}^{3} / \mathrm{s}$ during July 1977 . No flow was measured at the Cow Camp gage during that month.
Streamflow below Weber Dam mainly depends on releases from the reservoir (fig. 26A). The Little Dam gage typically has flow even when there are no releases from Weber Reservoir (fig. 26B). Discharge less than $3 \mathrm{ft}^{3} / \mathrm{s}$ likely is leakage from Weber Dam that evapotranspires or infiltrates before reaching the Lateral 2-A gage. The Lateral 2-A gage seldom has flow during droughts. Groundwater discharge sustains streamflow around $1 \mathrm{ft}^{3} / \mathrm{s}$ at the Powerline and near Mouth gages during autumn and winter, but streamflow often is zero during spring and summer when ET lowers groundwater levels.

\section{River Quality}

Specific conductance is an indirect measure of dissolvedsolids concentration and has been monitored at gaging stations in the upper and lower Walker River basin since 1968. Specific conductance is inversely related to stream discharge at all gages due to dilution. Inflow to Smith Valley, measured at the West Walker River at Hoye Bridge near Wellington (10297500), has a median and mean specific conductance of 180 and $210 \mu \mathrm{S} / \mathrm{cm}$, respectively (fig. 27). Outflow from Smith 


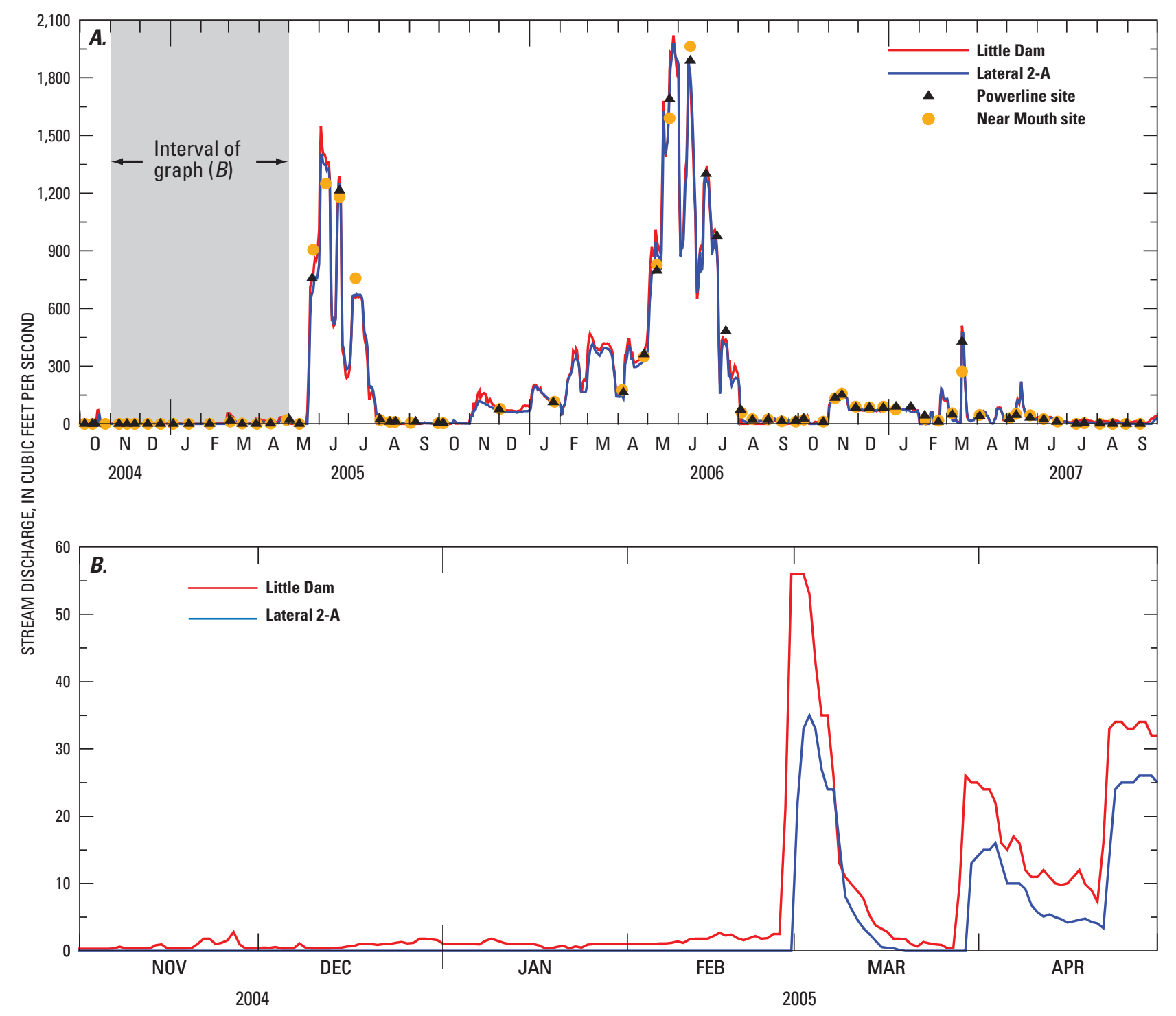

Figure 26. Daily mean discharge at the $(A)$ Walker River above Little Dam near Schurz, Nevada (10301745), Walker River at Lateral 2-A siphon near Schurz, Nevada (10302002), Walker River near Mouth at Walker Lake (10302025), October 2004 through September 2007 and (B) Little Dam and Lateral 2-A gaging stations, November 2004 through April 2005.

Valley and inflow to Mason Valley, measured at the Hudson gage, has a median and mean specific conductance of 320 and $330 \mu \mathrm{S} / \mathrm{cm}$, respectively, indicating dissolved solids increase about 60 percent through Smith Valley. Inflow to Mason Valley at the Strosnider gage has a median and mean specific conductance of $280 \mu \mathrm{S} / \mathrm{cm}$. About 55 percent of inflow to Mason Valley is from the West Fork at the Hudson gage and 45 percent is from the East Fork of the Walker River at the Strosnider gage (U.S. Geological Survey, 2007), so the flowweighted specific conductance of inflow is about $310 \mu \mathrm{S} / \mathrm{cm}$. Outflow from Mason Valley has a median and mean value of 460 and $470 \mu \mathrm{S} / \mathrm{cm}$, respectively, at the Wabuska gage, indicating dissolved solids increase another 50 percent through Mason Valley.
Specific conductance has a median and mean value of $460 \mu \mathrm{S} / \mathrm{cm}$ at the Lateral 2-A gage, indicating no change in dissolved solids between Wabuska and Schurz, Nev. The lack of change indicates evaporation is minor and a small amount of diversions return to the river along this reach. Median and mean specific conductance increases to 530 and $510 \mu \mathrm{S} / \mathrm{cm}$, respectively, at the Powerline gage and 740 and $870 \mu \mathrm{S} / \mathrm{cm}$, respectively, at the near Mouth gage due to groundwater discharge. Specific conductance of groundwater along this reach ranges from 700 to $1,000 \mu \mathrm{S} / \mathrm{cm}$, and many specific-conductance measurements were made during low flow (less than $1 \mathrm{ft}^{3} / \mathrm{s}$ ) when most streamflow was groundwater discharge. 


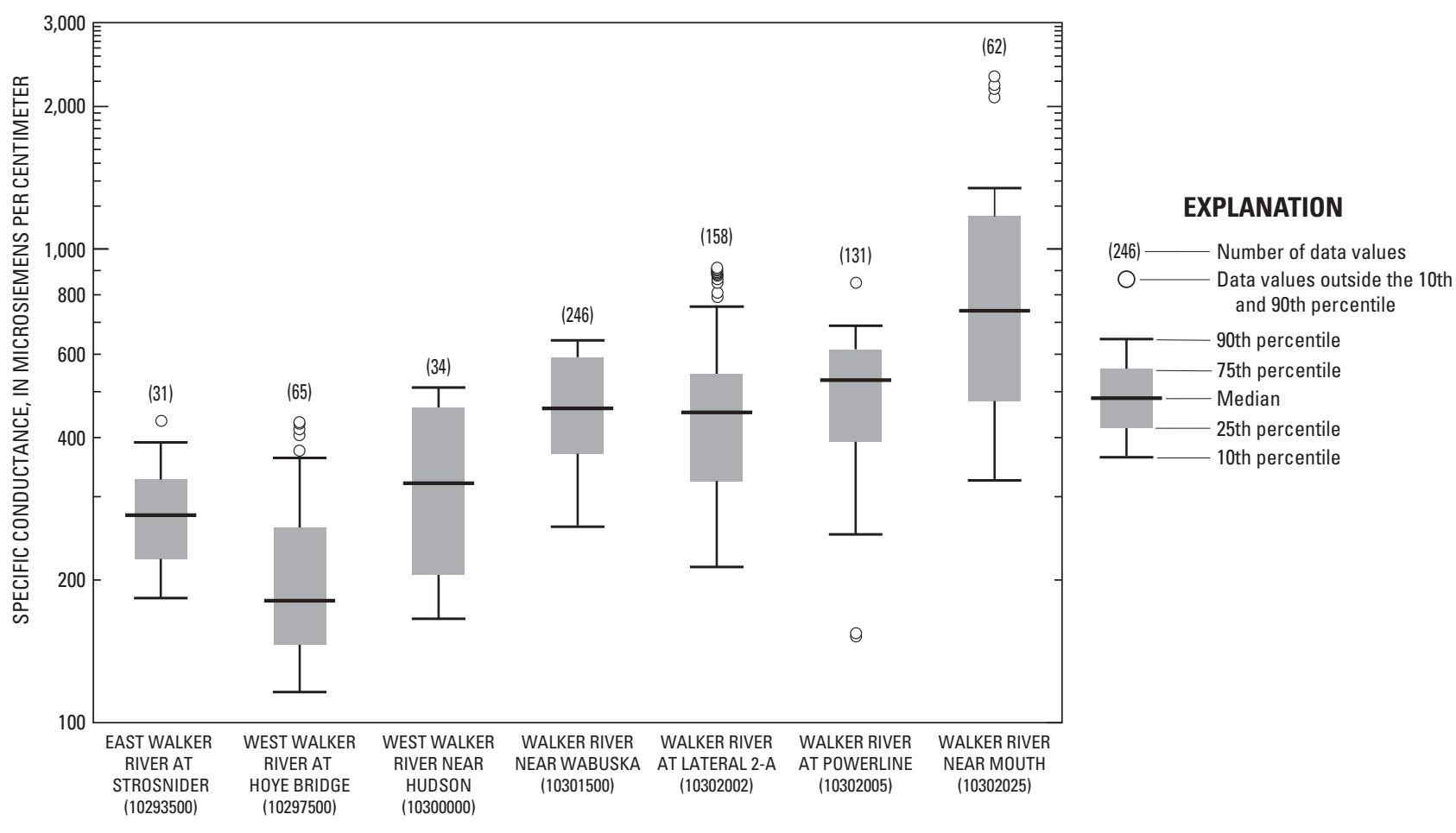

Figure 27. Ranges in specific conductance at streamflow-gaging stations in the Walker River basin, Nevada.

Dissolved-solids concentrations were measured in a subset of samples with specific-conductance measurements. Linear regression of the data was done so dissolved solids (DS), in milligrams per liter, could be estimated from specific conductance ( $\mathrm{SpC}$ ond), in microsiemens per centimeter at $25^{\circ} \mathrm{C}$. The regression equation had an adjusted $\mathrm{R}^{2}$ of 0.96 and standard error of $36 \mathrm{mg} / \mathrm{L}$ :

$$
D S=0.66 * \text { SpCond }-13 \text {. }
$$

Using mean specific-conductance values and equation 3, the mean dissolved solids in streamflow at the Wabuska and Lateral 2-A gages is about $300 \mathrm{mg} / \mathrm{L}$. Streamflow discharging into Walker Lake has a mean dissolved-solids concentration of about $560 \mathrm{mg} / \mathrm{L}$ and a maximum of 1,500 mg/L during low flows (less than $1 \mathrm{ft}^{3} / \mathrm{s}$ ). For comparison, the secondary drinking-water standard is $500 \mathrm{mg} / \mathrm{L}$ (U.S. Environmental Protection Agency, 2008a). Manganese exceeded the secondary drinking-water standard of $0.05 \mathrm{mg} / \mathrm{L}$ in the Walker River from the Cow Camp gage to Walker Lake. No other constituents that were measured exceeded primary or secondary drinking-water standards.

\section{Streams in the Wassuk and Gillis Ranges}

Spring runoff occurs at about the same time in the Wassuk Range, Sierra Nevada, and Toiyabe Range 80 mi east of Walker Lake (fig. 28). Spring runoff typically begins in late April to early May and peaks during late May to early June. Flows decline through June and early July and reach baseflow discharge in late July to early August. Except for occasional storms, discharge remains steady until spring runoff the following year.

Perennial streams that drain the Mount Grant area are diverted for municipal supply at the Army Depot. The largest perennial drainage basin is Cottonwood Creek near the town of Walker Lake. The next largest drainage basins are west and southwest of Hawthorne and include Cat Creek, Corey Creek, and Little Squaw Creek. Smaller perennial streams, such as Rose Creek, also drain the Wassuk Range. Maximum discharge at the Cottonwood Creek gage $\left(4.1 \mathrm{ft}^{3} / \mathrm{s}\right)$ and Rose Creek gage $\left(2.7 \mathrm{ft}^{3} / \mathrm{s}\right)$ were measured during May 2005 . Instantaneous discharge measured at other streams ranged from 0 to $1.22 \mathrm{ft}^{3} / \mathrm{s}$ during March through May 2004 to 2007 . During July 2006, $200 \mathrm{ft}^{3} / \mathrm{s}$ was estimated at the streamflowgaging station Reese River Canyon at Canyon Mouth near Schurz, Nev. (10302009). 


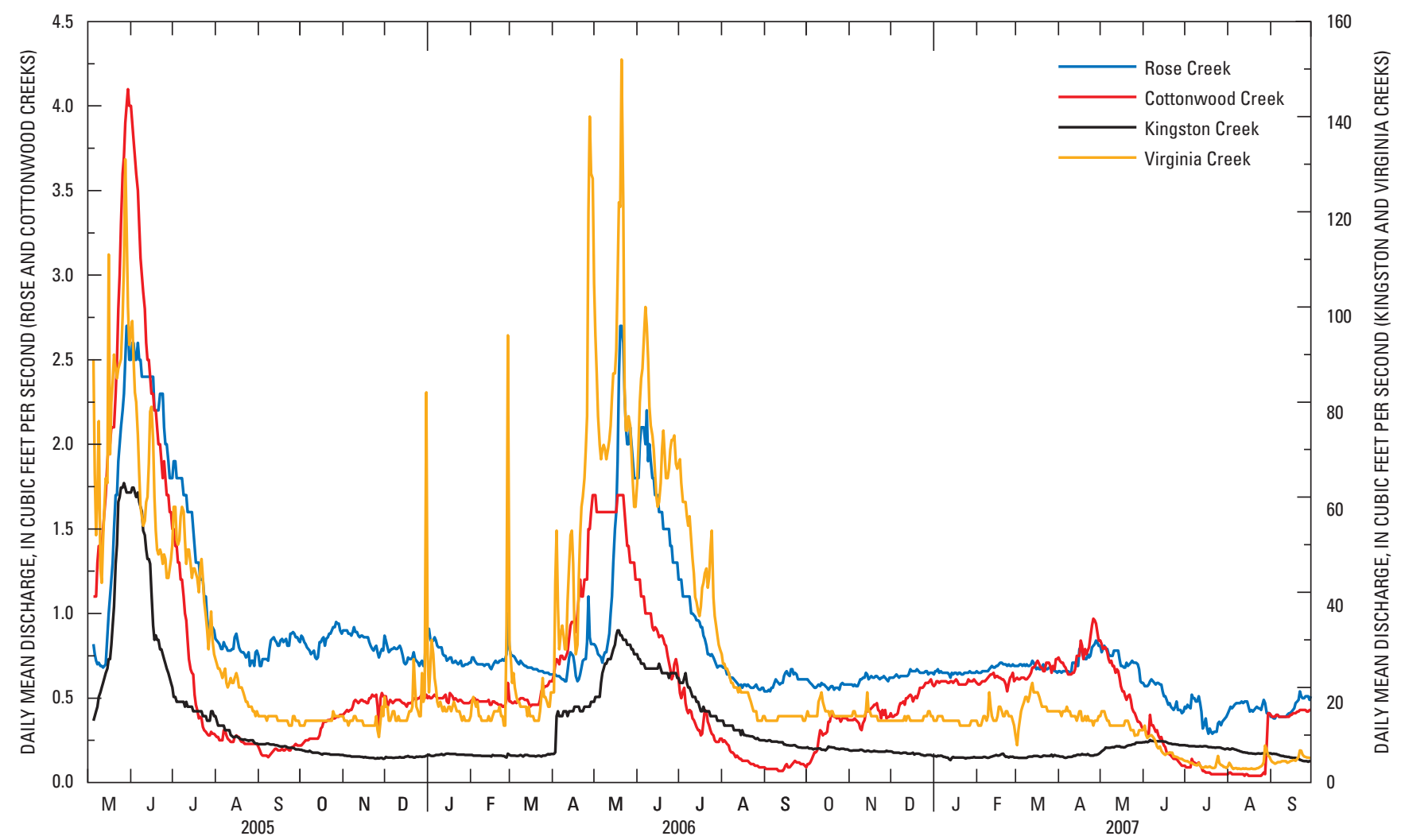

Figure 28. Daily mean discharge from drainage basins in the Sierra Nevada and Wassuk and Toiyabe Ranges, May 2005 through September 2007. Rose Creek near Walker Lake (10302145), and Cottonwood Creek near Walker Lake, Nevada (10302160), are in the Wassuk Range. Kingston Creek below Cougar Canyon near Austin, Nevada (10249280), is in the Toiyabe Range. Virginia Creek near Bridgeport, California (10289000), is in the Sierra Nevada.

All streams in the Gillis Range are intermittent. The streamflow-gaging station Wildhorse Canyon near Walker Lake (Wildhorse gage, 10302030), was installed to measure intermittent flow in the largest drainage basin in the Gillis Range. No flow was measured during 2005. About $2 \mathrm{ft}^{3} / \mathrm{s}$ was measured at the Wildhorse gage on May 20, 2006, and less than $2 \mathrm{ft}^{3} / \mathrm{s}$ was measured several times during the 2007 water year. Runoff from the Sierra Nevada was above average during 2005 and 2006 and below average during 2007.

\section{Soils}

Soils were mapped throughout Nevada to a maximum depth of $5 \mathrm{ft}$ by the Natural Resources Conservation Service and grouped by Maurer and others (2004) into five categories based on ranges in soil permeability. Soil permeability is high (10-20 ft/d) along the active channel of the lower Walker River and is very high (20-30 ft/d) surrounding the lower Walker River, Walker Lake, and along the western slopes of the Gillis Range (fig. 29). Soils along the eastern Wassuk Range mostly are moderately permeable $(5-10 \mathrm{ft} / \mathrm{d})$ with narrow bands of low permeability (1-5 ft/d) north and south of Walker Lake. Hardpan is a dense, nearly impervious stratum that commonly is formed by calcium carbonate cementing soil particles. Hardpan was found in highly permeable soils in the Whisky Flat area south of Hawthorne, Nev.
Areas of low soil permeability comprise a small percentage of the lower Walker River basin and mostly occur along the northern Wassuk Range, the Calico Hills northeast of Schurz, Nev., high elevations of the Gillis Range, and the Excelsior Mountains east of Whisky Flat. The predominance of moderately to very highly permeable soils in the lower Walker River basin would favor infiltration versus runoff. The Gillis Range, Excelsior Mountains, and Anchorite Hills would be sources of direct runoff to Walker Lake only during extreme precipitation events.

\section{Hydrogeologic Units}

Hydrogeologic units in Nevada were mapped and described by Maurer and others (2004). Hydrogeologic units were divided into two main categories: consolidated rocks and unconsolidated sediments. Consolidated rocks form the mountains that separate basins where unconsolidated sediments are deposited. Consolidated rocks consist of eight hydrogeologic units and unconsolidated sediments consist of four hydrogeologic units. The lower Walker River basin has four of the eight consolidated rock hydrogeologic units and all four unconsolidated sediment hydrogeologic (ig. 30). 


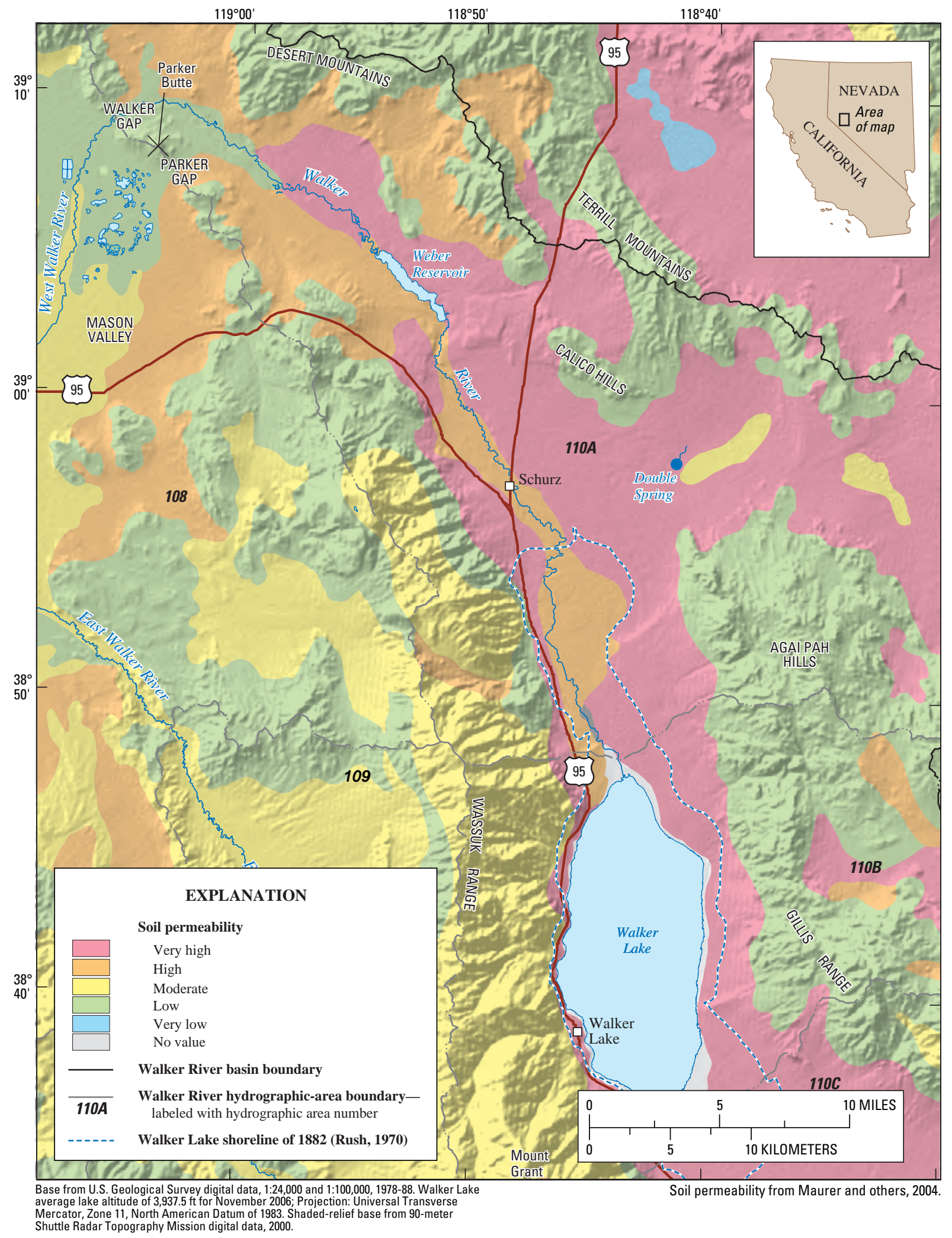

Figure 29. Distribution of soil permeability in the lower Walker River basin, Nevada. 


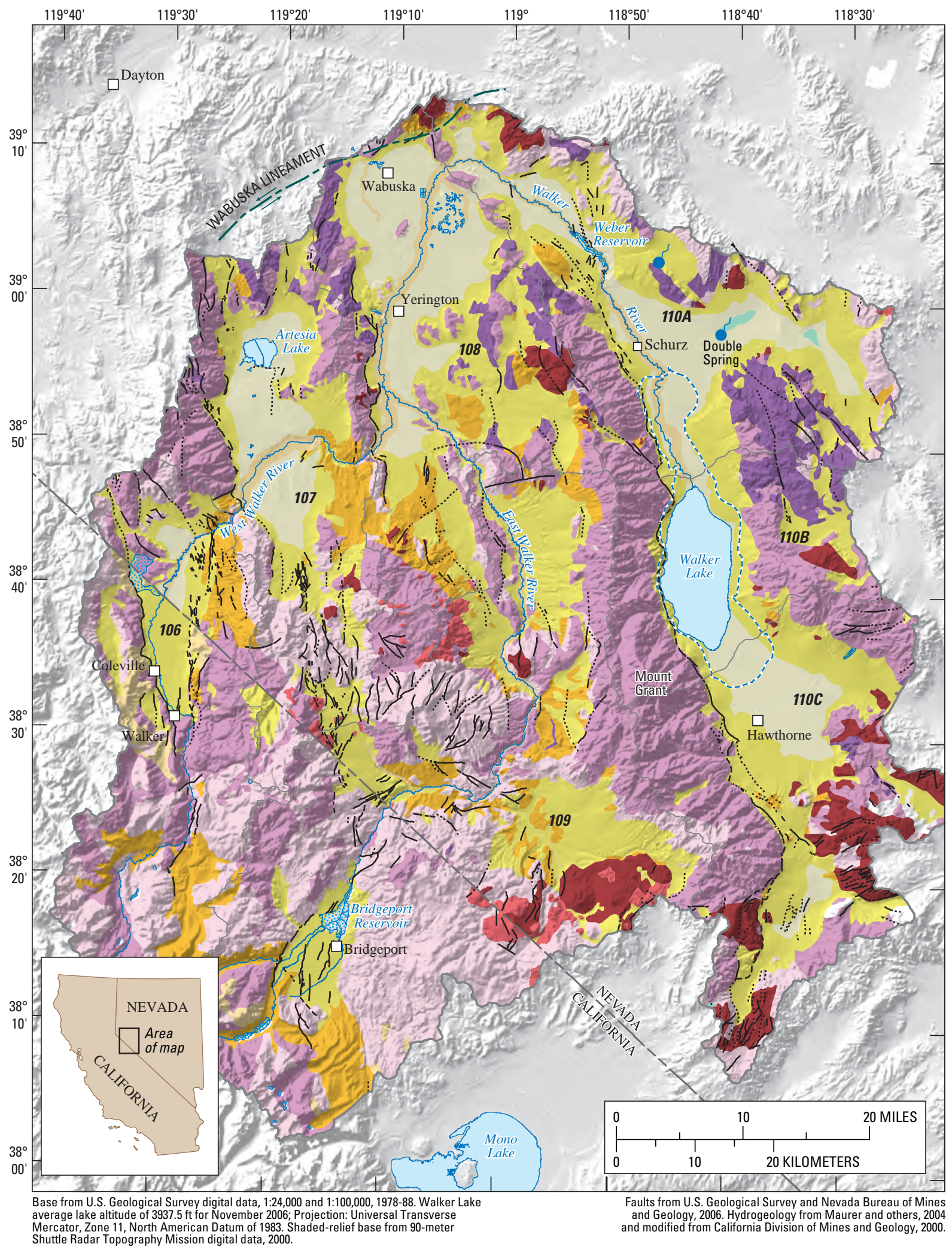

Figure 30. Distribution of hydrogeologic units in the Walker River basin, Nevada and California. 


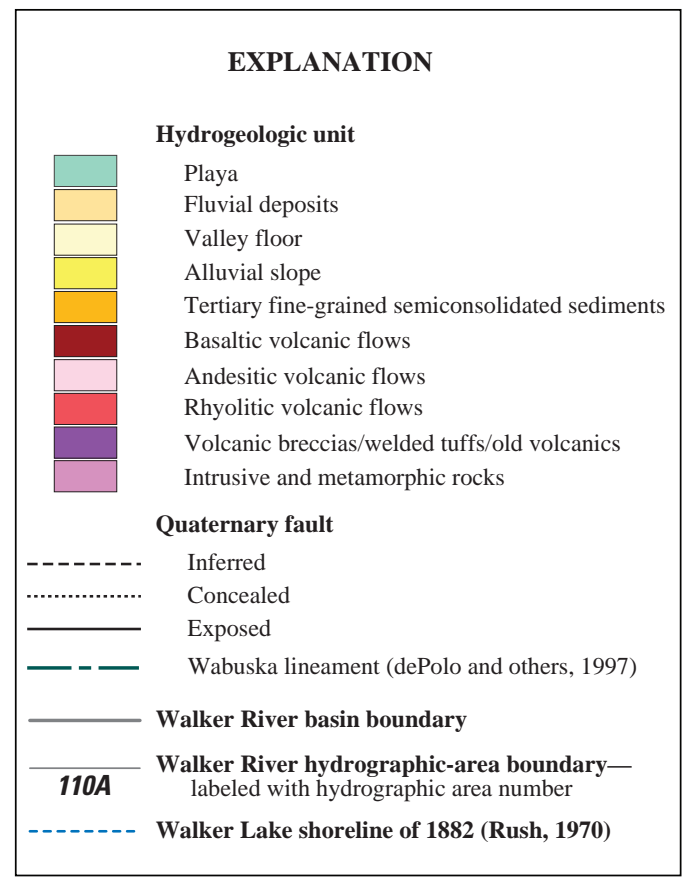

Almost all of the Wassuk Range and the southern half of the Gillis Range are comprised of intrusive and metamorphic rocks (Maurer and others, 2004). The northern one-half of the Gillis Range, parts of the Calico Hills, and the northern end of the Wassuk Range are comprised of volcanic breccias, welded tuffs, and volcanic rocks older than Tertiary age. Andesitic and basaltic volcanic flows comprise most of the Excelsior and Desert Mountains, Anchorite Hills, parts of the Calico Hills, and Parker Butte south of the Wabuska gage.

Except for basaltic flows, the hydraulic conductivity of consolidated-rock hydrogeologic units is low (Maurer and others, 2004). Two domestic wells and one irrigation well were screened in fractured basalt adjacent to the Walker River in Walker Gap north of Parker Butte. Drillers' logs indicated the domestic wells produced 30-60 gal/min for 2 hours, but drawdown was not reported. These pumpage rates likely were due to fractured basalt and a hydraulic connection between the basalt and the Walker River.

The Gillis well (384709118270401) is a stock well at $5,195 \mathrm{ft}$ in the Gillis Range that is more representative of consolidated-rock aquifers. According to the driller's log, the $310-\mathrm{ft}$ well first penetrated $165 \mathrm{ft}$ of gravel, then $115 \mathrm{ft}$ of red basalt, and $30 \mathrm{ft}$ of water-bearing granite. The bottom $15 \mathrm{ft}$ of the well is screened and the static water level was $270 \mathrm{ft}$ below land surface in 1990. An aquifer test was not done, but in 2005 the pump was restricted to $5 \mathrm{gal} / \mathrm{min}$ because of excessive drawdown. Fracturing can increase the hydraulic properties of consolidated rocks, but hydrogeologic units surrounding Walker Lake likely transmit little water.
Unconsolidated sediment hydrogeologic units include fluvial deposits, valley floors, alluvial slopes, and playas. River meandering has resulted in fluvial deposits within several miles of the active channel of the lower Walker River, such as the deposits that overlie lake clays about $1 \mathrm{mi}$ north of Schurz, Nev. (fig. 31). Lithologic logs from monitoring wells installed for this study indicate that the upper $50 \mathrm{ft}$ of fluvial deposits along the Walker River are comprised of about 80 percent fine to coarse sand and gravel interbedded with sandy, silty clay. Coarse-grained strata average $8 \mathrm{ft}$ thick and clay strata average $4 \mathrm{ft}$ thick.

Valley floors are unconsolidated sediments with a slope of less than 3 percent, except for fluvial deposits and playas (Maurer and others, 2004). Valley floors in the lower Walker River basin occur along the Walker River, in the Double Spring area east of Schurz, Nev., and southeast of Walker Lake.

Lithologic logs of irrigation, supply, and stock wells that range from 240 to $520 \mathrm{ft}$ below land surface in the Schurz area indicate that the valley floor is equal amounts of clay and coarse sediments (sand and gravel). Strata of both clay and coarse sediments have an average thickness of about $20 \mathrm{ft}$. Coarse sediments likely were deposited by the Walker River. The Walker River has meandered across the valley floor for thousands of years in response to tectonic uplift of the surrounding mountains and varying sedimentation rates on the valley floor. The meandering would cause deposition of discontinuous strata of sand and gravel across much of the valley floor.

Well logs describe blue, black, green, brown, and yellow clay. Blue, black, and green clays indicate an organic rich, reducing environment and brown and yellow clays indicate an oxidizing environment. Thick strata of clay likely were deposited in Lake Lahontan. Lake clays were not mapped as a separate hydrogeologic unit by Maurer and others (2004), but are exposed on the valley floor between Wabuska and Weber Reservoir (fig. 11), along road cuts (fig. 31), and were present in most wells in the valley floor. Lake clays likely are horizontally continuous throughout the valley floor in the Schurz area, except where strata have been eroded by the Walker River. Clay strata reduce vertical groundwater flow in the valley floor and likely are the confining stratum at the Double Spring flowing well.

Lithologic logs of supply and monitoring wells that range in depth from 78 to $452 \mathrm{ft}$ indicate that the valley floor in the Hawthorne area is about 70 percent coarse sediments and 30 percent clay. Coarse strata average about $50 \mathrm{ft}$ thick and clay strata average $30 \mathrm{ft}$ thick. The exception is along the topographic low up to 4 mi southeast from the southern end of Walker Lake. Wells 500-ft and 542-ft deep have about 85 percent clay with individual clay strata up to $286 \mathrm{ft}$ thick. During highstands, alluvial slopes of the southern Gillis Range and northern Excelsior Mountains confined Lake Lahontan to a small area in the Hawthorne area, which resulted in clay strata having a relatively lower horizontal extent. 


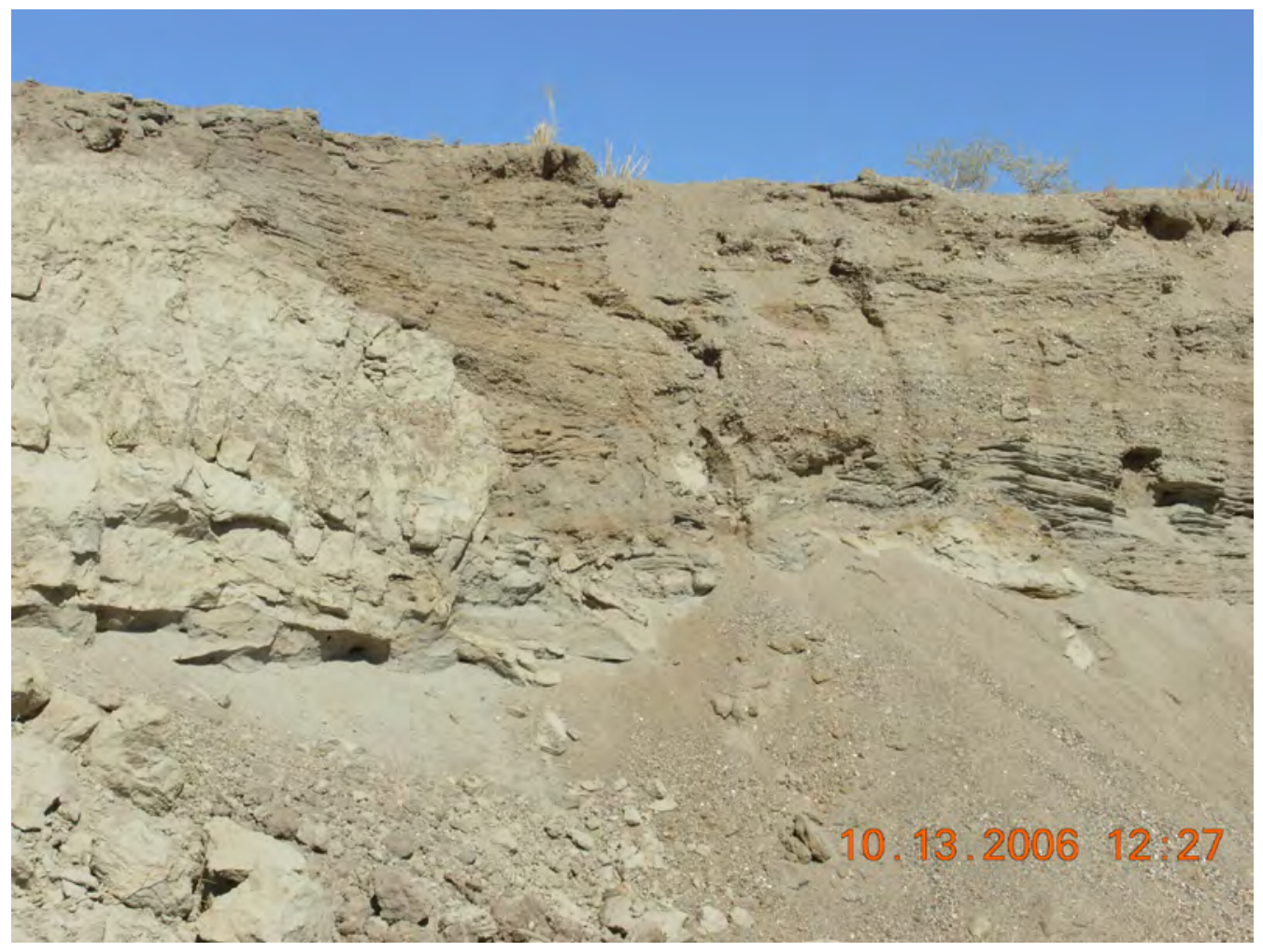

Figure 31. Lake clays overlain by fluvial sand and gravel in a road cut along Highway 95 about 1 mile north of Schurz, Nevada. (Photograph taken by Thomas J. Lopes, October 13, 2006.)

Alluvial slopes are unconsolidated sediments with a slope greater than 3 percent that are deposited along the flanks of mountain ranges (Maurer and others, 2004; fig. 32). In the lower Walker River basin, alluvial slopes extend from the eastern flank of the Wassuk Range to fluvial deposits along the Walker River and from the Wassuk and Gillis Ranges into the western and eastern sides of Walker Lake. Alluvial slopes are characterized by poorly sorted, coarse sediments with little stratification and a high vertical hydraulic conductivity (Maurer and others, 2004). Pelican Point north of Walker Lake is at the end of a large alluvial fan that was reworked into beach deposits during high lake stands (fig. 33). Lithologic logs of wells in alluvial slopes mostly describe sand, gravel, and boulders with strata of gravelly yellow clay up to $44 \mathrm{ft}$ thick at the toe of some alluvial fans.

The only playa in the lower Walker River basin is at Double Spring, 6 mi east of Schurz, Nev. The playa is a flat surface of clay with a thin salt crust and salt grass growing near the spring and the Double Spring well on the west side of the playa (fig. 34). Runoff from the northern Agai Pah Hills and southern Terrill Mountains flows into the playa and evaporates.
According to the driller's report, the 102-ft Double Spring well was drilled through two primary aquifers confined by thick strata of clay and hardpan. The first aquifer is a $16 \mathrm{ft}$ thick stratum of gravel at a depth of $17 \mathrm{ft}$ that is overlain by clay. The water quality was described as "bad" and the well was not screened in this interval. The second aquifer is a $26 \mathrm{ft}$ thick stratum of gravel starting at $76 \mathrm{ft}$ below land surface that is overlain by $24 \mathrm{ft}$ of hardpan and $19 \mathrm{ft}$ of clay.

On January 23, 2007, the Double Spring well was sounded at about $47 \mathrm{ft}$. A down-hole camera showed sand and gravel at the bottom of the well with upwelling coarse sand being stirred by the artesian flow. Samples of the sand were well rounded and coarse (approximately 0.04 in.), similar to beach sands. The hardpan and clay apparently stayed open and the bottom $55 \mathrm{ft}$ of the hole filled in with sand and gravel from the second aquifer. Everett and Rush (1967) reported the discharge was $2 \mathrm{gal} / \mathrm{min}$ on February 17, 1966. Schaefer (1980) measured $16 \mathrm{gal} / \mathrm{min}$ on February 2, 1978. During this study, $43 \mathrm{gal} / \mathrm{min}$ was measured on December 12, 2006, and $39 \mathrm{gal} / \mathrm{min}$ was measured on April 28, 2008. The increase in discharge could be due to rust and bullet holes in the piping and a split in the well casing that lowered the discharge point. 


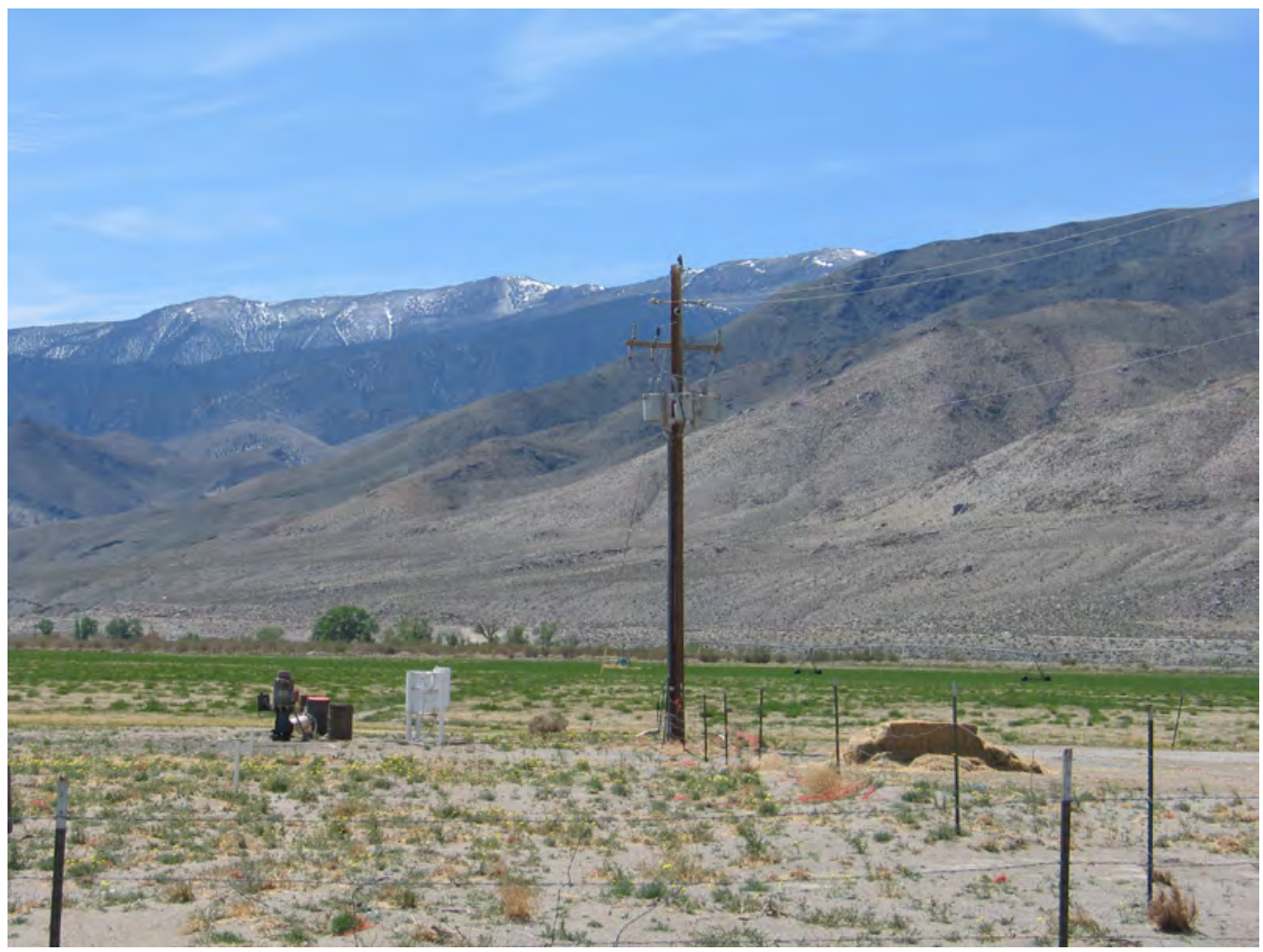

Figure 32. Alluvial fans along the eastern flank of the Wassuk Range about 4 miles south of Schurz, Nevada. The valley floor in the foreground is an alfalfa field irrigated by a well and center pivot. (Photograph taken by Thomas J. Lopes, April 23, 2004.)

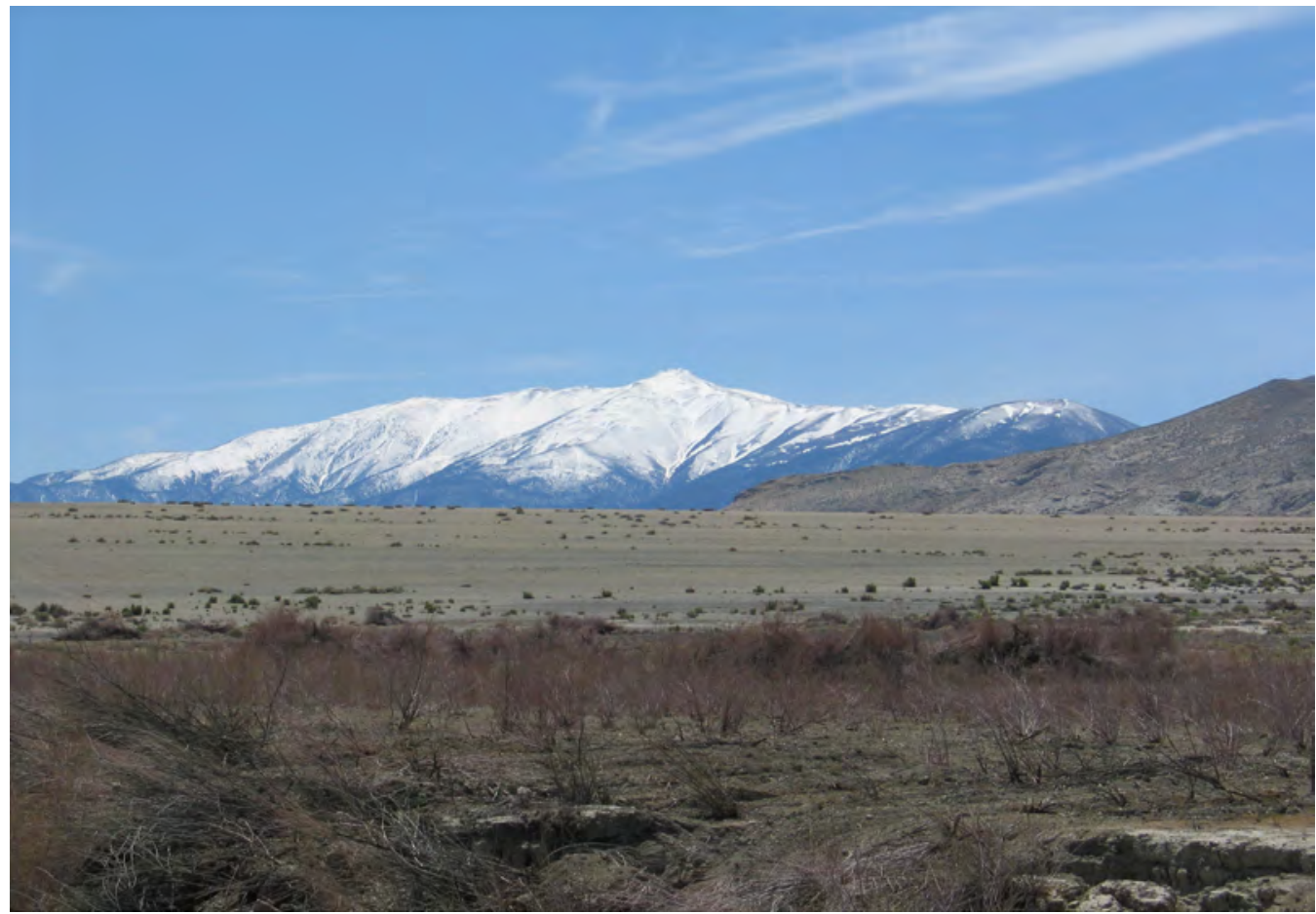

Figure 33. View looking southwest towards Mount Grant and an alluvial fan about 2 miles north of Walker Lake, Nevada, that has been reworked into beach deposits. (Photograph taken by Thomas J. Lopes, April 23, 2004.) 


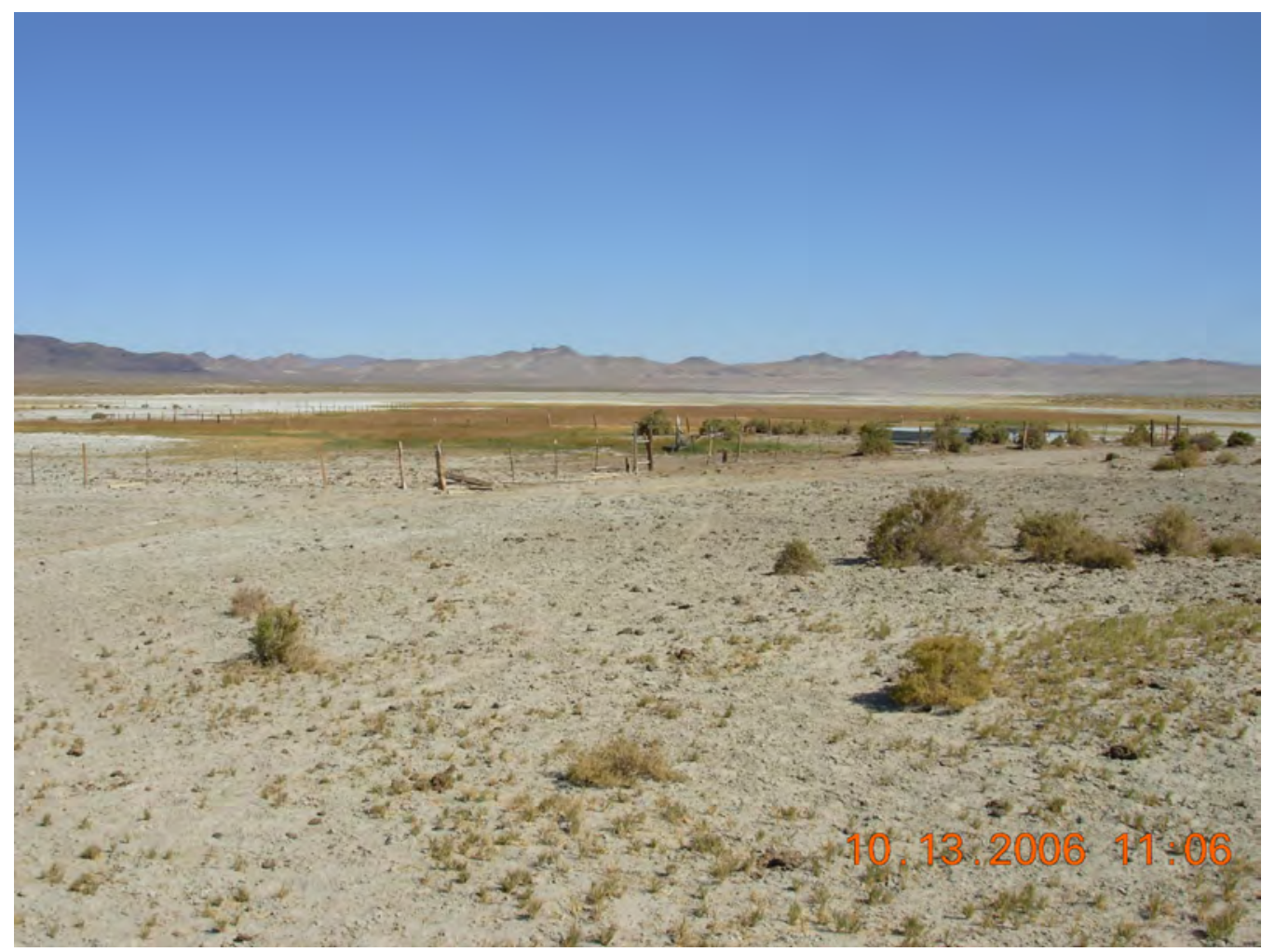

Figure 34. View looking east towards the Double Spring well (center) and playa, Walker River basin, Nevada. (Photograph taken by Thomas J. Lopes, October 13, 2006.)

Link and others (1985) described the sedimentology of Walker Lake and indicate in a schematic cross section that lake clays interfinger with alluvial-fan deposits along the lake margins. Bathymetric contours of Walker Lake indicate that alluvial fans prograded into Walker Lake up to $0.5 \mathrm{mi}$ from the 2005 shoreline (Lopes and Smith, 2007). Evidence of submerged alluvial-fan deposits include from 1 to 2 -ft boulders in $30 \mathrm{ft}$ of water near the town of Walker Lake that were observed with a submersible camera. Deltaic sediments created a 6.5 -ft tall, 1-mi wide mound that extends almost $3 \mathrm{mi}$ south from the mouth of the Walker River (Lopes and Smith, 2007).

Alluvial, fluvial, and deltaic sediments from the Wassuk and Gillis Ranges and the Walker River likely were deposited for some distance onto the lakebed when Walker Lake was a shallow or desiccated playa during much of the Holocene (Benson and Thompson, 1987; Benson and others, 1991; Benson and others, 2002). These sediments form a multilayered, confined-aquifer system that could extend several miles from the eastern, western, and northern shorelines.

\section{Alluvial Depth and Thickness}

Depth to bedrock near Double Spring ranged from about 900 to $1,600 \mathrm{ft}$ using seismic refraction (fig. 35). Schaefer (1980) estimated similar alluvial depth and thickness near Double Spring using seismic reflection. Seismic refraction detected bedrock only at lines 3 and 4 near Double Spring and neither line south of Walker Lake (fig. 23). Where bedrock was not detected, depth to bedrock was estimated by assuming the last arrivals from the farthest shots refracted from bedrock and represent minimum values.

Unsaturated alluvium was detected at all seismic lines and is from about 30 to $100 \mathrm{ft}$ thick near Double Spring. Saturated alluvium also was detected at all seismic lines and is $470 \mathrm{ft}$ to a maximum of 1,600 ft thick near Double Spring. Semiconsolidated alluvium near Double Spring was detected at all seismic lines except line 4 and is from about 320 to $350 \mathrm{ft}$ thick. Semiconsolidated alluvium may not be thick enough to detect at line 4 , which would result in over estimating the thickness of saturated alluvium.

Depth to bedrock south of Walker Lake is at least $1,500 \mathrm{ft}$ at line 1 and could not be estimated at line 2 (fig. 36A, $\underline{\text { B }}$ ). 

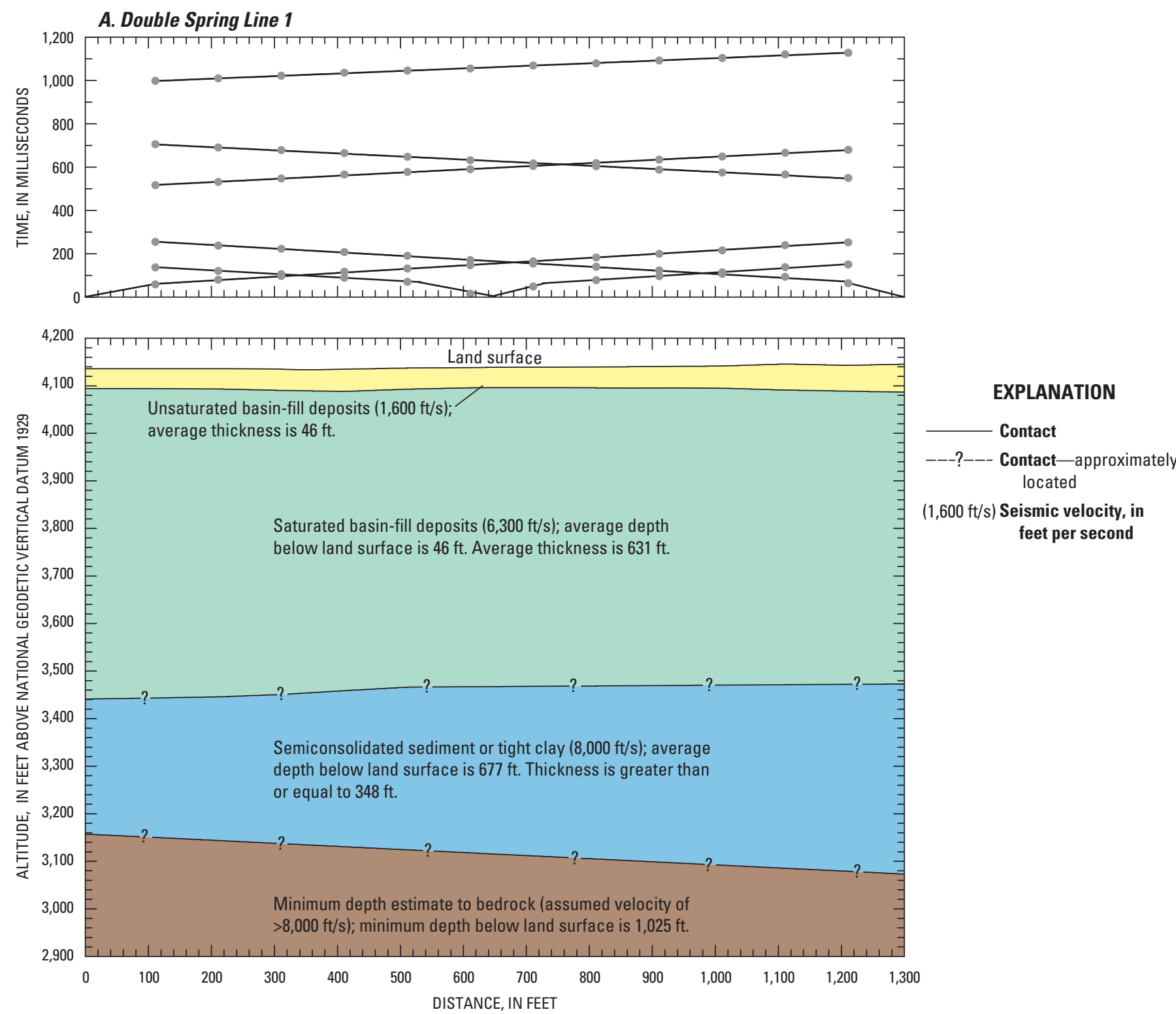

Figure 35. Depth to bedrock and thickness of alluvial strata along seismic-refraction lines $(A)$ Double Spring Line 1, $(B)$ Double Spring Line 3, and $(C)$ Double Spring Line 4, Walker River basin, Nevada. 

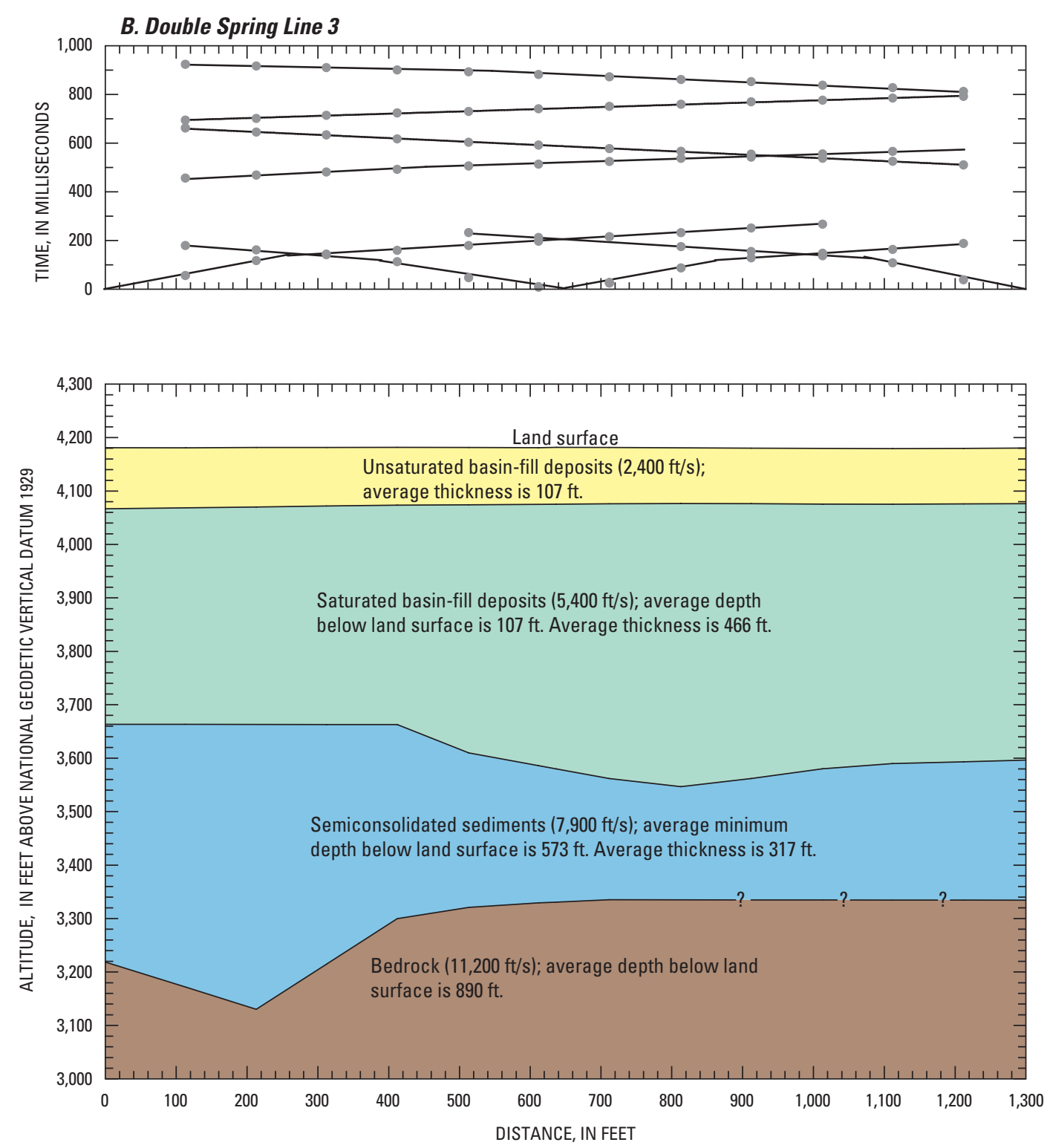

EXPLANATION

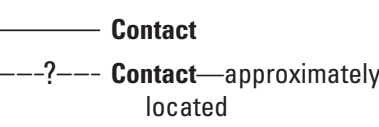

$(2,400 \mathrm{ft} / \mathrm{s})$ Seismic velocity, in feet per second

Figure 35.-Continued. 


\section{Double Spring Line 4}
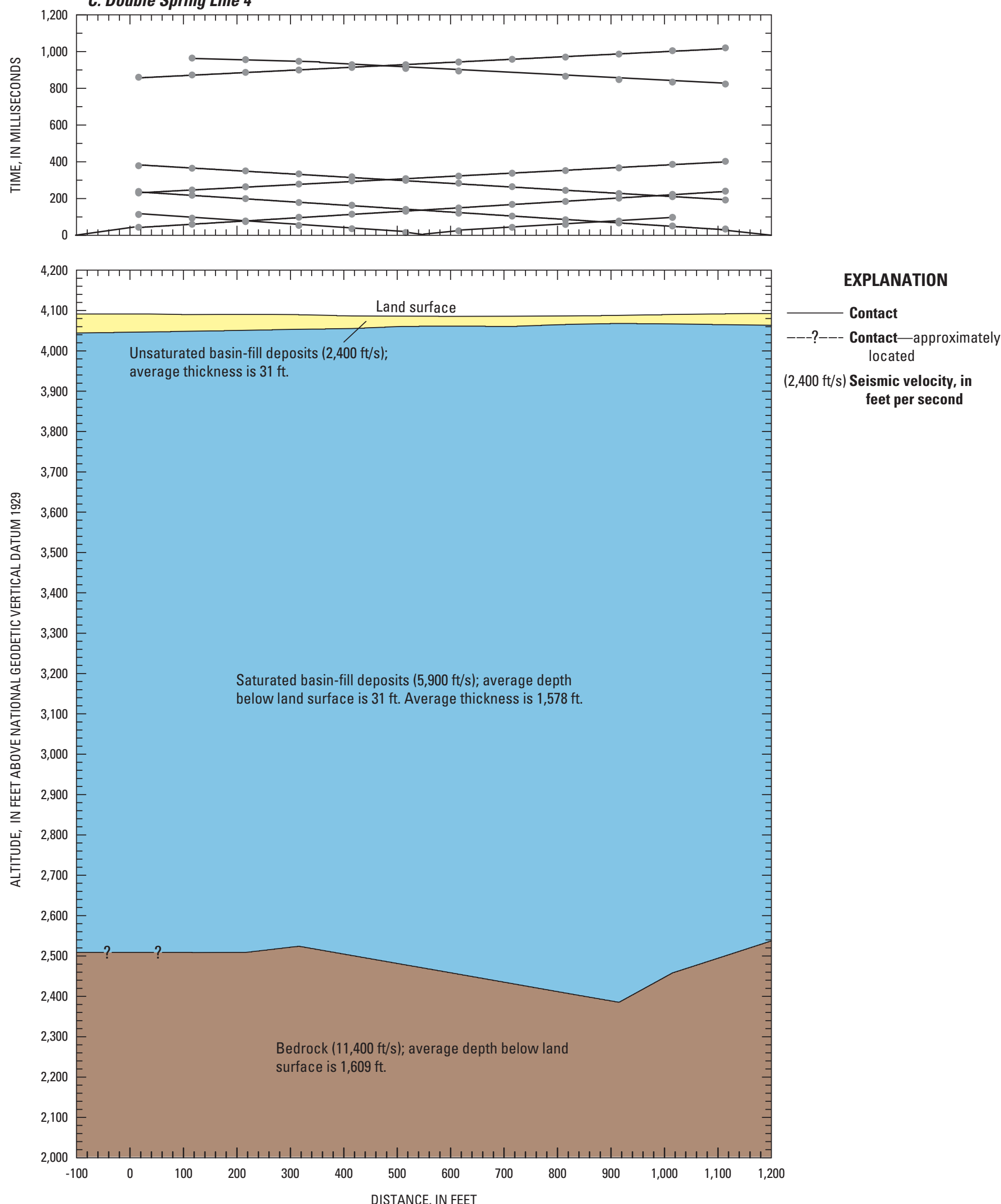

Figure 35.-Continued. 

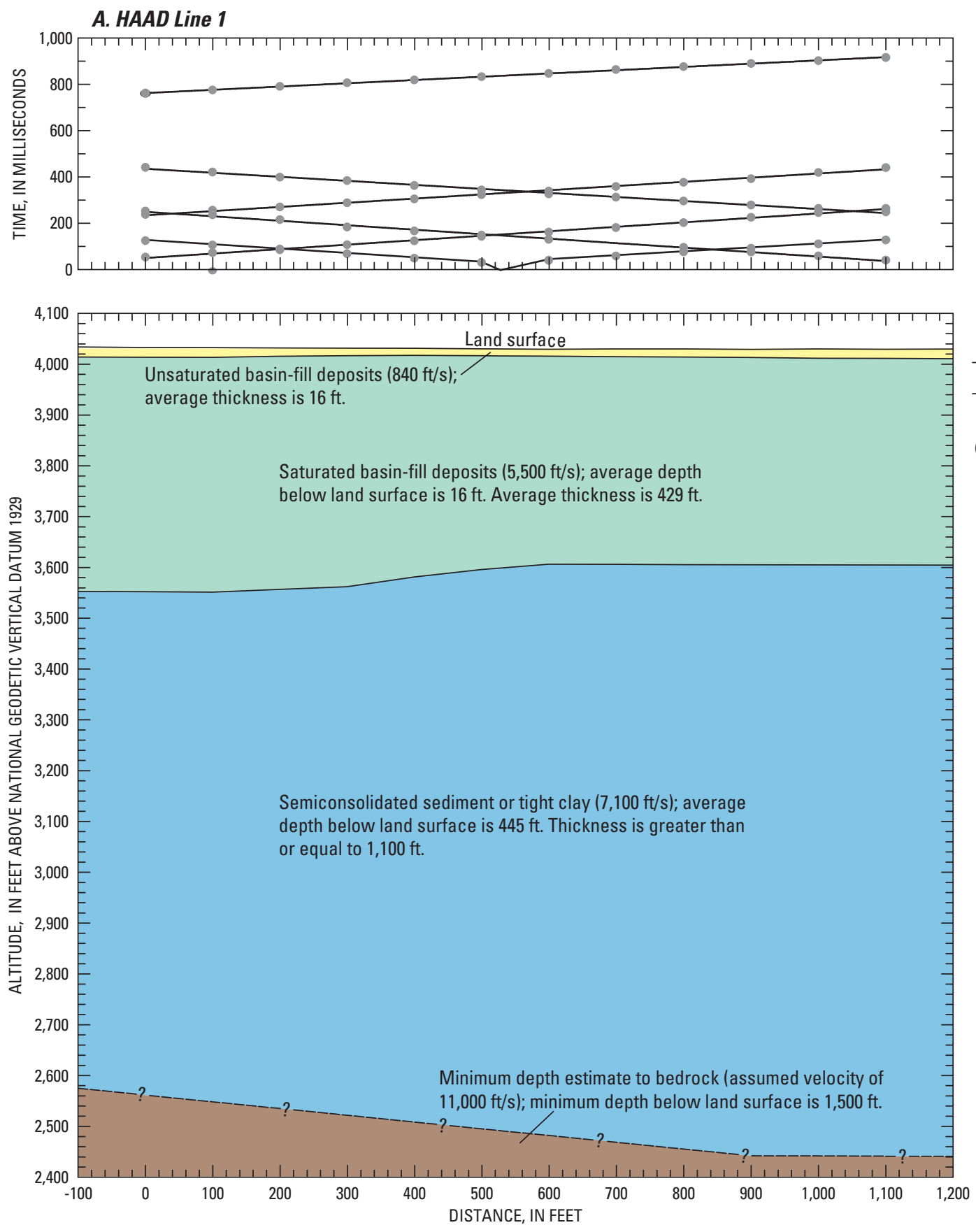

\footnotetext{
EXPLANATION

Contact

---?--- Contact-approximately located

$(840 \mathrm{ft} / \mathrm{s})$ Seismic velocity, in feet per second
}

Figure 36. Depth to bedrock and thickness of alluvial strata along seismic-refraction lines $(A)$ Line 1 and $(B)$ Line 2 on the Hawthorne Army Ammunition Depot (HAAD), Nevada. 


\section{B. HAAD Line 2}
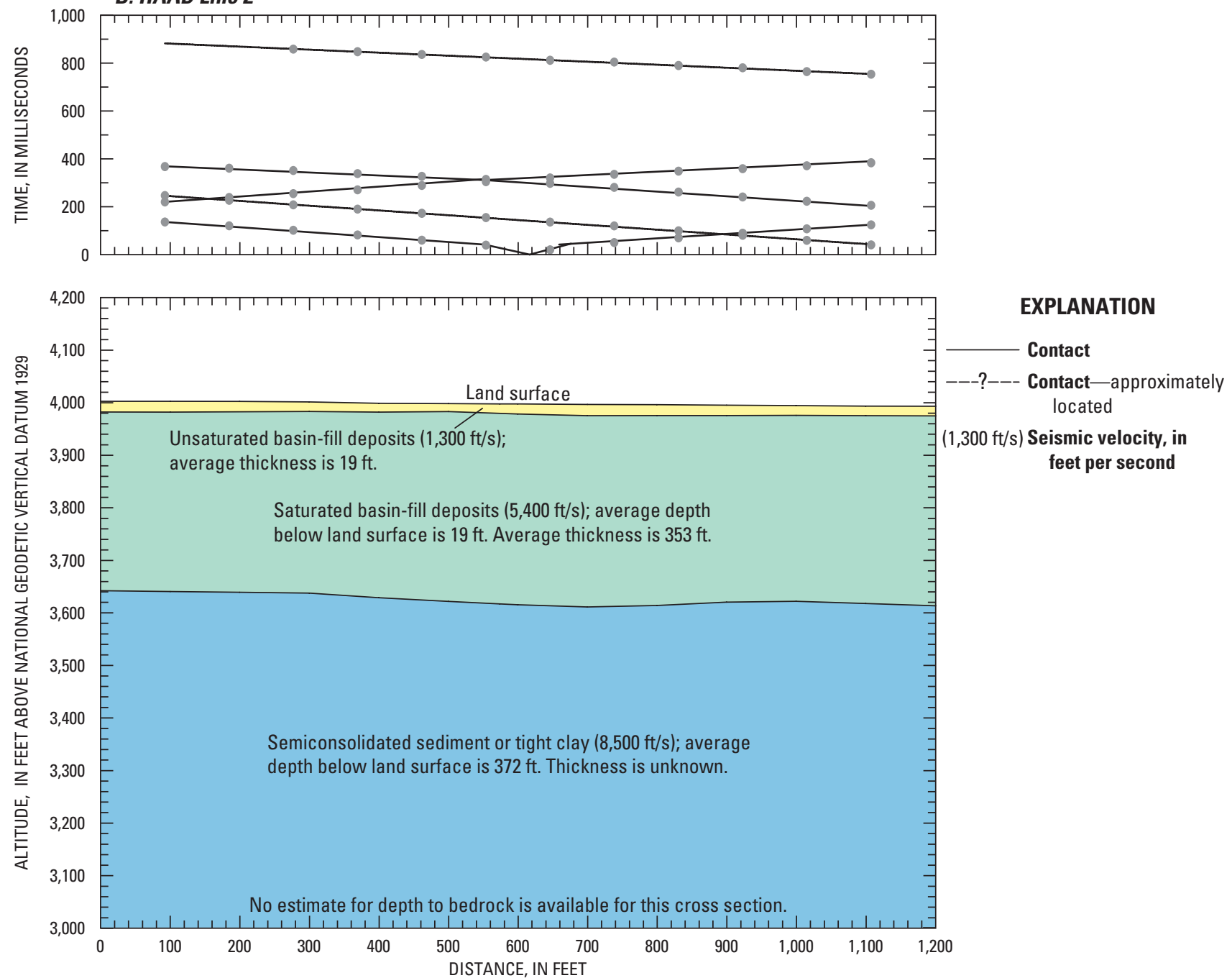

Figure 36.-Continued. 
Unsaturated alluvium is about $20 \mathrm{ft}$ thick, saturated alluvium is from 350 to $430 \mathrm{ft}$ thick, and semi-consolidated alluvium is from 370 to $1,100 \mathrm{ft}$ thick.

Blair and McPherson (1994) indicated that alluvium north of Walker Lake is an asymmetric wedge with a maximum thickness of 2,000 ft near the Wassuk Range that gradually thins toward the Gillis Range. Thicknesses of unsaturated, saturated, and semiconsolidated alluvium were not estimated. Presumably, a geophysical method such as seismic refraction was used to measure sediment thickness but the method was not described by Blair and McPherson (1994). However, the thickness and geometry seem reasonable considering results of geophysics from this study and Schaefer (1980).

Semiconsolidated alluvium was assumed to have a hydraulic conductivity at least an order of magnitude less than saturated alluvium and does not readily transmit groundwater. Generalized cross sections of the saturated alluvium that most groundwater flows through were developed for the Double Spring area and areas north and south of Walker Lake. Cross sections for the Double Spring area and the area south of Walker Lake were based on depths and thicknesses of alluvium estimated from seismic-refraction data. The cross section north of Walker Lake was modified from Blair and McPherson (1994). Seismic refraction detected the water table in the Double Spring area and south of Walker Lake. The water table north of Walker Lake was assumed to be the same altitude as the Walker River.

Alluvium in the Double Spring area is about 5.2 mi wide between the Calico and Agai Pah Hills (fig. 37). Unsaturated alluvium ranges from about $30 \mathrm{ft}$ thick at the center of the area to about $150 \mathrm{ft}$ thick near bedrock outcrops. Saturated alluvium was interpreted to be a symmetric wedge that is zero feet thick near the bedrockalluvium contact, about 1,600 ft thick near the center of the area, and has a cross-sectional area of about 460 acres.

Alluvium is about $7 \mathrm{mi}$ wide between the Wassuk and Gillis Ranges south of Walker Lake (fig. 38). Unsaturated alluvium ranges from about $15 \mathrm{ft}$ thick near the center of the area to about $80 \mathrm{ft}$ thick at the toe of alluvial fans. Saturated alluvium was interpreted to be a trapezoidal shape that is zero

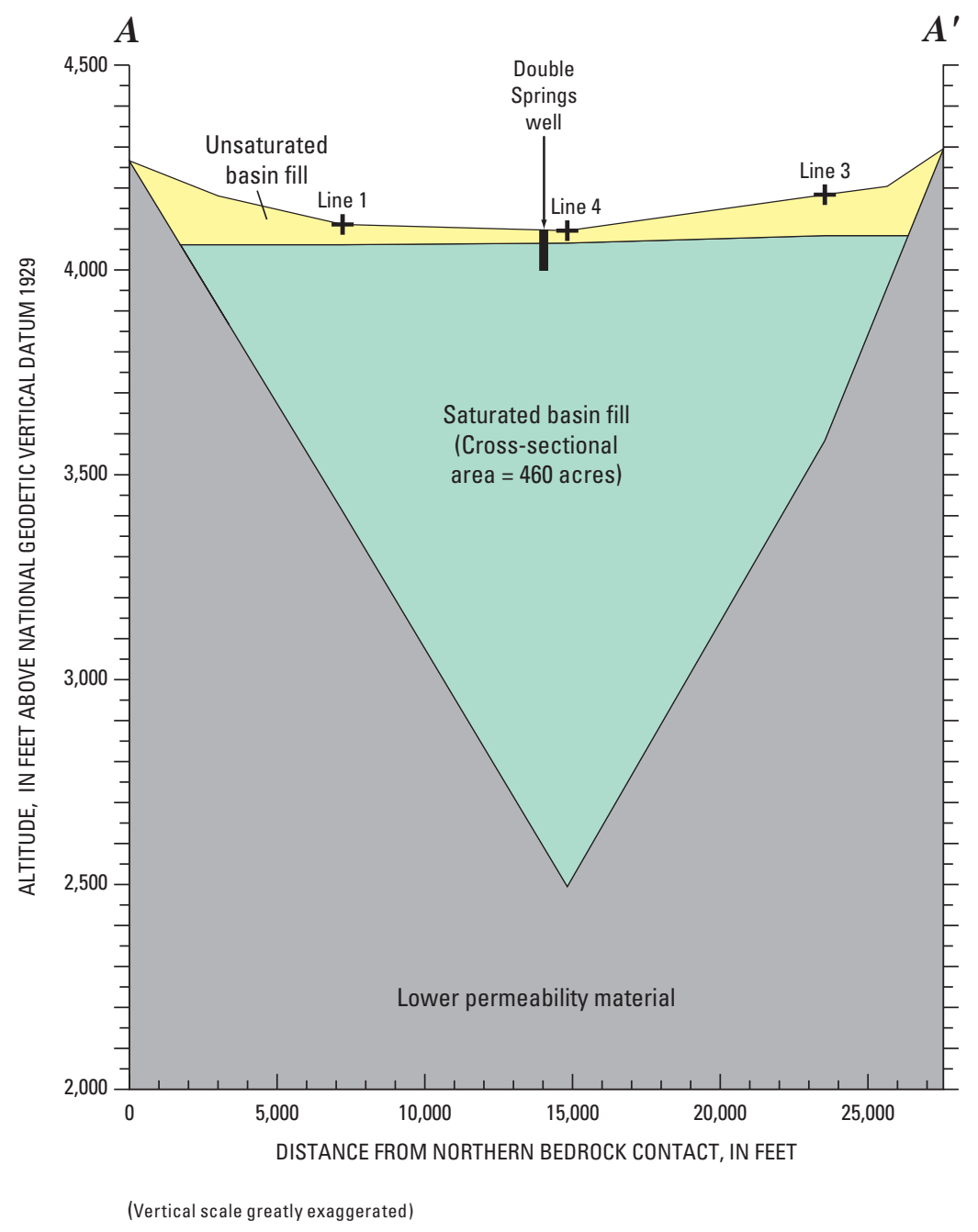

Figure 37. The Double Spring, Nevada, area. $A$ is the north end and $A^{\prime}$ is the south end of the cross section (see fig. 23). Lower permeability material includes semiconsolidated sediment, tight clay, and bedrock. Lines 1, 3, and 4 are locations of seismicrefraction lines.

feet thick near the toe of alluvial fans, about $430 \mathrm{ft}$ thick near the center of the area, and has a cross-sectional area of about 150 acres.

Alluvium is about 6.2 mi wide north of Walker Lake. Unsaturated alluvium is about zero feet thick at the Walker River and about $460 \mathrm{ft}$ thick near bedrock in the Gillis Range (fig. 39). Saturated alluvium is an asymmetric wedge that is zero feet thick near bedrock outcrops, about 2,000 ft thick near the Wassuk Range, and has a cross-sectional area of about 530 acres. 


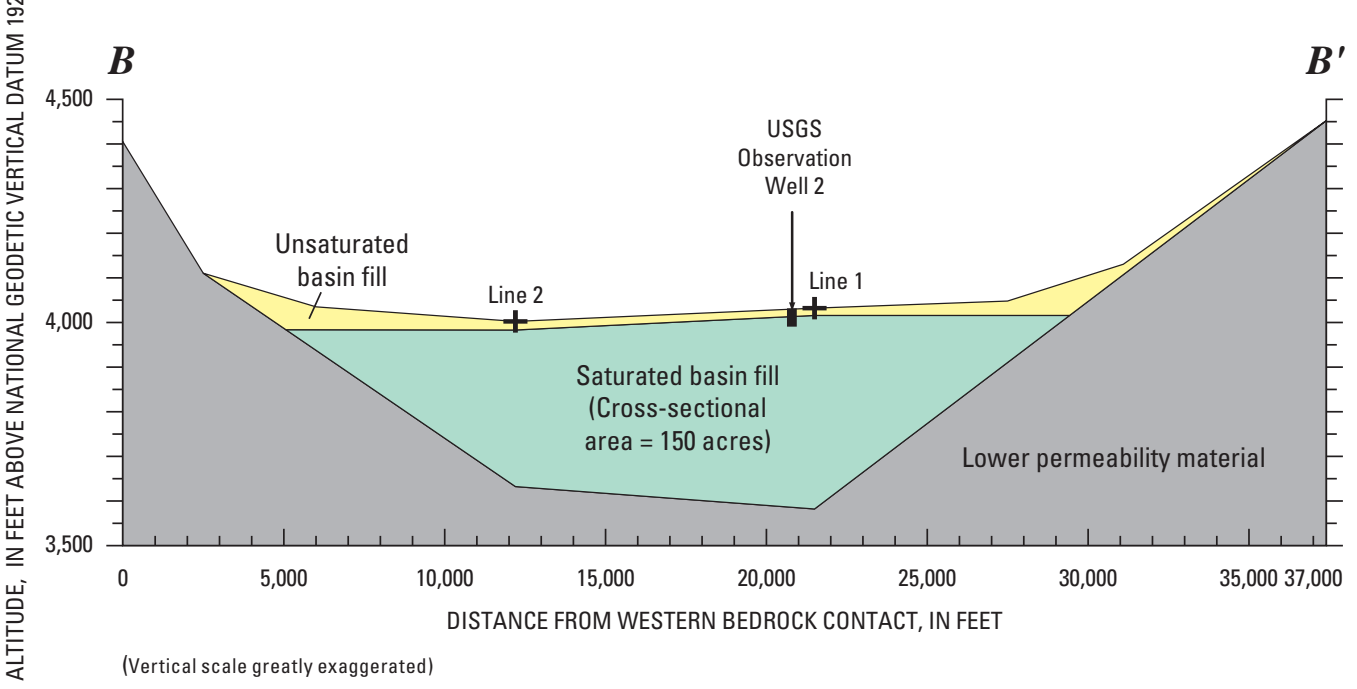

Figure 38. The area south of Walker Lake, Nevada.

$B$ is the west end and $B^{\prime}$ is the east end of the cross section (see fig. 23). Lower permeability material includes semiconsolidated sediment, tight clay, and bedrock. Lines 1 and 2 are locations of seismicrefraction lines.

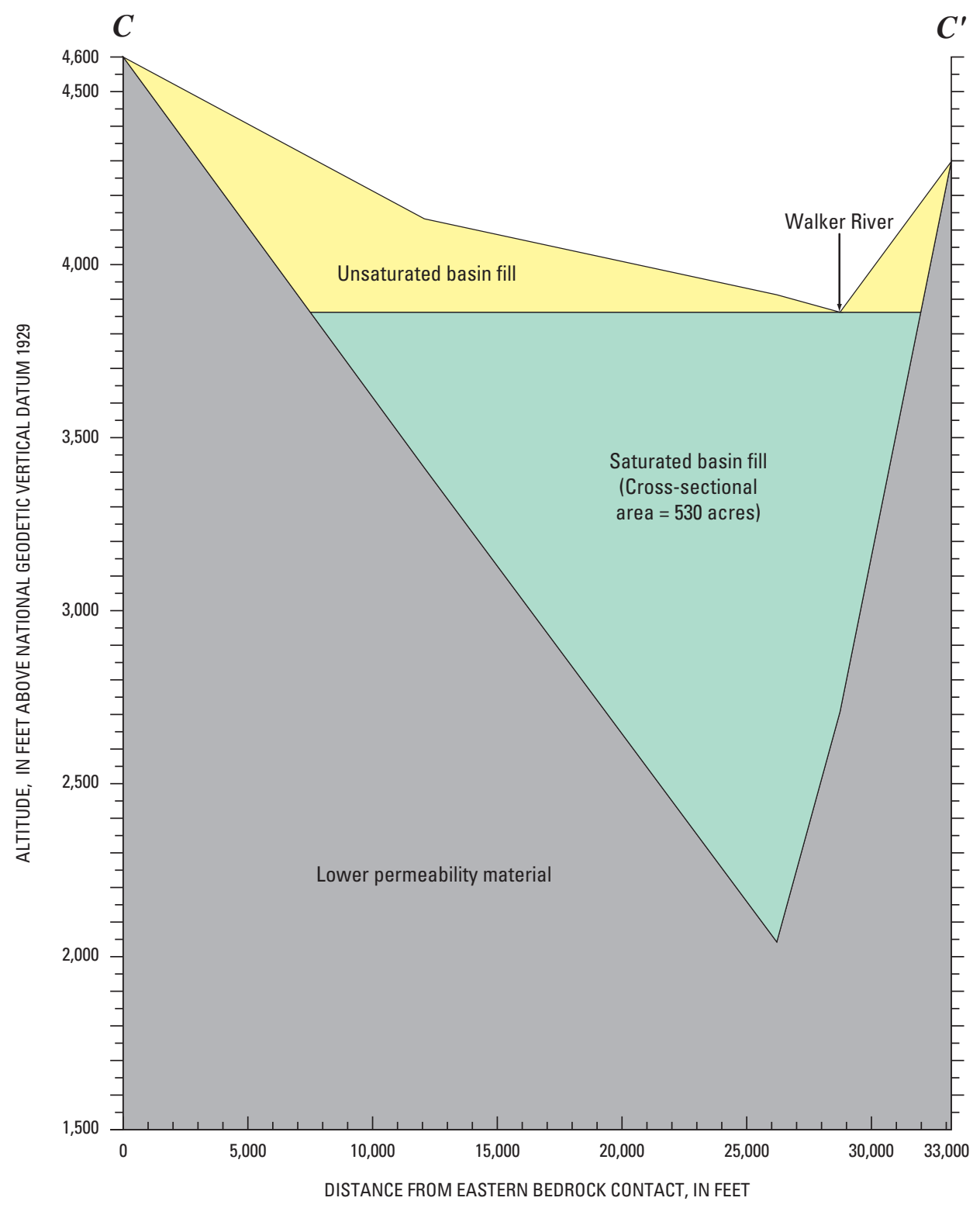

Figure 39. The area north of Walker Lake, Nevada. $C$ is the east end and $C^{\prime}$ is the west end of the cross section (see fig. 23). Lower permeability material includes semiconsolidated sediment, tight clay, and bedrock. (Modified from Blair and McPherson, 1994.) 


\section{Hydraulic Properties}

Re-analysis of slug-test data from the Army Depot using the KGS method resulted in hydraulic conductivity values that range from 2 to $40 \mathrm{ft} / \mathrm{d}$ with a mean of $10 \mathrm{ft} / \mathrm{d}$ (table 5, first section). Original estimates made using the method of Cooper and others (1967) ranged from 2 to $100 \mathrm{ft} / \mathrm{d}$ with an average of
$30 \mathrm{ft} / \mathrm{d}$, which are nearly identical to estimates from specificcapacity tests north of Walker Lake (Schaefer, 1980). The average hydraulic conductivity using the KGS method was 66 percent lower than the original estimates. No systematic problems could explain the differences, which could represent the accuracy and assumptions of the methods used to analyze the data.

Table 5. Results of slug tests from the lower Walker River basin, Nevada.

[Original hydraulic conductivity estimated using Cooper and others (1967). Abbreviations: USGS, U.S. Geological Survey; KGS, KGS method (Halford and Kuniansky, 2002); HAAD, Hawthorne Army Ammunition Depot; -, does not apply]

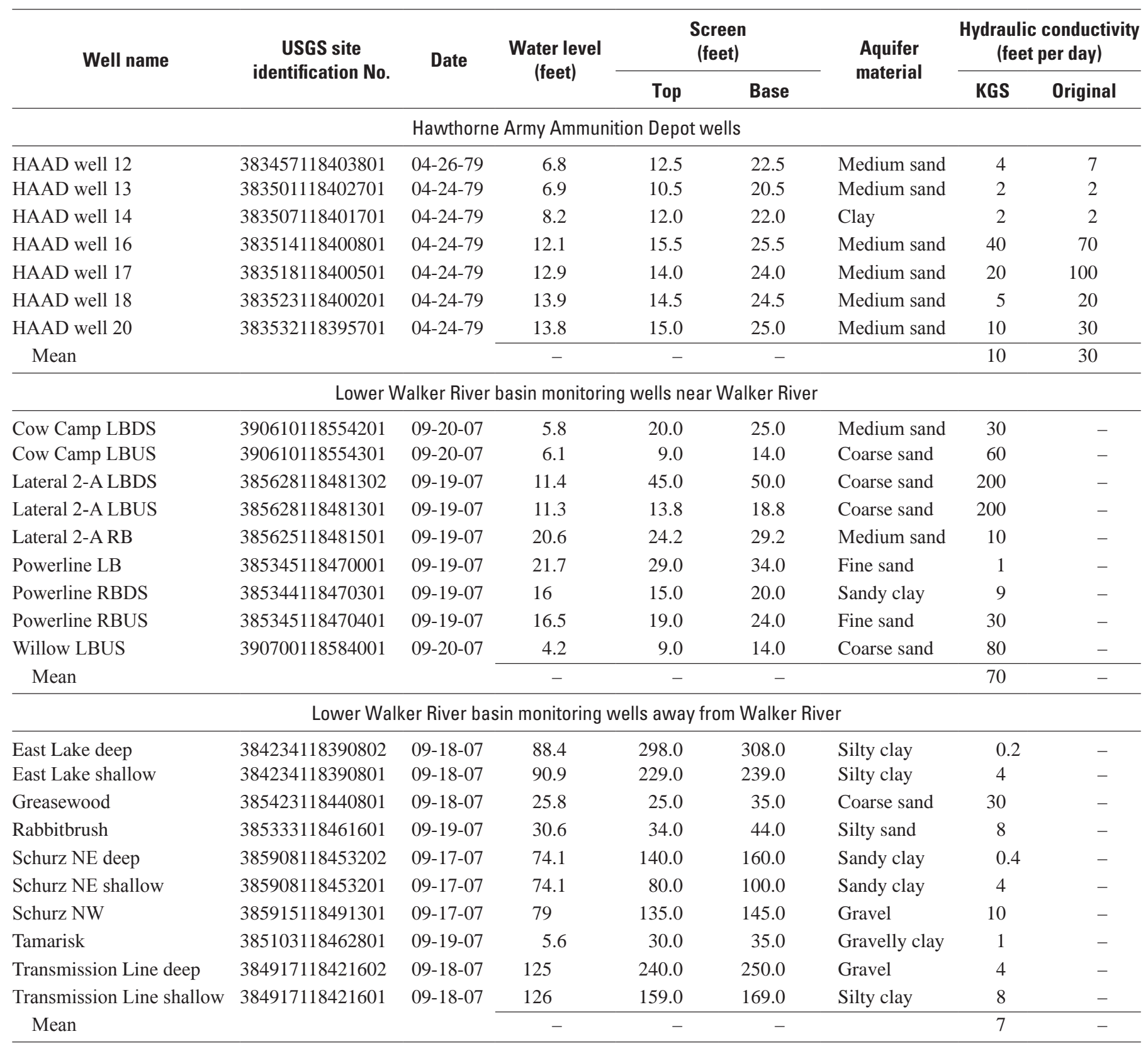


Except for Army Depot well 14, wells were screened in fine to coarse sand with thinly interbedded clay. Hydraulic conductivities of 2-100 ft/d are within the extreme ranges for medium sand (Bouwer, 1978; Domenico and Schwartz, 1990) and likely represent actual variability among the sites. The hydraulic conductivity for well 14 is $2 \mathrm{ft} / \mathrm{d}$, which is much greater than the maximum value for clay (Wolff, 1982; Domenico and Schwartz, 1990). The lithology of well 14 was described as clay, but 90 percent of drill cuttings were not recovered. The lithology of the entire screened interval was likely similar to other sites.

Estimated hydraulic conductivities in the Schurz area generally are consistent with the lithology of screened intervals. Wells screened in fine to coarse sand had hydraulic conductivities that ranged from 1 to $200 \mathrm{ft} / \mathrm{d}$. Two wells were screened in gravel, yet hydraulic conductivities were $4 \mathrm{ft} / \mathrm{d}$ and $10 \mathrm{ft} / \mathrm{d}$. Both wells were drilled with mud rotary so clay could be present but difficult to detect due to the drilling method. Wells screened in silty, sandy, or gravelly clay had a mean hydraulic conductivity of $4 \mathrm{ft} / \mathrm{d}$ with a maximum of $8 \mathrm{ft} / \mathrm{d}$, higher than the extreme maximum of $6 \mathrm{ft} / \mathrm{d}$ for silt or loess (Domenico and Schwartz, 1990).

Hydraulic conductivity at wells along the Walker River ranged from 1 to $200 \mathrm{ft} / \mathrm{d}$ with a mean of $70 \mathrm{ft} / \mathrm{d}$ (table 5 , second section). Away from the river, hydraulic conductivities ranged from 0.2 to $30 \mathrm{ft} / \mathrm{d}$ with a mean of $7 \mathrm{ft} / \mathrm{d}$ (table 5 , third section). Higher hydraulic conductivities along the Walker River could be due to a higher degree of sorting and coarser texture compared to other parts of the valley floor.

The aquifer in the Double Spring area consists of strata of sand and gravel separated by thick strata of clay. Transmissivity at the Double Spring well was $10,000 \mathrm{ft}^{2} / \mathrm{d}$ using the Theis method. The saturated thickness of alluvium ranged from 900 to 1,600 ft (fig. 37). Dividing transmissivity estimates by the saturated thickness yields a range in hydraulic conductivity of $6-10 \mathrm{ft} / \mathrm{d}$ with a mean of $8 \mathrm{ft} / \mathrm{d}$. These values are similar to average hydraulic conductivities estimated from slug tests south of Walker Lake and distant from the Walker River in the Schurz area.

Results of the aquifer test south of Schurz indicate that the horizontal hydraulic conductivity is about $50 \mathrm{ft} / \mathrm{d}$ for sand and gravel and $0.8 \mathrm{ft} / \mathrm{d}$ for silt and clay, similar to results of the slug tests. The thickness of each strata was used to estimate a weighted-average hydraulic conductivity of $30 \mathrm{ft} / \mathrm{d}$. The estimated transmissivity of $10,000 \mathrm{ft}^{2} / \mathrm{d}$ is the same value estimated at Double Spring. The vertical hydraulic conductivity was estimated to be $6 \mathrm{ft} / \mathrm{d}$ but likely ranges between $0.1 \mathrm{ft} / \mathrm{d}$ and $10 \mathrm{ft} / \mathrm{d}$ due to uncertainty in anisotropy.

The average horizontal hydraulic conductivity of the valley floor generally is from about 10 to $30 \mathrm{ft} / \mathrm{d}$ throughout the basin except immediately adjacent to the Walker River. Fluvial sediments along the Walker River have a mean hydraulic conductivity of about $70 \mathrm{ft} / \mathrm{d}$. Hydraulic conductivity can vary by an order of magnitude among sites. Aquifer and slug tests were not done on alluvial slopes.

\section{Subsurface-Flow Estimates}

Subsurface outflow (Q) through Double Spring and into Walker Lake was estimated using Darcy's Law (Fetter, 1980):

$$
\mathrm{Q}=\mathrm{KIA} \text {, }
$$

where

$\mathrm{K}$ is the hydraulic conductivity of the aquifer;

$\mathrm{I}$ is the hydraulic gradient; and

$A$ is the cross-sectional area.

Uncertainty in subsurface flow was estimated using a range of 10-30 ft/d for the average horizontal hydraulic conductivity of the valley floor. The cross-sectional area is about 460 acres at Double Spring. The hydraulic gradient was estimated using the difference in groundwater altitudes between the Double Spring well and the Schurz NE shallow well (385908118453201) and the sand dune well (385605118440601). The gradient ranged from 0.0006 to 0.001 (3.1 to $5.6 \mathrm{ft}$ per mile) with an average of 0.0008 ( $4.4 \mathrm{ft}$ per mile). Subsurface flow through Double Spring ranges from 1,000 to $5,000 \mathrm{acre}-\mathrm{ft} / \mathrm{yr}$ with an average of 2,700 acre-ft/yr. In comparison, Schaefer (1980) estimated 4,500 acre-ft/yr of subsurface flow through Double Spring.

The cross-sectional area south of Walker Lake is 150 acres. A hydraulic gradient of 0.004 was estimated using the difference in groundwater altitudes between USGS well 1 (383624118385801) and USGS well 2 (383550118382201). Using a range of 10-30 ft/d for the average horizontal hydraulic conductivity, subsurface discharge is from about 2,200 to 6,600 acre-ft/yr with an average of 4,400 acre-ft/yr.

The cross-sectional area north of Walker Lake is 530 acres (fig. 39). The hydraulic gradient was estimated using the difference in groundwater altitudes between Walker Lake and the tamarisk well (385103118462801), between the 3,090 and 4,010 water-level contours, and between the 4,010 and 4,020 water-level contours (pl. 1). The gradient ranged from 0.0026 to 0.0027 with an average of 0.0027 . Using a range of $10-30 \mathrm{ft} / \mathrm{d}$ for the average horizontal hydraulic conductivity, subsurface flow ranges from 5,000 to 15,700 acre-ft/yr with an average of 10,400 acre-ft/yr. In comparison, Schaefer (1980) estimated 11,000 acre-ft/yr of subsurface flow from the north of Walker Lake.

\section{Groundwater Quality}

Two wells in consolidated-rock aquifers were sampled for this study. The dissolved-solids concentration was $457 \mathrm{mg} / \mathrm{L}$ at the Gillis well, less than the secondary drinking-water standard of $500 \mathrm{mg} / \mathrm{L}$ (U.S. Environmental Protection Agency, 2008a). Total uranium activity was $14.4 \mathrm{pCi} / \mathrm{L}$. Other alpha emitters such as ${ }^{226} \mathrm{Ra}$ may be present and could exceed drinking-water standards. The dissolved-solids concentration of the domestic well in Walker Gap (Walker Gap domestic, 390914119060601 ; $591 \mathrm{mg} / \mathrm{L}$ ) exceeded the secondary drinking-water standard. 
${ }^{222} \mathrm{Rn}$ was not measured in the Gillis well but was $690 \mathrm{pCi} / \mathrm{L}$ in the domestic well, which exceeds the proposed drinkingwater standard of $300 \mathrm{pCi} / \mathrm{L}$ (U.S. Environmental Protection Agency, 2008b). No other constituents that were measured exceeded primary or secondary drinking-water standards.

Dissolved-solids concentrations vary considerably in unconsolidated sediments in the lower Walker River basin. Concentrations ranged from 158 to $620 \mathrm{mg} / \mathrm{L}$ in fluvial sediments along the Walker River and the valley floor at the Schurz NW well (385915118491301). The highest concentration was from the Willow ET well (390658118583801) at the Willow site. Most samples were collected during July and August 2006 at the end of the spring runoff, which was more than twice the 1971-2000 streamflow normal at the Wabuska gage. The lowest dissolved-solids concentrations in fluvial sediments were similar to the concentration in Weber Reservoir (146 mg/L), indicating groundwater was recently recharged streamflow.

Away from the river, dissolved-solids concentrations in the alluvial aquifer typically were greater than $1,000 \mathrm{mg} / \mathrm{L}$. The highest concentrations were north and northeast of Schurz, Nev., at the Calico Hills well (390049118464801; 5,780 mg/L), Schurz NE shallow well (385908118453201; 3,190 mg/L), and Schurz NE deep well (385908118453202; 3,760 mg/L). An unnamed spring south of Schurz (385031118462801), the Double Spring well, and other wells distant from the river had from 651 to 2,650 mg/L of dissolved solids.

Dissolved-solids concentrations around Walker Lake are similar to concentrations away from the Walker River. East and northeast of Walker Lake, groundwater had from 1,470 to $1,650 \mathrm{mg} / \mathrm{L}$ of dissolved solids. A domestic well (Walker Lake domestic, 383902118451301) at the toe of the Cottonwood Creek alluvial fan was sampled in 2003 and had $893 \mathrm{mg} / \mathrm{L}$ of dissolved solids.

Lopes (2006) determined that groundwater discharge areas in Nevada tend to have high (greater than 1,000 mg/L) concentrations of dissolved solids. High dissolved-solids concentrations are due to ET, which concentrates dissolved solids and results in water that is isotopically heavier than the source water (Coplen and others, 2000). A positive correlation between dissolved-solids concentrations and $\delta \mathrm{D}$ values would be expected if ET is controlling dissolvedsolids concentrations, but the Spearman rank correlation $(-0.12)$ was not significant. Dissolved-solids concentrations had strong (greater than 0.95) Spearman rank and Pearson correlations with sodium, bromide, chloride, and sulfate, indicating dissolution of evaporative salts. The driller's log for the Calico Hills well describes a $1 \mathrm{ft}$ thick stratum of salt at a depth of $130 \mathrm{ft}$, which likely precipitated from Lake Lahontan during a dry period. The distribution of salts and dilution from infiltrated streamflow seem to have the greatest effect on dissolved-solids concentrations in the alluvial aquifer.
Most wells with greater than 1,000 mg/L dissolved solids exceeded secondary drinking-water standards of $250 \mathrm{mg} / \mathrm{L}$ for sulfate, $250 \mathrm{mg} / \mathrm{L}$ for chloride, and $2 \mathrm{mg} / \mathrm{L}$ for fluoride. Three wells exceeded the secondary standard for iron $(0.3 \mathrm{mg} / \mathrm{L})$ and seven wells exceeded the secondary standard for manganese $(0.05 \mathrm{mg} / \mathrm{L})$. $\mathrm{pH}$ was 9.6 at the Double Spring well and 8.8 at the greasewood well (385423118440801), which exceeded the secondary drinking-water standard of 6.5-8.5 standard units. Five wells had total uranium activities of $18.6-156 \mathrm{pCi} / \mathrm{L}$. Both wells in unconsolidated sediment that were sampled for ${ }^{222} \mathrm{Rn}$ exceeded the proposed standard of $300 \mathrm{pCi} / \mathrm{L}$. A Cow Camp site well (390610118554301) had $630 \mathrm{pCi} / \mathrm{L}$ and the Willow ET well had $800 \mathrm{pCi} / \mathrm{L}$ of ${ }^{222} \mathrm{Rn}$. Other alpha emitters likely are present and could exceed drinking-water standards. No other constituents that were measured exceeded primary or secondary drinking-water standards.

\section{Depth to Water}

Depth to groundwater in the Walker River basin generally is less than $20 \mathrm{ft}$ adjacent to Walker River and less than $50 \mathrm{ft}$ under most of the valley floor from Smith Valley to Walker Lake (fig. 40). Depth to groundwater is less than $5 \mathrm{ft}$ in northwestern Mason Valley near Adrian Gap where groundwater discharges. Depth to water is $50-100 \mathrm{ft}$ under the valley floor between the West Fork of the Walker River and Artesia Lake and where sand dunes have formed east of Schurz. Depth to water increases to $100-300 \mathrm{ft}$ under the valley floor around Hawthorne and along the alluvium/ consolidated-rock contact in most of the basin. Groundwater is deeper than $500 \mathrm{ft}$ along mountains in Smith Valley, the Desert and Terrill Mountains, the Gillis and Wassuk Ranges, and Agai Pah Hills.

After the 2004 irrigation season, groundwater levels were an average of $9 \mathrm{ft}$ lower in Smith Valley and $4 \mathrm{ft}$ lower in Mason Valley compared to pre-irrigation levels (fig. 41). The 2004 irrigation season was the last year of a 5-year drought, so intensive pumpage to supplement streamflow caused large water-level declines in both valleys. Between autumn 2004 and spring 2005, groundwater levels recovered an average of $6 \mathrm{ft}$ in Smith Valley and $3 \mathrm{ft}$ in Mason Valley. After the 2005 irrigation season, groundwater levels were an average of $1.5 \mathrm{ft}$ lower in Smith Valley and $2 \mathrm{ft}$ higher in Mason Valley. The 2005 runoff was about average at the Wabuska gage (fig. 25), so there was less pumpage compared to 2004. Between autumn 2005 and spring 2006, water levels recovered an average of $3.5 \mathrm{ft}$ in Smith Valley and rose another $2.5 \mathrm{ft}$ in Mason Valley. After the 2006 irrigation season, water levels rose an average of $2 \mathrm{ft}$ in both Smith and Mason Valleys due to recharge from the high spring runoff and reduced pumpage. 


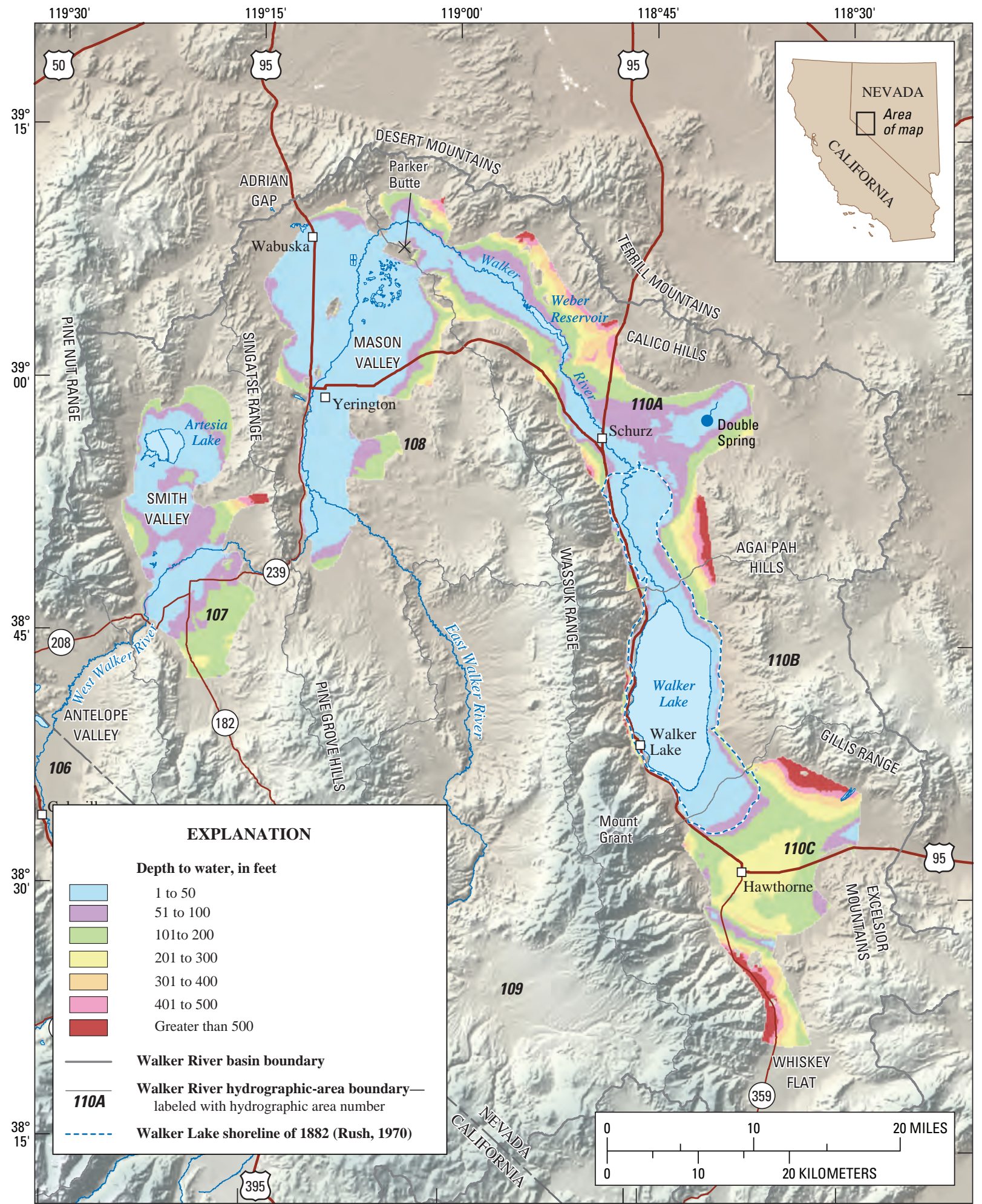

Base from U.S. Geological Survey digital data, 1:24,000 and 1:100,000, 1978-88. Walker Lake average lake altitude of $3937.5 \mathrm{ft}$ for November 2006; Projection: Universal Transverse Shuttle Radar Topography Mission digital data, 2000.

Figure 40. Depth to water in Smith and Mason Valleys, and the lower Walker River basin, Nevada. 


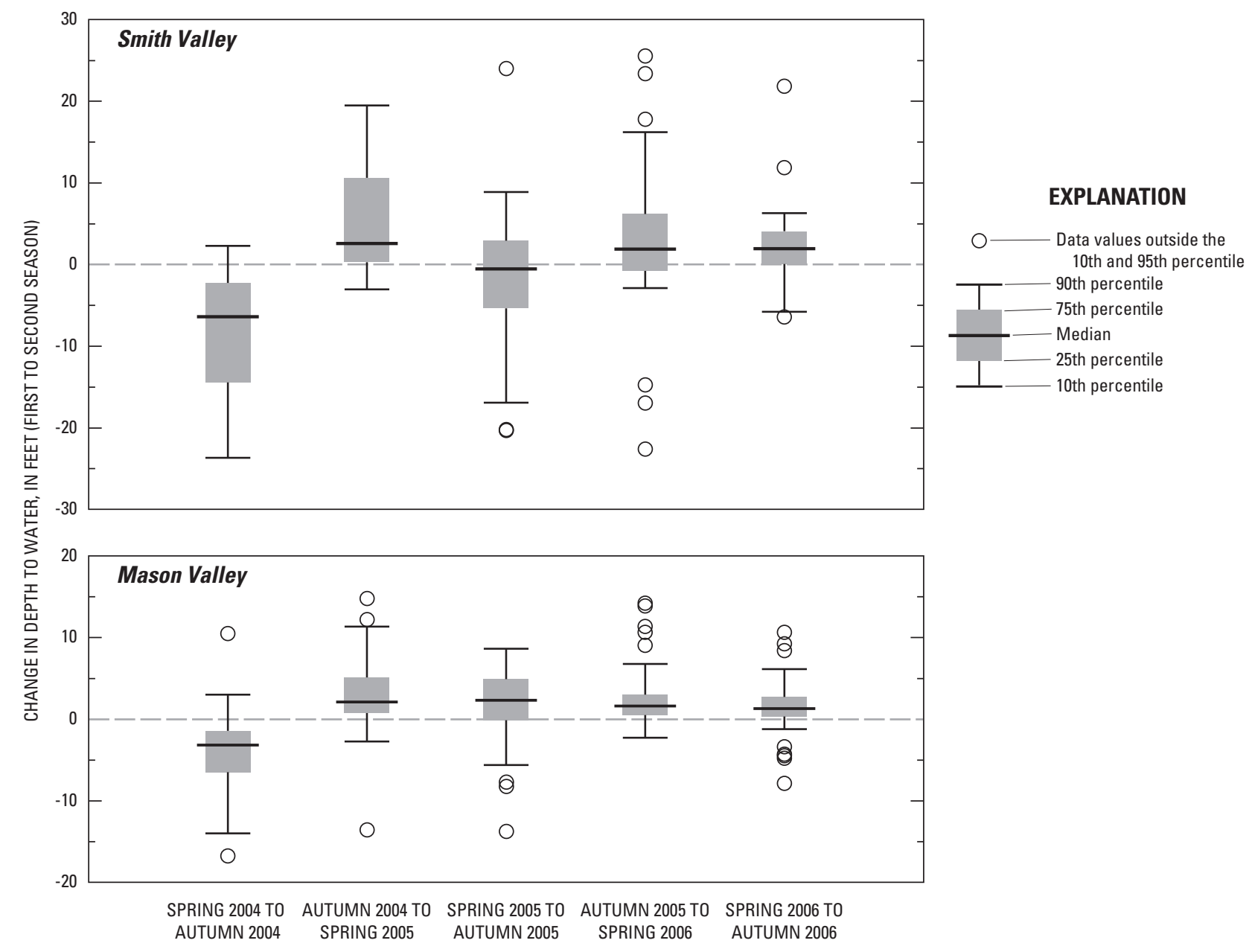

Figure 41. Change in depth to water in Smith and Mason Valleys, Nevada, following the 2005 and 2006 irrigation seasons. Negative values indicate the water table declined and positive values indicate the water table recovered.

Drillers' logs for the flowing wells in Smith Valley describe strata of blue and gray clay up to $110 \mathrm{ft}$ thick that likely were deposited when Lake Wellington occupied the valley during the Pleistocene (Reheis, 1999). Drawdown due to pumpage is greater for confined aquifers than unconfined or semiconfined aquifers (Freeze and Cherry, 1979), so a confined-aquifer system would explain the 9 -ft decline in water levels after the 2004 irrigation season. In comparison, water levels in Mason Valley declined an average of $4 \mathrm{ft} \mathrm{after}$ the 2004 irrigation season. This decline is small considering three to four times more groundwater is pumped from Mason Valley than Smith Valley (Gallagher, 2005) and Mason Valley receives only 2,000 acre-ft/yr of recharge from precipitation (Huxel and Harris, 1969) compared to 17,000 acre-ft/yr in Smith Valley (Rush and Schroer, 1976). The small decline in water levels indicates a semiconfined aquifer system in Mason Valley with infiltration from the river and ditches.
Groundwater is pumped for irrigation in Smith and Mason Valleys even during years with high runoff. For a 10-year period (1994-2003), pumpage in Smith Valley ranged from 10,300 to 33,200 acre-ft/yr with a mean of 23,100 acre-ft/yr (Gallagher, 2005). Pumpage in Mason Valley ranged from 41,400 to $123,700 \mathrm{acre}-\mathrm{ft} / \mathrm{yr}$ with a mean of 76,800 acre-ft/yr.

Pumpage decreased logarithmically as streamflow increased, indicating a minimum pumpage of about $10,000 \mathrm{acre}-\mathrm{ft} / \mathrm{yr}$ in Smith Valley and 40,000 acre-ft/yr in Mason Valley (fig. 42). Three times the minimum value is pumped when streamflow is much less than average. Fields solely irrigated with groundwater typically use a center pivot and are identified as circular fields on Landsat imagery. During 2000, Smith Valley had 933 acres of circular fields and Mason Valley had 136 acres. Assuming an application rate of 4 acre-ft/yr/acre, about 3,700 acre-ft/yr is pumped at circular fields in Smith Valley and 540 acre-ft/yr in Mason Valley. 


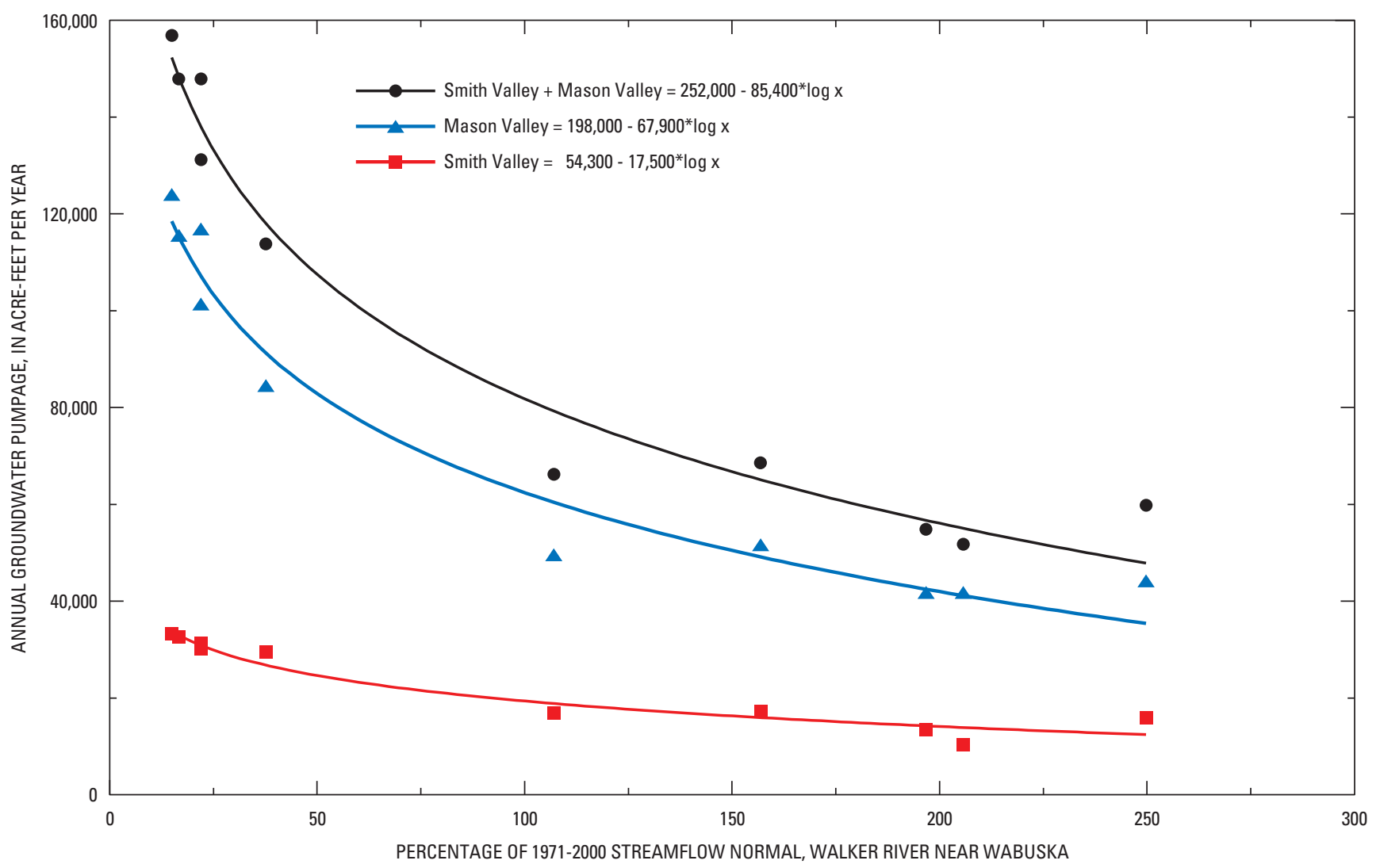

Figure 42. Groundwater pumpage in Smith and Mason Valleys compared with streamflow of the Walker River near Wabuska, Nevada (10301500). Pumpage and streamflow data are for 1994-2003. The 1971-2000 streamflow normal is 138,000 acre-ft/yr.

Thus, minimum annual pumpages include pumpage directly into ditches for flood irrigation.

Groundwater levels and aquifer storage have been declining in most of Smith and Mason Valleys since 1960 (fig. 43A). Total declines in water levels for some wells are as much as $60 \mathrm{ft}$ along the margins of the basins and $20 \mathrm{ft}$ near the Walker River. The Nevada Division of Water Resources analyzed trends in water levels and determined that 3 wells (12 percent) in Smith Valley have stable water levels and 22 wells (88 percent) have declining water levels ${ }^{3}$ (fig. 44). In Mason Valley, 15 wells (27 percent) have stable water levels and 40 wells ( 73 percent) have declining water levels. The largest declines occurred during droughts from 1987 to 1994 and 2000 to 2004 when groundwater was pumped intensively. Stable water levels in Smith Valley are difficult to explain because stable and declining water levels occur in wells adjacent to canals and wells closest to the West Fork of the Walker River are declining. In Mason Valley, most wells with stable water levels are within $0.25 \mathrm{mi}$ of a canal and near the

\footnotetext{
${ }^{3}$ http://water.nv.gov/well\%20net/download_data.cfm, accessed May 7, 2009.
}

Walker River. Wells with declining water levels are farther from the Walker River.

No wells on the Reservation were measured routinely prior to 2004, so changes in groundwater levels were evaluated by comparing initial levels when wells were drilled to the latest measurements and to the altitude of Walker Lake in 1882 (table 6). The latest groundwater levels mostly are within a few feet of initial levels and do not show a trend (neither lower nor higher), indicating generally no change during the past 40-50 years. Large declines in groundwater levels would be expected near the 1882 shoreline because of the $150-\mathrm{ft}$ decline in Walker Lake. Agai Pah (385342118443201) and Powerline Rd \#1 (385342118473101) were drilled at an altitude of 4,080 $\pm 10 \mathrm{ft}$, about the same altitude of Walker Lake in 1882 $(4,082 \mathrm{ft})$ estimated by Lopes and Smith (2007). Assuming the 1882 groundwater altitude was 4,082 ft at Agai Pah and Powerline $\mathrm{Rd} \# 1$, then groundwater levels declined from about 30 to $40 \mathrm{ft}$ before these wells were drilled.

South of Walker Lake, groundwater levels have declined a total of $10-15 \mathrm{ft}$ at a fairly constant rate $(0.2-0.3 \mathrm{ft} / \mathrm{yr})$ since 1952 (fig. 43B). Spurious water levels that are below the general trend of the data may have been influenced by nearby pumpage at the time of measurement. During the early 1980s, 
A. Smith and Mason Valleys
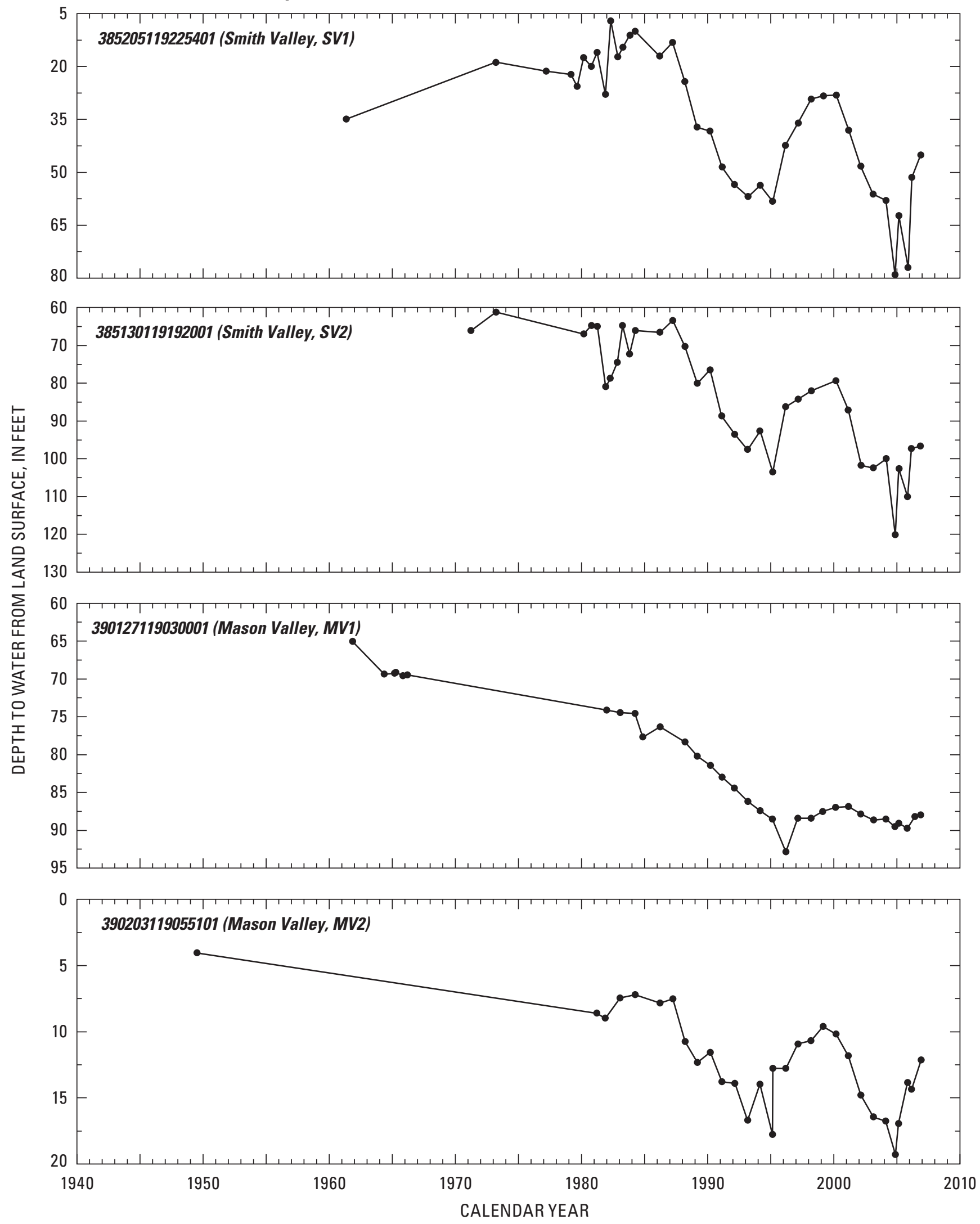

Figure 43. Time series of depth to water in $(A)$ Smith and Mason Valleys and $(B)$ the Hawthorne area, Nevada. The 15-digit number is the U.S. Geological Survey site number for the well. Well locations are shown in figure 22. 


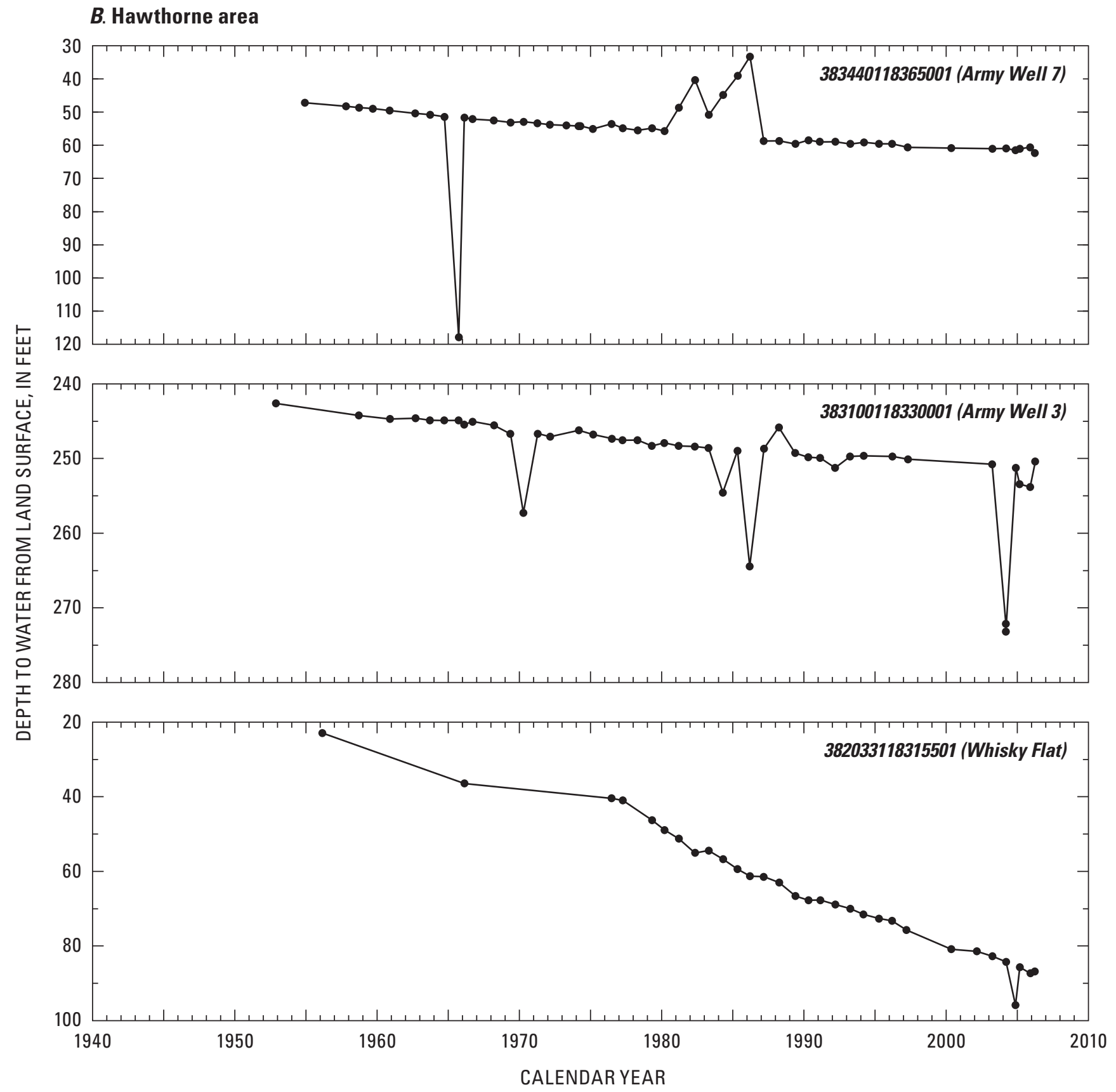

Figure 43.-Continued. 


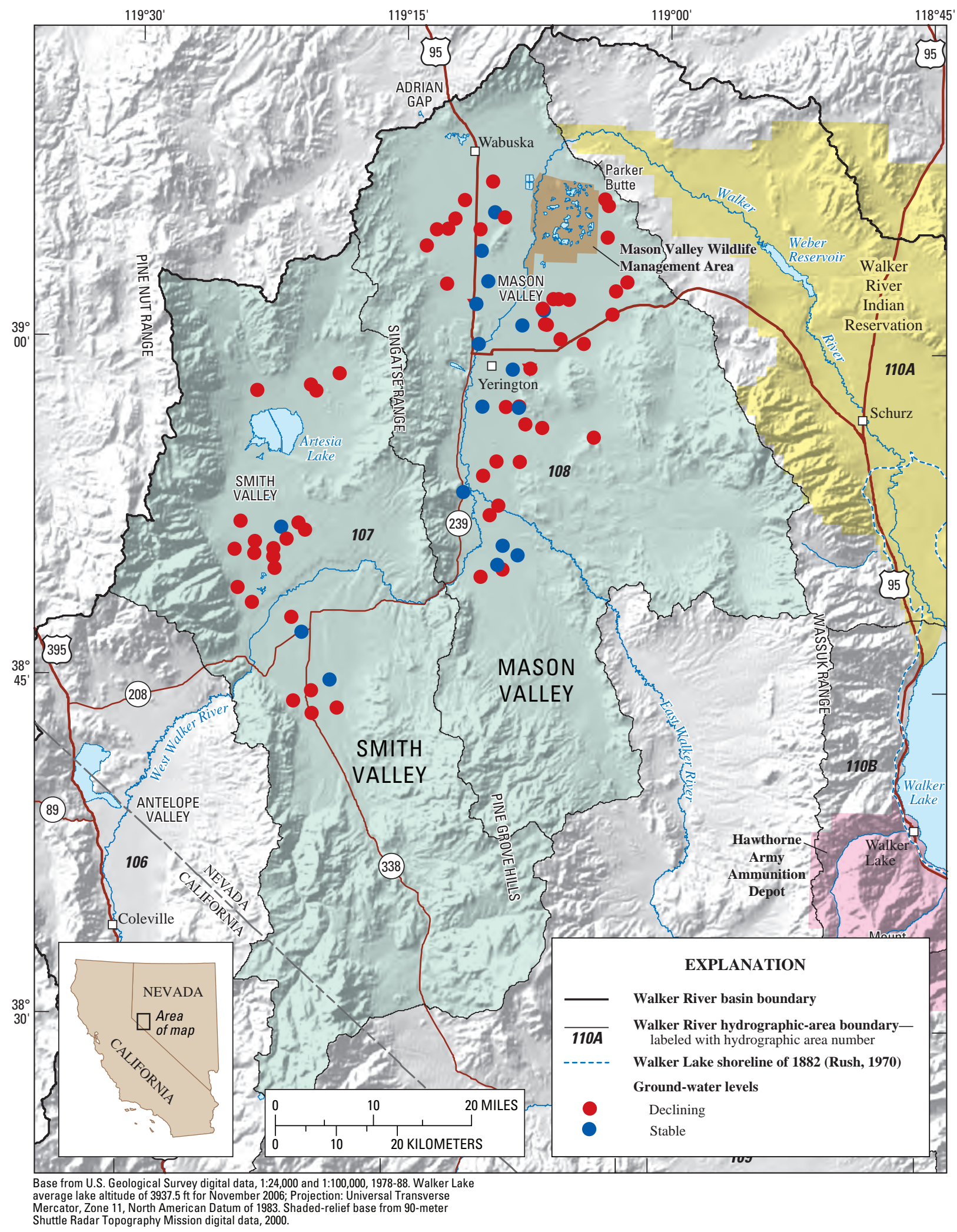

Figure 44. Locations of wells with either declining or stable water levels in Smith and Mason Valleys, Nevada. 
Table 6. Initial and latest water-level data for selected wells near Schurz, Nevada.

\begin{tabular}{|c|c|c|c|c|c|c|c|}
\hline Well name & Station No. & $\begin{array}{l}\text { Land-surface } \\
\text { elevation } \\
\text { (feet) }\end{array}$ & $\begin{array}{l}\text { Well depth } \\
\text { (feet) }\end{array}$ & \multicolumn{2}{|c|}{ Initial water-level data } & \multicolumn{2}{|c|}{ Latest water-level data } \\
\hline Agai Pah & 385342118443201 & 4,080 & 500 & 27 & 04-05-92 & 27.02 & $12-04-06$ \\
\hline Powerline Road \#1 & 385342118473101 & 4,080 & 375 & 35.5 & $10-07-77$ & 35.56 & $12-04-06$ \\
\hline Koegel Hills & 385430118290401 & 4,400 & 502 & 458 & 01-14-66 & 461.31 & 03-02-05 \\
\hline Heartfalls Well C & 385637118463501 & 4,140 & 114 & 55 & $11-17-77$ & 50.03 & 01-08-07 \\
\hline Well A Sunset & 385756118485001 & 4,170 & 124 & 55 & $08-15-77$ & 54.43 & $12-06-06$ \\
\hline Red Earth & 385840118500101 & 4,130 & 60 & 7 & $09-01-67$ & 9.27 & 01-08-07 \\
\hline Calico Hills & 390049118464801 & 4,240 & 212 & 150 & $01-10-66$ & 141.84 & $12-04-06$ \\
\hline Julian well & 391052119034101 & 4,340 & 103 & 64 & $12-16-55$ & 66.43 & 01-08-07 \\
\hline
\end{tabular}

the 20-ft rise in the level of Army Well 7 (383440118365001) coincides with a 16-ft increase in the level of Walker Lake. The rapid response likely is due to a confined aquifer system that is connected hydraulically to the lake. Army Well 7 is about $4 \mathrm{mi}$ southeast and at least $150 \mathrm{ft}$ higher than the elevation of Walker Lake. The 20-ft rise may be due to recharge upgradient from the well superimposed on the increase in lake stage.

Groundwater levels in the Whisky Flat area have declined $70 \mathrm{ft}$ since 1956 (fig. 43B). These wells are 16-20 mi south and 1,500 ft higher than the elevation of Walker Lake. The declines likely are due to pumpage for municipal and agricultural uses.

\section{Walker Lake}

Walker Lake is oval shaped with a north-south trending long axis. The minimum altitude of the bottom is 3,849 ft near the center of the lake (Lopes and Smith, 2007). On December 1,2008 , the lake-surface altitude was $3,930.6 \mathrm{ft}$, maximum depth was $81.6 \mathrm{ft}$, storage was 1,621,000 acre-ft, and the surface area was 31,290 acres.

The lake bottom is steepest along the western shore, moderately steep along the eastern shore, shallowest at the northern and southern ends, and becomes fairly flat about $0.3 \mathrm{mi}$ from the western and eastern shores (Lopes and Smith, 2007). Scour channels up to $425 \mathrm{ft}$ wide were observed near the mouth of the Walker River. Deltaic sediments created a broad mound up to $6.5 \mathrm{ft}$ tall and $1 \mathrm{mi}$ wide that extends about 3 mi south from the mouth of the Walker River. The rest of the lake bottom remarkably is smooth, except for mounds near the river mouth and shore.

Mounds near the mouth of the Walker River could be stumps of trees that grew during long periods of low lakesurface altitude (Adams, 2007) or partially buried logs carried in from the river. Some of the mounds, especially those near the western shore, likely are boulders that tumbled into the lake or were deposited by prograding alluvial fans during long periods of low lake-surface altitude. Piles of boulders were observed along the shore south of the town of Walker Lake and in water about $30 \mathrm{ft}$ deep (Lopes and Smith, 2007).

Single-beam sonar anomalies were detected in the deepest parts of Walker Lake, miles from the river mouth and shore (fig. 45; Lopes and Smith, 2007). Sonar return signals from the anomalies were the same as signals from boulders or other solid objects lying on the bottom. However, sidescan sonar and scuba divers did not detect anything. The lake was well mixed when bathymetry was done and there is no indication that the equipment malfunctioned, so the cause of the anomalies is unknown.

Ninety-three mounds and anomalies between $3 \mathrm{ft}$ and $32 \mathrm{ft}$ tall were detected in Walker Lake (Lopes and Smith, 2007). Two groups of mounds and anomalies were detected in the northern and southern parts of the lake. The northern group extends from the northwestern to mid-eastern sides of Walker Lake and is aligned with the southern end of a northwest trending fault that crosses the Wassuk Range. This fault or associated fault strands could continue southeast and underlie the lake. The southern group extends from about 2.5 mi northeast of the town of Walker Lake to the southern end of the lake. The steep slope north of the town of Walker Lake likely is a fault scarp. The northwest trend parallel to and in proximity of mapped faults suggests that anomalies could be related to faults.

Lake-surface altitudes in Mono and Walker Lakes were compared to qualitatively determine the effect of diversions on Walker Lake. The Walker River had been diverted for 20 years and Mason Valley was developed fully prior to the first reliable measurement of Walker Lake in 1882 (Russell, 1885). Streams in the Mono Basin also had been diverted, but large diversions did not start until 1941 when the Los Angeles Department of Water and Power started diverting water from 


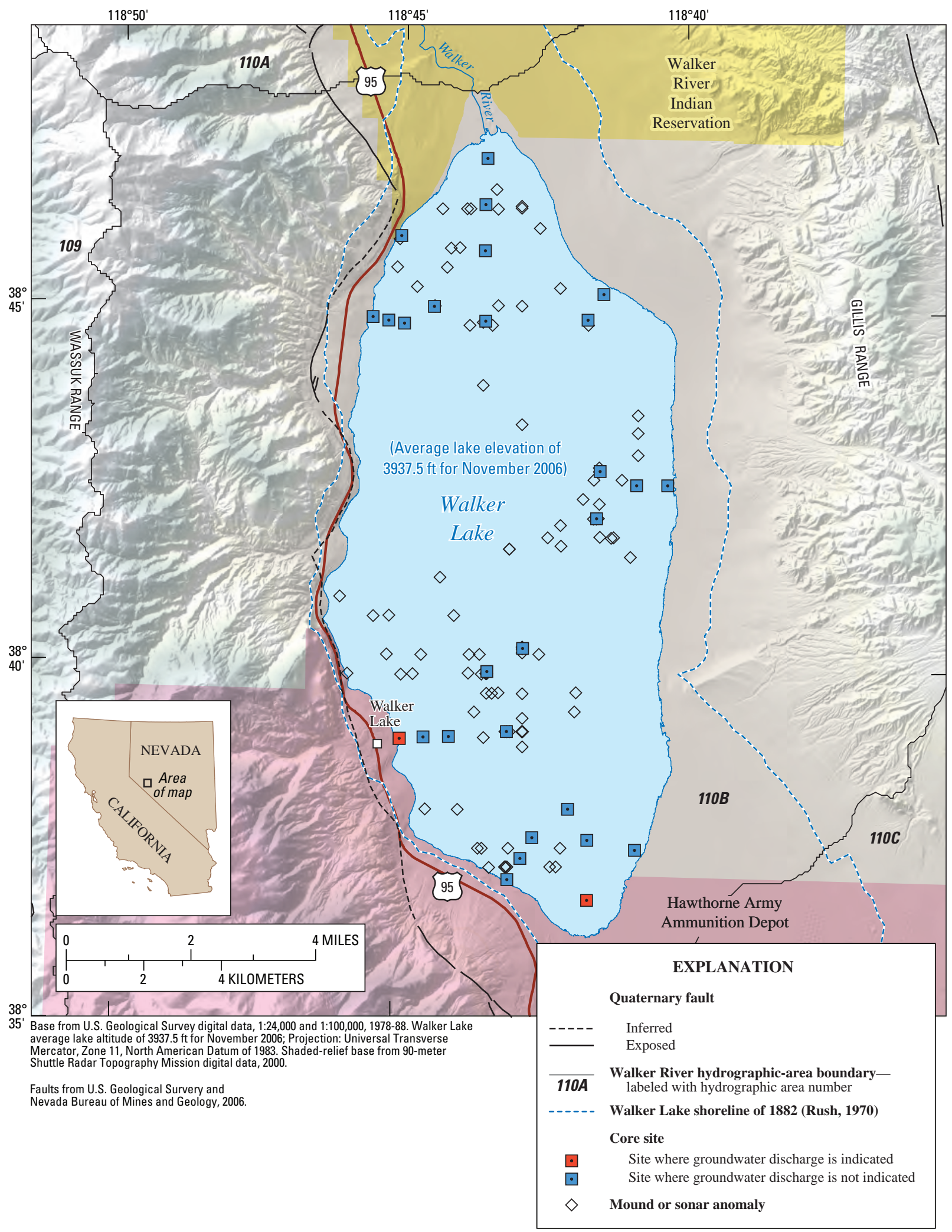

Figure 45. Locations of core sites and mounds or anomalies detected using single-beam sonar, Walker Lake, Nevada. (Lopes and Smith, 2007.) 
the basin. A 60-year period (1882-1941) provides the best measure of the effect of diversions on Walker Lake.

Walker Lake declined gradually until the early 1920s when reservoirs were built on the Walker River (fig. 20). Since construction of the reservoirs, Walker Lake has had a sharp, steady decline except during occasional wet periods. In contrast, Mono Lake rose from 1882 to about 1920 when the level started a gradual decline until the mid-1930s. The 1920s through mid-1930s was a period of extended drought (Harding, 1965), which also would have contributed to the decline in Walker Lake. However, Mono Lake did not decline to its 1882 level until 1949, 8 years after diversions started. Mono Lake declined sharply from 1949 until 1982 when the lake started recovering due to a series of wet years and court orders required minimum inflows from tributary streams. In comparison, Walker Lake continued its sharp decline.

Comparison between the levels of Walker and Mono Lakes indicate that the decline of Walker Lake primarily is due to diversions and the use of reservoirs to store and more efficiently manage water for irrigation. This interpretation is supported by Milne's (1987) estimates of what lake levels would be without diversions, and Yuan and others' (2006) results showing changes in total and inorganic carbon concentrations and $\delta^{13} \mathrm{C}$ and $\delta^{18} \mathrm{O}$ of inorganic carbon and ostracods in lake sediments. The timing of the steep decline in lake level and chemical composition of sediments coincided with construction of reservoirs on the Walker River and was attributed to a change in the hydrologic budget.

The proportion of major ions in Walker Lake has not changed appreciably since 1882. Samples collected by Russell (1885) and this study on August 1, 2006, had about equal equivalents of chloride, sulfate, and carbonate species. Sodium comprises about 90 percent of cations.

Specific conductance of Walker Lake has been measured more often than dissolved solids. Linear regression was done using data when both parameters were measured concurrently to estimate dissolved solids (DS), in milligrams per liter, from specific conductance ( $\mathrm{SpC}$ ond), in microsiemens per centimeter. The regression equation had an adjusted $R^{2}$ of 0.86 and standard error of $810 \mathrm{mg} / \mathrm{L}$ :

$$
\text { DS }=0.76 * \text { SpCond }-270 \text {. }
$$

Much of the dissolved-solids concentrations during 1980-90 (fig. 3) were estimated from specific-conductance measurements and equation 5.

\section{Conceptual Hydrologic Model of the Walker River Basin}

The conceptual hydrologic model is a description of the sources of inflow and outflow from the Walker River basin, locations of hydrologic divides between the Walker River basin and adjacent basins, groundwater-flow directions, and flow between the Walker River and alluvial aquifers. This conceptual model forms the basis of estimating the amount of water needed to attain a specific dissolved-solids concentration in Walker Lake and to predict effects of changes in irrigation practices.

The hydrology of the lower Walker River basin is considerably different than the upper basin. The upper basin has alluvial valleys separated by mountains of consolidated rock with low hydraulic conductivity. The alluvial aquifer in each valley thins or pinches out at the downstream end, forcing most groundwater to discharge into the river. Streamflow is gaged where the river enters and exits the valleys, and the amount of subsurface flow between valleys is a small percentage of the streamflow. Understanding where water is used in each valley is difficult due to the complex system of canals and ditches, but the gaged streamflow makes estimating overall water use within each valley a relatively easy task. In contrast, the lower Walker River basin is best characterized as a single interconnected surface-water/ groundwater system from the Wabuska gage to Walker Lake. The Walker River has losing and gaining reaches, and the alluvial aquifer has no structures that force most groundwater into the river. The surface-water/groundwater interactions and unobstructed flow through the alluvial aquifer makes it difficult to determine the direction and amount of subsurface flow at certain locations in the lower Walker River basin. For this report, the alluvial aquifer of the lower Walker River basin is described for three reaches of the Walker River: Wabuska-Little Dam, Little Dam-Lateral 2-A, and Lateral 2-A-Walker Lake.

\section{Sources of Water and Outflow}

Most water in the lower Walker River basin originates as snowmelt from the Sierra Nevada. Local precipitation falls directly on Walker Lake, the valley floor, and the Wassuk and Gillis Ranges. However, precipitation rates are low, soil 
permeability is high, and the Army Depot diverts streams in the Wassuk Range so local runoff seldom reaches the Walker River or Walker Lake. A fraction of the local precipitation becomes natural recharge, but the amount of recharge is small compared to inflow from the Walker River (Everett and Rush, 1967). Induced recharge occurs from infiltration of diverted water along unlined canals and ditches, infiltration of excess water applied to crops, and infiltration of septic effluent.

Most outflow from the lower Walker River basin occurs by ET and subsurface discharge through the Double Spring area. About 70 percent of the ET is evaporation from Walker Lake (Allander and others, 2009). ET from natural and agricultural vegetation, subsurface outflow, and pumpage for domestic and stock water use account for the remaining 30 percent of outflow. Outflow from aquifers occurs by ET from phreatophytes, pumpage from irrigation, municipal, domestic, and stock wells, and subsurface flow to Walker Lake and alluvial aquifers east of Schurz.

The importance of evaporation on the hydrologic cycle of the lower Walker River basin is demonstrated by the isotopic data. $\delta^{2} \mathrm{H}$ (deuterium) and $\delta^{18} \mathrm{O}$ values in groundwater typically have a slope of 8 and plot parallel to the Global Meteoric Water Line (Craig, 1961). The intercept of the line can vary from the global average of 10 , primarily depending on latitude. Most $\delta^{2} \mathrm{H}$ and $\delta^{18} \mathrm{O}$ values in Nevada's groundwater are spread around the Global Meteoric Water Line and become more negative with increasing latitude, altitude, and well depth (Lopes, 2006).

During evaporation, lighter isotopes preferentially fractionate into the vapor phase. Along a flow path, evaporation produces residual water that becomes progressively heavier than the source water and has $\delta^{2} \mathrm{H}$ and $\delta^{18} \mathrm{O}$ values that plot along a line with a slope between 3 and 6 (Coplen and other, 2000). The slope decreases as the intensity of evaporation increases. The intersection of the evaporation line with the Global Meteoric Water Line indicates the isotopic composition of the source water.

Isotopic data indicate surface water and groundwater in the lower Walker River basin are from two sources that have evaporated (fig. 46). Data from the Walker River, groundwater along the Wassuk Range, and Walker Lake plot along an evaporation line with a slope of 5.7. Walker Lake is the residual from evaporation of streamflow and groundwater from the Walker River and Wassuk Range. Groundwater along

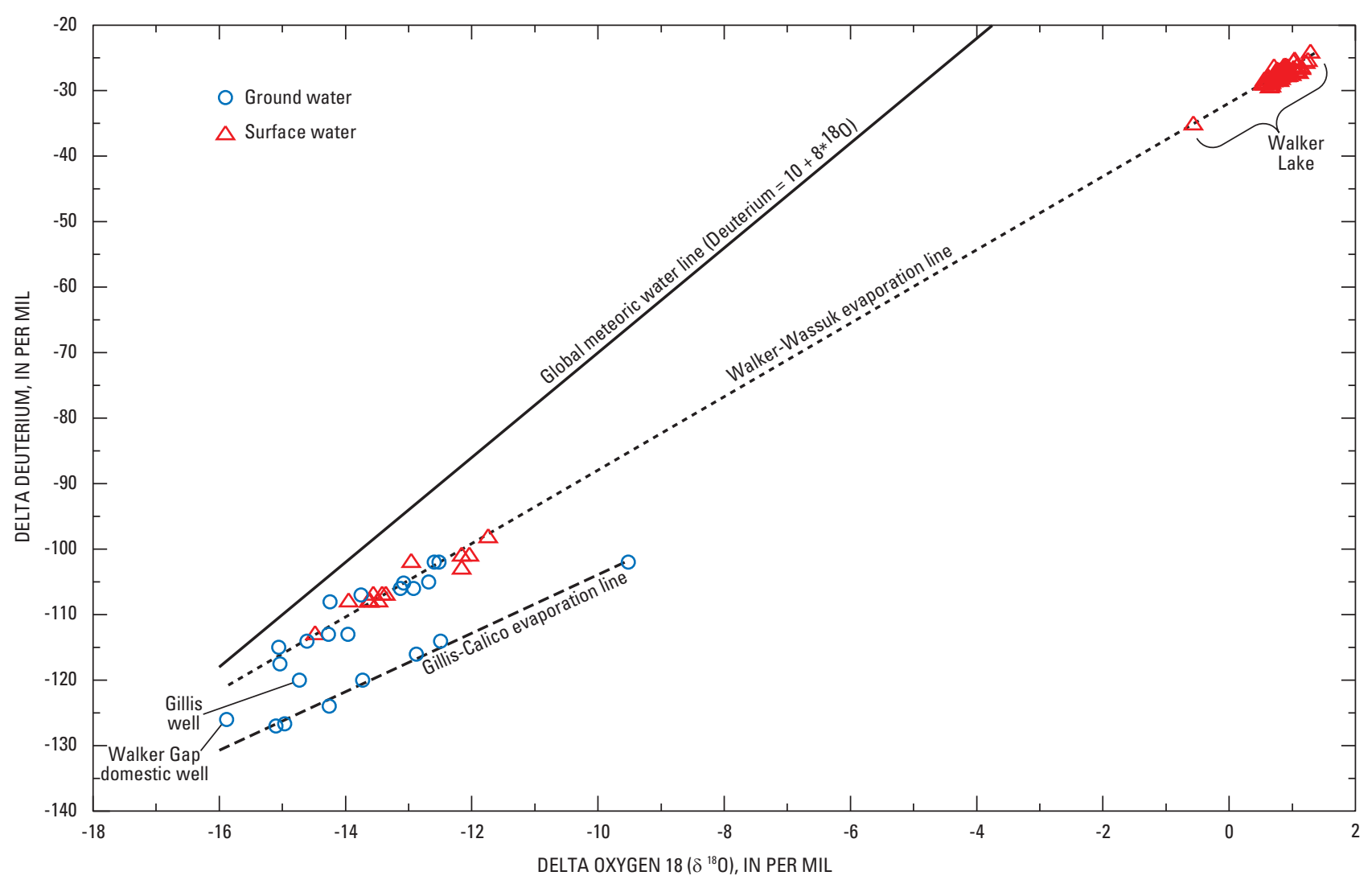

Figure 46. Oxygen and hydrogen isotopes in groundwater and surface water from the lower Walker River basin, Nevada. 
the Gillis Range and Calico Hills plots along an evaporation line with a slope of 3.8, indicating more intense evaporation and that these are not significant sources of water to the lake. If they were significant, then Walker Lake would be a mix of the two sources and plot between the two evaporation lines.

Heavier isotopes preferentially fractionate into precipitation as storms move inland from the oceans (Coplen and others, 2000). As a result, residual moisture in storms becomes progressively lighter with distance inland. Isotopic fractionation as storms cross the Sierra Nevada and Pine Nut, Sweetwater, and Wassuk Ranges could explain the lighter isotopic composition of the Gillis-Calico evaporation line.

The lighter isotopic composition also could be due to mixing of modern-day recharge with Pleistocene-age groundwater. The Pleistocene was wetter and evaporation rates were lower than the modern-day climate, so it is unlikely that Pleistocene-age recharge would plot along the Gillis-Calico evaporation line unless it had mixed with modern-day recharge. Smith and others (2002) state that modern-day precipitation in northwestern Nevada has $\delta^{2} \mathrm{H}$ values from -100 to $-120 \%$. Groundwater that is $20 \%$ more negative than modern precipitation probably is Pleistocene age and groundwater that is $10-19 \%$ more negative possibly is Pleistocene age. The lightest $\delta^{2} \mathrm{H}$ value measured in the lower Walker River basin was -127 \% from the East Lake Deep well (384234118390802) between Walker Lake and the Gillis Range. The Gillis well is upgradient and 1,000 ft higher than the East Lake Deep well and had a $\delta^{2} \mathrm{H}$ value $-120 \%$, which is about $5 \%$ heavier than expected from the Gillis-Calico evaporation line. Local precipitation is the only source of recharge for the Gillis well, because Pleistoceneage groundwater at this elevation is unlikely. Thus, the lighter isotopic composition of the Gillis-Calico evaporation line could be due to mixing of recent recharge with Pleistoceneage water.

\section{Consolidated-Rock Aquifers and Groundwater Divides}

Groundwater from Walker Gap domestic, which is screened in fractured basalt, had a $\delta^{2} \mathrm{H}$ value of $-126 \%$ and $\delta^{18} \mathrm{O}$ value of $-15.9 \%$. These data plot between the two evaporation lines and indicate a mixture of recharge from the Walker River and Desert Mountains, which presumably have an isotopic composition similar to the Gillis Range and Calico Hills (fig. 46). The warm groundwater $\left(80^{\circ} \mathrm{F}\right)$ indicates recharge also could be mixed with geothermal water. A $\delta^{18} \mathrm{O}$ value of $-15.9 \%$ corresponds to a $\delta^{2} \mathrm{H}$ value of $-122 \%$ for the Walker-Wassuk evaporation line and -130\%o for the GillisCalico evaporation line. The $\delta^{2} \mathrm{H}$ value of $-126 \%$ is mid-way between these values, indicating the basalt has 50 percent river water and 50 percent recharge from the Desert Mountains. Fractured basalt in this area likely produces large quantities of water because of recharge from the river, which is not typical of consolidated-rock aquifers.
The Gillis well is more representative of consolidatedrock aquifers and provides useful information on consolidatedrock aquifers and groundwater flow around Walker Lake. The well demonstrates that groundwater is present in consolidated rocks, presumably where they have been fractured, and recharge to consolidated-rock aquifers occurs where precipitation normals are as little as 7-11 in. (fig. 17). Much of the Wassuk Range receives 11-16 in/yr of precipitation and has a similar amount of faulting compared to the Gillis Range (fig. 30). The higher precipitation rates likely result in more recharge to consolidated-rock aquifers in the Wassuk Range.

Although there is recharge, the low hydraulic conductivity of most types of consolidated rocks (Maurer and others, 2004) and the low yield of the Gillis well indicates consolidated-rock aquifers in the lower Walker River basin store and transmit little water. This low yield could be due partly to overburden pressure closing fractures and greatly decreasing the hydraulic conductivity of intrusive rocks between $100 \mathrm{ft}$ and $200 \mathrm{ft}$ below land surface (Freeze and Cherry, 1979).

Groundwater altitudes in the Gillis and Wassuk Ranges are at least 1,000 ft higher than the surface of Walker Lake. Groundwater divides must be present to separate recharge that flows towards Walker Lake from recharge that flows towards adjacent valleys. Groundwater divides would prevent water from flowing through the consolidated rocks surrounding Walker Lake to adjacent valleys. Outflow from consolidatedrock aquifers occurs as subsurface discharge to alluvial aquifers, baseflow to perennial streams such as Cottonwood Creek, and ET from aspen and other vegetation living along perennial reaches.

\section{Alluvial Aquifers}

Water-table contours indicate that groundwater in the Walker River basin generally flows downvalley with a component of flow towards the Walker River in gaining reaches, a component of flow away from the river in losing reaches, and flow parallel to the river with no groundwater flowing through the streambed in stable reaches (pl. 1). Watertable contours were interpreted assuming that the Walker River is connected to the shallow aquifer along all reaches but one. A losing reach between the Little Dam and Powerline gages has intermittent flow that depends on releases from Weber Reservoir. Periods of no flow indicate this reach is disconnected intermittently from the shallow aquifer.

This study confirmed previous findings that some flow in alluvial aquifers discharges from the Walker River basin through Adrian Gap in northwestern Mason Valley (Huxel and Harris, 1969) and through Double Spring east of Schurz, Nev. (Schaefer, 1980). Compared to previous studies, the largest change in groundwater-flow directions occurred in Mason Valley. 


\section{Smith Valley}

In addition to infiltration of Walker River streamflow, the alluvial aquifer in Smith Valley is recharged from the Pine Nut and Sweetwater Ranges. The Singatse Range and Pine Grove Hills that separate Smith and Mason Valleys, reach altitudes of $6,700 \mathrm{ft}$ and $8,500 \mathrm{ft}$, respectively, and receive from 9 to $12 \mathrm{in} / \mathrm{yr}$ of precipitation. Precipitation on these mountains recharges alluvial aquifers in Smith and Mason Valleys. The surrounding mountains are comprised of consolidated rocks with low hydraulic conductivity (Maurer and others, 2004). Groundwater likely exists where consolidated rocks have been fractured, and groundwater divides and the low hydraulic conductivity form barriers to groundwater flow between the valleys.

In Smith Valley, the configuration of the water table mapped in the spring of 1972 (Rush and Schroer, 1976) is nearly the same as the one mapped in the autumn of 2006 (pl. 1). Groundwater-flow directions have changed little even though the water table has dropped as much as $60 \mathrm{ft}$ in some locations (fig. 43A). A groundwater divide between the West Fork of the Walker River and Artesia Lake separates two alluvial-aquifer systems in northern Smith Valley. Groundwater north of the divide flows north and discharges by ET from native vegetation, agricultural vegetation irrigated with groundwater, and the playa surface. Groundwater south of the divide and in southern Smith Valley is pumped from irrigation and supply wells or discharges to the West Fork of the Walker River. The alluvial aquifer pinches out at Wilson Canyon near the Hudson gage.

Water-table contours indicate that almost the entire reach of the West Fork of the Walker River is gaining through Smith Valley. Fifteen wells in Smith Valley were flowing when drilled from 1948 to 2006. Most flowing wells are within $2 \mathrm{mi}$ of the West Fork of the Walker River or near Artesia Lake. Artesian conditions indicate a confined-aquifer system with an upward gradient, which is consistent with water-table contours indicating groundwater discharge to the West Fork of the Walker River and Artesia Lake.
Although water levels indicate the river is gaining, there are periods when the gradients are reversed and groundwater levels are below the channel resulting in streamflow infiltration along this reach. Pumpage has lowered water levels throughout Smith Valley so wells may flow only during wet periods when heads in the aquifer have risen above land surface. For example, depth to water was $22 \mathrm{ft}$ when a well (SV artesian, 384743119204901) was drilled in 1991, but this well was flowing in 1999 after 5 years of above average runoff.

\section{Mason Valley}

The alluvial aquifer in Mason Valley is recharged mostly by infiltration of Walker River streamflow and from precipitation on the Singatse Range, Pine Grove Hills, and northwestern Wassuk Range. The water-table configuration changed between 1965-66 (Huxel and Harris, 1969) and autumn 2006 (pl. 1). The change could be due to pumpage altering groundwater-flow directions, differences in data interpretation, or both. In 1965-66 and autumn 2006, watertable contours indicate the West Fork of the Walker River was gaining and the East Fork of the Walker River was mostly stable. In 1965-66, most of the Walker River was gaining through Mason Valley with a short stable reach near Yerington. In contrast, the Walker River was losing in autumn 2006 except for a short gaining reach just upstream from the Wabuska gage where the alluvial aquifer nearly pinches out.

On November 28, 2005, instantaneous stream discharge was measured to determine the amount of groundwater discharge in the reach between the northern end of the Management Area and the Wabuska gage. Discharge was measured at three locations in the Walker River and in two tributaries (table 7). Measurements were repeated three times at each site, except at the Wabuska Drain above Walker River Confluence near Parker Butte, Nev. (Wabuska Drain, 10301495). Discharge at the Wabuska gage varied by $1 \mathrm{ft}^{3} / \mathrm{s}$ (from 64 to $65 \mathrm{ft}^{3} / \mathrm{s}$ ) during the time measurements were made and ranged from 63 to $70 \mathrm{ft}^{3} / \mathrm{s}$ during the 3 days prior to measurements.

Table 7. Discharge data from Walker River basin, Nevada, November 28, 2005.

[Discharge and standard deviation, in cubic feet per second. Method: acoustic, acoustic velocity meter; pygmy, pygmy meter. Abbreviation: -, does not apply]

\begin{tabular}{|c|c|c|c|c|c|c|c|c|}
\hline \multirow[t]{2}{*}{ Station name } & \multirow{2}{*}{$\begin{array}{c}\text { Station } \\
\text { No. }\end{array}$} & \multirow[t]{2}{*}{ Method } & \multicolumn{3}{|c|}{$\begin{array}{l}\text { Discharge } \\
\text { measurement }\end{array}$} & \multirow{2}{*}{$\begin{array}{c}\text { Mean } \\
\text { discharge }\end{array}$} & \multirow{2}{*}{$\begin{array}{l}\text { Standard } \\
\text { deviation }\end{array}$} & \multirow{2}{*}{$\begin{array}{l}\text { Gain/ } \\
\text { loss }\end{array}$} \\
\hline & & & 1 & 2 & 3 & & & \\
\hline $\begin{array}{l}\text { Walker River above Wabuska Drain confluence near } \\
\text { Wabuska, Nev. }\end{array}$ & 10301400 & Pygmy & 54.6 & 52.7 & 51.7 & 53.0 & 1.5 & 0.0 \\
\hline $\begin{array}{l}\text { Wabuska Drain above Walker River Confluence near } \\
\text { Parker Butte, Nev. }\end{array}$ & 10301495 & Acoustic & 5.3 & - & - & 5.3 & - & \\
\hline Walker River near Wabuska, Nev. & 10301500 & Pygmy & 64.2 & 65.1 & 64.8 & 64.7 & .5 & 12.9 \\
\hline
\end{tabular}

${ }^{1}$ Difference between Walker River near Wabuska, Wabuska Drain, Perk/Joggles Slough, and Walker River above Wabuska Drain. 
Instantaneous discharge measurements indicate no groundwater discharge along the $1.5 \mathrm{mi}$ reach between the Management Area and the Perk/Joggles Slough. About $2.9 \mathrm{ft}^{3} / \mathrm{s}(2,100$ acre- $\mathrm{ft} / \mathrm{yr})$ of groundwater discharge was estimated along the $0.75 \mathrm{mi}$ reach between the Perk/Joggles Slough and the Wabuska gage, confirming that this is a gaining reach. Some of the $3.5 \mathrm{ft}^{3} / \mathrm{s}$ from the Perk $/$ Joggles Slough and $5.3 \mathrm{ft}^{3} / \mathrm{s}$ from the Wabuska Drain also could be groundwater discharge.

In 1965-66, water-level contours indicate groundwater flowed north from the hills east of Yerington with no apparent effect on groundwater flow direction due to constructed ponds and irrigation in the Management Area (Huxel and Harris, 1969). These hills receive less than $7 \mathrm{in} / \mathrm{yr}$ of precipitation (fig. 17), so significant recharge as indicated by the contours is unlikely. Some effect from ponds and irrigated fields on groundwater flow would be expected because the Management Area did not have wetlands until the Walker River was diverted (Elmer Bull, Wildlife Staff Specialist, Nevada Department of Wildlife, written commun., 2008). In autumn 2006, water-level contours indicate groundwater near Yerington flowed northeast away from the Walker River and through the Management Area. The water-table gradient is very shallow across the Management Area due to a broad mound in the water table formed by diverted water.

Both the 1965-66 and autumn 2006 water-level contours indicate subsurface outflow from northeastern Mason Valley through Walker Gap, where the Wabuska gage is located, and Parker Gap south of Parker Butte. Huxel and Harris (1969) estimated $700 \mathrm{acre}-\mathrm{ft} / \mathrm{yr}$ of subsurface outflow through Walker Gap and 700 acre-ft/yr through Parker Gap.

Huxel and Harris (1969) used the locations of 17 wells that were flowing in 1965-66 to map a large area of artesian flow in northernmost Mason Valley. Currently (2008), no known wells in the valley are flowing. The Mason Hot well (391004119093201) was flowing in 1966, but depth to water was $98 \mathrm{ft}$ in February 2008 indicating a large decrease in confined pressure. The water-level probe was hot indicating this well taps geothermal water. The Mason Hot well, Wabuska hot springs, a small geothermal power station, and the Churchill Hot well north of the Desert Mountains coincide with the Wabuska lineament, a zone of northeast-trending faults (dePolo and others, 1997). Geothermal water "may circulate along faults related to the Wabuska lineament as well as an unconformity above Mesozoic metasedimentary rocks possibly present at depth."

The large decrease in head could be due to pumpage from irrigation wells, wells at the geothermal power station, and wells at a fossil-fuel power station along the northwest boundary of the Management Area. The geothermal power station started operating in 1984, was expanded in 1987, and pumps from two wells less than $500 \mathrm{ft}$ deep in Quaternary gravels and sand (Sapp, 2007). In 2000, the geothermal power station pumped 2,360 acre- $\mathrm{ft}(3.2 \mathrm{ft} / 3 / \mathrm{s}$ ) of groundwater (Lopes and Evetts, 2004). The water is discharged to wetlands rather than reinjected into the aquifer. The fossil-fuel power station started operating in 1968 and has two wells $(611 \mathrm{ft}$ and $649 \mathrm{ft}$ deep) with permitted water rights of 5,400 acre-ft/yr. Until 1995 , groundwater pumped to cool steam generators had been continuously recycled in holding ponds until enough water had evaporated to pump freshwater (Horton, 1995). To reduce salt buildup, groundwater was pumped more frequently, placed in cooling ponds, and then as much as 2,500 acre-ft/yr is discharged to wetlands in the Management Area.

A groundwater divide separates two alluvial-aquifer systems in northwestern Mason Valley. The 1965-66 waterlevel contours indicate a groundwater divide that extends north and south from Mason Butte, a bedrock outcrop just west of the Management Area. Autumn 2006 waterlevel contours indicate a similar location for the divide. Groundwater between the Singatse Range and Mason Butte and north of Luzier Lane flows northwest towards Adrian Gap. Groundwater east of Mason Butte flows northeast towards the Wabuska gage, but most northeasterly flow seems to be towards the Mason Hot well and the Wabuska lineament. It is unclear how geothermal water could be circulating through the faults if the lineament is a pathway for nongeothermal water. Additional data are needed in northern Mason Valley to define groundwater flow directions, quantify subsurface outflow, and characterize water-level response to pumping.

Depth to water in the Wabuska area is less than $5 \mathrm{ft}$ and efflorescent salts form where groundwater evaporates from soils. Some groundwater and effluent from the geothermal powerplant is lost to ET from perennial ponds and moderately dense greasewood around Wabuska. The remainder is surface and subsurface discharge through Adrian Gap. Huxel and Harris (1969) estimated subsurface outflow through the Adrian Gap is 150 acre-ft/yr prior to effluent discharges.

Except during storms, groundwater discharge and effluent from the geothermal powerplant are the only sources of water for the intermittent stream in Adrian Valley, which flows into the Carson River basin. The stream likely is intermittent because ET during spring and summer causes groundwater levels to lower and groundwater discharge to decrease. During the winter of 2005-06, from about 1 to $2 \mathrm{ft}^{3} / \mathrm{s}$ (from 720 to $1,440 \mathrm{acre}-\mathrm{ft} / \mathrm{yr}$ ) was observed $3 \mathrm{mi}$ downstream from Adrian Gap. On February 6, 2008, $0.5 \mathrm{ft}^{3} / \mathrm{s}$ (360 acre-ft/yr) was measured in Adrian Gap and all the flow infiltrated into the alluvial sediments near the head of the valley. The difference in flow could be due to variable discharge rates from the geothermal powerplant, annual variations in groundwater levels, or both.

${ }^{4}$ http://www.nbmg.unr.edu/geothermal/site.php?sid=Wabuska\%20Hot $\% 20$ Springs, accessed May 7, 2009. 


\section{Wabuska to Little Dam}

Huxel and Harris (1969) estimated a total of 1,400 acre-ft/yr of subsurface inflow through the Walker and Parker Gaps into the alluvial aquifer of the lower Walker River basin. This estimate was revised to 800 acre-ft/yr by Lopes and Allander (2009). Walker River streamflow into the Wabuska-Little Dam reach is measured at the Wabuska gage. The northern Wassuk Range reaches 6,000 ft and the Desert Mountains north of the Walker River reach 6,700 ft with as much as $9 \mathrm{in} / \mathrm{yr}$ of precipitation so little recharge occurs and streams are intermittent. Streamflow out of this reach is measured about 2.5 mi downstream from Weber Reservoir and is the sum of diversions at the Canal No. 1 and Canal No. 2 gages plus discharge at the Little Dam gage. Outflow from the alluvial aquifer occurs by discharge to the Walker River, Weber Reservoir, ET from riparian vegetation, and subsurface flow to the alluvial aquifer downstream from the Little Dam gage.
The Walker River is losing for most of the reach between the Wabuska and Cow Camp gages (pl. 1). At the Willow site, groundwater flows away from the river and down valley (fig. 47A). The river transitions to a stable reach just upstream from the Cow Camp site, indicated by a flat water table at Cow Camp (ig. 47B), groundwater seeps just downstream from Cow Camp (fig. 48), and detection of radon in streamflow upstream from Cow Camp (fig. 49A). Radon quickly degasses from streams, which makes radon a good tracer of groundwater discharge along reaches that are gaining and losing. Radon in groundwater at Walker Gap domestic, Willow site, and Cow Camp site ranged from 630 to $800 \mathrm{pCi} / \mathrm{L}$. Radon was detected in streamflow above the reporting limit at the Wabuska gage, where $2.9 \mathrm{ft}^{3} / \mathrm{s}$ of groundwater discharge was estimated (table 7), and two-thirds of the way between the Wabuska and Cow Camp gages.
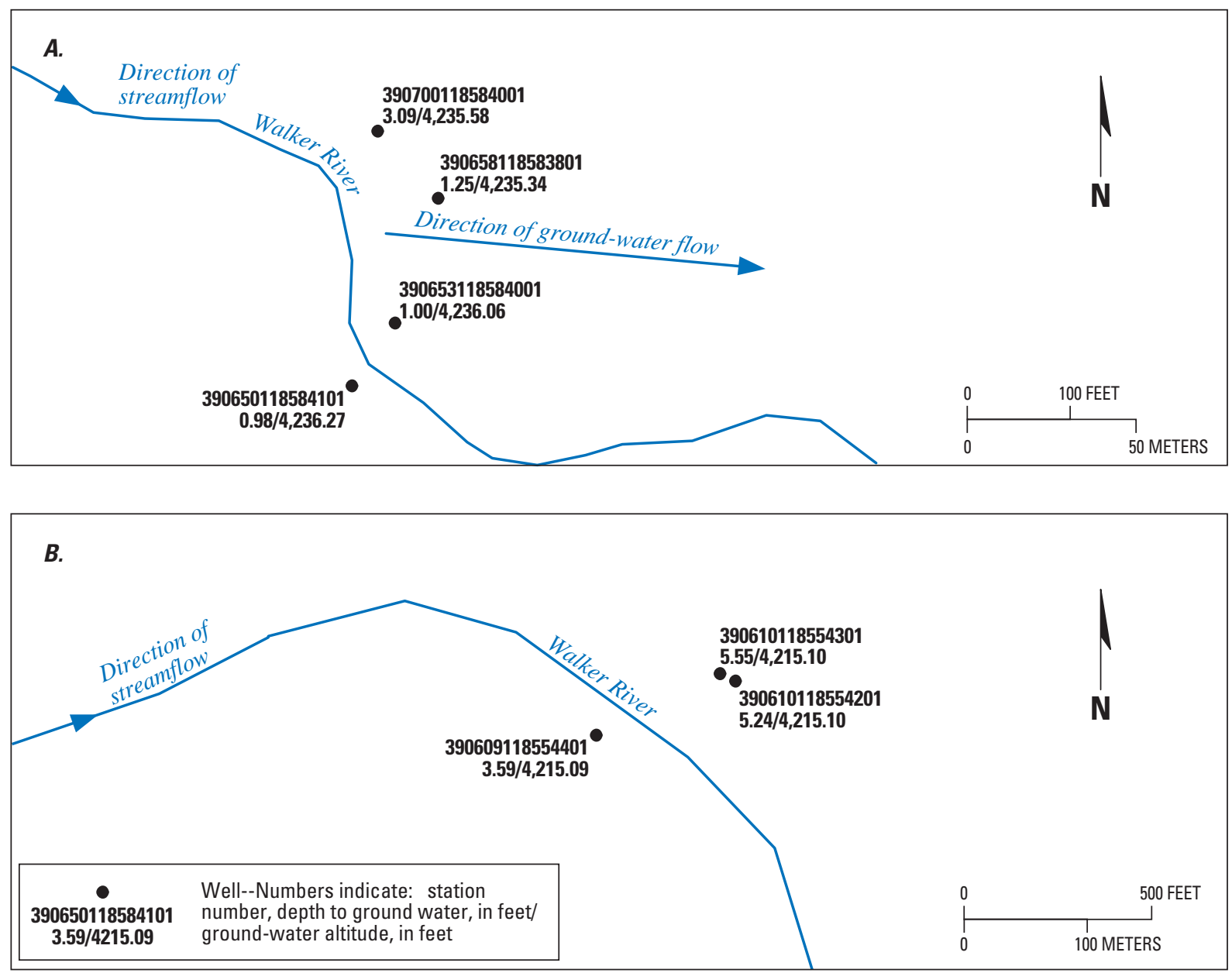

Figure 47. Groundwater levels at the $(A)$ Willow and $(B)$ Cow Camp sites, Walker River basin, Nevada. Water-level measurements were made on December 5, 2006. Daily mean discharge at the Wabuska gaging station (10301500) steadily decreased from 73 to 62 cubic feet per second between December 1 and 5, 2006. Site locations are shown in figure 22. 


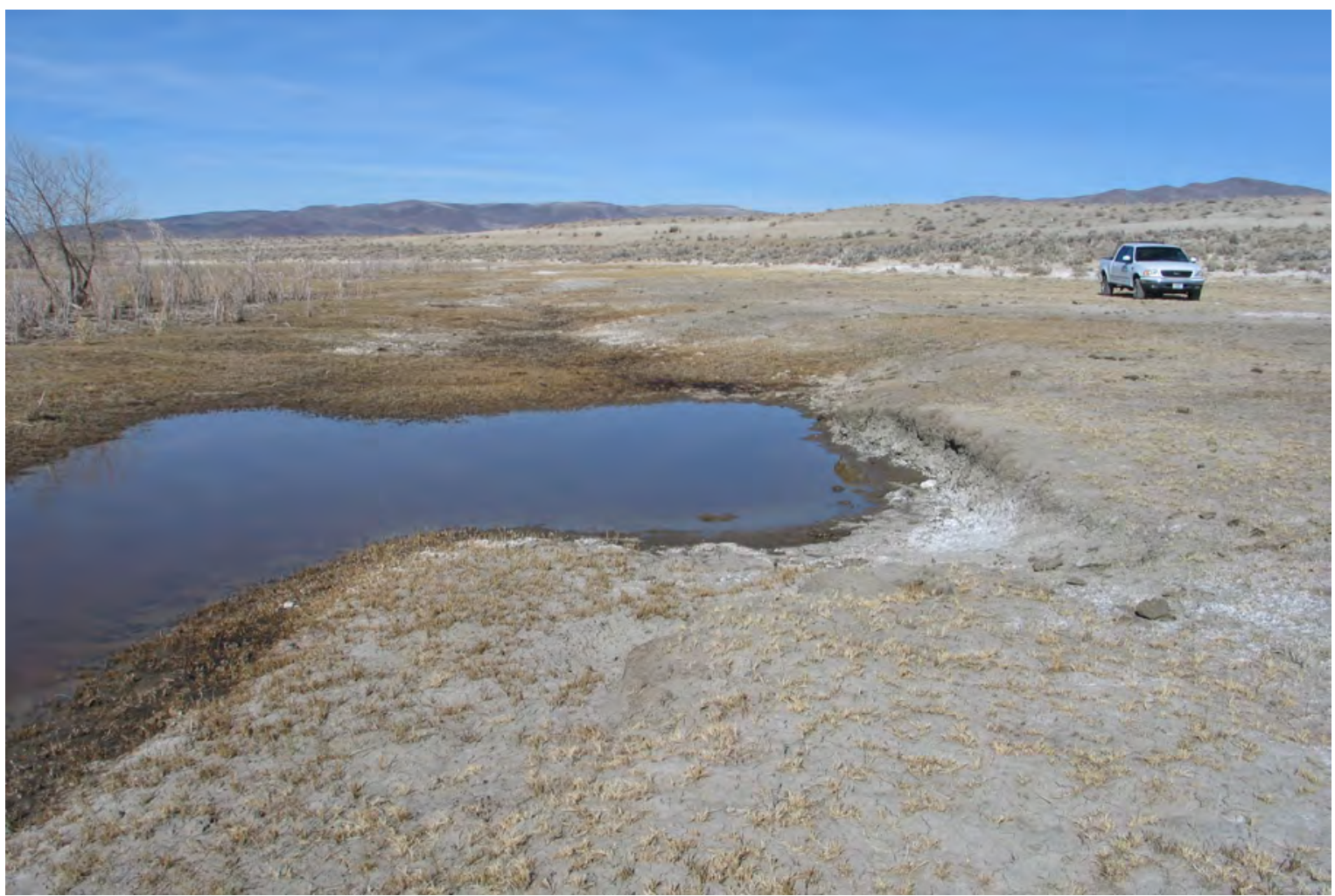

Figure 48. Groundwater seeping into a shallow drainage just downstream from the Cow Camp gaging station (10301600), Walker River basin, Nevada. The gage is in the distance behind the bare vegetation in the upper left of the photograph. (Photograph taken by Thomas J. Lopes, February 6, 2008.)

Infiltration in the reach, just downstream from the Wabuska gage, flows north towards the Wabuska lineament or flows downstream towards Weber Reservoir. The WabuskaLittle Dam reach is bounded by consolidated rock with low hydraulic conductivity. However, the Wabuska lineament could be a pathway for groundwater to flow through the Desert Mountains and into southern Churchill Valley. If this hypothesis is correct, most of the flow along the Wabuska lineament is from northern Mason Valley.

Groundwater altitudes at the Weber well (39030118513401) near Weber Dam typically are higher than the reservoir altitude, indicating groundwater discharges over the length of the reservoir (fig. 50). No groundwater data exist between the Cow Camp gage and Weber Reservoir, but the river must become gaining for the change from a stable reach to a gaining reservoir. During periods when the reservoir altitude rapidly increases, the gradient reverses and water flows from the reservoir into the alluvial aquifer. Most data were collected when storage in Weber Reservoir was maintained below 6,000 acre-ft. Additional data are needed to determine the flow direction when Weber Reservoir is maintained close to its maximum capacity of 10,700 acre-ft. Downstream from Weber Reservoir, water-table contours indicate the Walker River transitions from a gaining to a stable reach near the Little Dam gage.

Even though most of the reach between the Wabuska and Cow Camp gages is losing, the losses seem to be small. In March 2005, low flow was measured at five sites between the Wabuska and Cow Camp gages following 5 years of drought (fig. 49B). An extended drought presumably increases the potential for infiltration, which should be easiest to detect during low flow when loss from infiltration is a large percentage of the discharge. Discharge was steady at $18 \pm$ $1 \mathrm{ft}^{3} / \mathrm{s}$ over the $11 \mathrm{mi}$ reach from the Wabuska gage to the last site located about 2.5 miles upstream from the Cow Camp gage. The $1 \mathrm{ft}^{3} / \mathrm{s}$ range is within measurement error and indicates no appreciable loss. Discharge decreased from 18 to $12 \mathrm{ft}^{3} / \mathrm{s}$ in the $2.5 \mathrm{mi}$ upstream from the Cow Camp gage where the river transitions from a losing to a stable reach. Flow likely bypassed the Cow Camp gage because infiltration of $6 \mathrm{ft}^{3} / \mathrm{s}$ along a stabilizing reach is unlikely. 

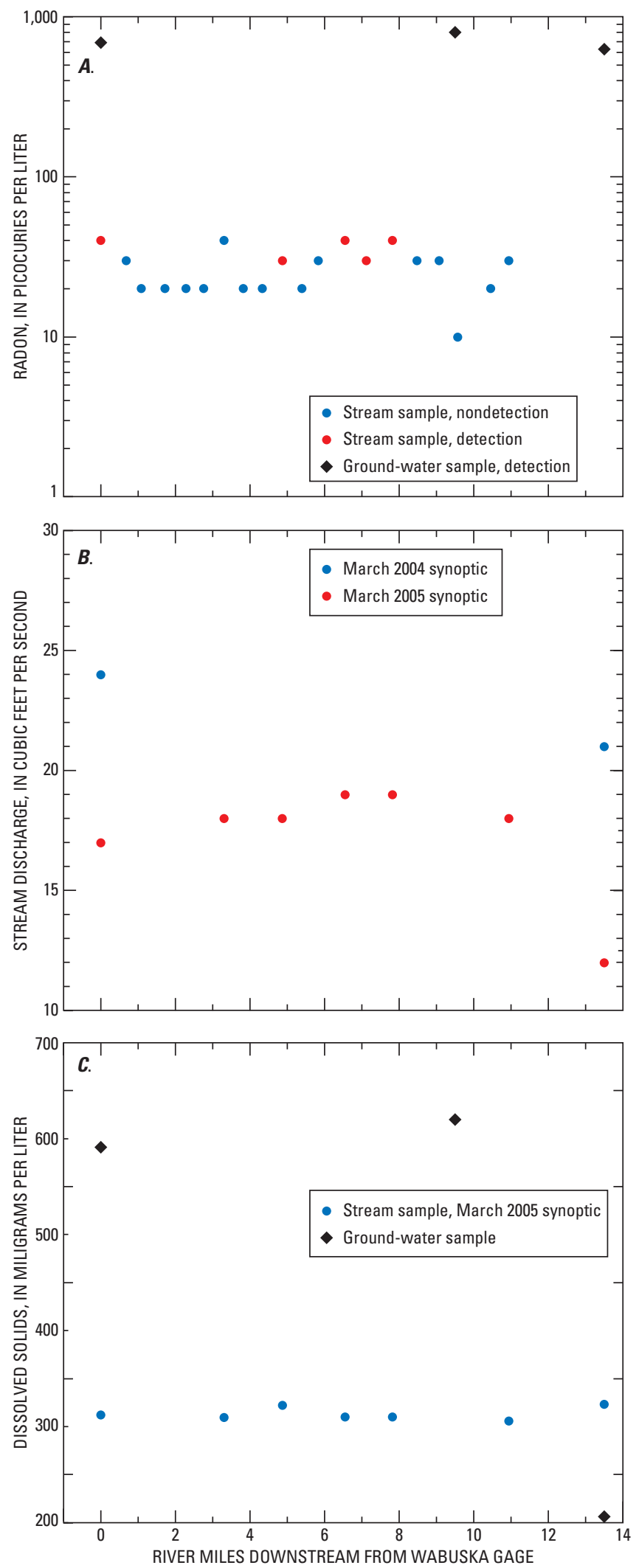

Figure 49. (A) Radon, $(B)$ stream discharge, and $(C)$ dissolved solids in streamflow and groundwater along the Walker River between Wabuska and Cow Camp, Nevada. River miles are downstream from the streamflow-gaging station Walker River near Wabuska, Nevada (10301500).

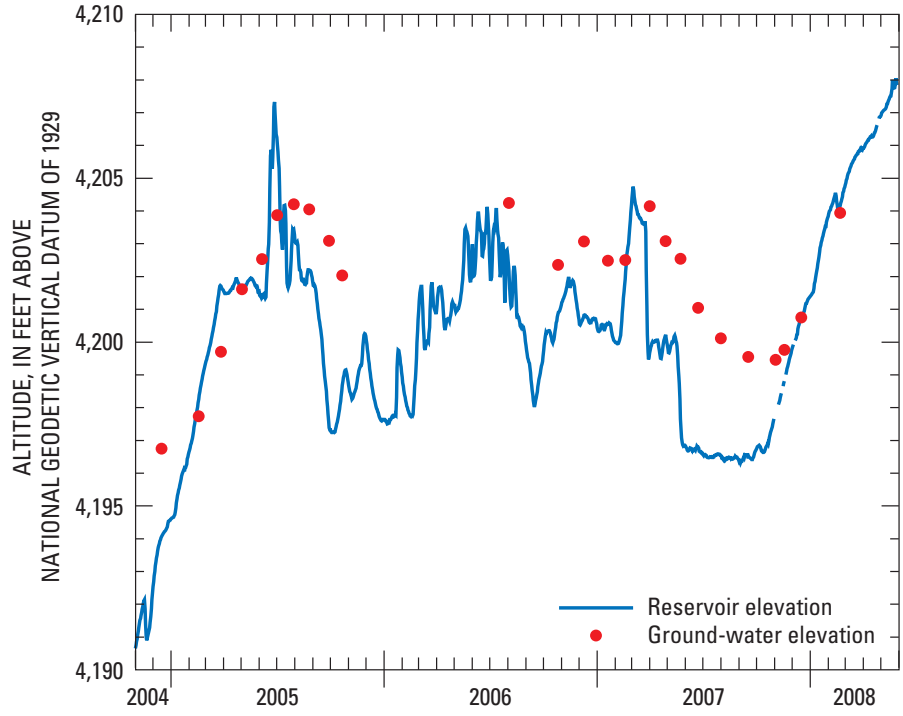

Figure 50. Altitude of groundwater adjacent to Weber Reservoir, Nevada (390303118513401), and reservoir elevation, October 1, 2004, through June 1, 2008.

Lake sediments are thinly interbedded silty clays that occur along both sides of the river between the Wabuska and

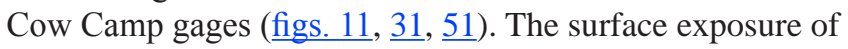
lake sediments extends through the Walker and Parker Gaps into northern Mason Valley where there is a confined aquifer. Silty clays likely underlie the stream channel and minimize infiltration along this reach. This is contrary to Schaefer (1980), who estimated 3,600 acre-ft of stream infiltration in addition to losses from ET. Schaefer's estimate is based on differences in streamflow between the Wabuska and Cow Camp gage between June 1977 and June 1978 and results of a groundwater model. However, the difference most likely is due to streamflow that bypasses the Cow Camp gage.

Radon data indicate groundwater discharge occurs in the lower third of the reach between the Wabuska and Cow Camp gages, but dissolved-solids and major-ion data indicate the amount of discharge is small. Groundwater has about $600 \mathrm{mg} / \mathrm{L}$ of dissolved solids, about twice the concentration of streamflow (fig. 49C). If appreciable, groundwater discharge were occurring between Wabuska and Cow Camp, then a trend of increasing dissolved solids with distance downstream would be expected in streamflow. However, dissolved-solids concentrations fluctuated between $306 \mathrm{mg} / \mathrm{L}$ and $323 \mathrm{mg} / \mathrm{L}$ with no consistent trend.

Ratios of major ions are similar in streamflow from the West and East Forks of the Walker River and ratios do not change appreciably to the Cow Camp gage (fig. 52). The major-ion chemistry of most groundwater in this reach is distinct from streamflow and should change ratios in streamflow, if appreciable groundwater discharge is occurring. 


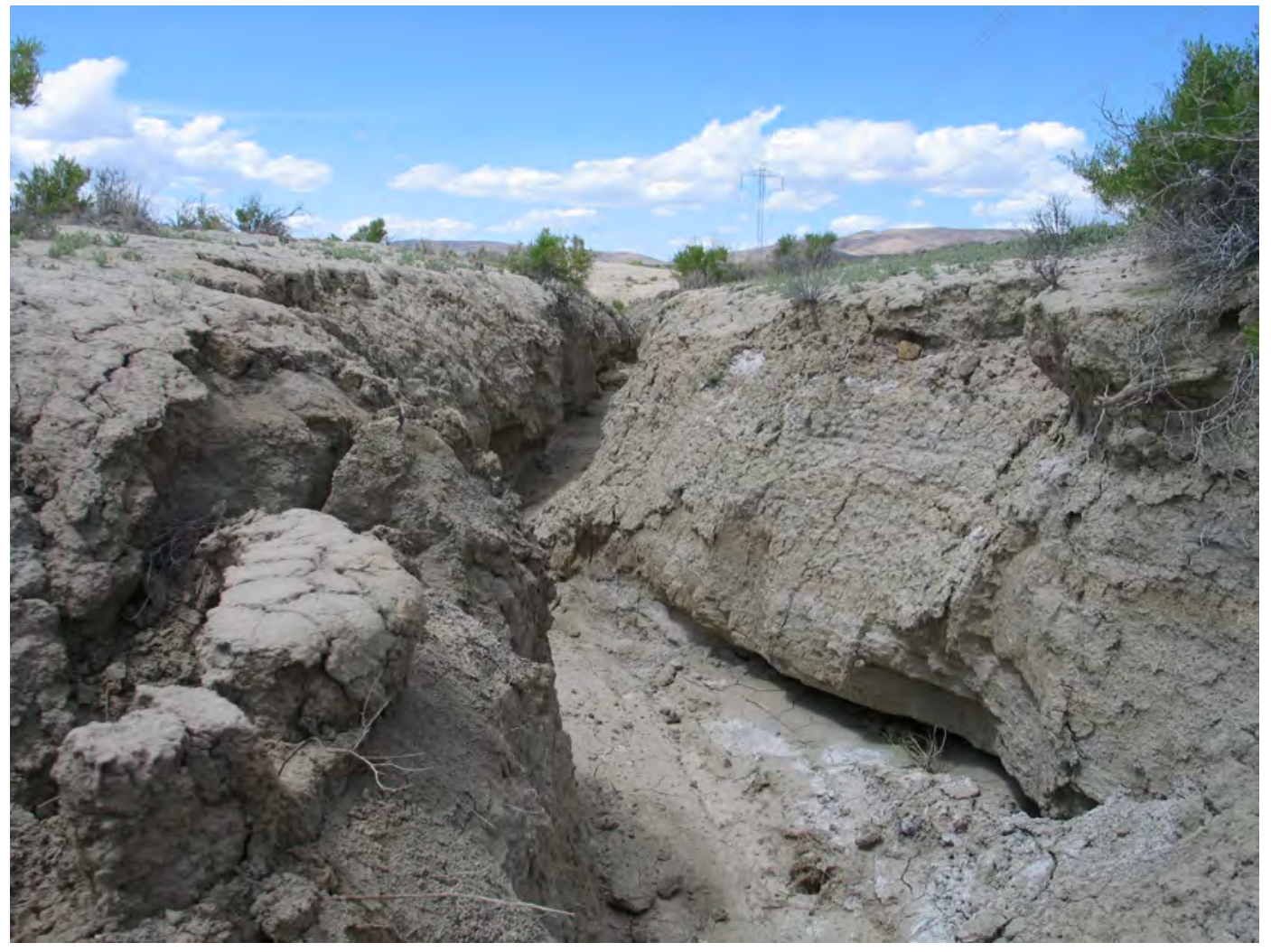

Figure 51. Lake sediments exposed in a drainage about 0.5 mile south of the Walker River near Parker Butte, Nevada. (Photograph taken by Thomas J. Lopes, June 3, 2008.)

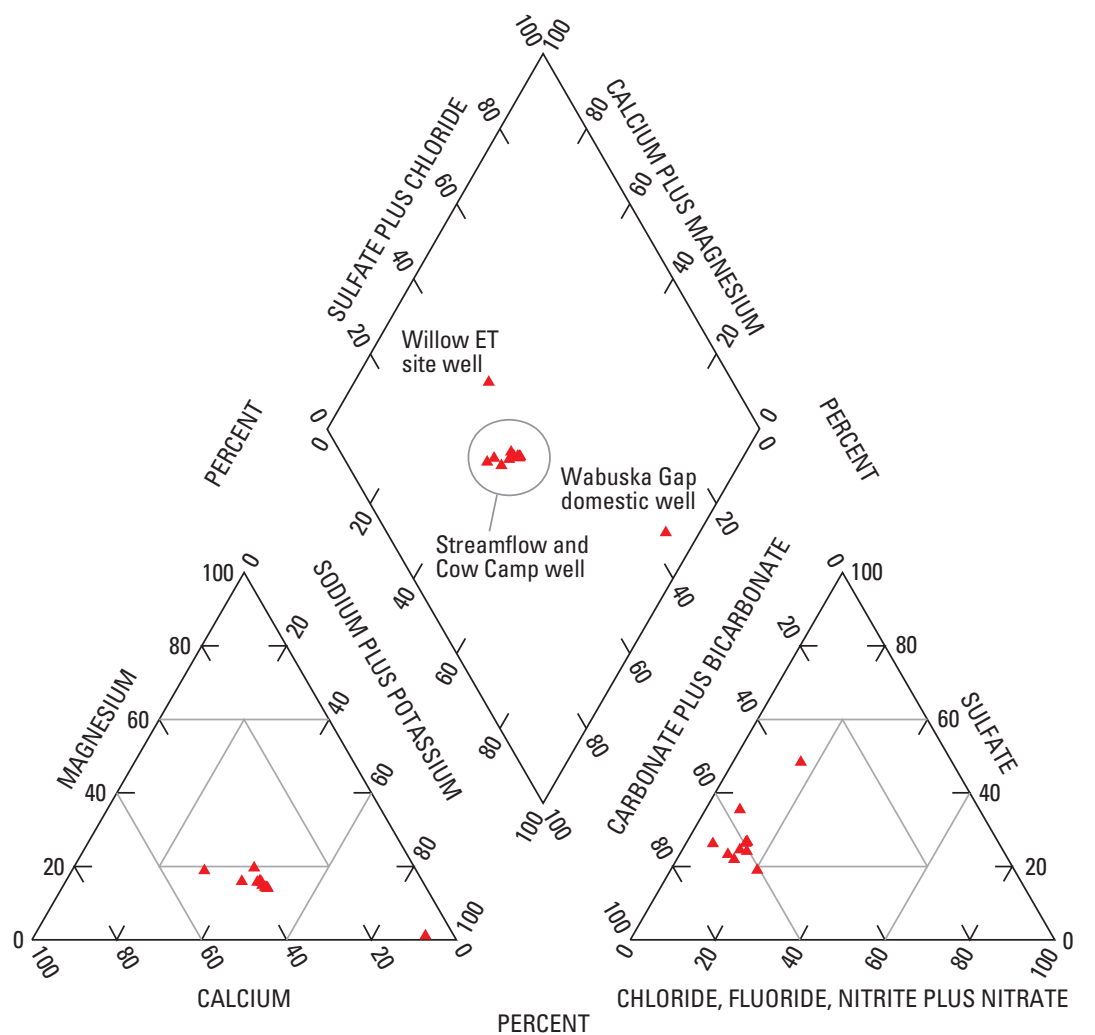

Figure 52. Proportions of major ions in groundwater and streamflow from the Wabuska gaging station (10301500) to the Cow Camp gaging station (10301600), Walker River basin, Nevada. 
Basalt in Walker Gap mostly is sodium and sulfate and alluvium at the Willow site has a greater proportion of calcium compared to streamflow. Groundwater at the Cow Camp site was sampled soon after the 2006 runoff and has the same major-ion ratios as streamflow. The constant ratio of major ions in streamflow indicates little groundwater discharge upstream from the Cow Camp gage.

Although measurements indicate little infiltration or groundwater discharge between the Wabuska and Cow Camp gage, stream losses occur from ET by riparian vegetation. Discharge at the Wabuska gage never exceeded $200 \mathrm{ft}^{3} / \mathrm{s}$ and usually was less than $80 \mathrm{ft}^{3} / \mathrm{s}$ during the drought from 2000 through 2004 (fig. 53A). Differences in mean daily discharge between the Wabuska and Cow Camp gages have an annual cycle that starts increasing in April, reaches a maximum in July or early August, then decreases to a minimum in late October and stays low from November through March (fig. 53B $)$. This cycle closely resembles ET rates for willow in this reach (Allander and others, 2009), indicating that riparian vegetation is obtaining water from the river. Accurately estimating riparian ET losses using streamflow data is not possible due to streamflow bypassing the Cow Camp gage.

At the Willow site 5 mi upstream from Weber Reservoir, depth to water typically was less than $4 \mathrm{ft}$ except during high flows when groundwater was just below land surface (fig. 54A). Groundwater levels respond almost instantly to changes in streamflow, indicating a good hydraulic connection between the river and adjacent aquifer. Groundwater temperature ranges from 45 to $68^{\circ} \mathrm{F}$ and has an annual cycle that does not seem to be affected by the timing or magnitude
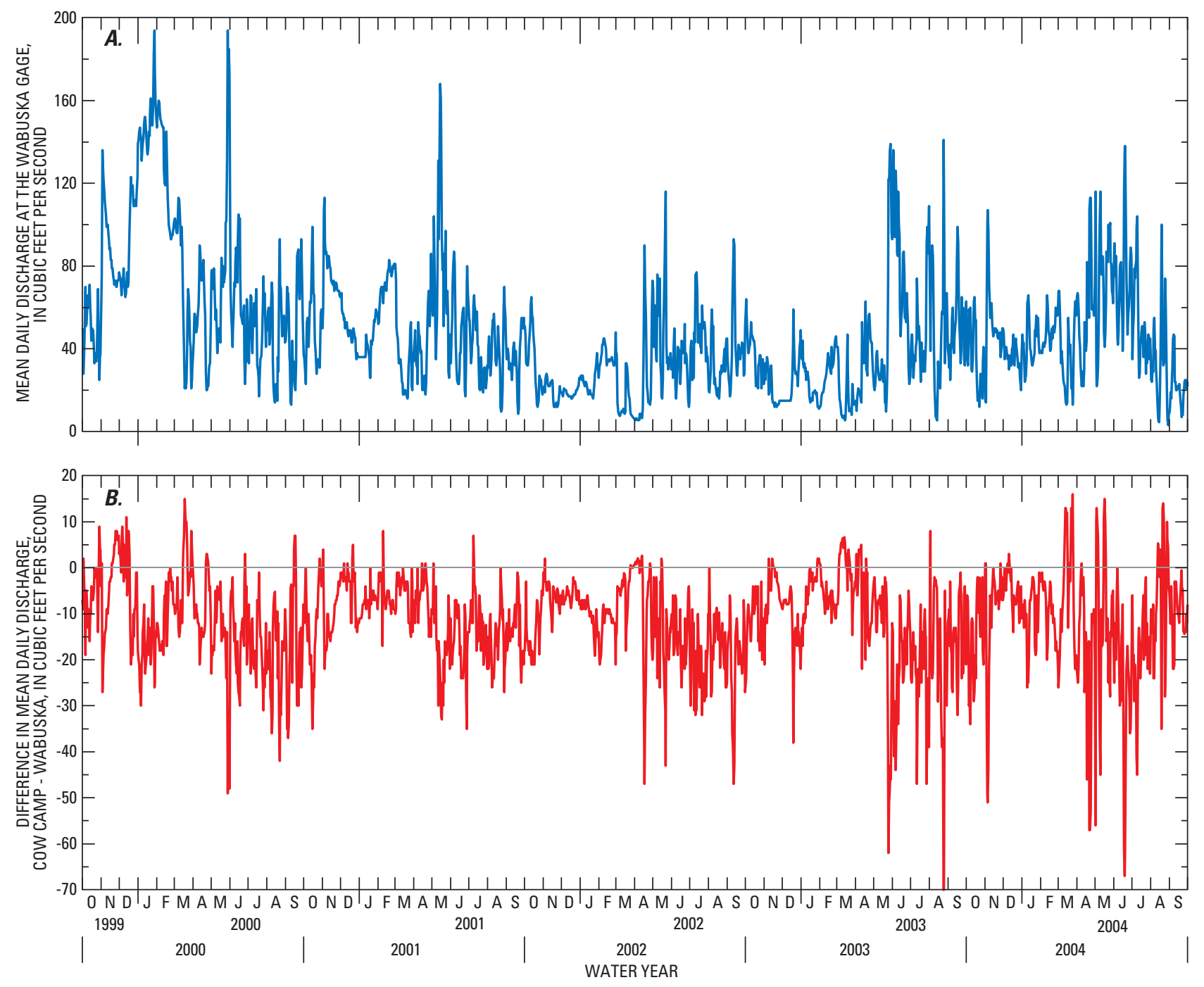

Figure 53. Mean daily discharge at the $(A)$ Wabuska gaging station (10301500) and $(B)$ difference in mean daily discharge between the Cow Camp (10301600) and Wabuska gaging stations, Walker River basin, Nevada, October 1, 1999, through September 30, 2004. Travel time between the gaging stations was accounted for by subtracting mean daily discharge at Cow Camp gage for the following day from the mean daily discharge at Wabuska gage. 

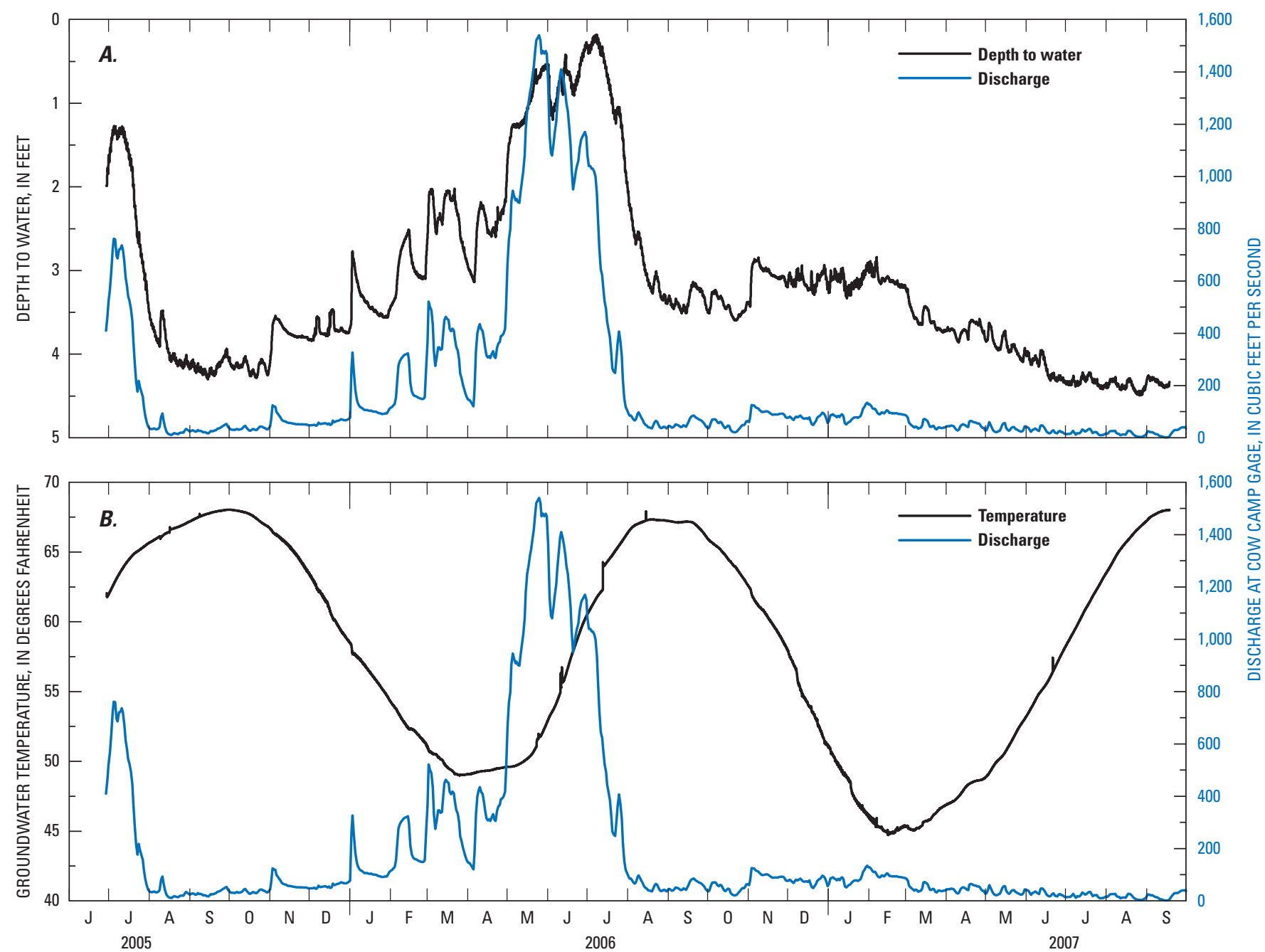

Figure 54. ( $A)$ Depth to water and $(B)$ groundwater temperature at the Willow site and stream discharge at the Cow Camp gaging station (10301600), Walker River basin, Nevada.

of streamflow (fig. 54B). The minimum temperature is reached in late February to late March and the maximum temperature is reached in late August to early October. In comparison, the mean daily minimum air temperature at the Wabuska 5E weather station occurs around January 1 and the maximum air temperature occurs around August $1^{5}$, indicating a 2-month lag for air temperatures to affect shallow groundwater temperatures.

\section{Little Dam to Lateral 2-A}

Water-level contours indicate the Walker River changes from stable near the Little Dam gage to losing 2-3 river mi downstream from the gage (pl. 1). The river is losing along 8 river mi, indicated by horizontal gradients away from the river and a downward vertical gradient at the Lateral 2-A site (fig. 55). Schurz is roughly at the midpoint of the losing reach.
Most irrigated fields around Schurz are adjacent to the losing reach. Canal No. 1 distributes water west of the river and is lined with concrete along its entire length. Canal No. 2 distributes water east of the river and is lined with concrete to the intersection of Lake Pasture Road and Heartfalls Lane about $2.5 \mathrm{mi}$ southeast of Schurz where it becomes unlined for the remainder of its length. Diverted streamflow infiltrates through unlined portions of the canal, unlined laterals that distribute water from canals, and flood-irrigated fields.

The difference in discharge between the Little Dam and Lateral 2-A gages is due to infiltration and riparian ET along this losing reach of the Walker River. Differences in the accumulated volume of discharge were calculated for water years 2005-08, which represent a wide range in flow conditions. Streamflow at the Wabuska gage was about 20 percent of the 1971-2000 normal in 2008, 30 percent in 2007, 100 percent in 2005, and 200 percent in 2006 (fig. 25).

${ }^{5}$ http://www.wrcc.dri.edu/summary/Climsmnv.html, accessed May 7, 2009. 


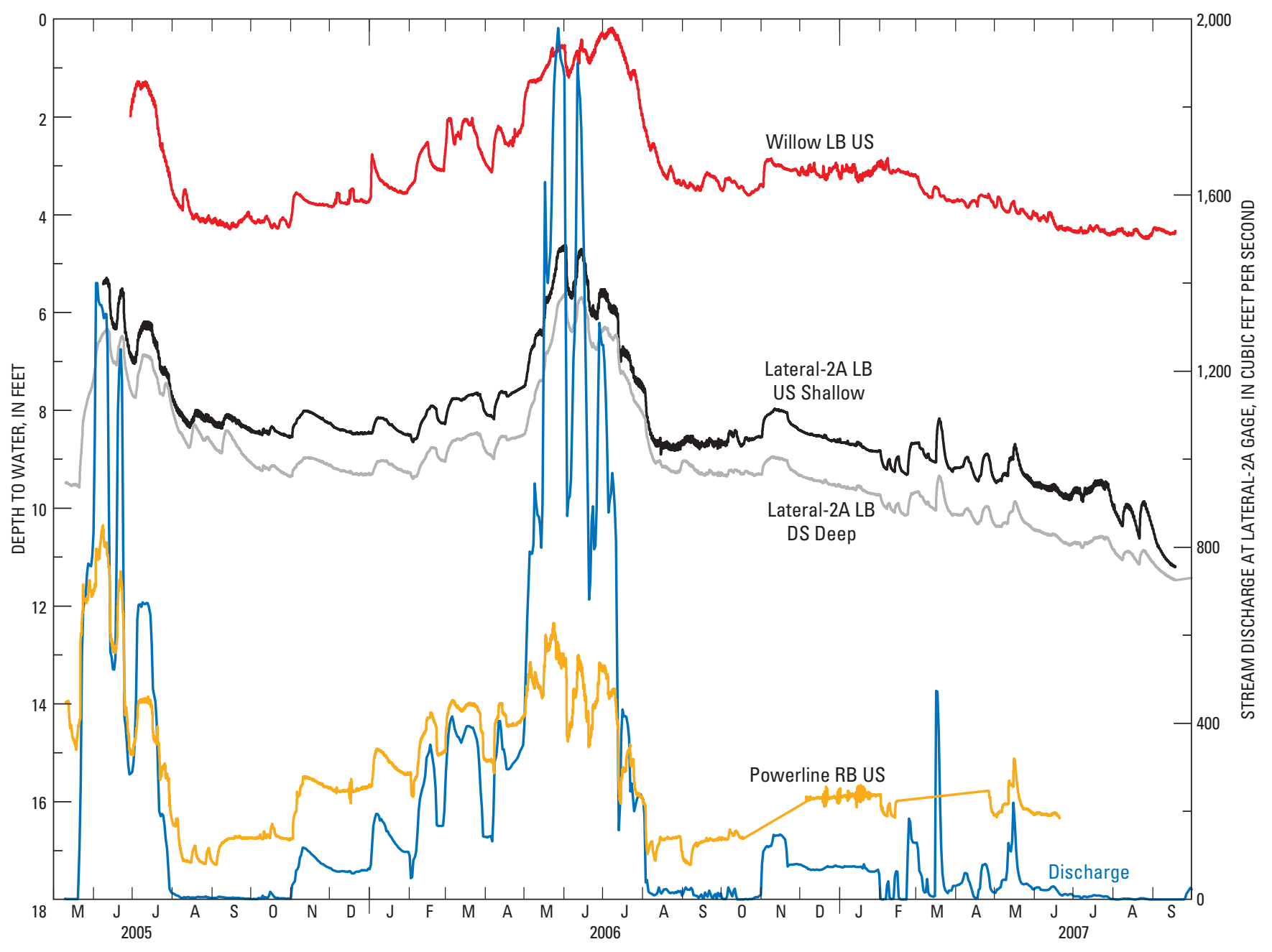

Figure 55. Depth to water at the Willow, Lateral 2-A, and Powerline sites and stream discharge at the Lateral 2-A gaging station (10302002), Walker River basin, Nevada, May 1, 2005, through September 30, 2007.

Stream losses indicate the Little Dam-Lateral 2-A reach has a large infiltration capacity compared to the WabuskaLittle Dam and Lateral 2-A-Walker Lake reaches. About 5,700 acre-ft of streamflow infiltrated along the Little DamLateral 2-A reach during the 2005 spring runoff (fig. 56). Some infiltration went into bank storage and discharged back into the river following peak discharge in June 2005. Total stream loss along Little Dam-Lateral 2-A reach was about 3,000 acre-ft during 2005.

Losses increased during 2006 when there was almost continual flow through the reach. Some infiltration went into bank storage and discharged back into the river following the 2006 runoff, but bank-storage discharge was less than 2005 . Total stream loss during 2006 was 12,600 acre-ft, which may have filled bank and aquifer storage. The river flowed with little loss from October through April 2007 even though there was almost continual flow through the reach. Stream losses then increased by 2,100 acre-ft from May through
September 2007, which partly was due to riparian ET. Total loss was 3,000 acre-ft during 2007 and 3,900 during 2008.

Huffman and Carpenter, Inc. (2007) estimated stream losses along the Little Dam-Lateral 2-A and Lateral 2-AWalker Lake reaches. Instantaneous discharge at each site was measured using USGS procedures on 1 day of the week from March 14 through September 27, 2007. Instantaneous discharge was assumed to represent daily mean discharge, and daily mean discharge between measurements was estimated by linear interpolation. Discharge volumes were calculated for each day and summed.

Comparison of discharge measurements with mean daily discharge at the Lateral 2-A gage indicates some peak discharges and sudden drops in discharge were missed, but in general estimates seem reasonable. Total discharge volume estimated at the Little Dam gage was within 10 percent of the volume calculated using USGS data and within 15 percent at the Lateral 2-A gage. Total stream loss between the gages 


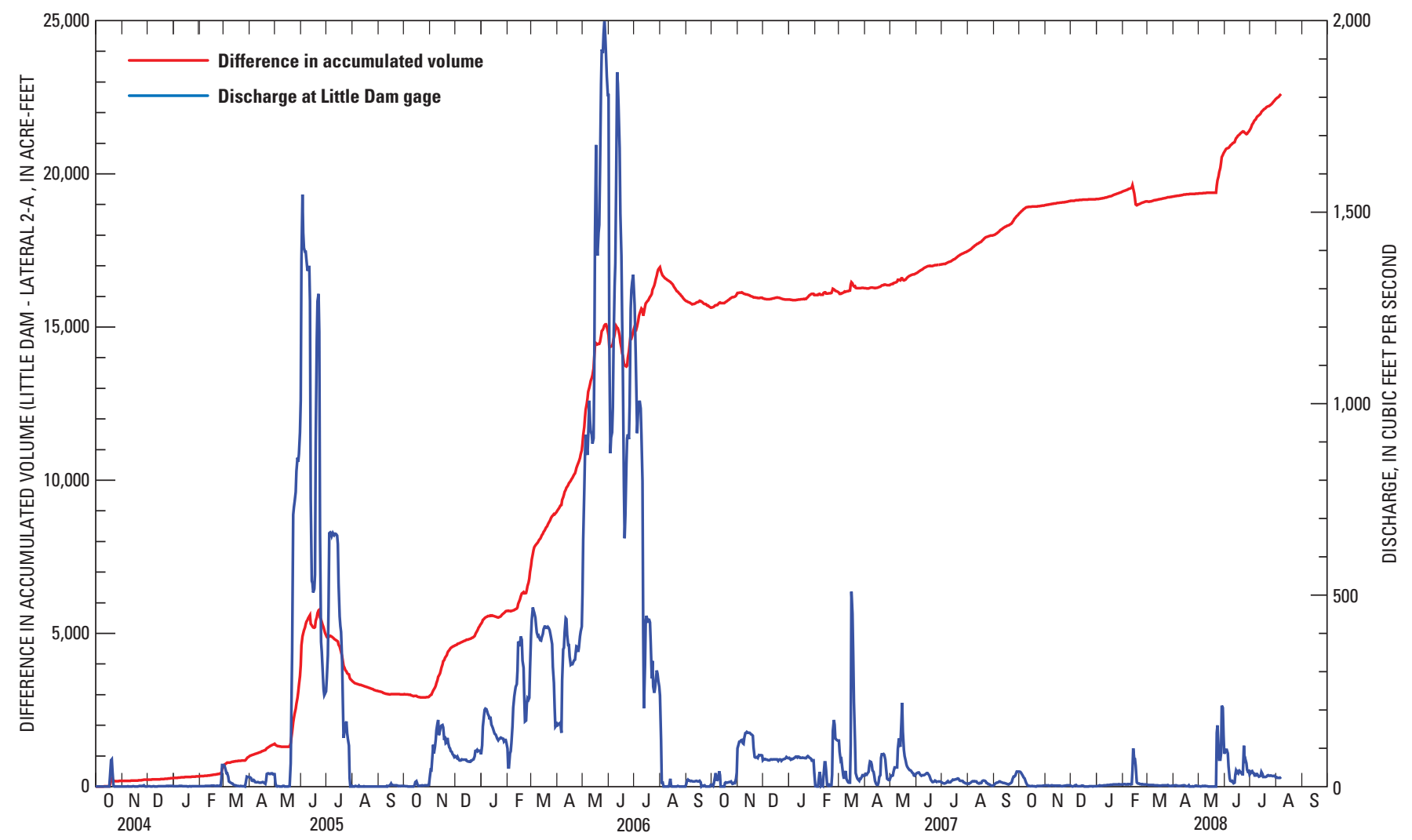

Figure 56. Streamflow at Walker River above Little Dam near Schurz, Nevada (10301745), and difference in accumulated volume of streamflow between Little Dam and Lateral 2-A (10302002) gaging stations, Walker River basin, Nevada, October 1, 2004, through September 30, 2008.

was estimated to be 2,675 acre-ft compared with 2,412 acre-ft using USGS data. However, the timing of the stream loss was different. During March and April, Huffman and Carpenter, Inc. (2007) estimated a loss of 792 acre-ft versus 186 acre-ft using USGS data. During August and September, Huffman and Carpenter, Inc. (2007) estimated a loss of 667 acre-ft versus 1,124 acre-ft using USGS data.

Measured stream loss along the Little Dam-Lateral 2-A reach ranged from 3,000 to $12,600 \mathrm{acre}-\mathrm{ft} / \mathrm{yr}$. Mean annual stream loss is difficult to estimate because only 4 years of data exist and losses depend on antecedent years. How antecedent conditions affect losses is unclear. Presumably, maximum loss would occur during 2005 after a 5-year drought (2000-04) but that was not the case. Mean annual infiltration is about 6,000 acre-ft assuming the mean of the 4 years of data approximates the true mean. This estimate should be re-evaluated when more data are available.

In addition to stream infiltration, induced recharge occurs along unlined canals, laterals, and irrigated fields around Schurz. Recharge has created a groundwater divide along the Walker River that extends southeast along unlined portions of Canal No. 2 (pl. 1). The divide separates groundwater that flows south towards Walker Lake from groundwater that flows east towards Double Spring and out of the Walker River basin. The Schurz NE monitoring wells indicate a small upward vertical component to the eastward flow (fig. 57A) that becomes large enough for groundwater to flow from the Double Spring well.

Subsurface flow through Double Spring was first reported by Schaefer (1980), who hypothesized that groundwater flows out of the Schurz subarea to Rawhide Flats (hydrographic area 123). However, groundwater altitudes in southern Rawhide Flats (14N/31E-21B2, 3,973 ft; Schaefer, 1980) and the eastern Schurz subarea (385841118320601, 3,942 ft; $385430118290401,3,940 \mathrm{ft}$ ) indicate a groundwater divide separates the two hydrographic areas. Additional data are needed to determine groundwater-flow directions east of Double Spring and where subsurface flow discharges.

Groundwater from the Double Spring well has isotopic values similar to streamflow and groundwater around Schurz and plots along the Walker-Wassuk evaporation line (ig. 46). Groundwater north and northeast of Schurz flows east and is closer to Double Spring than the river but isotopic data plot along the Gillis-Calico evaporation line. Virtually all flow from the Double Spring well originates from the Walker River and is not local recharge or Pleistocene-age groundwater. 


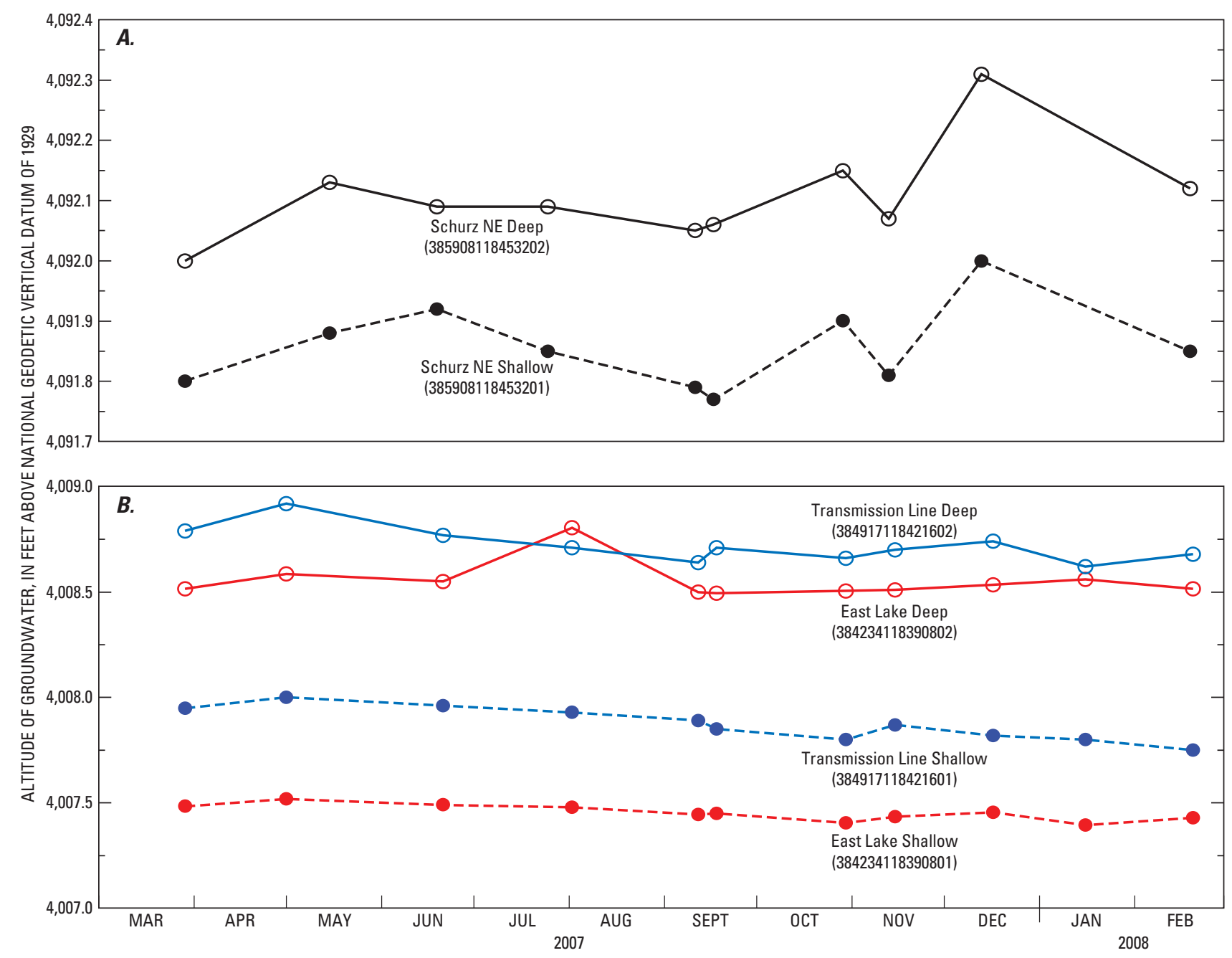

Figure 57. Groundwater altitudes at the $(A)$ Schurz NE wells and $(B)$ Transmission Line and East Lake wells, Walker River basin, Nevada, March 1, 2007, through March 1, 2008.

\section{Lateral 2-A to Walker Lake}

Water-level contours indicate the river changes from losing to gaining about midway between the Lateral 2-A and Powerline sites and remains gaining along 16 river $\mathrm{mi}$ to Walker Lake. The 2-ft upward vertical gradients at the Transmission Line (384917118421601, 384917118421602) and East Lake sites (384234118390801, 384234118390802) also indicate groundwater discharge around Walker Lake (fig. 57B).

Although most of this reach is gaining, stream losses were measured between the Lateral 2-A gage and Walker Lake. From 2000 to May 2005, little streamflow was measured at the Lateral 2-A gage and Walker Lake declined about $21 \mathrm{ft}$. Groundwater levels likely declined and the unsaturated zone would have been near its maximum thickness. The maximum amount of infiltration possible between the Lateral 2-A gage and Walker Lake likely occurred during the 2005 spring runoff when streamflow at the Wabuska gage was nearly equal to the 1971-2000 normal (fig. 25).

Spring runoff reached the Lateral 2-A gage on May 21, 2005 (fig. 58). The difference in accumulated volumes between the Lateral 2-A and near Mouth gages reached a maximum of 11,000 acre-ft on July 5, 2005. A large amount of water quickly infiltrated and went into bank storage. As flow subsided, the difference between the two gages decreased to 8,700 acre-ft on July 21,2005 , due to bank storage discharging back into the channel. Bank storage continued to discharge and by December 2005 the difference in accumulated volumes was 8,000 acre-ft.

From January to March 2006, discharge at the Lateral 2-A gage was from 60 to $350 \mathrm{ft}^{3} / \mathrm{s}$ yet the difference in accumulated volumes remained about the same. Bank and aquifer storage had reached a maximum and the river flowed 


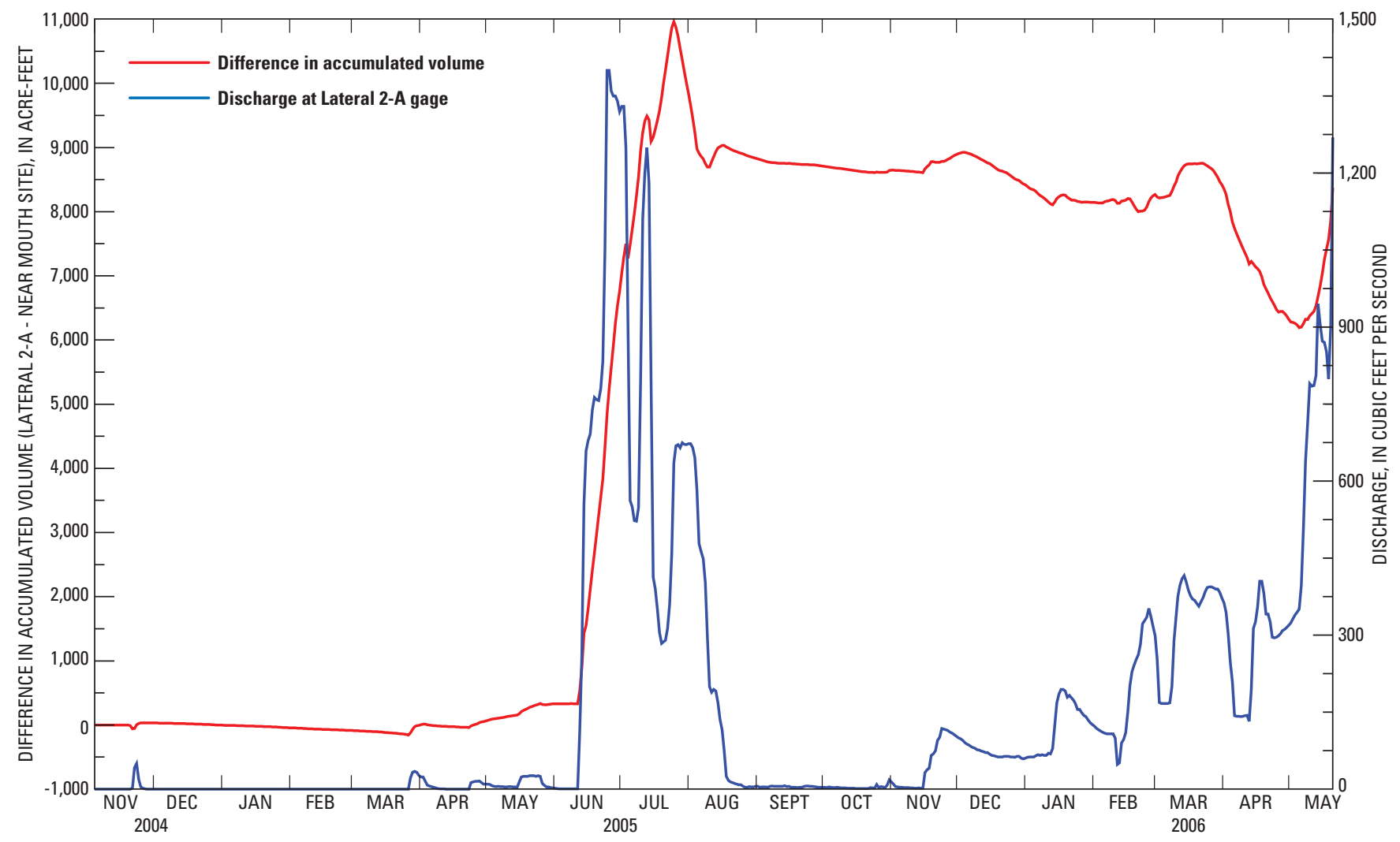

Figure 58. Difference in accumulated volume of streamflow between the Lateral 2-A (10302002) and the near Mouth (10302025) gaging stations and stream discharge at the Lateral 2-A gage, Walker River basin, Nevada, 0ctober 1, 2004, through May 16, 2006.

to the lake without appreciable losses. Discharge at the Lateral 2-A gage was about $400 \mathrm{ft}^{3} / \mathrm{s}$ during most of March 2006. Following this event, the difference in accumulated volume between the two gages decreased to 6,200 acre-ft. The decrease seems to be due to down cutting of the channel. The Walker River downstream from the Lateral 2-A gage has been down cutting as the lake has receded since the late 1800s (Adams, 2007). Down cutting the stream channel below the saturated zone would cause groundwater to quickly drain into the river.

Huffman and Carpenter, Inc. (2007) estimated 1,129 acre-ft of stream loss in the Lateral 2-A-Walker Lake reach from March 14 to September 27, 2007. Most of the loss was estimated during March and April. Monthly discharge volumes at the Lateral 2-A gage were about the same from March through May, but essentially no loss occurred during May. Aquifer storage apparently had reached a maximum even though the reach had a small amount of flow since August 2006. Allander and others (2009) estimated 2,800 acre-ft/yr of net ET by saltcedar and riparian vegetation along this reach, which is assumed to be the minimum stream loss except when less discharge flows into the reach.

Down cutting seems to explain certain changes in groundwater levels at the Powerline gage. Depth to water at the Powerline gage was about $14 \mathrm{ft}$ prior to the 2005 spring runoff (fig. 59). Depth to groundwater decreased during runoff due to the high river stage, then increased to $17 \mathrm{ft}$ after flow ceased. The 3-ft increase in depth to water likely was due to down cutting of the channel and drainage of the aquifer. Depth to groundwater steadily decreased to about $14 \mathrm{ft}$ from August 2005 to May 2006. Sediments deposited during low to moderate flows may have reduced aquifer drainage. Similar changes in depth to groundwater occurred following the 2006 spring runoff. 


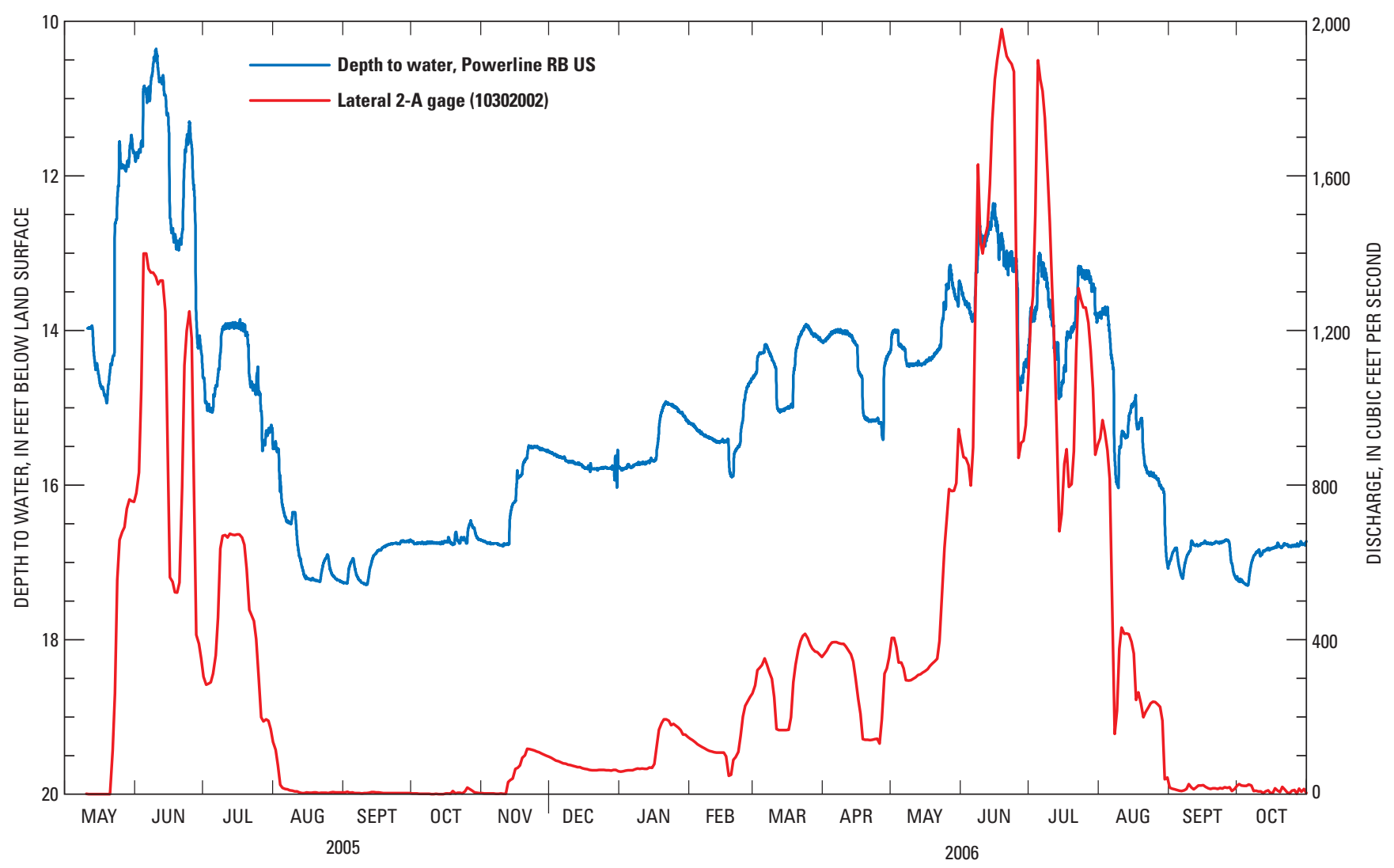

Figure 59. Depth to water at the Powerline site and stream discharge at the Lateral 2-A (10302002) gaging station, Walker River basin, Nevada, May 1, 2005, through October 1, 2006.

\section{Hawthorne Area}

Water-level contours in the Hawthorne area indicate recharge occurs along the southern Wassuk and Gillis Ranges, Anchorite Hills, and Excelsior Mountains and flows north towards Walker Lake. All streams that flow over alluvial sediments are intermittent in the Hawthorne area and streamflow rarely occurs distant from the mountain fronts. Streamflow is disconnected from the alluvial-aquifer system and quickly infiltrates through permeable stream channels and soils (fig. 29). Springs discharge from the alluvial aquifer just south of Walker Lake where there is a riparian zone of Russian olive, cottonwood, and grass (fig. 60).

\section{Walker Lake}

Water-level contours and upward vertical gradients indicate Walker Lake is the final discharge point for groundwater and streams in the lower Walker River basin (pl. 1, fig. 57B). Alluvial aquifers discharge into all sides of the lake. Alluvial aquifers north and south of Walker Lake were discussed previously. The alluvial aquifer west of Walker Lake is a 0.5 - to 2-mi wide band of steep alluvial fans along the eastern flank of the Wassuk Range. The alluvial aquifer east of the lake is a 1- to 3-mi wide band of less steep alluvial fans along the western flank of the Gillis Range.

Prior to diverting runoff to the Army Depot, most recharge along the Wassuk Range was from snowmelt that ran off steep drainage basins and infiltrated through the alluvial fans. Currently (2008), most runoff from Cottonwood Creek to Cat Creek is diverted before reaching alluvial sediments. Diversions have reduced the amount of recharge and may have changed the predominant recharge mechanism. Most recharge could be occurring by infiltration into fractured consolidated rock that eventually discharges through the subsurface into alluvial sediments. Sometimes called hidden recharge, this also could be the mechanism for recharge along the Gillis Range. Streamflow in Wildhorse Canyon was seldom recorded from 2005 through 2007 and all discharge was less than $2 \mathrm{ft}^{3} / \mathrm{s}$ indicating runoff usually does not reach alluvial sediments. 


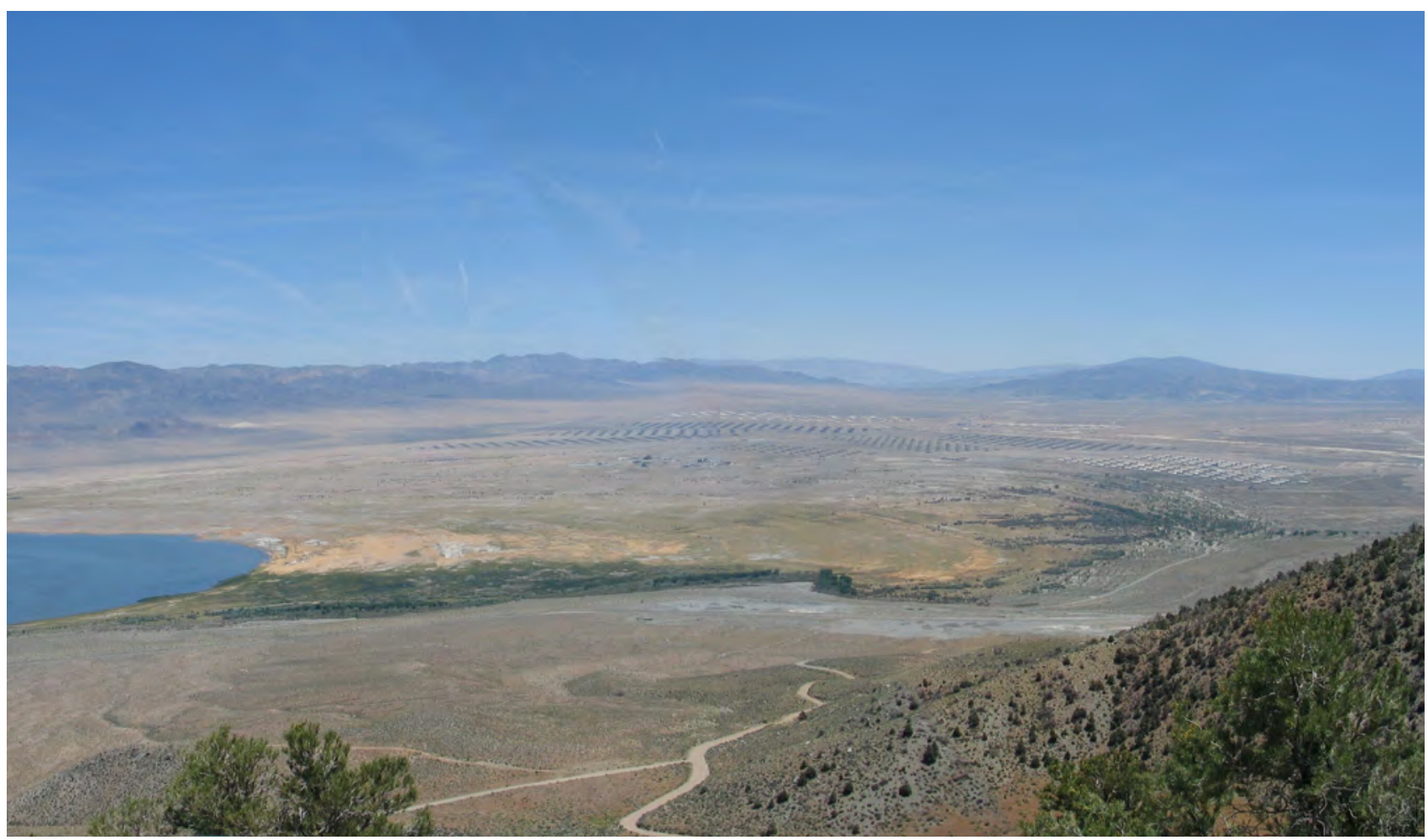

Figure 60. View from the Wassuk Range looking southeast at the riparian area at the southern end of Walker Lake, Nevada. (Photograph taken by Kip K. Allander, June 1, 2008.)

The Walker River and groundwater north and west of Walker Lake have $\delta^{2} \mathrm{H}$ values of $-100 \%$ or less and $\delta^{18} \mathrm{O}$ values of $-12 \%$ or less (fig. 61A). Shallow (less than $3 \mathrm{ft}$ ) pore-water, lake-bottom, and mid-depth data collected from Walker Lake (fig. 45) plot along the Walker-Wassuk evaporation line, indicating the river and groundwater are the main sources of water to the lake. Deep (6-215 ft) pore water collected by Benson (1988) and groundwater east and northeast of Walker Lake are relatively light, do not plot along the Walker-Wassuk evaporation line, and are not significant sources of water.

At mid-depth throughout Walker Lake, $\delta^{2} \mathrm{H}$ averaged $-27.0 \%$ with a standard deviation of $0.8 \%$ and $\delta^{18} \mathrm{O}$ averaged $0.9 \%$ with a standard deviation of $0.1 \%$. The Wilcoxon signrank test indicated lake-bottom water is significantly lighter than mid-depth water (fig. 61B $)$. At lake bottom, $\delta^{2} \mathrm{H}$ averaged $-27.8 \%$ with a standard deviation of $1.2 \%$ and $\delta^{18} \mathrm{O}$ averaged $0.8 \%$ with a standard deviation of $0.2 \%$. Shallow pore water is significantly lighter than lake-bottom and mid-depth water. $\delta^{2} \mathrm{H}$ averaged $-33.3 \%$ with a standard deviation of $10.1 \%$ and $\delta^{18} \mathrm{O}$ averaged $0.0 \%$ with a standard deviation of $1.7 \%$. The large standard deviation for shallow pore water is due to two samples that plot about mid-way along the WalkerWassuk evaporation line (fig. 61A).

\footnotetext{
${ }^{6}$ http://wdr.water.usgs.gov/wy2006/pdfs/384443118430901.2006.pdf
}

Walker Lake thermally stratifies during April and May, turns over in late October, and remains unstratified through March (Cooper and Koch, 1984; Horne and others, 1994; Allander and others, 2009). Uniform water temperatures to a depth of $100 \mathrm{ft}$ indicate turn over mixes the lake from topto-bottom (Horne and others, 1994). The thermocline that separates the epilimnion from the hypolimnion is from 43 to $50 \mathrm{ft}$ deep during August through October (Rush, 1970; Lopes and Smith, 2007) and was about $40 \mathrm{ft}$ deep on August 1, $2006^{6}$. Temperature profiles were not done during July and August 2007 when cores and water-column samples were collected.

Isotopic stratification in the water column is due mainly to evaporation during the 9-10 months since turn over during autumn 2006 (Hostetler and Benson, 1994). Evaporation concentrates ${ }^{2} \mathrm{H}$ and ${ }^{18} \mathrm{O}$ near the water surface. All mid-depth samples were collected from the epilimnion. The lack of a significant Spearman rank correlation between $\delta^{2} \mathrm{H}$ at middepth and mid-lake depth (2.5 to $38 \mathrm{ft}$ ) indicates wind mixes isotopes concentrated at the surface throughout the epilimnion. $\delta^{2} \mathrm{H}$ at lake bottom and lake depth in the hypolimnion (greater than $40 \mathrm{ft}$ ) also were not significantly correlated, but there was a significant Spearman rank correlation $(-0.83)$ between $\delta^{2} \mathrm{H}$ at lake bottom and lake depth for all samples. The strong correlation for all lake-bottom samples is because 14 of the 28 cores sites were in from 5 to $39 \mathrm{ft}$ of water. 

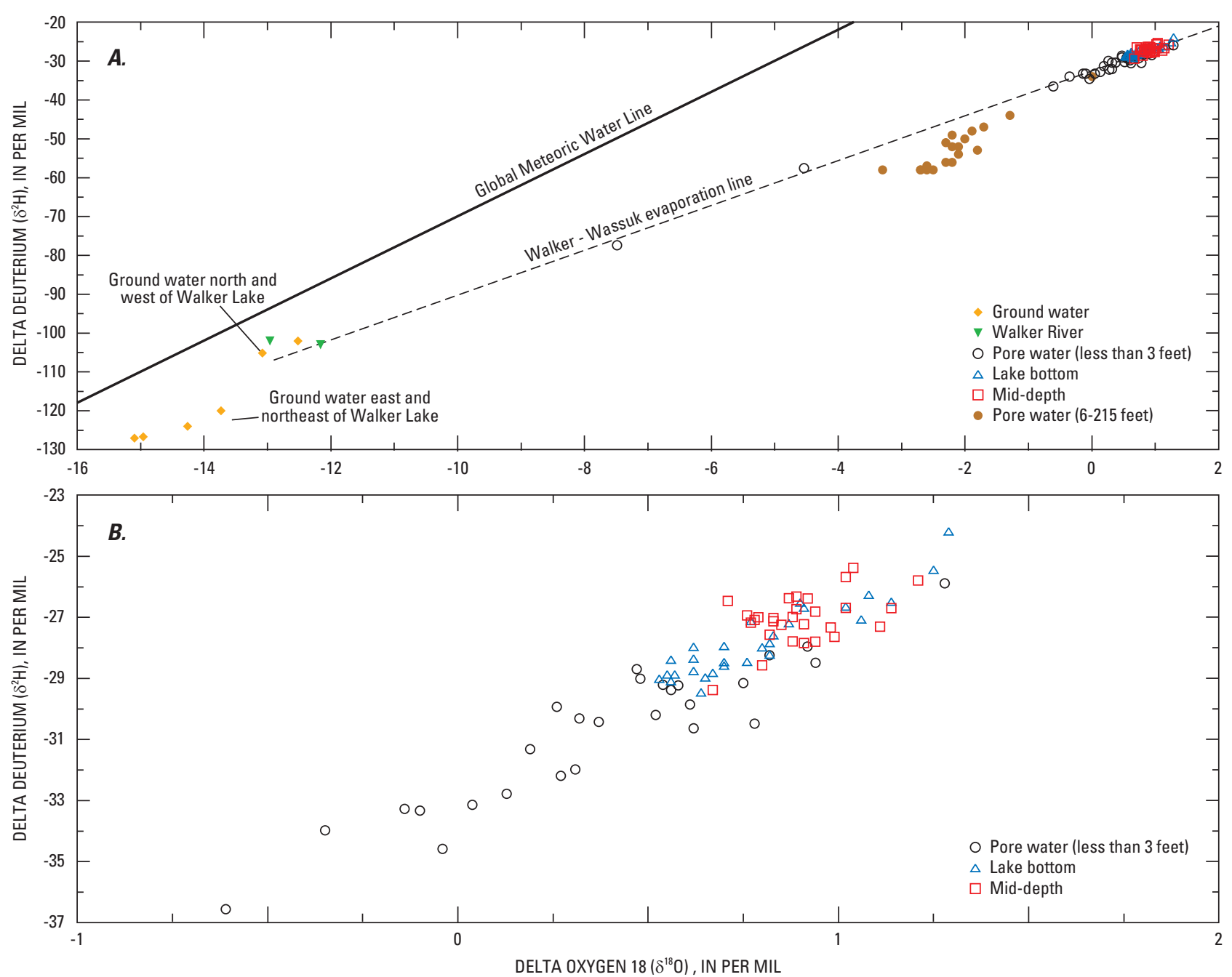

Figure 61. Deuterium compared with $\delta^{18} 0$ for $(A)$ all samples from Walker Lake, the Walker River, and nearby groundwater and $(B)$ selected pore-water, lake-bottom, and mid-depth samples from Walker Lake, Nevada. Selected samples are shown in $(B)$ to more easily compare different values for all but two core sites. Deep pore-water samples from 3 to 215 feet below the sediment-water interface were collected by Benson (1988).

The light isotopic composition of pore water likely is due to entrapment of water in sediments when Walker Lake was at a higher level during the modern-day climate and a wetter, cooler climate during the Pleistocene. $\delta^{18} \mathrm{O}$ in pore water has a significant Spearman rank correlation (-0.37) to depth below the sediment-water interface (fig. $62 \mathrm{~A}) . \delta^{18} \mathrm{O}$ values in shallow sediments (less than $3 \mathrm{ft}$ ) seem to be in two clusters with heavier values in the upper $1 \mathrm{ft}$ of sediment and lighter values below $1 \mathrm{ft}$ (fig. 62B $)$. Yuan and others (2006) found a similar difference in $\delta^{18} \mathrm{O}$ values in total inorganic carbon at a depth of $1 \mathrm{ft}$. Dating of sediments determined that the difference coincides with construction of reservoirs in the Walker River basin and the change in the hydrologic budget of Walker Lake.
The two shallow (less than $3 \mathrm{ft}$ ) pore waters that plot mid-way along the Walker-Wassuk evaporation line and are outliers in figure 62A are from the southern end of the Walker Lake and near the shoreline at Cottonwood Creek (fig. 45). These pore waters indicate groundwater discharge into the lake. Mass-balance calculations indicate the southern site has about 70 percent groundwater and the Cottonwood Creek site has 40 percent groundwater. No other sites had an isotopic indication of groundwater discharge, even though $5,200 \mathrm{acre}-\mathrm{ft} / \mathrm{yr}$ of subsurface discharge was estimated at the northern end of Walker Lake. 


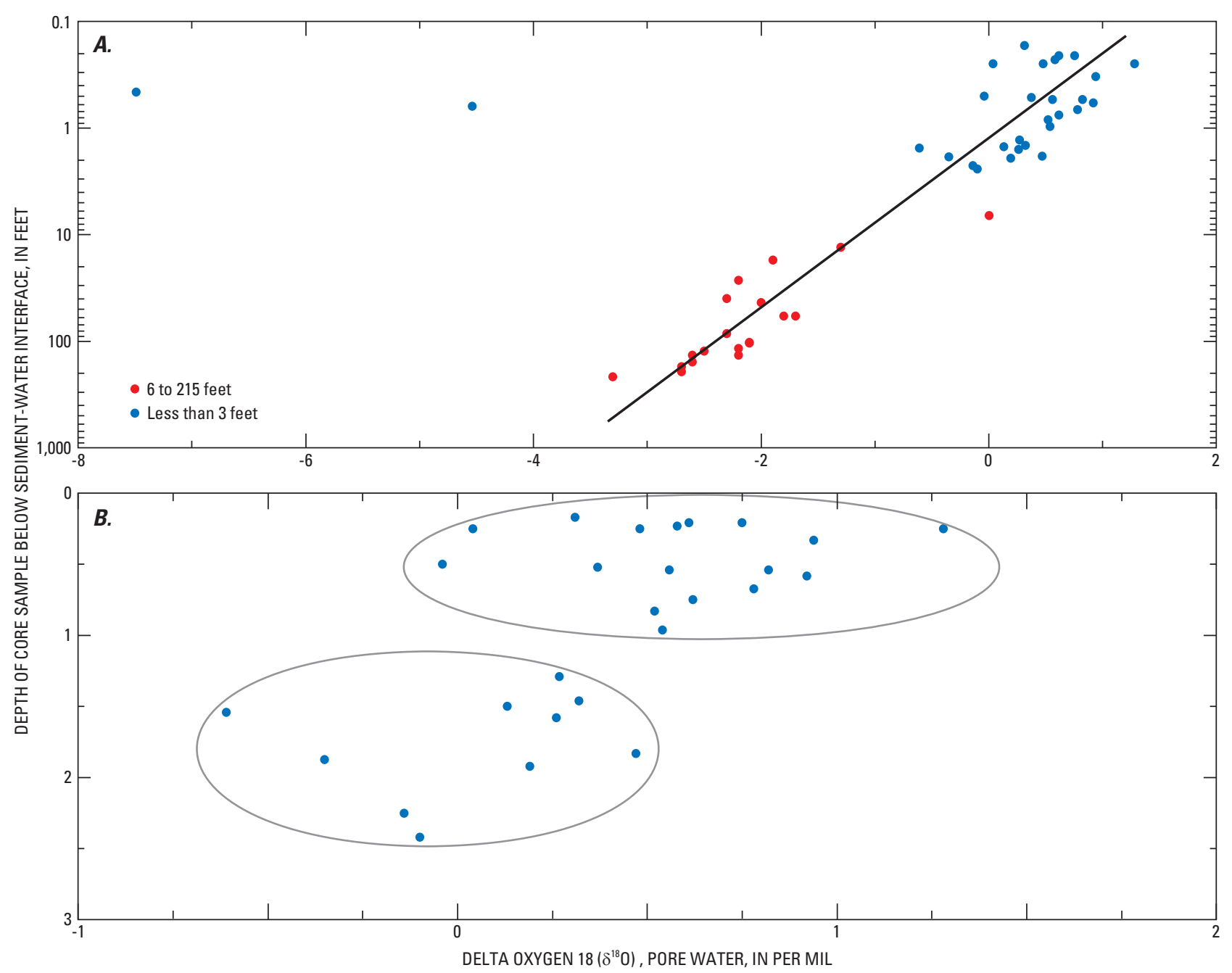

Figure 62. Depth compared with $\delta^{18} 0$ in pore water for $(A)$ shallow (less than 3 feet) and deep (6-215 feet) core samples and $(B)$ shallow core samples, Walker Lake, Nevada. Graph $(B)$ was plotted to more easily compare values for all but two shallow core samples. Deep samples were collected by Benson (1988).

\section{Summary}

The Walker River is the main source of inflow to Walker Lake, a closed-basin lake in west-central Nevada. The only outflow from Walker Lake is evaporation from the lake surface. Between 1882 and 2008, agricultural diversions resulted in a lake-level decline of more than $150 \mathrm{ft}$ and storage loss of 7,400,000 acre-ft. Evaporative concentration increased dissolved solids from 2,500 to $17,000 \mathrm{mg} / \mathrm{L}$. The increase in salinity threatens the survival of the Lahontan cutthroat trout, a native species listed as threatened under the Endangered Species Act. This report describes the hydrologic setting of the Walker River basin and a conceptual hydrologic model of the relations among streams, groundwater, and Walker Lake with emphasis on the lower Walker River basin from the Wabuska gage in northern Mason Valley to Hawthorne, Nev.
The Walker River basin is about 3,950 $\mathrm{mi}^{2}$ and straddles the California-Nevada border. Most streamflow in the basin originates as snowmelt in the Sierra Nevada that flows down the East and West Forks of the Walker River, which merge in southern Mason Valley. Outflow from Mason Valley and inflow to the lower Walker River basin is measured at the Wabuska gage. Three reservoirs in the basin store water that is used to irrigate mostly alfalfa in Smith Valley, Mason Valley, and the Reservation. Walker Lake is bounded on the west by the Wassuk Range and on the east by the Gillis Range.

Spring runoff from the Sierra Nevada and Wassuk Range typically begins in late April to early May and reaches its peak during late May to early June. Flows decline through June and early July and reach baseflow discharge in late July to early August. Except for occasional storms, discharge remains fairly steady until spring runoff the following year. 
Discharge at the Wabuska gage has not exceeded $2,800 \mathrm{ft}^{3} / \mathrm{s}$ since construction of reservoirs. The highest discharge rates occurred during spring runoff, but high flows also occur during winter from rain-on-snow events. Zero to less than $2 \mathrm{ft}^{3} / \mathrm{s}$ were measured during 1924, 1925, 1931, and 1977. In the Wassuk Range, the maximum discharge rate measured was $4.1 \mathrm{ft}^{3} / \mathrm{s}$ but $200 \mathrm{ft}^{3} / \mathrm{s}$ was estimated in one canyon. All streams in the Gillis Range are intermittent with measured discharge rates up to $2 \mathrm{ft}^{3} / \mathrm{s}$.

The 1971-2000 streamflow normal for the Wabuska gage is 138,000 acre-ft/yr, about 35 percent of the total streamflow in the drainage basin. About 65 percent of the streamflow is diverted, evaporated, transpired, or recharged upstream from the gage. Typically, there are 3 to 4 consecutive years of below average streamflow followed by 1 or 2 years of average or above average streamflow. The longest period of below average streamflow was 8 years (1987-94). This below average streamflow was followed by a 5-year period (199599) of above average streamflow, the longest wet period on record.

Specific conductance increases from $210 \mu \mathrm{S} / \mathrm{cm}$ in the West Fork and $280 \mu \mathrm{S} / \mathrm{cm}$ in the East Fork of the Walker River to $470 \mu \mathrm{S} / \mathrm{cm}$ at the Wabuska gage. Specific conductance does not change between Wabuska and Schurz, Nev., and increases to $870 \mu \mathrm{S} / \mathrm{cm}$ at the near Mouth gage due to groundwater discharge.

Soil permeability is high (10-20 ft/d) along the active channel of the lower Walker River and very high (20-30 ft/d) surrounding the lower Walker River, Walker Lake, and along the western slopes of the Gillis Range. Soils along the eastern Wassuk Range mostly are moderately permeable (5-10 ft/d). The predominance of moderately to very highly permeable soils in the lower Walker River basin would favor infiltration versus runoff.

The Wassuk and Gillis Ranges are comprised of consolidated-rock hydrogeologic units with low hydraulic conductivities but produce water where fractured.

Unconsolidated-sediment hydrogeologic units include fluvial deposits along the active channel of the lower Walker River, valley floors, alluvial slopes, and playas.

The upper $50 \mathrm{ft}$ of fluvial deposits along the Walker River are comprised of about 80 percent fine to coarse sand and gravel interbedded with sandy, silty clay. Individual coarsegrained strata average $8 \mathrm{ft}$ thick and clay strata average $4 \mathrm{ft}$ thick. The valley floor in the Schurz area has equal amounts of clay and coarse sediments that average $20 \mathrm{ft}$ thick. Sand and gravel likely are discontinuous strata throughout the valley floor. Thick clay strata likely were deposited in Lake Lahontan and have a high horizontal continuity, except where strata have been eroded by the Walker River. The valley floor in the Hawthorne area is about 70 percent coarse sediments and 30 percent clay. Coarse strata average $50 \mathrm{ft}$ thick and clay strata average $30 \mathrm{ft}$ thick. The exception is a topographic low southeast of Walker Lake that has about 85 percent clay with strata up to $286 \mathrm{ft}$ thick.
Alluvial slopes are poorly sorted sand, gravel, and boulders along the flanks of mountains that extend to fluvial deposits along the Walker River and into the western and eastern sides of Walker Lake. The only playa in the lower Walker River basin is at Double Spring, 6 mi east of Schurz, Nev. The playa is a flat surface of clay with a thin salt crust and salt grass growing near the spring and a flowing well.

Walker Lake is mostly clay interbedded with alluvialfan and deltaic deposits along the margins. Alluvial fans prograded up to $0.5 \mathrm{mi}$ into Walker Lake. Deltaic sediments extend almost $3 \mathrm{mi}$ south from the mouth of the Walker River. Alluvial, fluvial, and deltaic sediments likely were deposited onto the lake bed when Walker Lake was a shallow or desiccated playa during much of the Holocene. These sediments form a multilayered, confined aquifer system that could extend several miles from the eastern, western, and northern shorelines.

Depth to bedrock ranges from about 900 to $1,600 \mathrm{ft}$ near Double Spring, at least 1,500 ft south of Walker Lake, and about 2,000 ft north of Walker Lake. Semiconsolidated alluvium is assumed to have a hydraulic conductivity at least an order of magnitude less than saturated alluvium and does not readily transmit groundwater. The cross-sectional area of saturated alluvium that most groundwater flows through is about 460 acres near Double Spring, 150 acres south of Walker Lake, and 530 acres north of Walker Lake. The average hydraulic conductivity of the alluvial aquifer is from about 10 to $30 \mathrm{ft} / \mathrm{d}$ throughout the basin except immediately adjacent to the Walker River. Fluvial sediments along the Walker River have an average hydraulic conductivity of about $70 \mathrm{ft} / \mathrm{d}$. Subsurface flow was estimated to be 2,700 acre-ft/yr through Double Spring. Subsurface discharge to Walker Lake was estimated to be 4,400 acre-ft/yr from the south and $10,400 \mathrm{acre}-\mathrm{ft} / \mathrm{yr}$ from the north. Additional data are needed to determine groundwater-flow directions east of Double Spring and where subsurface flow discharges.

Dissolved-solids concentrations in two consolidated-rock aquifers were $457 \mathrm{mg} / \mathrm{L}$ and $591 \mathrm{mg} / \mathrm{L}$, close to the secondary drinking-water standard of $500 \mathrm{mg} / \mathrm{L}$. ${ }^{222} \mathrm{Rn}$ was $690 \mathrm{pCi} / \mathrm{L}$ in one well, which exceeds the proposed drinking-water standard of $300 \mathrm{pCi} / \mathrm{L}$. No other constituents that were measured exceeded primary or secondary drinking-water standards in consolidated-rock aquifers.

Dissolved-solids concentrations in the alluvial aquifer immediately adjacent to the Walker River ranged from 158 to $620 \mathrm{mg} / \mathrm{L}$. Away from the river, dissolved-solids concentrations in the alluvial aquifer typically were greater than $1,000 \mathrm{mg} / \mathrm{L}$. Most wells with greater than $1,000 \mathrm{mg} / \mathrm{L}$ dissolved solids exceeded secondary drinking-water standards of $250 \mathrm{mg} / \mathrm{L}$ for sulfate, $250 \mathrm{mg} / \mathrm{L}$ for chloride, and $2 \mathrm{mg} / \mathrm{L}$ for fluoride. Correlation among constituents and a $1 \mathrm{ft}$ thick stratum of salt indicate that high dissolved-solids concentrations mostly are from dissolution of salts. 
Three wells exceeded the secondary standard for iron $(0.3 \mathrm{mg} / \mathrm{L})$ and seven wells exceeded the secondary standard for manganese $(0.05 \mathrm{mg} / \mathrm{L})$. $\mathrm{pH}$ was 9.6 at the Double Spring well and 8.8 at the greasewood well, which exceeded the secondary drinking-water standard of 6.5-8.5 standard units. ${ }^{222} \mathrm{Rn}$ was $630 \mathrm{pCi} / \mathrm{L}$ and $800 \mathrm{pCi} / \mathrm{L}$ in two wells, which exceeded the proposed standard of $300 \mathrm{pCi} / \mathrm{L}$. No other constituents that were measured exceeded primary or secondary drinking-water standards.

Groundwater in the Walker River basin generally is less than $20 \mathrm{ft}$ deep along the Walker River and is less than $50 \mathrm{ft}$ under most of the valley floor from Smith Valley to Walker Lake. Depth to water increases from 100 to $300 \mathrm{ft}$ under the valley floor around Hawthorne and along the alluvium/ consolidated-rock contact in most of the basin. Groundwater deeper than $500 \mathrm{ft}$ is in Smith Valley, along the Desert and Terrill Mountains, the Gillis and Wassuk Ranges, and in the Whisky Flat area.

After the 2004 irrigation season, groundwater levels were an average of $9 \mathrm{ft}$ lower in Smith Valley and $4 \mathrm{ft}$ lower in Mason Valley compared to pre-irrigation levels. Groundwater levels recover between autumn and spring, but groundwater storage has declined steadily since 1960 . Total declines are as much as $60 \mathrm{ft}$ along the margins of the basins and $20 \mathrm{ft}$ near the Walker River.

Groundwater levels in the Schurz area have changed little during the past 50 years. In the Whisky Flat area south of Hawthorne, Nev., agricultural and municipal pumpage has lowered groundwater levels about $70 \mathrm{ft}$ since 1956. The decline in Walker Lake has caused the surrounding alluvial aquifer to drain. Groundwater levels along the 1882 shoreline have declined 30-40 ft. South of Walker Lake, groundwater levels have declined 10-15 ft since 1952.

Farming in Mason Valley began in 1859 and an extensive system of irrigation ditches was built from 1861 to 1865 . Walker Lake declined gradually from 1882 to the early 1920s when reservoirs were built on the Walker River. Since construction of the reservoirs, Walker Lake has had a steep, steady decline except during occasional wet periods. Comparisons to Mono Lake indicate that the decline is due primarily to diversions and the use of reservoirs to store and more efficiently manage water for irrigation.

The hydrology of the lower Walker River basin is considerably different than the upper basin. The upper basin consists of valleys separated by consolidated-rock mountains. The alluvial aquifer in each valley thins or pinches out at the downstream end, forcing most groundwater to discharge into the river where the river is gaged. The lower Walker River basin is one surface-water/groundwater system of losing and gaining reaches from the Wabuska gage to Walker Lake, which makes determining stream losses and the direction and amount of subsurface flow difficult.
Precipitation rates in the lower Walker River basin are low, soil permeability is high, and the Army Depot diverts streams in the Wassuk Range so runoff from the Wassuk and Gillis Ranges seldom reaches the Walker River or Walker Lake. Natural recharge occurs but is small compared to flow in the Walker River. Induced recharge occurs from infiltration of diverted water along unlined canals and ditches, infiltration of excess water applied to crops, and infiltration of septic effluent.

About 70 percent of the outflow from the lower Walker River basin is evaporation from Walker Lake. ET from natural and agricultural vegetation accounts for the remaining 30 percent of outflow. Outflow from aquifers occurs by ET from phreatophytes; pumpage from irrigation, municipal, and domestic wells; and subsurface flow to Walker Lake and alluvial aquifers east of Schurz, Nev.

Isotopic data indicate surface water and groundwater in the lower Walker River basin are from two sources that have evaporated. Data from the Walker River, groundwater along the Wassuk Range, and Walker Lake plot along one evaporation line. Groundwater along the Gillis Range and Calico Hills plots along a different evaporation line that indicates more intense evaporation and that these are not significant sources of water to Walker Lake.

Groundwater is present in consolidated rocks, but consolidated-rock aquifers store and transmit little water. Recharge occurs where mean annual precipitation is as little as 7-11 in. and forms groundwater divides that separate flow towards Walker Lake from flow towards adjacent valleys.

Groundwater in alluvial aquifers generally flows downvalley with flow towards the river in gaining reaches and away from the river in losing reaches. The Walker River is mostly gaining in Smith Valley and losing in Mason Valley. Additional data are needed in northern Mason Valley to define groundwater flow directions, quantify subsurface outflow, and characterize water-level response to pumping. In the lower Walker River basin, the river is losing for most of the reach between Wabuska and Cow Camp upstream from Weber Reservoir and gaining from Cow Camp to about 2 mi downstream from Weber Reservoir. Even though most of the reach between Wabuska and Cow Camp is losing, infiltration seems to be small and discharges back into the river downstream from Cow Camp. Additional data are needed to determine the flow direction when Weber Reservoir is maintained close to its maximum capacity of 10,700 acre-ft.

The Walker River is losing for most of the reach between the Little Dam gage and Lateral 2-A gage. Most irrigated fields around Schurz are adjacent to the losing reach. An estimated 6,000 acre-ft/yr of infiltration occurs along the losing reach. Stream infiltration and induced recharge has created a groundwater divide along the Walker River that separates groundwater that flows south towards Walker Lake from groundwater that flows east towards Double Spring and out of the Walker River Basin. 
Although most of the reach is gaining, streamflow can infiltrate between the Lateral 2-A gage and Walker Lake. Infiltration is greatest when streamflow follows an extended period with little flow. A maximum loss of 8,000 acre- $\mathrm{ft} / \mathrm{yr}$ was estimated for this reach when the 2005 spring runoff followed a 5-year drought.

Water-level contours and upward vertical gradients indicate Walker Lake is the final discharge point for groundwater in the lower Walker River basin. Isotopic data indicated groundwater discharge at the southern end of Walker Lake and near Cottonwood Creek on the west shore. No other sites indicated groundwater discharge, even though 5,200 acre-ft/yr of subsurface discharge was estimated at the northern end of Walker Lake.

\section{Acknowledgments}

This study would not have been possible without access to lands and wells granted by numerous private land owners in the basin. The authors also appreciate the cooperation, assistance, and information provided by: Jon McMasters and Gina Wachsmuth, Walker River Paiute Tribe; Kenneth Spooner, Walker River Irrigation District; James Shaw, Walker River Federal Watermaster; John Peterson and David Musselman, Hawthorne Army Ammunition Depot; and Elmer Bull, Nevada Department of Wildlife.

\section{References Cited}

Adams, K.D., 2004, Late Holocene diversion history of the Walker River-The take of a river with a split personality: Geological Society of America Abstracts with Programs, v. 36, no. 5, p. 499.

Adams, K.D., 2007, Late Holocene sedimentary environments and lake-level fluctuations at Walker Lake, Nevada, USA: Geological Society of America Bulletin, v. 119, no. 1-2, p. 126-139.

Allander, K.K., Smith, J.L., and Johnson, M.J., 2009, Evapotranspiration in the lower Walker River basin, west-central Nevada: U.S. Geological Survey Scientific Investigations Report 2009-5079, 62 p. Available at http:// pubs.usgs.gov/sir/2009/5079

Anning, D.W., and Konieczki, A.D., 2005, Classification of hydrogeologic areas and hydrogeologic flow systems in the basin and range physiographic province, southwestern United States: U.S. Geological Survey Professional Paper 1702, 44 p. Available at http://pubs.usgs.gov/pp/2005/ pp1702/
Benson, L.V., 1988, Preliminary paleolimnologic data for the Walker Lake subbasin, California and Nevada: U.S. Geological Survey Water-Resources Investigation Report 87-4258, 50 p.

Benson, L.V., Meyers, P.A., and Spencer, R.J., 1991, Change in the size of Walker Lake during the past 5000 years: Palaeogeography, Palaeoclimatology, Palaeoecology, v. 81, p. 189-214.

Benson, L.V., and Thompson, R.S., 1987, Lake-level variation in the Lahontan basin for the last 50,000 years: Quaternary Research, v. 28, p. 69-85.

Benson, Larry, Kashgarian, Michaele, Rye, Robert, Lund, Steve, Paillet, Fred, Smoot, Joseph, Kester, Cynthia, Mensing, Scott, Meko, Dave, and Linström, Susan, 2002, Holocene multidecadal and multicentennial droughts affecting northern California and Nevada: Quaternary Science Reviews, v. 21, p. 659-682.

Berger, D.L., Ponce, D.A., and Ross, W.C., 2001, Hydrogeologic framework of Antelope Valley and Bedell Flat, Washoe County, west-central Nevada: U.S. Geological Survey Water-Resources Investigations Report 01-4220, 11 p. Available at http://pubs.usgs.gov/wri/wri014220/

Blair, T.C., and McPherson, J.G., 1994, Historical adjustments by Walker River to lake-level fall over a tectonically tilted half-graben floor, Walker Lake Basin, Nevada: Sedimentary Geology, v. 92, p. 7-16.

Bonham, H.F., 1969, Geology and mineral deposits of Washoe and Storey Counties, Nevada: Nevada Bureau of Mines and Geology Bulletin 70, 140 p.

Bouwer, Herman, 1978, Groundwater Hydrology: New York McGraw-Hill, 480 p.

Bouwer, Herman, and Rice, R.C., 1976, A slug test for determining hydraulic conductivity of unconfined aquifers with completely or partially penetrating wells: Water Resources Research, v. 12, no. 3, p. 423-428.

Butler, J.J., Jr., Garnett, E.J., and Healey, J.M., 2003, Analysis of slug tests in formations of high hydraulic conductivity: Ground Water, v. 41. no. 5, p. 620-630.

California Division of Mines and Geology, 2000, GIS data for the geologic map of California: California Department of Conservation, Division of Mines and Geology, CD-ROM 2000-007.

Cardinalli, J.L., Roach, L.M., Rush, F.E., and Vasey, B.J., 1968, State of Nevada hydrographic areas, scale 1:500,000, in Rush, F.E., 1968, Index of hydrographic areas in Nevada: Nevada Division of Water Resources Information Report 6, $38 \mathrm{p}$. 
Cooper, H.H., Jr., Bredehoeft, J.D., and Papadopulos, I.S., 1967, Response of a finite-diameter well to an instantaneous charge of water: Water Resources Research, v. 3, no. 1, p. 263-269.

Cooper, J.J., and Koch, D.L, 1984, Limnology of a desertic terminal lake, Walker Lake, Nevada, U.S.A.: Hydrobiologia, v. 118, no. 3, p. 275-292.

Coplen, T.B., Herczeg, A.L., and Barnes, Chris, 2000, Isotope engineering-Using stable isotopes of the water molecule to solve practical problems, in Cook, P., and Herczeg, A.L., eds., Environmental tracers in subsurface hydrology: Boston, Kluwer Academic Publishers, p. 79-110.

Craig, Harmon, 1961, Isotopic variations in meteoric waters: Science, v. 133, p. 1702-1703.

Daly, Christopher, Neilson, R.P., and Phillips, D.L., 1994, A statistical-Topographic model for mapping climatological precipitation over mountainous terrain: Journal of Applied Meteorology, v. 33, no. 2, p. 140-158.

dePolo, C.M., Anderson, J.G., dePolo, D.M., and Price, J.G., 1997, Earthquake occurrence in the Reno-Carson City urban corridor: Seismological Research Letters, v. 68, no. 3, p. 401-412.

Domenico, P.A., and Schwartz, F.W., 1990, Physical and chemical hydrogeology: New York, John Wiley and Sons, $824 \mathrm{p}$.

Everett, D.E., and Rush, F.E., 1967, A brief appraisal of the water resources of the Walker Lake area, Mineral, Lyon, and Churchill Counties, Nevada: Nevada Department of Conversation and Natural Resources, Water ResourcesReconnaissance Series Report 40, 44 p.

Fetter, C.W., Jr., 1980, Applied hydrogeology: Columbus, Ohio, Charles E. Merrill Publishing Co., 488 p.

Foken, Thomas, 2008, The energy balance closure problemAn overview: Ecological Applications, v. 18, no. 6, p. 1351-1367.

Freeze, R.A., and Cherry, J.A., 1979, Groundwater: Englewood Cliffs, New Jersey, Prentice-Hall, 604 p.

Friedman, Irving, Harris, J.M., Smith, G.I., and Johnson, C.A., 2002, Stable isotope composition of waters in the Great Basin, United States-1. Air mass trajectories: Journal of Geophysical Research, v. 107, no. D19, 4400, doi:10.1029/2001JD000565.

Gallagher, T.K., 2005, Estimated annual ground-water pumpage, 1994-2003, Smith Valley and Mason Valley, Lyon County, Nevada: Nevada Division of Water Resources, accessed January 30, 2008, at http://water.nv.gov/scans/ Pumpage\%20Inventories/107-108\%20Smith-Mason\%20 Valley/107-108\%20Smith-Mason\%20Valley.pdf
GeoLytics, Inc., 2001, GeoLytics Census CD 2000 Short Form Blocks: E. Brunswick, N.J., GeoLytics, Inc., accessed April 27, 2009, at http://censuscd.com/USCensus,Census-2000Short-Form-Blocks,Products.asp

Gray, D.M, and Male, D.H., eds., 1981, Handbook of snowPrinciples, processes, management, and use: Pergamon Press, Inc., New York, 776 p.

Haeni, F.P., 1986, Application of seismic-refraction techniques to hydrologic studies: U.S. Geological Survey Open-File Report 84-746, 144 p.

Halford, K.J., 2006, MODOPTIM-A general optimization program for ground-water flow model calibration and ground-water management with MODFLOW: U.S. Geological Survey Scientific Investigations Report 20065009, 62 p. Available at http://pubs.usgs.gov/sir/2006/5009/

Halford, K.J., and Kuniansky, E.L., 2002, Documentation of spreadsheets for the analysis of aquifer-test and slug-test data: U.S. Geological Survey Open-File Report 02-197, 51 p. Available at http://pubs.usgs.gov/of/2002/ofr02197/

Harbaugh, A.W., and McDonald, M.G., 1996, Programmer's documentation for MODFLOW-96, an update to the U.S. Geological Survey modular finite-difference ground-water flow model: U.S. Geological Survey Open-File Report 96-486, $220 \mathrm{p}$.

Hardcastle, Jeff, 2006, Nevada county population estimates July 1, 1990 to July 1, 2006, including cities and towns: Nevada State Demographer's Office, University of Nevada, Reno, accessed October 2, 2007 at http://www.nsbdc.org/ what/data_statistics/demographer/pubs/docs/NVPopul06. pdf

Harding, S.T., 1965, Recent variations in the water supply of the Western Great Basin: University of CaliforniaBerkeley, Water Resources Center Archives, 226 p.

Helsel, D.R., and Hirsch, R.M., 1992, Statistical methods in water resources: New York, Elsevier Science Publishers, $522 \mathrm{p}$.

Horne, A.J., Roth, J.C., and Barratt, N.J., 1994, Walker Lake Nevada - State of the lake, 1992-94: Richmond, Calif., University of California, Berkeley and the Environmental Engineering and Health Sciences Laboratory, EEHSL Report 94-2, 85 p.

Horton, G.A., 1995, Walker River chronology-A chronological history of the Walker River and related water issues: Nevada Division of Water Resources, Department of Conservation and Natural Resources, Nevada River Chronology Publication Series, accessed October 5, 2007, at http://water.nv.gov/WaterPlanning/walker/wrchrono.cfm 
Hostetler, S.W., and Benson, L.V., 1994, Stable isotopes of oxygen and hydrogen in the Truckee River-Pyramid Lake surface-water system. 2. A predictive model of ${ }^{18} \mathrm{O}$ and ${ }^{2} \mathrm{H}$ in Pyramid Lake: Journal of Limnology and Oceanography, v. 39, no. 2, p. 356-364.

Houghton, J.G., Sakamoto, C.M., and Gifford, R.M., 1975, Nevada's climate and weather: Nevada Bureau of Mines and Geology Special Publication 2, 78 p.

Huffman and Carpenter, Inc., 2007, Technical findings for 2007 irrigation season flow monitoring on the lower Walker River: Reno, Nev., Huffman and Carpenter, Inc., Wetland Regulatory and Hydrologic Consultants, 4 p., 2 attachments.

Huxel, C.J., Jr., and Harris, E.E., 1969, Water resources and development in Mason Valley, Lyon and Mineral Counties, Nevada, 1948-65: Nevada Division of Water Resources Bulletin 38, 77 p.

Katzer, T.L., and Harmsen, Lynn, 1973, Bathymetric reconnaissance of Weber Reservoir, Mineral County, Nevada: Nevada Division of Water Resources Water Resources-Information Series Report 15, 1 plate.

Kennedy, E.J., 1983, Computation of continuous records of streamflow: U.S. Geological Survey Techniques of WaterResource Investigation, book 3, chap. A13, 53 p. Available at http://pubs.usgs.gov/twri/twri3-a13/

Link, M.H., Roberts, M.T., and Newton, M.S., 1985, Walker Lake Basin, Nevada - An example of Late Tertiary (?) to recent sedimentation in a basin adjacent to an active strike-slip fault, in Biddle, K.T., and Christie-Blink, N., eds., Strike-slip deformation, basin formation, and sedimentation: Tulsa, Society of Economic Paleontologists and Mineralogists, p. 105-125.

Lopes, T.J., 2005, Science to sustain terminal lakes-The Walker River basin study: U.S. Geological Survey Fact Sheet 2005-3124, 2 p.

Lopes, T.J., 2006, Quality of Nevada's aquifers and their susceptibility to contamination, 1990-2004: U.S. Geological Survey Scientific Investigations Report 20065127, 52 p. Available at http://pubs.usgs.gov/sir/2006/5127/

Lopes, T.J., and Allander, K.K., 2009, Water budgets of the Walker River basin and Walker Lake, California and Nevada: U.S. Geological Survey Scientific Investigations Report 2009-5157, 44 p. Available at http://pubs.usgs.gov/ $\underline{\text { sir/2009/5157 }}$

Lopes, T.J., and Evetts, D.M., 2004, Ground-water pumpage and artificial recharge estimates for calendar year 2000 and average annual natural recharge and interbasin flow by hydrographic area, Nevada: U.S. Geological Survey Scientific Investigations Report 2004-5239, 81 p. Available at http://pubs.usgs.gov/sir/2004/5239/
Lopes, T.J., and Medina, R.L., 2007, Precipitation zones of west-central Nevada: Journal of the Nevada Water Resources Association, v. 4, no. 2, p. 1-19.

Lopes, T.J., and Smith, J.L., 2007, Bathymetry of Walker Lake, west-central Nevada: U.S. Geological Survey Scientific Investigations Report 2007-5012, 26 p. Available at http://pubs.usgs.gov/sir/2007/5012/

Maurer, D.K., Lopes, T.J., Medina, R.L., and Smith, J.L., 2004, Hydrogeology and hydrologic landscape regions of Nevada: U.S. Geological Survey Scientific Investigations Report 2004-5131, 35 p. Available at http://pubs.usgs.gov/ $\underline{\text { sir/2004/5131/ }}$

McDonald, M.G., and Harbaugh, A.W., 1988, A modular three-dimensional finite-difference ground-water flow model: U.S. Geological Survey Techniques of WaterResources Investigations, book 6, chap. A1, 576 p. Available at http://pubs.usgs.gov/twri/twri6a1/

Milne, Wendy, 1987, A comparison of reconstructed lake-level records since the mid-1800's of some Great Basin lakes: Golden, Colorado School of Mines, Master's Thesis, 207 p.

Nevada Department of Wildlife, 2008, Mason Valley Wildlife Management Area: Reno, Nev., Habitat and Conservation Bureaus, 2 p., accessed April 27, 2009, at http://www.ndow. org/about/pubs/wma/wma_mason.pdf

Pahl, Randy, 1997, Walker River basin gaging stationsSummary of historic and estimated streamflow, reservoir \& lake level gaging station records: Nevada Water Basin Information and Chronology Series, Nevada Division of Water Planning, Department of Conservation and Natural Resources, 19 p. plus appendixes.

Pahl, Randy, 2000a, Walker River Basin irrigation diversions - Summary of historic surface water irrigation diversions: Nevada Water Basin Information and Chronology Series, Nevada Division of Water Planning, Department of Conservation and Natural Resources, $15 \mathrm{p}$.

Pahl, Randy, 2000b, Walker River Basin surface water budget-Summary of basin surface water inflows and outflows (1926-95): Nevada Water Basin Information and Chronology Series, Nevada Division of Water Planning, Department of Conservation and Natural Resources, 32 p.

Pakiser, L.C., and Black, R.A., 1957, Exploring for ancient channels with the refraction seismograph: Geophysics, v. 22, no. 1, p. 32-47.

Reheis, Marith, 1999, Extent of Pleistocene lakes in the western Great Basin: U.S. Geological Survey Miscellaneous Field Studies Map MF-2323, available at http://pubs.usgs. gov/mf/1999/mf-2323/ 
Reheis, M.C., Sarna-Wojcicki, A.M., Reynolds, R.L., Repenning, C.A., and Mifflin, M.D., 2002, Pliocene to Middle Pleistocene Lakes in the Western Great BasinAges and Connections, in Hershler, Robert, Madsen, D.B, and Currey, D.R., eds., Great Basin aquatic systems history: Smithsonian contributions to the earth sciences, no. 33, Smithsonian Institution Press, Washington, D.C., 405 p.

Rimrock Geophysics, Inc., 1995, User's guide to SIPT2 V-4.1: Lakewood, Colo., Rimrock Geophysics, Inc., 56 p.

Rush, F.E., 1968, Index of hydrographic areas in Nevada: Nevada Division of Water Resources, Water ResourcesInformation Series Report 6, 38 p.

Rush, F.E., 1970, Hydrologic regimen of Walker Lake, Mineral County, Nevada: U.S. Geological Survey Hydrologic Investigations Atlas HA-415, scale 1:62,500.

Rush, F.E., and Schroer, C.V., 1976, Geohydrology of Smith Valley, Nevada, with special reference to the water-use period 1953-72: Nevada Division of Water Resources, Water-Resources Bulletin no. 43, 95 p.

Russell, I.C., 1885, Geologic history of Lake Lahontan-A Quaternary lake in northwestern Nevada: U.S. Geological Survey Monograph 11, 288 p.

Sapp, Claude, 2007, Geothermal power generation and biodiesel production in Wabuska, Nevada: Geothermal Heat Center Bulletin, v. 28. no. 1, p. 9-12, accessed December 10, 2008, at http://geoheat.oit.edu/bulletin/bull28-1/art4.pdf

Schaefer, D.H., 1980, An appraisal of the water resources of the Walker River Indian Reservation, Nevada: U.S. Geological Survey Open-File Report 80-427, 65 p.

Smith, G.I., Friedman, Irving, Veronda, Guida, and Johnson, C.A., 2002, Stable isotope compositions in the Great Basin, United States - 3. Comparison of groundwaters with modern precipitation: Journal of Geophysical Research, v. 107, no. D19, 4402, doi:10.1029/2001JD000567, 2002.

Stewart, J.H., 1988, Tectonics of the Walker Lane Belt, Western Great Basin, in Ernst, W.G., ed., Metamorphism and crustal evolution of the Western United States: Rubey Volume VII, Prentice Hall, p. 683-713.

Theis, C.V., 1935, The relation between the lowering of the piezometric surface and the rate and duration of discharge of a well using ground water storage: Transactions of the American Geophysical Union, v. 16, p. 519-524.

Thomas, J.M., 1995, Water budget and salinity of Walker Lake, western Nevada: U.S. Geological Survey Fact Sheet FS-115-95, 4 p.

Thomas, K.A., and Hess, G.W., 1997, Flood of January 1997 in the Walker River Basin, California and Nevada: U.S. Geological Survey Fact Sheet FS-182-97, 2 p.
U.S. Environmental Protection Agency, 2008a, Drinking water contaminants: U.S. Environmental Protection Agency, accessed January 31, 2008, at http://www.epa.gov/ safewater/contaminants/index.html

U.S. Environmental Protection Agency, 2008b, Drinking water contaminants: U.S. Environmental Protection Agency, accessed January 31, 2008, at http:/www.epa.gov/ safewater/radon/proposal.html

U.S. Geological Survey, 2006a, Quaternary fault and fold database of the United States: U.S. Geological Survey, accessed May 29, 2008, at http://earthquake.usgs.gov/ regional/qfaults/

U.S. Geological Survey, 2006b, Collection of water samples (ver. 2.0): U.S. Geological Survey Techniques of WaterResources Investigations, book 9, chap. A4, revised 2006, Wilde, F.D., ed., 166 p. Available at http://pubs.water.usgs. gov/twri9A4/

U.S. Geological Survey, 2007, Water-resources data for the United States, water year 2007: U.S. Geological Survey database. Available at http://wdr.water.usgs.gov/wy2007/ search.jsp

Van Denburgh, A.S., Goerlitz, D.F., and Godsy, E.M., 1996, Depletion of nitrogen-bearing explosives wastes in a shallow ground-water plume near Hawthorne, Nevada, in Morganwalp, D.W., and Aronson, D.A., eds., U.S. Geological Survey Toxic Substances Hydrology ProgramProceedings of the technical meeting; Colorado Springs, Colo., September 20-24, 1993, v. 2, p. 895-904.

Wesnonsky, S.G., 2005, The San Andreas and Walker Lane fault systems, western North America-Transpression, transtension, cumulative slip, and the structural evolution of a major transform plate boundary: Journal of Structural Geology, v. 27, p. 1505-1515.

Wilde, F.D., Radtke, D.B., Gibs, Jacob, and Iwatsubo, R.T., eds., 2004, Processing of water samples (ver. 2.1): U.S. Geological Survey Techniques of Water-Resources Investigations, book 9, chap. 5, 130 p. Available at http:// pubs.water.usgs.gov/twri9A5/ (Separate updates for 5.6.1.F, "Wastewater, pharmaceutical, and antibiotic compounds," 5.6.1.F, "Arsenic speciation," and 5.6.4.B, "Low-level mercury" are provided on the web page).

Wolff, R.G., 1982, Physical properties of rocks-Porosity, permeability, distribution coefficients, and dispersivity: U.S. Geological Survey Open-File Report 82-166, 118 p.

Yuan, Fasong, Linsley, B.K., and Howe, S.S., 2006, Evaluating sedimentary geochemical lake-level tracers in Walker Lake, Nevada, over the last 200 years: Journal of Paleolimnology, v. 36, p. 37-54. 
This page intentionally left blank. 
Publishing support provided by the U.S. Geological Survey

Publishing Network, Tacoma Publishing Service Center

For more information concerning the research in this report, contact the

Director, Nevada Water Science Center

U.S. Geological Survey

2730 N. Deer Run Road

Carson City, Nevada 89701

http://nevada.usgs.gov/water/index.htm 
